\title{
Elemental abundances and classification of carbon-enhanced metal-poor stars $\star, \star \star$
}

\author{
D. M. Allen ${ }^{1, \star \star \star}$, S. G. Ryan ${ }^{2, \star \star \star \star}$, S. Rossi ${ }^{1}$, T. C. Beers ${ }^{4, \dagger}$, and S. A. Tsangarides ${ }^{\star \star \star \star}$ \\ ${ }^{1}$ Instituto de Astronomia, Geofísica e Ciências Atmosféricas, Universidade de São Paulo, rua do Matão 1226, 05508-900 São Paulo, \\ Brazil \\ e-mail: [dimallen;rossi]@astro.iag.usp.br \\ 2 Centre for Astrophysics Research, STRI and School of Physics, Astronomy and Mathematics, University of Hertfordshire, Hatfield, \\ UK \\ e-mail: s.g.ryan@herts.ac.uk \\ 3 National Optical Astronomy Observatory, 950 N. Cherry Avenue, Tucson, AZ 85719, USA \\ e-mail: beers@noao.edu
}

Received 19 August 2010 / Accepted 24 August 2012

\begin{abstract}
We present a detailed study of carbon-enhanced metal-poor (CEMP) stars, based on high-resolution spectroscopic observations of a sample of 18 stars. The stellar spectra for this sample were obtained at the $4.2 \mathrm{~m}$ William Herschel Telescope in 2001 and 2002 , using the Utrecht Echelle Spectrograph, at a resolving power $R \sim 52000$ and $S / N \sim 40$, covering the wavelength range $\lambda \lambda 3700-5700 \AA$. The atmospheric parameters determined for this sample indicate temperatures ranging from $4750 \mathrm{~K}$ to $7100 \mathrm{~K}, \log g$ from 1.5 to 4.3 , and metallicities $-3.0 \leq[\mathrm{Fe} / \mathrm{H}] \leq-1.7$. Elemental abundances for $\mathrm{C}, \mathrm{Na}, \mathrm{Mg}, \mathrm{Sc}, \mathrm{Ti}, \mathrm{Cr}, \mathrm{Cu}, \mathrm{Zn}, \mathrm{Sr}, \mathrm{Y}, \mathrm{Zr}, \mathrm{Ba}, \mathrm{La}, \mathrm{Ce}, \mathrm{Nd}, \mathrm{Sm}, \mathrm{Eu}, \mathrm{Gd}$, Dy are determined. Abundances for an additional 109 stars were taken from the literature and combined with the data of our sample. The literature sample reveals a lack of reliable abundance estimates for species that might be associated with the r-process elements for about $67 \%$ of CEMP stars, preventing a complete understanding of this class of stars, since $[\mathrm{Ba} / \mathrm{Eu}]$ ratios are used to classify them. Although eight stars in our observed sample are also found in the literature sample, Eu abundances or limits are determined for four of these stars for the first time. From the observed correlations between $\mathrm{C}, \mathrm{Ba}$, and Eu, we argue that the CEMP-r/s class has the same astronomical origin as CEMP-s stars, highlighting the need for a more complete understanding of Eu production.
\end{abstract}

Key words. stars: abundances - stars: atmospheres - stars: chemically peculiar - stars: carbon

\section{Introduction}

Over the course of the past few decades, several groups have actively studied stars identified as very metal poor by two major objective-prism surveys, the HK Survey of Beers and colleagues (Beers et al. 1992, 1985) and the Hamburg/ESO survey of Christlieb and colleagues (Christlieb et al. 2008). A large fraction, at least $20 \%$, of stars with metallicities $[\mathrm{Fe} / \mathrm{H}]<-2.0$ have been shown to exhibit large over-abundances of carbon relative to iron, $[\mathrm{C} / \mathrm{Fe}]>+1.0$ (Rossi et al. 1999; Lucatello et al. 2006; Marsteller et al. 2009; Carollo et al. 2012). The fraction of so-called carbon-enhanced metal-poor (CEMP) stars rises to $30 \%$ for $[\mathrm{Fe} / \mathrm{H}]<-3.0,40 \%$ for $[\mathrm{Fe} / \mathrm{H}]<-3.5$,

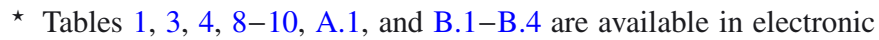
form at http://www . aanda.org

$\star \star$ Full Tables 2, 5, and 7 are only available at the CDS via anonymous ftp to cdsarc.u-strasbg.fr $(130.79 .128 .5)$ or via

http://cdsarc.u-strasbg.fr/viz-bin/qcat?]/A+A/548/A34

$\star \star \star$ Current address: Escola de Artes, Ciências e Humanidades, USP,

Av. Arlindo Bettio, 1000, 03828-000 São Paulo, SP, Brazil.

$\star \star \star \star$ Previous address: The Open University, Walton Hall, Milton Keynes, UK; e-mail: tsangarides.stelios@gmail.com

Previous address: Dept. of Physics \& Astronomy and JINA: Joint Institute for Nuclear Astrophysics, Michigan State University, E. Lansing, MI 48824, USA. and $75 \%$ for $[\mathrm{Fe} / \mathrm{H}]<-4.0$ (Christlieb et al. 2002; Beers \& Christlieb 2005; Frebel et al. 2005; Norris et al. 2007; Carollo et al. 2012). The CEMP fraction for ultra metal-poor stars with $[\mathrm{Fe} / \mathrm{H}]<-4.0$ was $100 \%$ until the recent report by Caffau et al. (2011) of a new hyper metal-poor star (SDSS J102915+172927, with $[\mathrm{Fe} / \mathrm{H}]=-5.0)$ that differs from the other three known ultra and hyper metal-poor stars in that it does not exhibit carbon enhancement.

The diversity of chemical compositions seen among the CEMP stars, together with their very low metallicities, provides insights into the early stages of Galactic star formation, stellar evolution, and galaxy formation. Several scenarios have been proposed to explain the likely multiple origins of the high carbon enhancements shown by these stars, but uncertainties remain. Observations of the neutron-capture elements (those produced by the s-process and r-process) can help shed light on these questions, given that their production is related to different timescales, and almost certainly different astrophysical sites. In this regard, it is of importance that Hansen et al. (2011) have recently reported the results of a four-year radial velocity monitoring project for moderately and highly r-process-enhanced metal-poor stars (classes r-I and r-II according to the nomenclature of Beers \& Christlieb 2005), and demonstrated that the binary fraction of these stars is no different than found for other low-metallicity halo stars (about 20\%). In comparison, 
s-process-enhanced CEMP stars possess elevated binary fractions, possibly 100\%, (Lucatello et al. 2005). This result immediately suggests that the r-process enhancement phenomenon does not apparently require pollution from a companion star, and underscores the likelihood that the astrophysical sites of the r-process and s-process are decoupled from one another.

Barium and europium are often taken as representatives of the s- and the r-processes, respectively, according to the dominance of these processes on their production in Solar System material. According to Arlandini et al. (1999), in the Solar System, the main component of the s-process contributes $\approx 82 \%$ of the $\mathrm{Ba}$, whereas $\approx 18 \%$ is due to the r-process. By way of contrast, while $6 \%$ of Eu in solar-composition material results from the s-process, the r-process accounts for the production of essentially all the rest (94\%). Barium abundances are easily measured for very metal-poor stars, since its strongest lines are unsaturated, which is often not the case for stars with higher metallicities. Although the lines of $\mathrm{Eu}$ are weaker than those of $\mathrm{Ba}$, $\mathrm{Eu}$ abundances nevertheless are often readily measurable in optical spectra of metal-poor stars. Hence, $\mathrm{Ba}$ and $\mathrm{Eu}$ are useful and accessible indicators of the s- and r-processes.

The r-process is believed to occur in the final evolutionary stages of massive stars $\left(M>8 M_{\odot}\right)$, whereas the main component of the s-process is believed to occur in thermally-pulsing asymptotic giant-branch (TP-AGB) stars of low $\left(1-3 M_{\odot}\right)$ to intermediate (4-8 $M_{\odot}$ ) masses (e.g., Herwig 2005). As the timescale for stars to reach the SN II (type II supernova) stage $\left(t<10^{8} \mathrm{yr}\right)$ is less than that for stars to reach the AGB phase, it is usual to investigate the s-process contribution by analyzing the $[\mathrm{Ba} / \mathrm{Eu}]$ abundance ratio. A value of $[\mathrm{Ba} / \mathrm{Eu}] \sim-0.70$, found in metal-poor stars, indicates Ba production only by the r-process (Mashonkina \& Gehren 2001). When the s-process begins to produce $\mathrm{Ba}$, an increase in its abundance relative to $\mathrm{Eu}$ can be seen, ultimately reaching values compatible with the solar $[\mathrm{Ba} / \mathrm{Eu}]$ ratio (Travaglio et al. 1999).

Beers \& Christlieb (2005) have used the Ba and Eu abundance signatures to classify CEMP stars into several broad categories: CEMP-s, stars that exhibit large over-abundances of s-process elements, with $[\mathrm{Ba} / \mathrm{Fe}]>+1$ and $[\mathrm{Ba} / \mathrm{Eu}]>+0.5$, and account for some $80 \%$ of all studied CEMP stars according to Aoki et al. (2007); CEMP-r, stars exhibiting over-abundances of r-process elements and $[\mathrm{Ba} / \mathrm{Eu}]<0$ (McWilliam et al. 1995; Norris et al. 1997; Sneden et al. 2003; Honda et al. 2004; Barklem et al. 2005; Cohen et al. 2006); CEMP-r/s, stars with $0<[\mathrm{Ba} / \mathrm{Eu}] \lesssim+0.5$, and exhibiting both $\mathrm{r}$ - and s-process enhancements (Hill et al. 2000; Wanajo et al. 2006); and CEMP-no, stars that exhibit no over-abundances of neutron-capture elements ([Ba/Fe] < 0; e.g., Aoki et al. 2007; Ito et al. 2009).

There has been some discussion in the literature concerning the relationship of the CEMP-r/s class to the CEMP-s class. Tsangarides (2005) pointed out that the $[\mathrm{Ba} / \mathrm{Eu}]$ ratios for some stars classified previously as CEMP-s are similar to those for stars classified as CEMP-r/s, and called into question whether the hybrid $\mathrm{r} / \mathrm{s}$ classification is strictly necessary. He also speculated that the progenitors of the CEMP-s and CEMP-r/s class may even be one and the same (TP-AGB stars). Unfortunately, for many known CEMP stars, measurements of Eu abundances are not available, and instead $\mathrm{Ba}$ is sometimes used as an $\mathrm{r}$-process indicator, even though it is produced in both the $\mathrm{r}$ - and s-processes. For further discussion of these issues, see the recent paper by Bisterzo et al. (2010).

In this paper we seek a better understanding of the possible differences between stars classified as CEMP-s and CEMP-r/s, by expanding the numbers of CEMP stars with available
Eu abundance measurements. We also reconsider the interpretation of previously published high-resolution abundance determinations for CEMP stars. The paper is organized as follows. Section 2 presents the data and describes the determination of the stellar atmospheric parameters. Section 3 describes the abundance and uncertainty determinations. In Sect. 4 our results are discussed, as well as those obtained from inspection of data from the literature. Our conclusions are drawn in Sect. 5.

\section{Observations and stellar parameters}

Twenty-six candidate CEMP stars, listed in Table 1, were selected from the HK survey of Beers et al. (1985), and from more recent unpublished follow-up medium-resolution extensions of that programme, according to two criteria: an HK-survey metallicity estimate $[\mathrm{Fe} / \mathrm{H}] \lesssim-1.5$, and a carbon-enhancement index $\mathrm{CEN} \gtrsim 0.5$, implying a $\mathrm{CH}$ G-band strength more than $1.5 \times$ the median value at that temperature and metallicity. The CEN index is defined as $\left(\mathrm{GP}_{*}-\mathrm{GP}_{\mathrm{M}}\right) / \mathrm{GP}_{\mathrm{M}}$, where GP is the Beers et al. (1985, their Table 1) CH G-band index, and the subscripts "*", and " $M$ " refer to a particular star and the median for stars of that temperature and metallicity. The notes column identifies stars which our analysis ultimately showed were not genuine CEMP stars (Sect. 3.1).

Twenty-three stellar spectra were observed by $\mathrm{SAT}^{1}$ and $\mathrm{SGR}^{2}$ at the $4.2 \mathrm{~m}$ William Herschel Telescope (WHT) in August 2001 and April 2002, using the Utrecht Echelle Spectrograph (UES), with a resolving power of $R \sim 52000$ and signal-to-noise ratio $(\mathrm{S} / \mathrm{N}) \sim 40$ per $0.026 \AA$ pixel. The spectra cover the wavelength range $\lambda \lambda 3500-5700 \AA$. Three additional high-resolution spectra were obtained by SGR and John Norris on the $3.9 \mathrm{~m}$ Anglo-Australian Telescope in September 2000, using the UCL Echelle Spectrograph (UCLES). The spectra were reduced by SAT with IRAF ${ }^{3}$, using standard procedures. Because of the large number of spectra taken, the reduced data were analysed in two subgroups, one by $\mathrm{DMA}^{4}$ (12 stars) and the other by SAT (14 stars). The approaches were similar in concept, although they differed slightly in the details.

Photometric UBVRI observations of stars from the SAT subsample (see Table 1) were obtained by $\mathrm{TCB}^{5}$ on the WisconsinIndiana-Yale-NOAO (WIYN) Observatory $0.9 \mathrm{~m}$ telescope on Kitt Peak, and at the ESO/Danish $1.5 \mathrm{~m}$ telescope at La Silla (Chile), and by TCB and Don Terndrup on the MDM Observatory $2.5 \mathrm{~m}$ telescope, also on Kitt Peak (Beers et al. 1994, 2007). Near-IR JHK photometry was taken for the $26 \mathrm{ob}-$ jects from the interim data release of the 2MASS point source catalogue (2MASS 2003; Skrutskie et al. 1997).

Calculation of even a single model atmosphere is a computationally intensive task. Stellar parameters, such as effective temperature $\left(T_{\text {eff }}\right)$, surface gravity $(\log g)$, and metallicity $([\mathrm{Fe} / \mathrm{H}])$, are usually required a priori. However, these are quantities to be determined using the model atmosphere during the analysis; thus, we can only arrive at an appropriate set of parameters

\footnotetext{
Stelios A. Tsangarides.

Sean G. Ryan.

3 IRAF is distributed by the National Optical Astronomy Observatory, which is operated by the Association of Universities for Research in Astronomy (AURA) under cooperative agreement with the US National Science Foundation.

4 Dinah M. Allen.

5 Timothy C. Beers.
} 
and model atmosphere by iteration. This procedure is impractical if a fresh model is to be obtained at every step, given the computational demands of its calculation. Hence, most groups evaluate a grid of several model atmospheres to begin with, in which each model possesses a different set of input atmospheric parameters. One then interpolates between models of this grid, in order to more quickly compute new models at a desired set of atmospheric parameters. Inherent in this interpolation is the assumption that the physics of each grid model can be scaled to nearby atmospheric parameters.

\subsection{The DMA subsample}

The adopted model atmospheres were computed with the latest version of the ATLAS9 code, initially developed by Kurucz (1992, 1993), and subsequently updated by Castelli et al. (1997) and Castelli \& Kurucz (2004), with enhanced $\alpha$-element abundances, but no $\mathrm{C}$ - or $\mathrm{N}$-enhancement. The current version uses an improved opacity distribution function, where the solar abundances, TiO lines, and some atomic and molecular constants were replaced.

Before determining the photometric temperatures, an initial value for interstellar reddening was estimated. Since there are no available Hipparcos parallaxes for the stars in our sample, the first values for the absolute magnitude $\left(M_{V}\right)$ of each star were taken from the colour-magnitude diagrams (CMDs, $\left.M_{V}\right)$ vs. $B-V)$ given by Green et al. (1987) and Lejeune et al. (1998). These diagrams usually provide two $M_{V}$ values for each $B-V$, according to the evolutionary state of the star, so the first value to be used was chosen arbitrarily. This absolute magnitude was then used to estimate the first value for the distance; that, together with the Galactic coordinates in Table 1, were used to calculate the first value for the visual extinction, $A_{V}$, following Hakkila et al. (1997). Then, the photometric temperatures were calculated using the colour-temperature calibrations of Alonso et al. (1996a, 1999), considering $[\mathrm{Fe} / \mathrm{H}]=-1.5,-2$, and -2.5 . These authors use accurate stellar-diameter effective temperatures from the literature to calculate temperatures for objects with observed multiple pass-band colours, using the infrared flux-method (IRFM). Alonso et al. (1996a, 1999) use the Johnson system for UBVRI and TCS (Telescopio Carlos Sánchez) for $J H K L M N$, so before determining the temperatures, the colours were transformed according to Bessell (1979), Alonso et al. (1998), and Carpenter (2001). The mean value for the temperature derived from $B-V, V-R, V-I$, and colours derived from 2MASS magnitudes is the first value for the temperature used to create the model atmosphere. For some stars, such as BS 16077-077, temperatures derived from the $B-V$ and $V-K$ colours are very low compared to those from other colours, so they were neglected. Bolometric corrections $B C(V)$ were determined according to Alonso et al. (1995) or Alonso et al. (1999), depending on the more probable evolutionary stage of the star, as estimated from the CMD. With the initial values of temperature and extinction-corrected $(B-V)_{\mathrm{o}}$, the first input for the mass was taken from the Yonsei-Yale isochrones $\left(\mathrm{Y}^{2}\right)$, described by Yi et al. (2001), Kim et al. (2002), Yi et al. (2003) and Demarque et al. (2004). Then, the first estimate for $\log g$ (and its error) were taken from the relations:

$$
\begin{aligned}
\log \left(\frac{g_{*}}{g_{\odot}}\right)= & \log \left(\frac{M_{*}}{M_{\odot}}\right)+4 \log \left(\frac{T_{\text {eff } *}}{T_{\text {eff } \odot}}\right)+0.4 V_{\circ} \\
& +0.4 B C(V)+2 \log \frac{1}{D}+0.1
\end{aligned}
$$

Table 2. Iron lines for the DMA subsample.

\begin{tabular}{lcccccccc}
\hline \hline Ion & $\lambda(\AA)$ & $\chi$ ex $(\mathrm{eV})$ & $\log g f$ & Ref. & 1 & 2 & 3 & 4 \\
\hline Fe I & 4001.661 & 2.176 & -1.877 & 1 & $\ldots$ & $\ldots$ & $\ldots$ & $\ldots$ \\
Fe I & 4005.242 & 1.557 & -0.610 & 1 & $\ldots$ & $\ldots$ & 85.60 & $\ldots$ \\
Fe I & 4009.713 & 3.65 & -1.203 & 1 & $\ldots$ & $\ldots$ & 36.50 & 44.60 \\
Fe I & 4014.531 & 3.48 & -0.195 & 1 & 70.00 & 54.70 & 34.80 & $\ldots$ \\
\hline
\end{tabular}

Notes. First four lines only; the full table is only available at the CDS. Equivalent widths are in $\mathrm{mA}$. Stars in Cols. 6 to 17: (1) BS 15621047 (16; 11); (2) BS 16033-081 (86; 18); (3) BS 16077-077 (124; 20); (4) BS 16082-129 (88; 14); (5) BS 16543-097 (100; 20); (6) BS 16929005 (114; 10); (7) CS 22949-008 (52; 6); (8) CS 29503-010 (92; 17); (9) CS 29512-073 (100; 17); (10) CS 29526-110 (27; 6); (11) CS 29528028 (12; 3); (12) CS 31070-073 (37; 9). Numbers in parenthesis after the star name are the number of lines of Fe I and Fe II (Fe I; Fe II). References of the sources of $\log g f$ are shown in Col. 5.

References. (1) NIST; (2) Fuhr \& Wiese (2006).

$$
\begin{aligned}
\sigma_{\log g}= & {\left[\left(\frac{\sigma_{M}}{M \ln (10)}\right)^{2}+\left(\frac{4 \sigma_{T_{\text {eff } *}}}{T_{\text {eff } *} \ln (10)}\right)^{2}+\left(\frac{4 \sigma_{T_{\text {eff }}}}{T_{\text {eff } \odot} \ln (10)}\right)^{2}\right.} \\
& \left.+\sigma_{\log g \odot}^{2}+\left(0.4 \sigma_{V \circ}\right)^{2}+\left(0.4 \sigma_{B C}\right)^{2}+\left(\frac{2 \sigma_{\pi}}{\pi \ln (10)}\right)^{2}\right]^{0.5}
\end{aligned}
$$

where $M_{*}$ is the stellar mass, $V_{\circ}$ is the extinction-corrected magnitude, and $D$ is the distance. For the Sun, we have adopted $T_{\text {eff } \odot}=5781 \mathrm{~K}$ (Bessell et al. 1998); $\log g_{\odot}=4.44 ; M_{\text {bol } \odot}=4.75$ (Cram 1999).

With the first estimates for $T_{\text {eff }}$ and $\log g$, the Fe I and Fe II abundances were calculated using the code WIDTH9 (Castelli 2004), which derives abundances from the equivalent widths (EW) of atomic lines. Table 2 shows the Fe I and Fe II lines, with the respective atomic constants and EW for each star of the DMA subsample. As indicated in Table 2, the main source of oscillator strengths and excitation potential for Fe I lines was the library of the National Institute of Standards and Technology (NIST; Martin et al. 1988, 2002); for Fe II, values by Fuhr \& Wiese (2006) were adopted. A significant number of Fe I lines were used, ranging from 12 to 124 . For two stars, less than $20 \mathrm{Fe}$ I lines were available. Concerning Fe II, most stars had more than 10 lines available. After running WIDTH9, we have the first estimates for the Fe I and Fe II abundances. Iron lines whose abundances were beyond $1 \sigma$ from the overall mean value were discarded for the next iteration.

An isochrone for a given age changes if the metallicity changes, so we have to look for new $M_{V}$ and mass estimates at the isochrone of metallicity closest to that obtained from the WIDTH9 analysis; the process must then be restarted with this new $M_{V}$, so that new photometric temperatures can be derived. In this first iteration, it is not unusual that the abundance of Fe I is very different from that of Fe II. One possible cause for this discrepancy is the inadequacy of the initial choice of $M_{V}$. This means that the value corresponding to the $(B-V)$ with opposite evolutionary state to the first choice is the more suitable $M_{V}$ value to be used. Indeed, if $[\mathrm{Fe} \mathrm{II} / \mathrm{H}]$ is higher than $[\mathrm{Fe} \mathrm{I} / \mathrm{H}]$, $\log g$ must decrease in order to decrease [Fe II/H]. In such a case, the more suitable $M_{V}$ is lower than the first choice. Then, the process must be restarted using the new $M_{V}$ and new parameters derived. When the difference between $\log \epsilon(\mathrm{Fe} \mathrm{I})$ and $\log \epsilon(\mathrm{Fe}$ II) obtained with WIDTH9 is below $0.2 \mathrm{dex}$, and close to those used in the previous iteration, fine tuning adjustments are made. WIDTH9 provides fits for abundance vs. excitation potencial $\left(\chi_{\mathrm{ex}}\right)$ and vs. EW, and analysing their slopes 
for each iteration it is possible to seek the best set of parameters. The temperatures were changed in the atmosphere model depending on whether the $\chi$ slope was positive or negative. When there is no trend between the abundances, $\chi$ ex , and EW we have obtained our desired excitation temperature $\left(T_{\mathrm{ex}}\right)$, and the microturbulent velocity $(\xi)$.

Summarizing, the entire process is iterated until convergence is obtained to a consistent set of parameters. The uncertainties on $T_{\text {ex }}$ and $\xi$ were estimated directly from this iterative process, taking into account the slopes of the best fits. We had many iron lines, hence the random uncertainties on Fe I and Fe II abundances were taken to be the standard error of the mean. The various photometric temperatures derived with the final Fe I and Fe II abundances are shown in Table 3, and all final parameters are listed in Table 4. Photometric temperatures vary considerably - by up to a few hundred $\mathrm{K}$ - for different colour indices, which suggests a need for better photometry and/or transformations. It is worth noting that the Alonso et al. effective temperatures were fairly accurate for $[\mathrm{Fe} / \mathrm{H}] \gtrsim-2.5$ to -2.0 , but become non-physical for metallicities smaller than -3.0 , due to the small number of stars with $[\mathrm{Fe} / \mathrm{H}] \lesssim-2.5$ available in the literature at the time the calibration was undertaken. For this reason, we adopted $T_{\mathrm{ex}}$ as the temperatures for our sample of stars in the DMA analysis.

Other stellar parameters and their uncertainties shown in Table 4 are derived through application of the equations below. Uncertainties on $B C(V)$ are estimated by computing how the uncertainties on $T_{\mathrm{ex}}$ modify their values. From Eqs. (3) to (9), one obtains the absolute magnitude $M_{V}$, the bolometric magnitude $M_{\text {bol }}$, luminosity $\left(L_{*} / L_{\odot}\right)$, and radius $\left(R_{*} / R_{\odot}\right)$, providing as inputs for the distance $D(\mathrm{pc}), A_{V}, V$, and $\log g$ :

$$
\begin{aligned}
& M_{v}=V-5 \log D+5-A_{v} \\
& \sigma_{M_{v}}=\left[\left(\sigma_{V}\right)^{2}+\left(\frac{5 \sigma_{D}}{D \ln (10)}\right)^{2}+\sigma_{A_{v}}^{2}\right]^{0.5} \\
& M_{\mathrm{bol} *}=M_{v}+B C(V) \\
& \sigma_{M_{\mathrm{bol} *}}=\left(\sigma_{M_{v}}^{2}+\sigma_{B C}^{2}\right)^{0.5} \\
& L_{*}=10^{-0.4\left(M_{\mathrm{bol} *}-M_{\mathrm{bol} \odot}\right)} L_{\odot} \\
& \sigma_{L}=L 0.4 \ln (10)\left(\sigma_{M_{\text {bol* }}}^{2}+\sigma_{M_{\text {bole }}}^{2}\right)^{0.5} \\
& R_{*}=\left(\frac{L_{*} T_{\mathrm{eff} \odot}^{4}}{L_{\odot} T_{\mathrm{eff} *}^{4}}\right)^{0.5} R_{\odot} \\
& \sigma_{R}=R\left[\left(\frac{\sigma_{L}}{2 L}\right)^{2}+\left(\frac{2 \sigma_{T_{\text {eff }}}}{T_{\text {eff } \odot}}\right)^{2}+\left(\frac{2 \sigma_{T_{\text {eff } *}}}{T_{\text {eff } *}}\right)^{2}\right]^{0.5} \text {. }
\end{aligned}
$$

\subsection{The SAT subsample}

The SAT analysis is fully described in Tsangarides (2005). For completeness, we present here a short description of his procedure. The grid of model atmospheres was taken from Bell et al. (1976) and Bell (1983, priv. comm.). The former work tabulates model atmospheres for (early-G to early K-type) giants in the parameter space $3750 \mathrm{~K} \leq T_{\text {eff }} \leq 6000 \mathrm{~K}, 0.75 \leq$ $\log g \leq 3.0$ and $-3.0 \leq[\mathrm{Fe} / \mathrm{H}] \leq 0.0$. The latter supplements this parameter space to include dwarfs, main-sequence turnoff stars and subgiants; i.e., it extends the upper limits of effective temperature and surface gravity to $6500 \mathrm{~K}$ and 5.0, respectively. Both works calculate the grid models by scaling the solar
Table 5. Atomic lines for the SAT subsample with atomic constants and EW measurements.

\begin{tabular}{ccccccccc}
\hline \hline Ion & $\lambda(\AA)$ & $\chi_{\text {ex }}(\mathrm{eV})$ & $\log g f$ & Ref. & 1 & 2 & 3 & 4 \\
\hline Ti I & 3729.81 & 0.00 & -0.30 & 7 & $\ldots$ & $\ldots$ & $\ldots$ & $\ldots$ \\
Ti I & 3741.07 & 0.02 & -0.16 & 7 & $\ldots$ & 41.10 & $\ldots$ & $\ldots$ \\
Ti I & 3924.53 & 0.02 & -0.88 & 7 & $\ldots$ & $\ldots$ & $\ldots$ & 74.69 \\
Ti I & 3958.21 & 0.05 & -0.12 & 7 & $\ldots$ & 65.77 & $\ldots$ & 102.90 \\
\hline
\end{tabular}

Notes. First four lines only; the full table is only available on CDS. The first four columns give wavelength, lower-level excitation potential, oscillator strength, and the source of the atomic data, respectively. The remaining 11 columns give the equivalent width in $m \AA ̊$ of each feature measured in these stars. Stars in Cols. 6 to 16: (1) BS 16080175; (2) BS 16090-048; (3) BS 17436-058; (4) BS 17451-031; (5) CS 22171-009; (6) CS 22174-007; (7) CS 22183-015; (8) CS $22887-$ 048; (9) CS 22898-027; (10) CS 29502-092; (11) HD 140283.

References. (1) Fuhr et al. (1988); (2) Kurucz \& Peytremann (1975); (3) NIST; (4) Ryan \& Lambert (1995); (5) Thévenin (1989); (6) Kurucz (1989, priv. comm.); (7) Experimental sources.

abundance ratios of all naturally occurring elements by each model's desired metallicitty.

For the SAT subsample, an earlier version of the code WIDTH9 was used, WIDTH6 (Kurucz \& Furenlid 1979). Table 5 shows the lines, as well as the atomic constants and the EW used as input for the code. As for the DMA subsample, a large number of Fe I were used, ranging from 44 to 105. For Fe II, the number of lines ranges from 7 to 17. SAT used two models for HD 140283. In the first, model A, the temperature, gravity, microturbulence, and iron abundance were all derived from the spectral analysis (requiring ionisation balance). This resulted in a rather low gravity (see Table 6), at odds with the value obtained from HIPPARCos parallax measurements. Consequently, SAT calculated a second model, model B, in which the temperature was determined from IRFM-calibrated colours (using Alonso et al. 1996b), and the gravity was fixed at the parallax value. This created a disparity in the abundances inferred from neutral and ionised Fe lines, suggestive of overionisation. Model B is preferred, but serves as a reminder that for stars without trigonometric parallaxes the results could have greater uncertainties. In order to compare the SAT and DMA procedures, the latter determined atmospheric parameters and abundances of Ti II and C for the star HD 140283. Table 6 shows that both procedures are in good agreement, although the $[\mathrm{C} / \mathrm{Fe}]$ abundance varies considerably between SAT (Model B) and the DMA analysis, despite the similarity between the adopted parameters. The initial model atmosphere for the WIDTH6 calculation was adopted by estimating the metallicity and surface gravity of each target and calculating its effective temperature from the observed colours. SAT estimated the line-of-sight reddening $E(B-V)$ of the targets' observed colours using the dust maps of Schlegel et al. (1998), as shown in Table 1. Then, dereddened colours were used in deriving the initial effective temperatures. These were calculated using the semi-empirical calibrations of Alonso et al. (1996a) for dwarfs and Alonso et al. (1999) for giants. The initial surface gravity of the candidate CEMP stars was estimated based on the approximate evolutionary stage of each target. For stars with colours near the main-sequence turnoff (BS 16080-175, BS 16090-048, BS 17451-031, CS 22171009, CS 22887-048, and CS 22898-027), SAT initially adopted $\log g=4.0$, and for objects with colours on the giant branch (including BS 17436-058, CS 22174-007, CS 22183-015, and 
D. M. Allen et al.: Elemental abundances and classification of CEMP stars

Table 6. Atmospheric parameters and abundances for HD 140283 obtained by SAT and DMA.

\begin{tabular}{lccccc}
\hline \hline & SAT(A) & SAT(B) & DMA & Lit. & Ref. \\
\hline$T_{\text {ex }}(\mathrm{K})$ & $5680 \pm 100$ & $5690 \pm 100$ & $5690 \pm 50$ & 5550 to 5843 & 1 \\
$\log g(\mathrm{cgs})$ & $3.10 \pm 0.10$ & $3.69 \pm 0.10$ & $3.63 \pm 0.12$ & 3.20 to 3.83 & 1 \\
$\xi\left(\mathrm{km} \mathrm{s}^{-1}\right)$ & $1.5 \pm 0.1$ & $1.0 \pm 0.1$ & $1.5 \pm 0.1$ & 0.75 to 1.88 & 1 \\
{$[\mathrm{Fe} \mathrm{I} / \mathrm{H}]$} & $-2.65 \pm 0.20$ & $-2.62 \pm 0.20$ & $-2.66 \pm 0.10$ & -2.70 to -2.21 & 1 \\
{$[\mathrm{Fe} \mathrm{II} / \mathrm{H}]$} & $-2.65 \pm 0.20$ & $-2.39 \pm 0.20$ & $-2.44 \pm 0.10$ & & \\
{$[\mathrm{C} / \mathrm{Fe}]$} & $0.59 \pm 0.27$ & $0.13 \pm 0.10$ & $0.71 \pm 0.10$ & 0.22 to 0.60 & $2,3,4,5$ \\
{$[\mathrm{Ti} \mathrm{II} / \mathrm{Fe}]$} & $0.11 \pm 0.02$ & $0.13 \pm 0.10$ & $0.23 \pm 0.10$ & 0.23 to 0.27 & 3,4 \\
\hline
\end{tabular}

Notes. Model (A) results are shown in Col. 2, model (B) results are shown in Col. 3, and the DMA results are shown in Col. 4. Column 5 shows the range of results from the references in Col. 6. The atmospheric parameters and abundances of model SAT(A) were calculated concurrently, while the IRFM effective temperature (Alonso et al. 1996b) and parallax surface gravity were used in model SAT(B).

References. (1) Tsangarides (2005); (2) Tomkin et al. (1992); (3) Norris et al. (1997); (4) Aoki et al. (2002e); (5) Akerman et al. (2004).

CS 29502-092), $\log g=2.5$. An incorrect initial gravity implied longer computation times for the abundances of Fe I and Fe II to converge, but since the final adopted $\log g$ was set using the Fe ionisation balance, it was not affected by the starting value. The metallicity of the model has the smallest effect on the derived abundances among these three atmospheric parameters, which was illustrated by a posterior error analysis. Therefore, $[\mathrm{Fe} / \mathrm{H}]=-1.5$ for all the initial models were adopted, which is the mean Population II metallicity (Laird et al. 1988). All photometric temperatures and final parameters adopted for the SAT subsample are shown in Tables 3 and 4.

\section{Abundances and uncertainties}

\subsection{Effectiveness of the selection method}

The stellar parameters and $[\mathrm{Fe} / \mathrm{H}]$ values derived in Sect. 2 enable us to examine the effectiveness of the selection criteria used for the CEMP stars. The majority of these CEMP candidates are confirmed as metal-poor stars. The five exceptions are as follows. BS 17451-031 has two disparate $B-V$ colours, provided in Table 1 . The excitation temperature $(5800 \mathrm{~K})$ is consistent with the more recent, bluer colour. We infer that because of the older and presumably erroneous colour, viz. $B-V=0.711$, this Sun-like dwarf was originally mistaken as a cool giant and, being weak lined compared to genuine giants, was misclassified as metal-poor but, as with other Sun-like dwarfs, having a prominent G-band. BS 16086-022 and CS 22169-002 were found to have extremely broad $\mathrm{H}_{\gamma}, \mathrm{H}_{\epsilon}$ and $\lambda 4324$ features, which reveal them to be white dwarfs. The only narrow lines in these spectral regions are the $\mathrm{Ca}$ II $\mathrm{H}$ and $\mathrm{K}$ lines, which are likely of interstellar origin. For this reason, these two white dwarfs were misclassified as metal-poor candidates in the HK-survey objective-prism selection. The spectra also exhibit a broad, shallow depression of flux around $4310 \AA$. The broad $4310 \AA$ and $4324 \AA$ depressions coincide with the CH G-band, and suggest these stars to be C-rich (DQ) white dwarfs. BS 16542-052 was listed amongst the emission line candidates of Beers et al. (1994). Our spectrum showed it to be strong lined, with a preliminary analysis indicating $[\mathrm{Fe} / \mathrm{H}] \sim-0.8$. This star is unlikely to be a CEMP star, and is more likely a mildly metal-poor star with a normal G-band. The $\mathrm{Ca}$ II $\mathrm{H}$ and $\mathrm{K}$ lines did not appear in emission at the time of our observation. We chose not to analyse it further. Our spectrum of BS 16088-104 showed this star to be quite strong lined, with a preliminary analysis (conducted by A. Hosford) indicating $[\mathrm{Fe} / \mathrm{H}] \sim-0.3$. As it was almost certainly misclassified as a CEMP star; we did not analyse it further.

We have found five misclassified stars in our echelle observations of 26 CEMP candidates, corresponding to a false-positive rate of $19 \%$ in the original sample selection. We do not consider these stars further.

\subsection{Other elemental abundances}

For the elements other than Fe, abundances were derived through 1D LTE spectrum synthesis, using the code SYNTHE created by R. Kurucz, or in the case of the SAT analysis, the synthesis code ATLAS by Cottrell \& Norris (1978). Abundances of carbon were derived using molecular synthesis of the G-band $\left(\mathrm{CH} \mathrm{A}^{3} \Delta-\mathrm{X}^{3} \pi\right)$ at $\lambda \lambda 4290-4315 \AA$. Atomic lines were used to calculate the abundances of $\mathrm{Na}, \mathrm{Mg}, \mathrm{Sc}, \mathrm{Ti}, \mathrm{Cr}, \mathrm{Cu}, \mathrm{Zn}, \mathrm{Sr}, \mathrm{Y}$, $\mathrm{Zr}, \mathrm{Ba}, \mathrm{La}, \mathrm{Ce}, \mathrm{Nd}, \mathrm{Sm}, \mathrm{Eu}, \mathrm{Gd}$, Dy by DMA, and Ti, Zn, Sr, Y, $\mathrm{Zr}, \mathrm{Ba}, \mathrm{La}, \mathrm{Eu}, \mathrm{Pb}$ by SAT. Table 5 shows the lines used for the SAT subsample; Table 7 lists the abundances line by line, along with the respective atomic constants for the DMA subsample.

The oscillator strengths for elements other than Fe, and their respective sources, are shown in Table 7. For the $\alpha$ - and ironpeak elements, most values are from NIST; a few data are from VALD (Piskunov et al. 1995; Ryabchikova et al. 1997; Kupka et al. 1999, 2000). Laboratory values, where available, were given preference over theoretical values. For the lines of $\mathrm{Cu}$, Eu II, La II, and Ba II the hyperfine structure $(h f s)$ was taken into account, employing a code made available by A. McWilliam, following the calculations described by Prochaska et al. (2000). The $h f s$ constants were taken from Rutten (1978) for Ba II, Lawler et al. (2001a) for La II, and Lawler et al. (2001b) for Eu II. The final $h f s$ components were determined by using the solar isotopic mix by Lodders (2003) and the total $\log g f$ values from laboratory measurements. For copper, the $h f s$ from Biehl (1976) was used, with isotopic fractions of 0.69 for ${ }^{63} \mathrm{Cu}$ and 0.31 for ${ }^{65} \mathrm{Cu}$. In this case, small corrections were applied such that the total $\log g f$ equals the $g f$ value adopted in this work. The lines for which $h f s$ were used were tested by creating a sinthetic solar spectrum to compare to the solar observed spectrum by Kurucz et al. (1984).

Tables 8 and 9 show the average abundance for the elements in each star, for the DMA and remaining SAT subsamples, respectively. For most elements, the solar abundances used were extracted from Grevesse \& Sauval (1998); full references are indicated in Table 8 . The usual notations 
Table 7. Lines, equivalent widths, and abundances for the DMA subsample.

\begin{tabular}{lcccccccc}
\hline \hline Star & el & $\lambda$ & $\chi_{\text {ex }}$ & $\log g f$ & Ref. & EW & $\log \epsilon$ & {$[\mathrm{X} / \mathrm{Fe}]$} \\
\hline BS 15621-047 & $\mathrm{C}$ & G-band & $\ldots$ & $\ldots$ & $\ldots$ & $\ldots$ & 7.23 & 1.06 \\
BS 15621-047 & $\mathrm{Na}$ I 4982.808 & 2.100 & -1.913 & 1 & 26 & 5.33 & 1.35 \\
BS 15621-047 & $\mathrm{Na}$ I & 4982.813 & 2.100 & -0.961 & 1 & $\ldots$ & $\ldots$ & $\ldots$ \\
BS 15621-047 & $\mathrm{Na}$ & 5682.650 & 2.100 & -0.700 & 1 & $\ldots$ & $\ldots$ & $\ldots$ \\
BS 15621-047 & $\mathrm{Na}$ I & 5688.193 & 2.104 & -1.390 & 1 & 60 & 5.33 & 1.35 \\
\hline
\end{tabular}

Notes. See below for the $\log g f$ sources indicated in Col. 6. The full table is only available at CDS.

References. 1. NIST; 2. Fuhrmann et al. (1995); 3. Martin et al. (1988); 4. Bielski (1975); 5. Biémont \& Godefroid (1980); 6. Gratton \& Sneden (1994); 7. Hannaford et al. (1982); 8. Hannaford \& Lowe (1983); 9. Biémont et al. (1981); 10. Thévenin (1989); 11. Sneden et al. (1996); 12. McWilliam (1998); 13. Lawler et al. (2001a); 14. Palmeri et al. (2000); 15. Hartog et al. (2003); 16. Maier \& Whaling (1977); 17. Biémont et al. (1989); 18. Lawler et al. (2001b); 19. Corliss \& Bozman (1962); 20. VALD; 21. Bergstrom et al. (1988); 22. average of Kusz (1992) and Biémont \& Lowe (1993).

$\log \epsilon(\mathrm{A})=\log \left(N_{\mathrm{A}} / N_{\mathrm{H}}\right)+12$ and $[\mathrm{A} / \mathrm{B}]=\log \left(N_{\mathrm{A}} / N_{\mathrm{B}}\right)_{*}-$ $\log \left(N_{\mathrm{A}} / N_{\mathrm{B}}\right)_{\odot}$ were adopted.

Uncertainties in the abundances were evaluated by consideration of the degree to which a variation of $1 \sigma$ in the atmospheric parameters and $\mathrm{S} / \mathrm{N}$ affected the output value of the synthesis routine. For details of the error calculations, see Appendix A.

Although the errors in the atmospheric parameters are usually the dominant source of the total error on the abundance estimates, observational sources can be more significant at a $\mathrm{S} / \mathrm{N}$ around 40 . A change of $50 \mathrm{~K}$ in $T_{\text {eff }}$ leads to a change of typically 0.03 dex in $[\mathrm{X} / \mathrm{Fe}]$, with the largest change being $0.10 \mathrm{dex}$ for some elements. Changes of $0.10 \mathrm{dex}$ in $\log g$ result in alterations of $[\mathrm{X} / \mathrm{Fe}]$ of up to 0.04 dex. Changes of $0.10 \mathrm{~km} \mathrm{~s}^{-1}$ in $\xi$ lead to $[\mathrm{X} / \mathrm{Fe}]$ changes up to $0.03 \mathrm{dex}$. For the present sample, the major contribution to the uncertainties on $[\mathrm{X} / \mathrm{Fe}]$ is the $\mathrm{S} / \mathrm{N}$ achieved in the spectra. For example, for BS 16077077 (the star in our sample with the highest $\mathrm{S} / \mathrm{N}$ ) the contribution of error due to $\mathrm{S} / \mathrm{N}$ ranges typically from 0.07 dex to $0.15 \mathrm{dex}$, reaching, for some elements with very weak lines, as high as 0.40 dex. For stars with $\mathrm{S} / \mathrm{N}$ around 30 , the contribution to the uncertainties is even higher, ranging typically from 0.10 dex to 0.30 dex, reaching 0.50 dex for some elements. Uncertainties are listed in Table 8.

\section{Discussion}

In order to study the distributions of elemental abundances for as many known CEMP stars as possible, an extensive search for abundances available in the literature has been performed. Elemental abundances for $\mathrm{C}, \mathrm{N}, \mathrm{O}, \mathrm{Na}, \mathrm{Mg}, \mathrm{Al}, \mathrm{Si}, \mathrm{Ca}, \mathrm{Sc}, \mathrm{Ti}$, V, Cr, Mn, Co, Ni, Zn, Sr, Y, Zr, Ba, La, Ce, Pr, Nd, Sm, Eu, $\mathrm{Dy}$, and $\mathrm{Pb}$ (see Tables B.1 to B.4) are shown in the figures, together with abundances for our sample stars. The following criteria were applied to the literature data:

- only data with resolving power $R>30000$ were used;

- if two works belong essentially to the same group of scientists, the more recent value was adopted;

- the average abundance was taken for the same star studied by different groups;

- an upper limit was used only when there was no other value available.
One difficulty in combining data from the literature is that we no longer have a homogeneous abundance analysis, since different authors employ different procedures which could involve different line lists, atomic data for the lines used, adopted solar abundances, model atmospheres, and spectrum synthesis codes. All of these could contribute to an increase in the scatter in the patterns of observed abundances.

Eight stars from our observational program are in common with other works from the literature meeting the criteria above, as shown in Table 10. However, among those, only four had an Eu abundance determined elsewhere. For the others, Eu abundances were determined here for the first time. We have chosen not to average our measurements with others from the literature.

\subsection{C-rich stars: selection and classification}

Carbon abundances for the 21 stars for which we have analysed $\mathrm{C}$ (Tables 8 and 9 ) are in the range $+0.25 \leq[\mathrm{C} / \mathrm{Fe}] \leq+2.76$. Of these, only three (BS 16033-081, BS 16090-048, and CS 22174-007) have $[\mathrm{C} / \mathrm{Fe}]<+1.0$, falling below the formal threshold for classification as a CEMP star (the usual definition for CEMP objects is $[\mathrm{C} / \mathrm{Fe}]>+1.0$; Beers \& Christlieb 2005), although even two of these have $[\mathrm{C} / \mathrm{Fe}]>+0.6$, i.e. four times the solar ratio. In addition, the star CS 22171-009 has an upper limit of $[\mathrm{C} / \mathrm{Fe}]<+1.03$, so it may not be $\mathrm{C}$-rich.

At face value, this suggests a further $14 \%$ misclassification (false positives) in the CEMP-star selection, or overall a $\sim 70 \%$ success rate in identifying genuine CEMP objects. However, according to Aoki et al. (2007), some stars with $[\mathrm{C} / \mathrm{Fe}]<+1.0$ could still be CEMP stars, depending on their evolutionary stage, since the surface carbon abundance is expected to decrease after first dredge-up. Following their criteria, CS 30322-023 was classified by them as CEMP star, although it has $[\mathrm{C} / \mathrm{Fe}]=+0.56$. This is one of the stars from the literature represented by open triangles in Fig. 1. Other stars from the literature with low $[\mathrm{C} / \mathrm{Fe}]$ that could still be considered CEMP stars are shown in Fig. 1: CS 22885-096 with $[\mathrm{C} / \mathrm{Fe}]=+0.60$ (cross, Norris et al. 2001), CS 30314-067 with $[\mathrm{C} / \mathrm{Fe}]=+0.50$ (cross, Aoki et al. 2002a), BS 17435-532 with $[\mathrm{C} / \mathrm{Fe}]=+0.68$ (filled square, Roederer et al. 2008). Applying the Aoki et al. criteria for stars of this work, BS 16033-081 with $[\mathrm{C} / \mathrm{Fe}]=+0.77$ also can be considered C-rich. Consequently, 18 among 21 stars of our sample are C-rich.

Large over-abundances of $\mathrm{C}$ and $\mathrm{N}$ in CEMP stars are usually explained by one of three mechanisms: mass transfer from a companion AGB star in a binary system (environmental); selfenrichment of the star in these elements (internal); or from the star having been born from a reviously-enriched cloud (congenital). Mechanisms to produce such large amounts of $\mathrm{C}$ and $\mathrm{N}$ in population III stars have been studied by, e.g., Fujimoto et al. (2000) and Siess et al. (2002), who claim that if mixing is efficient during the He-flash in the core when the star reaches the tip of the red-giant branch, $\mathrm{C}$ and $\mathrm{N}$ abundances can be significantly enhanced. However, that mechanism cannot be the origin of internal $\mathrm{C}$ and $\mathrm{N}$ enrichment in stars that have not reached this evolutionary stage, as can be seen from $\log g$ in Table B.1. For example, if the evolutionary stage of the very Cand N-rich star HE 1327-2326 is a dwarf or subgiant (present evidence suggests a subgiant classification; Korn et al. 2009), this mechanism cannot be applied, and the source of these elements must be extrinsic (environmental or congenital). Very massive stars (e.g., Wolf-Rayet stars) undergo significant mass loss during the red supergiant stage, releasing $\mathrm{C}$ and $\mathrm{N}$ to the interstellar medium. Hirschi (2007) claim that the CNO abundances of 
Table 11. Stars with anomalously high abundances of $\mathrm{O}, \mathrm{Na}, \mathrm{Mg}$, $\mathrm{Al}$, or $\mathrm{Si}$ compared with $\mathrm{Ca}$. For elements other than $\mathrm{Ca}$, there are many values around or above $[\mathrm{X} / \mathrm{Fe}]=+1.4$.

\begin{tabular}{lccccccc|ccc}
\hline \hline Star & {$[\mathrm{Fe} / \mathrm{H}]$} & {$[\mathrm{C} / \mathrm{Fe}]$} & {$[\mathrm{O} / \mathrm{Fe}]$} & {$[\mathrm{Na} / \mathrm{Fe}]$} & {$[\mathrm{Mg} / \mathrm{Fe}]$} & {$[\mathrm{Al} / \mathrm{Fe}]$} & {$[\mathrm{Si} / \mathrm{Fe}]$} & {$[\mathrm{Ca} / \mathrm{Fe}]$} & $\mathrm{Cls}$. & $\mathrm{Refs}$. \\
\hline HE 1012-1540 & -3.43 & 2.22 & 2.25 & 1.21 & 1.88 & 0.93 & 1.07 & 0.57 & $\mathrm{no}$ & 40 \\
HE 1327-2326 & -5.96 & 3.78 & 3.42 & 2.73 & 1.97 & 1.46 & $\ldots$ & 0.44 & li & 35,39 \\
CS 29498-043 & -3.54 & 2.09 & 2.43 & 1.47 & 1.75 & 0.27 & 0.82 & 0.16 & no & $25,11,12$ \\
CS 22949-037 & -3.84 & 1.06 & 1.97 & 1.77 & 1.42 & -0.04 & 0.77 & 0.37 & no & $6,14,15,40$ \\
CS 29528-028 & -2.86 & 2.77 & $\ldots$ & 2.68 & 1.69 & $\ldots$ & $\ldots$ & 0.46 & $\mathrm{~b}+$ & 37 \\
HE 1447+0102 & -2.47 & 2.48 & $\ldots$ & 1.07 & 1.43 & $\ldots$ & $\ldots$ & 0.88 & $\mathrm{~b}+$ & 37 \\
SDSS 1707+58 & -2.49 & 2.1 & $\ldots$ & 2.71 & 1.13 & $\ldots$ & $\ldots$ & 0.79 & $\mathrm{~b}+$ & 41 \\
CS 29497-034 & -2.90 & 2.68 & $\ldots$ & 1.48 & 1.02 & -0.01 & $\ldots$ & 0.48 & $\mathrm{rs}$ & $5,29,37$ \\
CS 22942-019 & -2.60 & 2.1 & 0.97 & 1.44 & 0.65 & -0.35 & $\ldots$ & 0.68 & $\mathrm{~s}$ & $8,12,46$ \\
CS 22958-042 & -2.85 & 3.15 & 1.35 & 2.85 & 0.32 & -0.85 & 0.15 & 0.36 & no & 33 \\
CS 29528-041 & -3.30 & 1.59 & 1.40 & 1.20 & 0.40 & -0.85 & -0.20 & 0.40 & $\mathrm{~b}+$ & 33 \\
CS 29497-030 & -2.67 & 2.58 & 1.58 & 0.55 & 0.49 & -0.67 & -0.01 & 0.50 & $\mathrm{~s}$ & 21,27 \\
CS 31080-095 & -2.85 & 2.69 & 2.35 & -0.28 & 0.65 & -0.95 & 0.05 & 0.17 & $\mathrm{~b}-$ & 33 \\
HE 0557-4840 & -4.75 & 1.65 & $<3.09$ & -0.16 & 0.25 & -0.61 & $\ldots$ & 0.25 & li & 38 \\
\hline CS 30314-067 & -2.85 & 0.5 & $\ldots$ & -0.08 & 0.42 & -0.10 & 0.80 & 0.22 & $\mathrm{no}$ & 10 \\
CS 29502-092 & -2.76 & 1.0 & $\ldots$ & -0.01 & 0.37 & -0.77 & 0.84 & 0.27 & no & 10 \\
\hline
\end{tabular}

Notes. The tenth column shows the classification of the CEMP stars according to Beers \& Christlieb (2005): s = CEMP-s, rs $=$ CEMP-rs, no $=$ CEMP-no, $\mathrm{b}+=$ stars with $[\mathrm{Ba} / \mathrm{Fe}]>1$ with no Eu abundance, $\mathrm{b}-=$ stars with $0<[\mathrm{Ba} / \mathrm{Fe}]<1$ with no Eu abundance, li $=$ stars with only an upper limit for both the Eu and $\mathrm{Ba}$ abundances. The last column shows the abundance references, as enumerated below. For stars with more than one reference, the adopted value is the average or one of the references, according to criteria explained in the text.

References. (5) Hill et al. (2000); (6) Norris et al. (2001); (8) Preston \& Sneden (2001); (10) Aoki et al. (2002a); (11) Aoki et al. (2002b); (12) Aoki et al. (2002c); (14) Depagne et al. (2002); (15) Norris et al. (2002); (21) Sivarani et al. (2004); (25) Aoki et al. (2004); (27) Ivans et al. (2005); (29) Barbuy et al. (2005); (33) Sivarani et al. (2006); (35) Aoki et al. (2006b); (37) Aoki et al. (2007); (38) Norris et al. (2007); (39) Frebel et al. (2008); (40) Cohen et al. (2008); (41) Aoki et al. (2008); (46) Masseron et al. (2010).

HE 1327-2326 can be reproduced by the winds of their rotating massive-star models. Umeda \& Nomoto (2003) have simulated the supernova explosion of population III progenitors from 20 to $130 M_{\odot}$ and calculated the expected nucleosynthesis yields. In their $25 M_{\odot}$ model, $\mathrm{CNO}$ are produced during the pre-supernovae phase, in He shell burning, and although $\mathrm{N}$ is underproduced in this stage, it could have already been produced through the $\mathrm{C}-\mathrm{N}$ cycle, and brought up to the surface during the first dredge-up stage. In this model, only a small amount of the heavier elements such as $\mathrm{Mg}, \mathrm{Ca}$, and the iron-peak elements are produced. Umeda \& Nomoto claim that the elemental abundances for this model are in good agreement with the abundances of HE 0107-5240 by Christlieb et al. (2002, 2004), characterized by very large $[\mathrm{C} / \mathrm{Fe}]$ and $[\mathrm{N} / \mathrm{Fe}]$ ratios, while the abundances of elements heavier than $\mathrm{Mg}$ are normal.

Because of the relation between the r-process and massive star evolution (Truran 1981; Woosley \& Weaver 1995), the expectation is that there might be evidence of element production from the r-process in the early Galaxy. In contrast, due to the secondary nature of the s-process, the naive expectation is that evidence of this source in metal-deficient stars should be scarce (Truran 1981; Travaglio et al. 1999). However, many CEMP stars have been found to exhibit clear s-process signatures (Norris et al. 1997). Given that $\mathrm{Ba}$ and $\mathrm{Eu}$ are significant representatives of the s- and r-processes in Solar System material, CEMP-star classifications emerged to reflect their neutroncapture element compositions. Beers \& Christlieb (2005) defined subclasses of CEMP stars as follows:

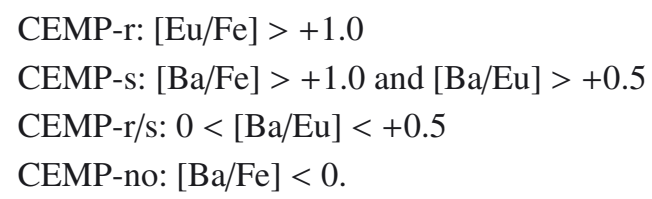

Aoki et al. (2002b) obtained large over-abundances of C, N, Mg and Si from their analysis of CS 29498-043, and suggested a new class of CEMP stars - CEMP- $\alpha$.

The $[\mathrm{Ba} / \mathrm{Eu}]$ ratio for the stars from the literature was determined (see Table B.1). Then, following the Beers \& Christlieb definition, we found that 19 stars in the literature sample are CEMP-s, 2 are CEMP-r, 15 are CEMP-r/s, and 15 might be CEMP-no, although among the latter only one has had its Eu abundance determined, 7 have only an upper limit, and 7 have no Eu abundance estimated; such stars are represented by different symbols in Figs. 1-6, and their stellar classifications are indicated in Table B.1. Five stars among the 109 stars cannot be classified yet, since they have no published $\mathrm{Ba}$ or Eu abundance.

\subsection{The $\alpha$ - and iron-peak elements}

Figure 1 shows that the runs of $[\mathrm{X} / \mathrm{Fe}]$ vs. $[\mathrm{Fe} / \mathrm{H}]$ for most of the CEMP stars follow the canonical trend of metal-poor stars for $\mathrm{O}$, $\mathrm{Na}, \mathrm{Mg}, \mathrm{Al}, \mathrm{Si}$, and $\mathrm{Ca}$ (Tsangarides 2005 did not compute abundances for $\mathrm{Na}$, nor for $\mathrm{V}, \mathrm{Mn}, \mathrm{Co}$, or $\mathrm{Ni}$ ). The $\mathrm{Mg}$ abundance for the CEMP stars in Fig. 1 remains around $[\mathrm{Mg} / \mathrm{Fe}]=+0.5$, according to the canonical $\alpha$-element behaviour, except for six stars with $[\mathrm{Fe} / \mathrm{H}]<-2.40$, for which very high $\mathrm{Mg}$ abundances are found, $[\mathrm{Mg} / \mathrm{Fe}]>+1.4$ (see Table 11): CS 22949-037, CS 29498-043, CS 29528-028, HE 1447+0102, HE 1327-2326, and HE 1012-1540. These six stars are outlined in Fig. 1 by large open squares, where they are seen to also have $[\mathrm{Na} / \mathrm{Fe}] \gtrsim+1.2$. In addition, most of the Mg-rich stars also have high [Al/Fe] ratios (Fig. 1), so the CEMP- $\alpha$ class would appear to be enriched in a wider set of elements including $\mathrm{Na}, \mathrm{Mg}$ and $\mathrm{Al}$, implying that a "CEMP-light" classification might be more appropriate than CEMP- $\alpha$. In fact, both of these suggested sub-classes are also CEMP-no stars, so the nomenclature should be revisted. 
The stars CS 22942-019, CS 29497-034, SDSS 1707+58, CS 22958-042, shown in Table 11 , also have $[\mathrm{Na} / \mathrm{Fe}] \geq+1.4$, although their $[\mathrm{Mg} / \mathrm{Fe}]$ ranges from +0.3 to +1.1 . The star with a high $\mathrm{Na}$ abundance represented by a filled triangle in Fig. 1 without a big open square surrounding it is SDSS 1707+58, for which Aoki et al. (2008) determined $[\mathrm{Na} / \mathrm{Fe}]=+2.71$ and $[\mathrm{Mg} / \mathrm{Fe}]=+1.13$. One star of the present sample, BS 15621047 , also has a high $\mathrm{Na}$ abundance, with $[\mathrm{Na} / \mathrm{Fe}]=+1.35$ and $[\mathrm{Mg} / \mathrm{Fe}]=+0.85$ (see Table 8 ).

As seen in Table 11, some CEMP stars exhibit large overabundances of the lighter elements $\mathrm{N}, \mathrm{O}, \mathrm{Na}, \mathrm{Mg}$, and $\mathrm{Si}$, in particular among the lowest metallicity stars (Aoki et al. 2007). This table suggests that all CEMP stars with high $[\mathrm{Mg} / \mathrm{Fe}]$ and $[\mathrm{Na} / \mathrm{Fe}]$ are also oxygen-rich, with $[\mathrm{O} / \mathrm{Fe}] \gtrsim+1.0$. Unfortunately, some of these stars have no oxygen abundance available in the literature to confirm this point. It is worth noting that other stars in Table 11, CS 29497-030, CS 29528-041, CS 31080-095, and HE 0557-4840 are O-rich, but are not Na- or Mg-rich. Three of the stars in Table 11 with high $\mathrm{Mg}$ abundances have also the highest $\mathrm{Si}$ abundances, with $[\mathrm{Si} / \mathrm{Fe}]$ ranging from +0.8 to +1.1 . However, the last two stars, CS 30314-067 and CS 29502-092, have $[\mathrm{Si} / \mathrm{Fe}]$ in this range, but their $\mathrm{Mg}, \mathrm{Na}$ and $\mathrm{O}$ abundances are low. In contrast to $\mathrm{O}$ and $\mathrm{Na}, \mathrm{C}$ and $\mathrm{N}$ seem to have no correlation with the high over-abundance of $\mathrm{Mg}$. Figure $5 \mathrm{c}$ makes the pattern of $[\mathrm{Mg} / \mathrm{Fe}]$ vs. $[\mathrm{C} / \mathrm{Fe}]$ clearer, where one can see that stars with the highest $\mathrm{Mg}$ abundance are spread over the range $+1.0 \lesssim[\mathrm{C} / \mathrm{Fe}] \lesssim+3.8$.

The $[\mathrm{Ca} / \mathrm{Fe}]$ ratios for all of these stars are not as high as $[\mathrm{O} / \mathrm{Fe}],[\mathrm{Na} / \mathrm{Fe}]$, and $[\mathrm{Mg} / \mathrm{Fe}]$, and the $\mathrm{Ca}$ abundance has no relationship with a high $\mathrm{Mg}$ abundance. Figure 1 shows that $[\mathrm{Ca} / \mathrm{Fe}]$ vs. $[\mathrm{Fe} / \mathrm{H}]$ follows a flat pattern, and Fig. 2 shows that the same occurs for the abundances of elements lighter than $\mathrm{Zn}$ for different classes of CEMP stars, with only a few exceptions. HE 1327-2326 has only upper limits for V, Zn, Mn, and Co. For other elements, the CEMP star abundances follow the general trend formed by other stars. Table 11 also indicates that there is no segregation among stars with high over-abundance of the $\alpha$-elements according to the class of CEMP star, since one can find several classes of CEMP stars with this characteristic.

Large over-abundances relative to iron for these intermediate-mass elements cannot be explained by (environmental) mass transfer from a companion AGB star. Turatto et al. (1998) and Zampieri et al. (2003) used the fallback supposition to explain the observed low Fe abundance for SN 1997D and SN 1999br, respectively, and claim that similar SNe may be the origin of the abundance pattern of stars with high abundances of $\mathrm{Na}, \mathrm{Mg}$, or $\mathrm{Si}$ relative to iron-peak elements. These supernovae, characterized by relatively small Fe ejection, are massive, but less energetic, and very underluminous (Woosley \& Weaver 1995), the so-called "faint supernovae". In this view, extremely metal-poor stars without enhancements of $\mathrm{C}$ and $\mathrm{N}$ correspond to the abundance patterns from energetic supernovae (Umeda \& Nomoto 2003). CEMP stars with large over-abundances of intermediate-mass elements may have similarly formed, in a congenital scenario, from gas enriched by $\mathrm{SN}$ experiencing partial fallback of heavier material onto the collapsed remnant. In this case, $\mathrm{Ca}, \mathrm{Fe}$, as well as other $\mathrm{Fe}$-group elements such as $\mathrm{Cr}, \mathrm{Mn}, \mathrm{Co}$, and Ni produced in the deep interior, would fall back onto the nascent neutron star. In contrast, lighter elements synthesized in the outer layers of the star would be ejected and be excluded from any fallback. As a result, lighter elements are significantly enhanced with respect to Fe-group elements. Aoki et al. (2004) and Cohen et al. (2008) claim that the observed elemental abundance patterns of CS 29498-043 and CS 22949-037, respectively, exhibit characteristics that fit this explanation. The high redshift $(z=2.3)$, extremely metal-poor Damped Lyman- $\alpha$ (DLA) system recently reported by Cooke et al. $(2011,[\mathrm{Fe} / \mathrm{H}] \sim-3.0)$ exhibits an enhanced carbon-to-iron ratio $([\mathrm{C} / \mathrm{Fe}]=+1.5)$ and other elemental abundance signatures that Kobayashi et al. (2011) associate with production by faint supernovae which experienced mixing and fallback.

Another possible progenitor for this class is massive, rapidly rotating, mega metal-poor $([\mathrm{Fe} / \mathrm{H}]<-6.0)$ stars, which models suggest have greatly enhanced abundances of CNO due to distinctive internal burning and mixing episodes, followed by strong mass loss (Hirschi et al. 2006; Meynet et al. 2006, 2010a,b). It is also of interest that Matsuoka et al. (2011) have reported evidence for strong carbon production in the early universe, based on their analysis of the optical spectrum of the most distant known radio galaxy, TN J0924-2201, with $z=5.19$. There is the exciting possibility that the same or similar progenitors, likely associated with the very first generations of stars, are responsible for the distinctive abundance patterns in both the CEMP-no stars and the high-redshift gas and galaxies.

\subsection{Neutron-capture elements}

\subsubsection{Abundances}

The behaviour of the neutron-capture-element abundances shown in Figs. 3 and 4 is remarkably different from the behaviour seen in Figs. 1 and 2 for the lighter elements. While in Figs. 1 and 2 all symbols are mixed together, the scatter is much higher in Figs. 3 and 4. However, if one considers only data with the same symbol (excluding data of this work), the scatter is lower than when considering all data. Given that the different symbols are defined according to $\mathrm{Ba}$ and $\mathrm{Eu}$ abundances, this separation is most likely a consequence of the contribution of the $r$ - and s-processes, which increase the abundances of neutroncapture elements in different degrees for each class of star. It is worth recalling that the difference among the procedures adopted by different authors might increase the scatter observed in the reported abundance patterns.

The pattern of abundances of the neutron-capture elements for the stars with large over-abundances of $\mathrm{Mg}$ (large open squares involving other symbols) is not as clear as for the lighter elements. The stars CS 22949-037, CS 29498-043, and $\mathrm{HE} 1012-1540$ have $[\mathrm{Ba} / \mathrm{Fe}]<0$, whereas CS 29528-028, HE 1447+0102 and HE 1327-2326 have very high barium abundances, with $[\mathrm{Ba} / \mathrm{Fe}]=+3.27\left(+2.49\right.$ in this work $\left.^{6}\right),+2.70$, and +1.40 , respectively. Three of these stars, CS 22949-037, HE 1012-1540, and HE 1327-2326 have only upper limits for $[\mathrm{Eu} / \mathrm{Fe}]$ published $(<+0.57,<+1.62,<+4.64$, respectively), and the three remaining have no published $\mathrm{Eu}$ abundance. The lack of accurate abundances for $[\mathrm{Eu} / \mathrm{Fe}]$ prevents a more meaningful analysis of the possible relationship between the $\alpha$-elements and the r-process elements.

Figure 5 exhibits an increasing trend for $[\mathrm{Ba} / \mathrm{Fe}]$ vs. $[\mathrm{C} / \mathrm{Fe}]$. While not all $\mathrm{C}$-enhanced stars are $\mathrm{Ba}$ enhanced, those that are lie on or below the envelope at $[\mathrm{Ba} / \mathrm{C}]=0$; a fiducial line with $[\mathrm{Ba} / \mathrm{C}]=0$ is drawn to guide the eye. This behaviour of $\mathrm{Ba}-$ a spread in $[\mathrm{Ba} / \mathrm{C}]$ with an upper bound at constant $[\mathrm{Ba} / \mathrm{C}]$ (where $\mathrm{C}$ is presumably ${ }^{12} \mathrm{C}$ ) - might be understood as the

\footnotetext{
6 The origin of the large difference between the $\mathrm{Ba}$ abundance of this star obtained in this work and Aoki et al. (2007) might be the significant difference in atmospheric parameters (see Table 10) adopted by these works.
} 

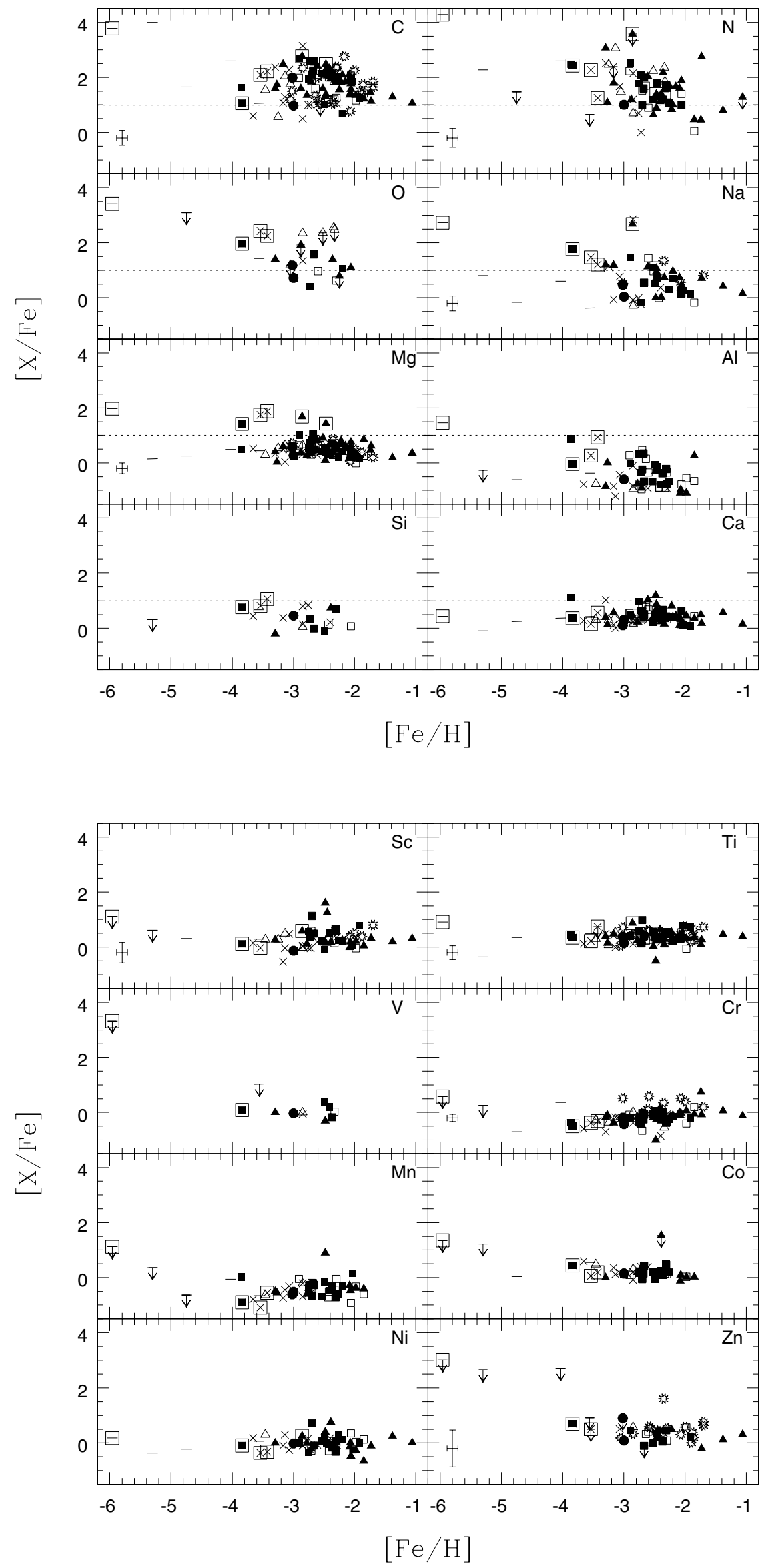

Fig. 1. $[\mathrm{X} / \mathrm{Fe}]$ for CEMP stars of this work and from the literature. Symbols - starred circles: this work; filled squares: $0<[\mathrm{Ba} / \mathrm{Eu}] \lesssim$ 0.5 (CEMP-r/s); open squares: $[\mathrm{Ba} / \mathrm{Eu}]>$ 0.5 (CEMP-s); crosses: $[\mathrm{Ba} / \mathrm{Fe}]<0$ (CEMPno); filled triangles: $[\mathrm{Ba} / \mathrm{Fe}]>+1$ but there is no available Eu abundance ( $\mathrm{s}$ or $\mathrm{r} / \mathrm{s}$ ?); open triangles: $0<[\mathrm{Ba} / \mathrm{Fe}]<+1$ but there is no available $\mathrm{Eu}$ abundance (r?); filled circles: $[\mathrm{Ba} / \mathrm{Eu}]<0(\mathrm{r})$; dashes: upper limit for $\mathrm{Ba}$ and $\mathrm{Eu}$; big open squares involving four crosses, two filled triangles and one dash indicate high over-abundance of $\mathrm{Mg}$, $[\mathrm{Mg} / \mathrm{Fe}]>+1.4$. The dotted lines indicate where $[\mathrm{X} / \mathrm{Fe}]=1$. See text for an explanations concering stars with $[\mathrm{C} / \mathrm{Fe}]<+1$.

Fig. 2. $[\mathrm{X} / \mathrm{Fe}]$ for CEMP stars of this work and from the literature. Symbols are the same as in Fig. 1. 

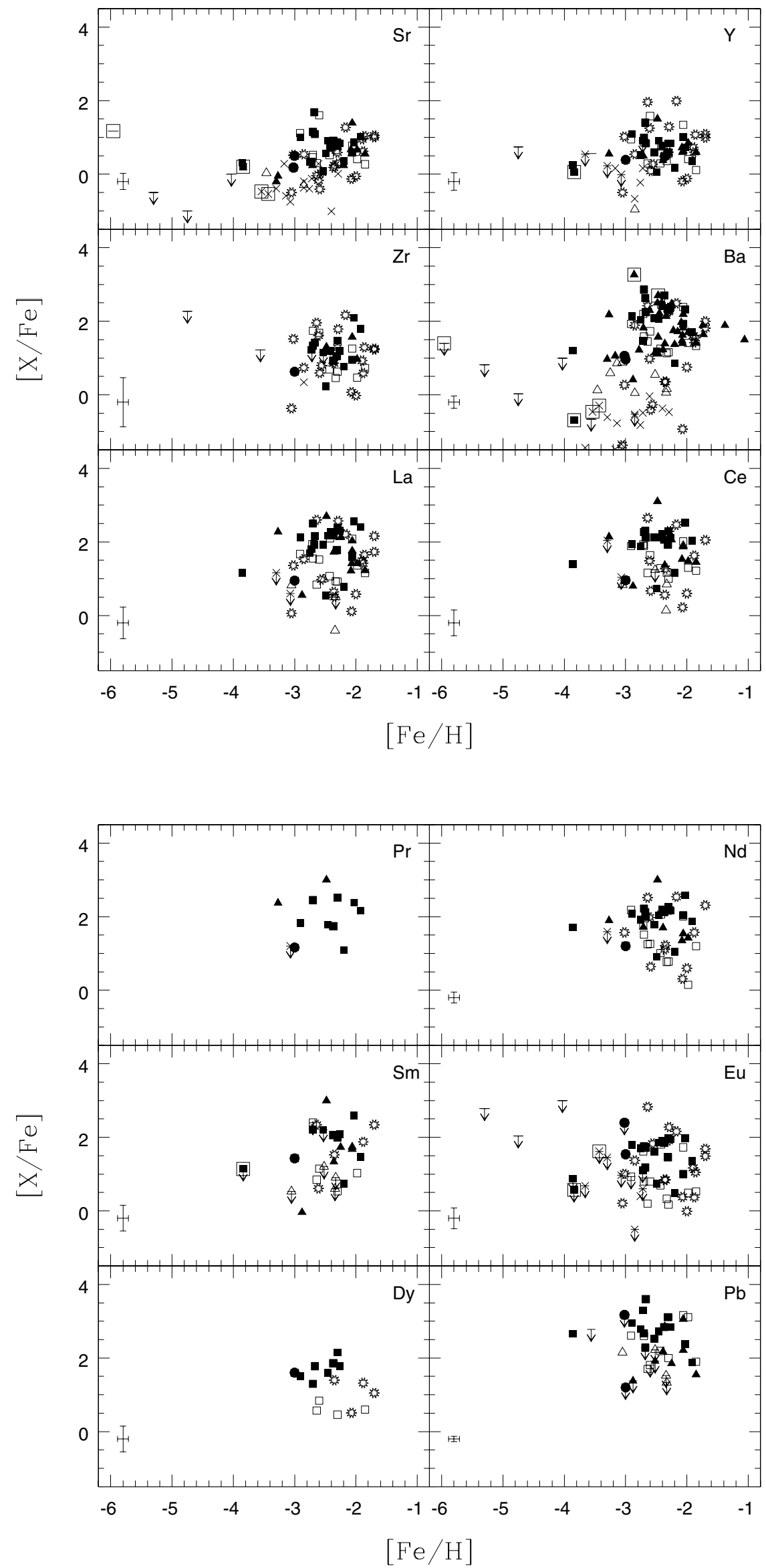

Fig. 3. $[\mathrm{X} / \mathrm{Fe}]$ for CEMP stars of this work and from the literature. Symbols are the same as in Fig. 1.

Fig. 4. $[\mathrm{X} / \mathrm{Fe}]$ for CEMP stars of this work and from the literature. Symbols are the same as in Fig. 1. 
consequence of the primary production of ${ }^{12} \mathrm{C}$ in $\mathrm{He}$ burning and up to but not exceeding an equilibrium amount of ${ }^{13} \mathrm{C}$ (the latter in hydrogen-ingestion via $\left.{ }^{12} \mathrm{C}(\mathrm{p}, \gamma){ }^{13} \mathrm{~N}\left(\beta^{+} v_{\mathrm{e}}\right)^{13} \mathrm{C}\right)$, and the production of $\mathrm{Ba}$ proportionately to ${ }^{13} \mathrm{C}$ through the ${ }^{13} \mathrm{C}(\alpha, \mathrm{n}){ }^{16} \mathrm{O}$ source, in a TP-AGB star whose wind is then transferred to its lower-mass companion forming the CEMP-s and CEMP-r/s binary stars.

As noted by Tsangarides (2005), [Eu/Fe] vs. [C/Fe] exhibits a similar increasing trend (though many stars are missing in this panel compared to the upper one for Ba because they have no Eu abundance available). The upper envelope to $[\mathrm{Eu} / \mathrm{C}]$ may be interpreted in the same way as the maximal s-process $\mathrm{Eu}$ production, alongside $\mathrm{Ba}$, for a given level of ${ }^{12} \mathrm{C}$. There are also many stars known with r-process enhancements but no $\mathrm{C}$-enhancement; the origin of genuine r-process enhancements might well be independent of the process responsible for carbon and nitrogen excesses (e.g., Aoki et al. 2002a; Hansen et al. 2011).

\subsubsection{An upper limit on $[\mathrm{C} / \mathrm{H}]$}

In order for this scenario to have merit, we require primary production of $\mathrm{C}$ in TP-AGB stars, and require this signature to remain even after transfer onto a lower mass companion in an environmental CEMP-star production event. Such evidence already exists, as it has been noted already by Ryan (2003) that the $[\mathrm{C} / \mathrm{Fe}]$ vs. $[\mathrm{Fe} / \mathrm{H}]$ relation of CEMP stars likewise exhibits an upper envelope consistent with $[\mathrm{C} / \mathrm{H}]=$ const., close to zero. This implies that TP-AGB stars may produce up to, but not in excess of, this level of $\mathrm{C}$ irrespective of metallicity across the full metallicity range of halo stars. Precisely this behaviour is seen in the yields of TP-AGB models of Karakas (2002). Specifically, Karakas' carbon yields show that the ejected carbon mass, while strongly dependent on progenitor mass - minimal for stars below $1.5 M_{\odot}$ and peaking for stars around 3 to $4 M_{\odot}-$ are almost independent of metallicity. Karakas presents calculations for $Z=0.020,0.008,0.004$, i.e. over a range of a factor of five, and shows that while the progenitor mass at which the ejected carbon mass peaks does shift slightly - but most importantly the level does not change markedly; in other words ejected carbon is produced as a primary element independent of metallicity. Although these AGB models have a higher metallicity than genuine halo stars, the lack of metallicity sensitivity over this broad range makes it plausible that the carbon is produced in a primary fashion even as metallicity reduces further. In the environmental enrichment scenarios for the production of CEMP stars, the progenitor-mass dependence of ejected carbon mass and the various accretion geometries will ensure that recipient stars achieve a range of accreted carbon masses, and hence a range of $[\mathrm{C} / \mathrm{Fe}]$ values, but the metallicity independence of the ejected carbon mass, and the presumed metallicity independence of the accretion mass, will ensure there is no metallicity dependence of $[\mathrm{C} / \mathrm{H}]$, thus providing an explanation for the upper envelope for $[\mathrm{C} / \mathrm{H}]$ seen in the population of CEMP stars. A prediction coming from this interpretation, which may be testable given larger samples in the future, is that CEMP stars formed by other, non-AGB, mechanisms need not be restricted by this limit.

\subsubsection{Classification of CEMP-s stars}

Figures $6 \mathrm{a}$ and $\mathrm{b}$ show the relationship between $\mathrm{Fe}, \mathrm{Ba}$ and $\mathrm{Eu}$. Figure $6 \mathrm{~b}$ indicates the conventional CEMP classification boundaries. CEMP stars exhibiting large over-abundances of the s-process elements, with $[\mathrm{Ba} / \mathrm{Fe}]>+1$ and $[\mathrm{Ba} / \mathrm{Eu}]>+0.5$, are CEMP-s, and are represented by the open squares in Figs. 1 to 4. The environmental scenario suggested for their neutron-capture element enrichment involves mass transfer in a binary system. The initially more massive star evolves first and enters the TPAGB phase, where it convectively enriches its atmosphere with s-process products. After a phase of strong mass loss through a stellar wind, it becomes a white dwarf, and now the former secondary presents in its atmosphere vestiges of the nucleosynthesis of the previous TP-AGB star. Nineteen stars from the literature were found in our search to be in this class. Two stars of our sample (BS 16077-077 and CS 29512-073) might be CEMP-s (Fig. 6a). Although the Ba abundance of BS 16077077 is not so high $([\mathrm{Ba} / \mathrm{Fe}]=+0.75)$, the low Eu abundance $([\mathrm{Eu} / \mathrm{Fe}]=-0.01)$ increases the ratio $[\mathrm{Ba} / \mathrm{Eu}]$. This star is close to the line $[\mathrm{Eu} / \mathrm{Fe}] \sim 0$ in panel (b).

\subsubsection{Classification of CEMP-r and CEMP-no stars}

The CEMP stars that exhibit $[\mathrm{Ba} / \mathrm{Eu}]<0$ are referred to as CEMP-r. As an example, the mean values for the star CS 22892-052 (McWilliam et al. 1995; Norris et al. 1997; Sneden et al. 2003; Honda et al. 2004; Barklem et al. 2005) are: $[\mathrm{Eu} / \mathrm{Fe}]=+1.54$ and $[\mathrm{Ba} / \mathrm{Fe}]=+0.96$, resulting in $[\mathrm{Ba} / \mathrm{Eu}]=-0.59$ (see Tables B.3 and B.4). Cohen et al. (2006) reported a very high value of the $\mathrm{Eu}$ abundance for the star HE 1410-0004, so this star is likely the second CEMP-r star found in the literature. It is worth noting, however, that their high Eu abundance is only an upper limit $([\mathrm{Eu} / \mathrm{Fe}]<+2.40)$, and therefore, only a lower limit in $[\mathrm{Ba} / \mathrm{Eu}]>-1.34$, can be inferred. These two stars are represented by circles in the figures.

Results from Hansen et al. (2011) support the hypothesis that r-process enhancement is not coupled with the presence of a binary companion, and suggests that where it is found to occur, it must have originated in separate pollution events of the natal molecular clouds from which CEMP-r stars formed. It is worth noting that CS 22892-052 is included in the sample of r-process enhanced stars that received extensive radial-velocity monitoring in the work of Hansen et al. (2011). They report that this star appears not to be a binary, despite the earlier suggestion by Preston \& Sneden (2001), indicating that its C content was not produced by a companion. Thus, membership in a binary system appears to be decoupled from details associated with these particular abundance variations.

The CEMP stars with $[\mathrm{Ba} / \mathrm{Fe}]<0$ were called CEMP-no by Ryan et al. (2005). However, some of the stars in the literature with $[\mathrm{Ba} / \mathrm{Fe}]<0$ might be CEMP-r, rather than CEMP-no, if $[\mathrm{Eu} / \mathrm{Fe}]>+1$. Since some of them have no $\mathrm{Eu}$ abundance available, they could not be classified accordingly.

Five stars of this work have $[\mathrm{Ba} / \mathrm{Eu}]<0$, the region of CEMP-no and CEMP-r, where two of them are below the dashed line in Fig. 6a, which represents the production of $\mathrm{Ba}$ only through the r-process, $[\mathrm{Ba} / \mathrm{Eu}] \sim-0.7$ (Mashonkina \& Gehren 2001). One of them (BS 16033-081), might be called CEMP-no, since its $[\mathrm{Ba} / \mathrm{Fe}]<0$, whereas the other (BS 16929-005) might be CEMP-r, since $[\mathrm{Ba} / \mathrm{Fe}] \sim 0^{7}$ and $[\mathrm{Eu} / \mathrm{Fe}]>+1$. If no Eu abundance is given, one may classify this star as CEMP-no. Two stars with $[\mathrm{Ba} / \mathrm{Fe}] \sim+0.35$ (BS 15621-047, BS 16543-097) might be CEMP-r, since $[\mathrm{Ba} / \mathrm{Eu}]<0$ for both and $[\mathrm{Eu} / \mathrm{Fe}] \sim+1$. The last star, CS 31070-073, has the highest value of [Eu/Fe], even higher than the ones from the literature referred to as CEMP-r (see filled

\footnotetext{
Honda et al. (2004) and Aoki et al. (2007) determined a very low value of [Ba/Fe] for BS 16929-005, as can be seen in Table 10 .
} 

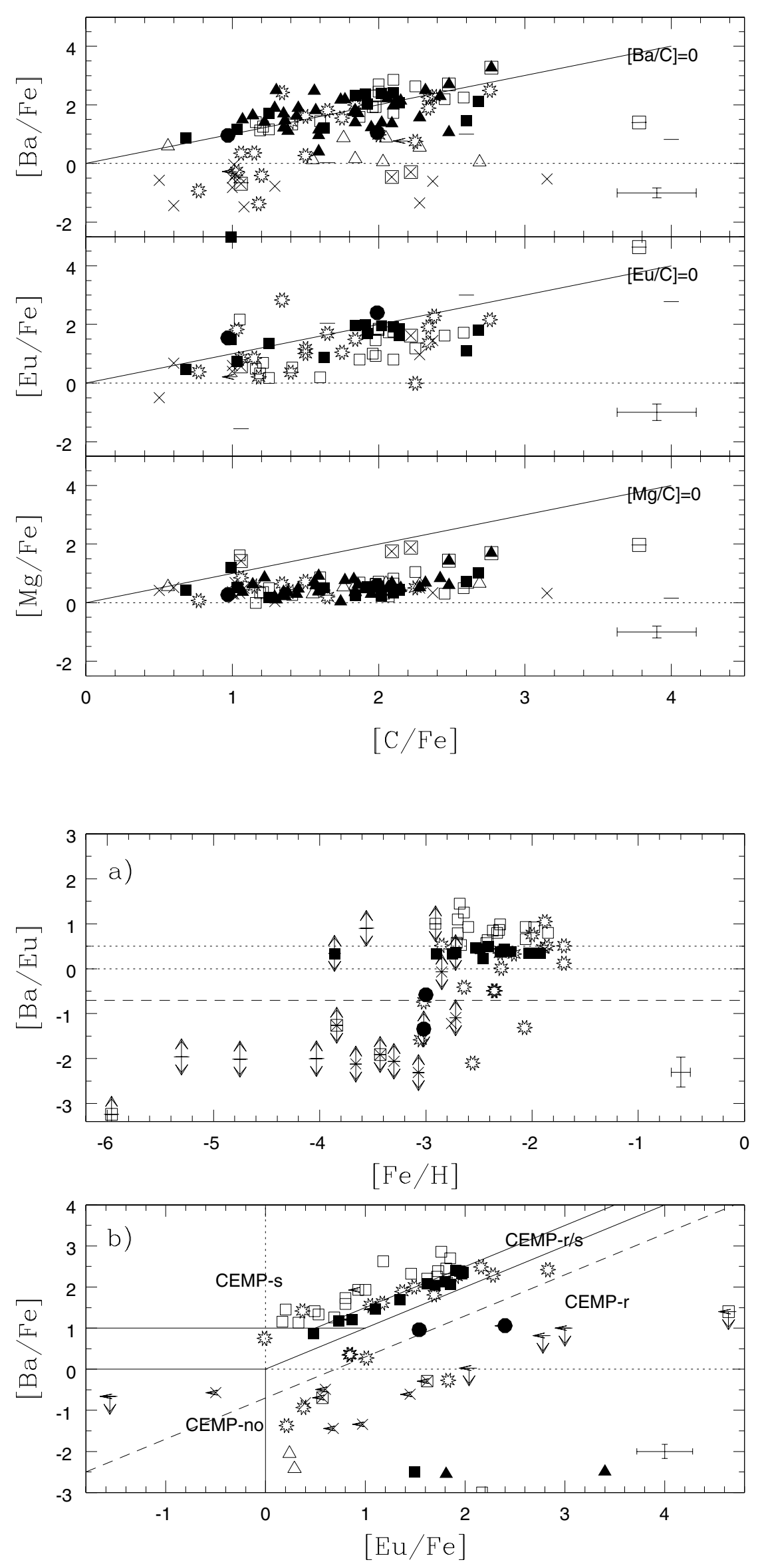

Fig. 5. $[\mathrm{Mg}, \mathrm{Eu}, \mathrm{Ba} / \mathrm{Fe}]$ vs. $[\mathrm{C} / \mathrm{Fe}]$ for $\mathrm{CEMP}$ stars of this work and from the literature. Fiducial lines $[\mathrm{Ba}, \mathrm{Eu}, \mathrm{Mg} / \mathrm{C}]=0$ are drawn for convenience. Symbols are the same as in Fig. 1. The arrows toward left indicate upper limit for $[\mathrm{C} / \mathrm{Fe}]$.

Fig. 6. CEMP stars from the literature and this work with the same symbols as in Fig. 1. a) $[\mathrm{Ba} / \mathrm{Eu}]$ vs. $[\mathrm{Fe} / \mathrm{H}]$. The dotted lines are the limits of the range for CEMP-r/s and the dashed line is the limit for the r-process only, $[\mathrm{Ba} / \mathrm{Eu}]=-0.7$. The arrows up and down indicate upper limit for $[\mathrm{Eu} / \mathrm{Fe}]$ and $[\mathrm{Ba} / \mathrm{Fe}]$, respectively. b) $[\mathrm{Ba} / \mathrm{Fe}]$ vs. $[\mathrm{Eu} / \mathrm{Fe}]$. Dashed line indicates $[\mathrm{Ba} / \mathrm{Eu}]=-0.7$, and dotted lines indicate where $[\mathrm{Ba} / \mathrm{Fe}]=0$ and $[\mathrm{Eu} / \mathrm{Fe}]=0$; CEMP-s and CEMP-r/s share instinctively the limits $[\mathrm{Ba} / \mathrm{Fe}]>0$ and $[\mathrm{Ba} / \mathrm{Fe}]=[\mathrm{Eu} / \mathrm{Fe}]$, whereas CEMP-no are inside the limits $[\mathrm{Ba} / \mathrm{Fe}]$ and $[\mathrm{Eu} / \mathrm{Fe}]<0$ and CEMP-r inside $[\mathrm{Eu} / \mathrm{Fe}]>0$ and $[\mathrm{Ba} / \mathrm{Fe}]=[\mathrm{Eu} / \mathrm{Fe}]$. The arrows toward left and down indicate upper limit for $[\mathrm{Eu} / \mathrm{Fe}]$ and $[\mathrm{Ba} / \mathrm{Fe}]$, respectively. 


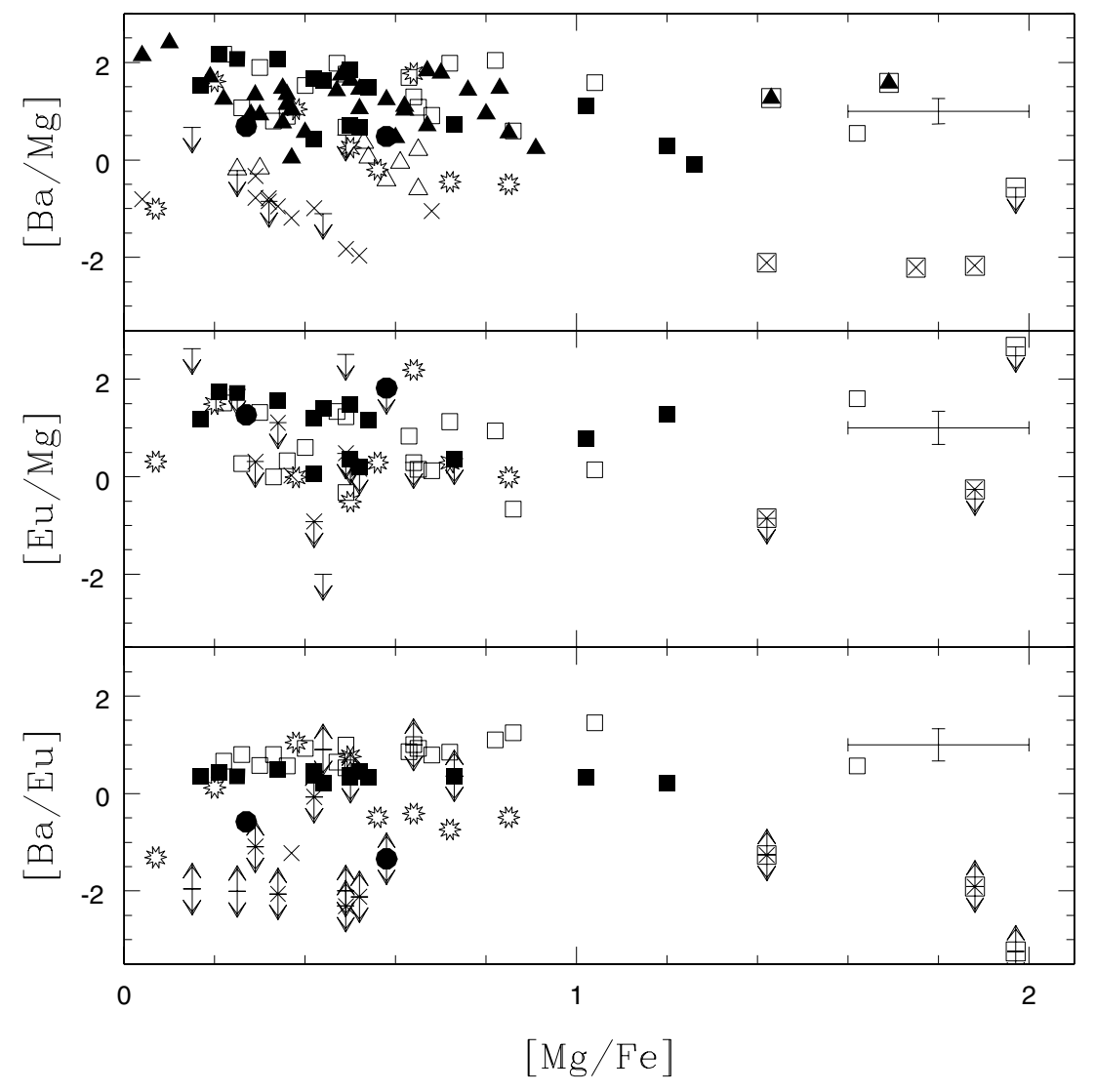

Fig. 7. The behaviour of $\mathrm{Mg}, \mathrm{Ba}$ and $\mathrm{Eu}$ abundances for CEMP stars of this work and from the literature. Symbols are the same as in Fig. 1. circles in Fig. 6b). [Ba/Eu] is very low, even though $[\mathrm{Eu} / \mathrm{Fe}]$ and $[\mathrm{Ba} / \mathrm{Fe}]$ are high, suggesting that it might be CEMP-r/s.

\subsubsection{Classification of CEMP-r/s stars}

For CEMP stars with $0<[\mathrm{Ba} / \mathrm{Eu}] \lesssim+0.5$, both r-process and s-process enhancements have been inferred (Hill et al. 2000; Wanajo et al. 2006). Fifteen CEMP stars corresponding to this description were found in the literature so far, and are referred to as CEMP-r/s (or variations). Cohen et al. (2003) was the first group to propose that the origin of CEMP-r/s stars includes two mass transfers - the first one would result in the enrichment of s-process (from an AGB member of a binary system), while the second would involve a so-called accretion-induced collapse (AIC), as proposed by Qian \& Wasserburg (2003), at which time the r-process enrichment would occur. After those events, the survivor star would be observed as a CEMP-r/s star. Qian \& Wasserburg (2001) commented on the possibility that stars like CS 31082-001, which is r-process rich (but not C-rich), has survived the SN II explosion of its companion and now has a compact companion, most likely a black hole.

Three stars in the present work have ratios in the range $0<[\mathrm{Ba} / \mathrm{Eu}]<+0.5$, the CEMP-r/s zone represented in Fig. 6b: CS 29503-010, CS 29526-110, and CS 29528-028. One of them, CS 29526-110, was similarly classified as CEMP-r/s by Aoki et al. (2002d), but the other two are being classified for the first time, since Aoki and collaborators did not determine their Eu abundances (see Table 10).

Ivans et al. (2005) have derived abundances for CS 29497030, and compared their results to theoretical models of neutroncapture processes at low metallicity, both with and without preenrichment of the initial abundances. In the pre-enrichment in r-elements case, the heavy-element isotopes act as strong poisons for the neutron exposure, competing with $\mathrm{Fe}$ and decreasing s-process efficiency.

Ivans et al. (2005) claim that CS 29497-030 could be classified as CEMP-r/s, since their abundance ratios are best fitted by a pre-enrichment of r-process material out of which the binary system formed. However, Ivans et al. (2005) derived values 0.15 dex and 0.55 dex higher than Sivarani et al. (2004) for $[\mathrm{Ba} / \mathrm{Fe}]$ and $[\mathrm{Eu} / \mathrm{Fe}]$, respectively. The Sivarani et al. $[\mathrm{Eu} / \mathrm{Fe}]$ is better fitted by the model without pre-enrichment in Fig. 2 of Ivans et al. Therefore, Sivarani et al. (2004) would classify as CEMP-s; the same situation pertains if the classification comes from the average of the two works, as shown in Table B.1.

Although the CEMP-r/s classification has been widely used, we suggest (following Tsangarides 2005) that it is a superfluous class, and that there is no physical distinction between CEMP-s and CEMP-r/s stars, other than the arbitrary choice of the $[\mathrm{Ba} / \mathrm{Eu}]$ boundary. The $\mathrm{r} / \mathrm{s}$ classification was motivated by a belief that the high $[\mathrm{Eu} / \mathrm{Fe}]$ values and intermediate $[\mathrm{Ba} / \mathrm{Eu}]$ values must signify Eu production by the r-process in a site distinct from the one where $\mathrm{Ba}$ was produced via the s-process. However, CEMP-s stars are able to produce quite high $[\mathrm{Eu} / \mathrm{Fe}]$ values, easily up to +2.0 (see Table B.4). The reasonable conclusion is that Eu production, although r-process dominated in the Solar System, is readily achievable by the s-process alone. Three further arguments strengthen this view. First, if Eu production and $\mathrm{Ba}$ production in CEMP-r/s stars is genuinely decoupled into separate $\mathrm{r}$ - and s-processes, it is astonishing how remarkably tight the correlation between $[\mathrm{Ba} / \mathrm{Fe}]$ and $[\mathrm{Eu} / \mathrm{Fe}]$ for CEMP-s and CEMP-r/s stars appears in Fig. 6b. Two separate processes would naturally be expected to provide more diverse outcomes. Secondly, Fig. 5 shows that the upper envelope of $[\mathrm{Eu} / \mathrm{Fe}]$ in 
CEMP stars closely corresponds to $[\mathrm{Eu} / \mathrm{C}]=0$. That is, irrespective of the degree of the C over-abundance in CEMP stars, Eu production is coupled to that value, at least as an upper bound. The r-process, occurring presumably in the final stage of evolution of these stars' progenitors, should not be expected to follow the $\mathrm{C}$ abundance so closely. Thirdly, we note that high Eu abundances are found in Pop. I Ba stars, where the r-process is not believed to be active at all (Allen \& Barbuy 2006). For the CEMP stars, a more reasonable view (and certainly the view more consistent with Occam's razor) is that only one process is responsible for the production of both $\mathrm{Ba}$ and $\mathrm{Eu}$ in lockstep with $\mathrm{C}$, and that process is the s-process, not a tuned balance between s- and r-processes under widely different physical conditions and at different phases of stellar evolution.

\subsubsection{Eu detections}

Our search for data from the literature reveals that the nucleosynthetic record is seriously incomplete, particularly with respect to elements associated with the r-process. About $67 \%$ of CEMP stars have no measured Eu abundance (or only an upper limit); this makes the abundance pattern of many stars unclear. The lack of Eu abundances becomes clear in Fig. 7 through the open and filled triangles, which represent stars for which there is no published abundance for Eu. The missing crosses from one panel to another in Fig. 7 also illustrate the lack of Eu for CEMP stars with $[\mathrm{Ba} / \mathrm{Fe}]<0$. For some stars, only an upper limit was published either for $\mathrm{Eu}$ and $\mathrm{Ba}$; these stars are represented by dashes in Figs. 1 to 6. This work has provided Eu abundances for fifteen stars, only four of which had a previous determination (see Table 10). For two stars of our sample it was not possible to determine a $\mathrm{Eu}$ abundance, and for one, only an upper limit could be estimated. Masseron et al. (2010) compiled abundances from analyses of high-resolution spectra of metal-poor stars, including C-rich stars. However, their suggestions of classifications for CEMP stars was hampered due to the absence of Eu detection for many stars. The difficulty in determining $\mathrm{Eu}$ abundances resides in the fact that its lines in CEMP stars are very weak, so higher-quality spectra than have been obtained to date are required (which in turn require long exposure times on large telescopes). So, more research programs dedicated to the investigation of Eu in CEMP stars, using new high-resolution spectrographs on large telescopes, are needed to make further progress in understanding the nucleosynthetic processes that took place in the early Galaxy.

\section{Conclusions}

We have presented a detailed analysis of the elemental abundances for a sample of 18 CEMP stars, based on high-resolution spectroscopic data, and together with data from the literature, examined the behaviour of their abundance ratios. Some stars exhibit large over-abundances of $\mathrm{O}, \mathrm{Na}, \mathrm{Mg}$, and $\mathrm{Si}$ : 3 stars are Si-rich; these 3 plus an additional 4 stars are Mg-rich; these 7 plus 4 additional stars are Na-rich. Ten stars, including some of these $11 \mathrm{Na}$-rich stars for which oxygen abundances were available, are O-rich. These results are in agreement with the fallback hypothesis (Turatto et al. 1998; Zampieri et al. 2003). However, stronger conclusions must await suitable data from which $\mathrm{O}$ abundances for all of these stars can be derived.

This work has shown that the lack of accurate Eu abundances has made the abundance pattern of many CEMP stars quite unclear. Once we have better available data, it will be possible to perform an accurate detailed analysis, allowing an improvement in our understanding of the astrophysical origins of the different classes of CEMP stars. Observing lines of Eu and other elements usually associated with the r-process would indicate the true extent of the r-process. Notwithstanding the relative paucity of Eu data, we contend on the basis of available $\mathrm{C}, \mathrm{Ba}$, and Eu abundances that the hybrid CEMP-r/s class is superfluous, and arises because of incomplete knowledge of Eu production by the s-process at low metallicity. As a result, stars labeled as CEMP-r/s have the same origin as CEMP-s stars. On the other hand, the presence of r-process elements CEMP-r stars may well be due to previous pollution of the molecular clouds from which they formed.

Acknowledgements. D.M.A. acknowledges the University of Hertfordshire, where part of this work was developed. D.M.A. also acknowledges a CAPES post-doctoral fellowship No. BEX 3448/06-1, as well as FAPESP, for the postdoctoral fellowship No. 2008/01265-0, and CNPq, for the post-doctoral fellowship No. 150370/2012-1. We are gratefull to Fiorella Castelli for her prompt help concerning the codes ATLAS9, WIDTH9 and SYNTHE. T.C.B. acknowledges partial funding of this work from grants PHY 02-16783 and PHY 0822648: Physics Frontier Center/Joint Institute for Nuclear Astrophysics (JINA), awarded by the US National Science Foundation. S.R. thanks the partial support from FAPESP, CNPq, and CAPES. We acknowledge the anonymous referee for help in improving the error analysis.

\section{Appendix A: Uncertainty calculations}

Uncertainties on abundances were evaluated by consideration of the degree to which a variation of $1 \sigma$ in the atmospheric parameters (including macroturbulence for the SAT subsample) and the $\mathrm{S} / \mathrm{N}$ (only for the DMA subsample) affects the output value of the synthesis routine. Table A.1 shows the systematic effects that estimated errors in the adopted atmospheric parameters have on abundances $(\log \epsilon(\mathrm{X}))$.

For the DMA subsample, the star BS 16543-097 was used as a reference to calculate uncertainties, since it has a similar temperature as many of the other stars. One line of each element was chosen to calculate the effects that errors on atmospheric parameters have on our derived abundances; these were then extended to all other lines of the same element.

Extending the results on uncertainties computed for one line to the other lines of the same element is not actually the best procedure. Different lines (i.e., lines with different EPs, strengths, etc.) may have different dependences on the stellar parameters. In fact, the ideal procedure would be to compute all variations for all lines. However, it is impractical using spectrum synthesis, due to the very long time that it would take, since each variation requires the complete "ritual" of the full spectrum synthesis. However, if one chooses a suitable line as a proxy for the remaining lines, it is valid to estimate the variations due the atmospheric and experimental parameters for this line, and to assume that this variation is representative for all other lines of the same element. The profile of this line must to be as well-defined as possible - not too strong, not too weak, in order to make the line representative.

To determine the uncertainties on abundances, we followed Johnson (2002); a portion of this procedure and formulae are rewritten below. Then, the variance in $\log \epsilon(\mathrm{X})$ can be written as

$$
\begin{aligned}
& \sigma_{\log \epsilon}^{2}=\sigma_{\text {rand }}^{2}+\left(\frac{\partial \log \epsilon}{\partial T}\right)^{2} \sigma_{T}^{2}+\left(\frac{\partial \log \epsilon}{\partial \log g}\right)^{2} \sigma_{\log g}^{2}+\left(\frac{\partial \log \epsilon}{\partial \xi}\right)^{2} \sigma_{\xi}^{2} \\
& +2\left[\left(\frac{\partial \log \epsilon}{\partial T}\right)\left(\frac{\partial \log \epsilon}{\partial \log g}\right) \sigma_{T \log g}\right]+2\left[\left(\frac{\partial \log \epsilon}{\partial \xi}\right)\left(\frac{\partial \log \epsilon}{\partial \log g}\right) \sigma_{\log g \xi}\right] \\
& \quad+2\left[\left(\frac{\partial \log \epsilon}{\partial \xi}\right)\left(\frac{\partial \log \epsilon}{\partial T}\right) \sigma_{\xi T}\right]
\end{aligned}
$$


where $\sigma_{\text {rand }}^{2}$ is the difference between the determined abundance for one line found through the best fit and that found after adding $(\mathrm{S} / \mathrm{N})^{-1}$ to it. The term $(\mathrm{S} / \mathrm{N})^{-1}$ comes from the inverse relation between $\mathrm{S} / \mathrm{N}$ and the difference of the observed fluxes and the synthetic spectrum used to determine the abundance of a line. The $\mathrm{S} / \mathrm{N}$ shown in Table 3 were measured in a window around $\lambda 4500 \AA$. The partial derivatives $(\partial \log \epsilon / \partial T),(\partial \log \epsilon / \partial \log g)$, and $(\partial \log \epsilon / \partial \xi)$ were determined by varying $1 \sigma$ on the model atmosphere for the star BS 16543-097, as explained above.

The covariances $\sigma_{T \log g}, \sigma_{\log g \xi}$, and $\sigma_{\xi T}$ also were determined using the star BS 16543-097. We picked 11 values for temperature from $-1 \sigma$ to $+1 \sigma$, and created model atmospheres with several values of $\log g$ to force ionization balance. Then, the covariance between $T$ and $\log g$ is

$\sigma_{T \log g}=\frac{1}{N} \sum_{i=1}^{N}\left(T_{i}-T_{m}\right)\left(\log g_{i}-\log g_{m}\right)$,

where $T_{m}$ and $\log g_{m}$ are the adopted temperature and $\log g$ for the star. The correlation coefficient is defined as

$\rho(T, \log g)=\frac{\sigma_{T \log g}}{\sigma_{T} \sigma_{\log g}}$,

where in this case, $\sigma_{T}$ and $\sigma_{\log g}$ are the standard deviation for $T$ and $\log g$, taking into account the 11 values mentioned above. We found $\sigma_{T \log g}=3.06$ and $\rho(T, \log g)=1.02$, indicating a strong correlation between $T$ and $\log g$. We performed a similar calculation to determine $\sigma_{\log g \xi}=-0.00062$ and correlation $\rho(\log g \xi)=-0.8197$, indicating that $\log g$ and $\xi$ are highly correlated, although less so than for $T$ and $\log g$. Similarly to Johnson (2002), $\sigma_{\xi T}$ was found to be negligible, and $\sigma_{T \log g}$, the strongest correlation.

Considering the ratio of two elements $\mathrm{A}$ and $\mathrm{B}$, its error is

$\sigma^{2}(\mathrm{~A} / \mathrm{B})=\sigma_{\mathrm{A}}^{2}+\sigma_{\mathrm{B}}^{2}-2 \sigma_{\mathrm{A}, \mathrm{B}}$,

where the covariance between two abundances is given by

$$
\begin{aligned}
\sigma_{\mathrm{A}, \mathrm{B}} & =\left(\frac{\partial \log \epsilon_{\mathrm{A}}}{\partial T}\right)\left(\frac{\partial \log \epsilon_{\mathrm{B}}}{\partial T}\right) \sigma_{T}^{2}+\left(\frac{\partial \log \epsilon_{\mathrm{A}}}{\partial \log g}\right)\left(\frac{\partial \log \epsilon_{\mathrm{B}}}{\partial \log g}\right) \sigma_{\log g}^{2} \\
& +\left(\frac{\partial \log \epsilon_{\mathrm{A}}}{\partial \xi}\right)\left(\frac{\partial \log \epsilon_{\mathrm{B}}}{\partial \xi}\right) \sigma_{\xi}^{2} \\
& +\left[\left(\frac{\partial \log \epsilon_{\mathrm{A}}}{\partial T}\right)\left(\frac{\partial \log \epsilon_{\mathrm{B}}}{\partial \log g}\right)+\left(\frac{\partial \log \epsilon_{\mathrm{A}}}{\partial \log g}\right)\left(\frac{\partial \log \epsilon_{\mathrm{B}}}{\partial T}\right)\right] \sigma_{T \log g} \\
& +\left[\left(\frac{\partial \log \epsilon_{\mathrm{A}}}{\partial \xi}\right)\left(\frac{\partial \log \epsilon_{\mathrm{B}}}{\partial \log g}\right)+\left(\frac{\partial \log \epsilon_{\mathrm{A}}}{\partial \log g}\right)\left(\frac{\partial \log \epsilon_{\mathrm{B}}}{\partial \xi}\right)\right] \sigma_{\log g \xi}
\end{aligned}
$$

Table 8 includes uncertainties on DMA subsample, while the last column in Table A.1 shows the estimate uncertainties for the SAT subsample.

\section{References}

Akerman, C. J., Carigi, L., Nissen, P. E., Pettini, M., \& Asplund, M. 2004, A\&A, 414, 931

Allen, D. M., \& Barbuy, B. 2006, A\&A, 454, 917

Alonso, A., Arribas, S., \& Martinez-Roger, C. 1995, A\&A, 297, 197

Alonso, A., Arribas, S., \& Martinez-Roger, C. 1996a, A\&A, 313, 873

Alonso, A., Arribas, S., \& Martinez-Roger, C. 1996b, A\&AS, 117, 227

Alonso, A., Arribas, S., \& Martinez-Roger, C. 1998, A\&AS, 131, 209

Alonso, A., Arribas, S., \& Martinez-Roger, C. 1999, A\&AS, 140, 261

Aoki, W., Norris, J. E., Ryan, S. G., Beers, T. C., \& Ando, H. 2000, ApJ, 536, L97

Aoki, W., Ryan, S. G., Norris, J. E., et al. 2001, ApJ, 561, 346
Aoki, W., Norris, J. E., Ryan, S. G., Beers, T. C., \& Ando, H. 2002a, ApJ, 567, 1166

Aoki, W., Norris, J. E., Ryan, S. G., Beers, T. C., \& Ando, H. 2002b, ApJ, 576, L141

Aoki, W., Norris, J. E., Ryan, S. G., Beers, T. C., \& Ando, H. 2002c, PASJ, 54, 933

Aoki, W., Ryan, S. G., Norris, J. E., et al. 2002d, ApJ, 580, 1149

Aoki, W., Ando, H., Honda, S., et al. 2002e, PASJ, 54, 427

Aoki, W., Norris, J. E., Ryan, S. G., et al. 2004, ApJ, 608, 971

Aoki, W., Bisterzo, S., Gallino, R., et al. 2006a, ApJ, 650, L127

Aoki, W., Frebel, A., Christlieb, N., et al. 2006b, ApJ, 639, 897

Aoki, W., Beers, T. C., Christlieb, N., et al. 2007, ApJ, 655, 492

Aoki, W., Beers, T. C., Sivarani, T., et al. 2008, ApJ, 678, 1351

Arlandini, C., Käppeler, F., \& Wisshak, K. 1999, ApJ, 525, 886

Barbuy, B., Spite, M., Spite, F., et al. 2005, A\&A, 429, 1031

Barklem, P. S., Christlieb, N., Beers, T. C., et al. 2005, A\&A, 439, 129

Beers, T. C., \& Christlieb, N. 2005, ARA\&A, 43, 531

Beers, T. C., Preston, G. W., \& Shectman, S. A. 1985, AJ, 90, 2089

Beers, T. C., Preston, G. W., \& Shectman, S. A. 1992, AJ, 103, 1987

Beers, T. C., Bestman, W., \& Wilhelm, R. 1994, AJ, 108, 268

Beers, T. C., Sivarani, T., Marsteller, B., et al. 2007, AJ, 133, 1193

Behara, N. T., Bonifacio, P., Ludwig, H.-G., et al. 2010, A\&A, 513, A72

Bell, R. A., Eriksson, K., Gustafsson, B., \& Nordlund, A. 1976, A\&AS, 23, 37 Bergstrom, H., Biémont, E., Lundberg, H., \& Persson, A. 1988, A\&A, 192, 337 Bessell, M. S. 1979, PASP, 91, 589

Bessell, M. S., Castelli, F., \& Plez, B. 1998, A\&A, 333, 231

Biehl, D. 1976, Ph.D. Thesis, Kiel University

Bielski, A. 1975, JQSRT, 15, 463

Biémont, E., \& Godefroid, M. 1980, A\&A, 84, 361

Biémont, E., \& Lowe, R. M. 1993, A\&A, 273, 665

Biémont, E., Grevesse, N., Hannaford, P., \& Lowe, R. M. 1981, ApJ, 248, 867

Biémont, E., Grevesse, N., Hannaford, P., \& Lowe, R. M. 1989, A\&A, 222, 307

Bisterzo, S., Gallino, R., Straniero, O., Cristallo, S., \& Käppeler, F. 2010, MNRAS, 404, 1529

Caffau, E., Bonifacio, P., François, P., et al. 2011, nature, 477, 67

Carollo, D., Beers, T. C., Bovy, J., et al. 2012, ApJ, 744, 195

Carpenter, J. M. 2001, AJ, 121, 2851

Castelli, F. 2004, Mem. S. A. It, 1, 1

Castelli, F., \& Kurucz, R. L. 2004 [arXiv: astro-ph/0405087v1]

Castelli, F., Gratton, R. G., \& Kurucz, R. L. 1997, A\&A, 318, 841

Christlieb, N., Bessell, M. S., Beers, T. C., et al. 2002, Nature, 419, 904

Christlieb, N., Gustafsson, B., Korn, A. J., et al. 2004, ApJ, 603, 708

Christlieb, N., Schörck, T., Frebel, A., et al. 2008, A\&A, 484, 721

Cohen, J. G., Christlieb, N., Qian, Y.-Z., \& Wasserburg, G. J. 2003, ApJ, 588, 1082

Cohen, J. G., McWilliam, A., Shectman, S., et al. 2006, AJ, 132, 137

Cohen, J. G., Christlieb, N., McWilliam, A., et al. 2008, AJ, 672, 320

Cooke, R., Pettini, M., Steidel, C. C., Rudie, G. C., \& Nissen, P. E. 2011 , MNRAS, 417, 1534

Corliss, C. H., \& Bozman, W. R. 1962, Experimental Transition Probabilities for Spectral Lines of Seventy Elements, NBS Monograph 32 (Washington: GPO) Cottrell, P. L., \& Norris, J. 1978, ApJ, 221, 893

Cram, L. 1999, Transactions of the International Astronomical Union, Vol. XXIIIB, ed. J. Andersen, 141

Demarque, P., Woo, J.-H., Kim, Y., \& Yi, S. K. 2004, ApJS, 155, 667

Depagne, E., Hill, V., Spite, M., et al. 2002, A\&A, 390, 187

Frebel, A., Aoki, W., Christlieb, N., et al. 2005, Nature, 434, 871

Frebel, A., Norris, J. E., Aoki, W., et al. 2007, ApJ, 658, 534

Frebel, A., Collet, R., Eriksson, K., Christlieb, N., \& Aoki, W. 2008, ApJ, 684, 588

Fuhr, J. R., \& Wiese, W. L. 2006, J. Phys. Chem. Ref. D., 35, 4

Fuhr, J. R., Martin, G. A., \& Wiese, W. L. 1988, J. Phys. Chem. Ref. Data, 17, Supplement 4 (Washington: US Government Printing Office)

Fuhrmann, K., Axer, M., \& Gehren, T. 1995, A\&A, 301, 492

Fujimoto, M. Y., Ikeda, Y., \& Iben, I. Jr. 2000, ApJ, 529, L25

Giridhar, S., Lambert, D. L., Gonzalez, G., \& Pandey, G. 2001, PASP, 113, 519

Goswami, A., \& Aoki, W. 2010, MNRAS, 404, 253

Goswami, A., Aoki, W., Beers, T. C., et al. 2006, MNRAS, 372, 343

Gratton, R. G., \& Sneden, C. 1994, A\&A, 287, 927

Green, E. M., Demarque, P., \& King, C. R. 1987, in The revised Yale isochrones and luminosity functions (New Haven: Yale Observatory)

Grevesse, N., \& Sauval, A. J. 1998, Space Sci. Rev., 85, 161

Hakkila, J., Myers, J. M., Stidham, B. J., \& Hartmann, D. H. 1997, AJ, 114, 2043

Hannaford, P., \& Lowe, R. M. 1983, Opt. Eng., 22, 532

Hannaford, P., Lowe, R. M., Grevesse, N., Biémont, E., \& Whaling, W. 1982, ApJ, 261, 736

Hansen, T., Andersen, J., Nordström, B., Buchave, L. A., \& Beers, T. C. 2011, ApJ, 743, L1 
Hartog, E. A. D., Lawler, J. E., Sneden, C., \& Cowan, J. J. 2003, ApJS, 148, 543 Herwig, F. 2005, ARA\&A, 43, 435

Hill, V., Barbuy, B., Spite, M., et al. 2000, A\&A, 353, 557

Hirschi, R. 2007, A\&A, 461, 571

Hirschi, R., et al. 2006, RvMA, 19, 101

Honda, S., Aoki, W., Kajino, T., et al. 2004, ApJ, 607, 474

Ito, H., Aoki, W., Honda, S., \& Beers, T. C. 2009, ApJ, 698, L37

Ivans, I. I., Sneden, C., Gallino, R., Cowan, J. J., \& Preston, G. W. 2005, ApJ, 627, L145

Johnson, J. A. 2002, ApJS, 139, 219

Johnson, J. A., \& Bolte, M. 2002, ApJ, 579, L87

Johnson, J. A., \& Bolte, M. 2004, ApJ, 605, 462

Jonsell, K., Barklem, P. S., Gustafsson, B., et al. 2006, A\&A, 451, 651

Karakas, A. I. 2002, Ph.D. Thesis, Monash University

Kim, Y., Demarque, P., Yi, S. K., \& Alexander, D. R. 2002, ApJS, 143, 499

Kipper, T., \& Jorgensen, U. G. 1994, A\&A, 290, 148

Kobayashi, C., Tominaga, N., \& Nomoto, K. 2011, ApJ, 730, L14

Korn, A. J., Richard, O., Mashonkina, L., et al. 2009, ApJ, 698, 410

Kupka, F., Piskunov, N. E., Ryabchikova, T. A., Stempels, H. C., \& Weiss, W. W. 1999, A\&AS, 138, 119

Kupka, F., Ryabchikova, T. A., Piskunov, N. E., Stempels, H. C., \& Weiss, W. W. 2000, Balt. Astron., 9, 590

Kurucz, R. L. 1992, IAUS, 149, 225

Kurucz, R. L. 1993, ATLAS9 Stellar Atmosphere Programs and $2 \mathrm{~km} \mathrm{~s}^{-1}$ grid, Kurucz CD-ROM No. 13

Kurucz, R. L., \& Furenlid, I. 1979, SAO Special Report 387 Sample Spectral Atlas for Sirius

Kurucz, R. L., \& Peytremann, E. 1975, SAO Special Report 362 (Cambridge: Smithsonian Institution)

Kurucz, R. L., Furenlid, I., \& Brault, J. 1984, Solar flux atlas from 296 to $1300 \mathrm{~nm}$, National Solar Observatory Atlas, Sunspot (New Mexico: National Solar Observatory)

Kusz, J. 1992, A\&AS, 92, 517

Laird, J. B., Carney, B. W., Rupen, M. P., \& Latham, D. W. 1988, AJ, 96, 1908

Lawler, J. E., Bonvallet, G., \& Sneden, C. 2001a, ApJ, 556, 452

Lawler, J. E., Wickliffe, M. E., \& Hartog, A. D. 2001b, ApJ, 563, 1075

Lejeune, T., Cuisinier, F., \& Buser, R. 1998, A\&AS, 130, 65

Lodders, K. 2003, ApJ, 591, 1220

Lucatello, S., Gratton, R., Cohen, J. G., et al. 2003, AJ, 125, 875

Lucatello, S., Tsangarides, S., Gratton, R. G., et al. 2005, ApJ, 625, 825

Lucatello, S., Beers, T. C., Christlieb, N., et al. 2006, ApJ, 652, L37

Maier, R. S., \& Whaling, W. 1977, JQSRT, 18, 501

Marsteller, B., Beers, T. C., Thirupathi, S., et al. 2009, AJ, 138, 533

Martin, G. A., Fuhr, J. R., \& Weise, W. L. 1988, J. Phys. Chem. Ref. D, 17, 3

Martin, W. C., Fuhr, J. R., Kelleher, D. E., et al. 2002, NIST Atomic Database, version 2.0, National Institute of Standards and Technology, Gaithersburg, MD, http://physics.nist.gov/asd

Mashonkina, L., \& Gehren, T. 2001, A\&A, 376, 232

Masseron, T., Johnson, J. A., Plez, B., et al. 2010, A\&A, 509, 93

Matsuoka, K., Nagao, T., Maiolino, R., Marconi, A., \& Taniguchi, Y. 2011, A\&A, 532, L10
McWilliam, A. 1998, AJ, 115, 1640

McWilliam, A., Preston, G. W., Sneden, C., \& Searle, L. 1995, AJ, 109, 2757

Meynet, G., Ekström, S., \& Maeder, A. 2006, A\&A, 447, 623

Meynet, G., Hirschi, R., Ekstrom, S., et al. 2010a, IAUS, 265, 98

Meynet, G., Hirschi, R., Ekstrom, S., et al. 2010b, A\&A, 521, A30

Norris, J. E., Ryan, S. G., \& Beers, T. C. 1997, ApJ, 488, 350

Norris, J. E., Ryan, S. G., \& Beers, T. C. 2001, ApJ, 561, 1034

Norris, J. E., Ryan, S. G., Beers, T. C., Aoki, W., \& Ando, H. 2002, ApJ, 569, L107

Norris, J. E., Christlieb, N., Korn, A. J., et al. 2007, ApJ, 670, 774

Palmeri, P., Quinet, P., Wyart, J. F., \& Biémont, E. 2000, Physica Scripta, 61, 323

Piskunov, N. E., Kupka, F., Ryabchikova, T. A., Weiss, W. W., \& Jeffery, C. S. 1995, A\&AS, 112, 525

Plez, B., \& Cohen, J. G. 2005, A\&A, 434, 1117

Preston, G. W., \& Sneden, C. 2001, AJ, 122, 1545

Prochaska, J. X., Naumov, S. O., Carney, B. W., McWilliam, A., \& Wolfe, A. M. 2000, AJ, 120, 2513

Qian, Y.-Z., \& Wasserburg, G. J. 2001, ApJ, 552, L55

Qian, Y.-Z., \& Wasserburg, G. J. 2003, ApJ, 588, 1099

Roederer, I. U., Frebel, A., Shetrone, M. D., et al. 2008, ApJ, 679, 1549

Rossi, S., Beers, T. C., \& Sneden, C. 1999, ASPC, 165, 264

Rutten, R. J. 1978, Sol. Phys., 56, 237

Ryabchikova, T. A., Piskunov, N. E., Kupka, F., \& Weiss, W. W. 1997, Balt. Astron., 6, 244

Ryan, S. G. 2003, ASP Conf. Ser., 304, 128

Ryan, S. G., \& Lambert, D. L. 1995, AJ, 109, 2068

Ryan, S. G., Aoki, W., Norris, J. E., \& Beers, T. C. 2005, ApJ, 635, 349

Schlegel, D. J., Finkbeiner, D. P., \& Davis, M. 1998, ApJ, 500, 525

Siess, L., Livio, M., \& Lattanzio, J. 2002, ApJ, 570, 329

Sivarani, T., Bonifacio, P., Molaro, P., et al. 2004, A\&A, 413, 1073

Sivarani, T., Beers, T. C., Bonifacio, P., et al. 2006, A\&A, 459, 125

Sneden, C., McWilliam, A., Preston, G. W., et al. 1996, ApJ, 467, 819

Sneden, C., Cowan, J. J., Lawler, J. E., et al. 2003, ApJ, 591, 936

Skrutskie, M. F., Schneider, S. E., Stiening, R., et al. 1997, ASSL, 210, 25

Thévenin, F. 1989, A\&AS, 77, 137

Thompson, I. B., Ivans, I. I., Bisterzo, S., et al. 2008, ApJ, 677, 556

Tomkin, J., Lemke, M., Lambert, D. L., \& Sneden, C. 1992, AJ, 14, 1568

Travaglio, C., Galli, D., Gallino, R., et al. 1999, ApJ, 521, 691

Truran, J. W. 1981, A\&A, 97, 391

Tsangarides, S. A. 2005, PhD. Thesis, The Open University-UK

Turatto, M., Mazzali, P. A., Young, T. R., et al. 1998, ApJ, 498, L129

Umeda, H., \& Nomoto, K. 2003, Nature, 422, 871

Van Eck, S., Goriely, S., Jorissen, A., \& Plez, B. 2003, A\&A, 404, 291

Wanajo, S., Nomoto, K., Iwamoto, N., Ishimaru, Y., \& Beers, T. C. 2006, ApJ, 636,842

Woosley, S. E., \& Weaver, T. A. 1995, ApJS, 101, 181

Yi, S., Demarque, P., Kim, Y.-C., et al. 2001, ApJS, 136, 417

Yi, S. K., Kim, Y.-C., \& Demarque, P. 2003, ApJS, 144, 259

Zampieri, L., Pastorello, A., Turatto, M., et al. 2003, MNRAS, 338, 711 
D. M. Allen et al.: Elemental abundances and classification of CEMP stars

Table 1. Colours and magnitudes of our program stars before dereddening.

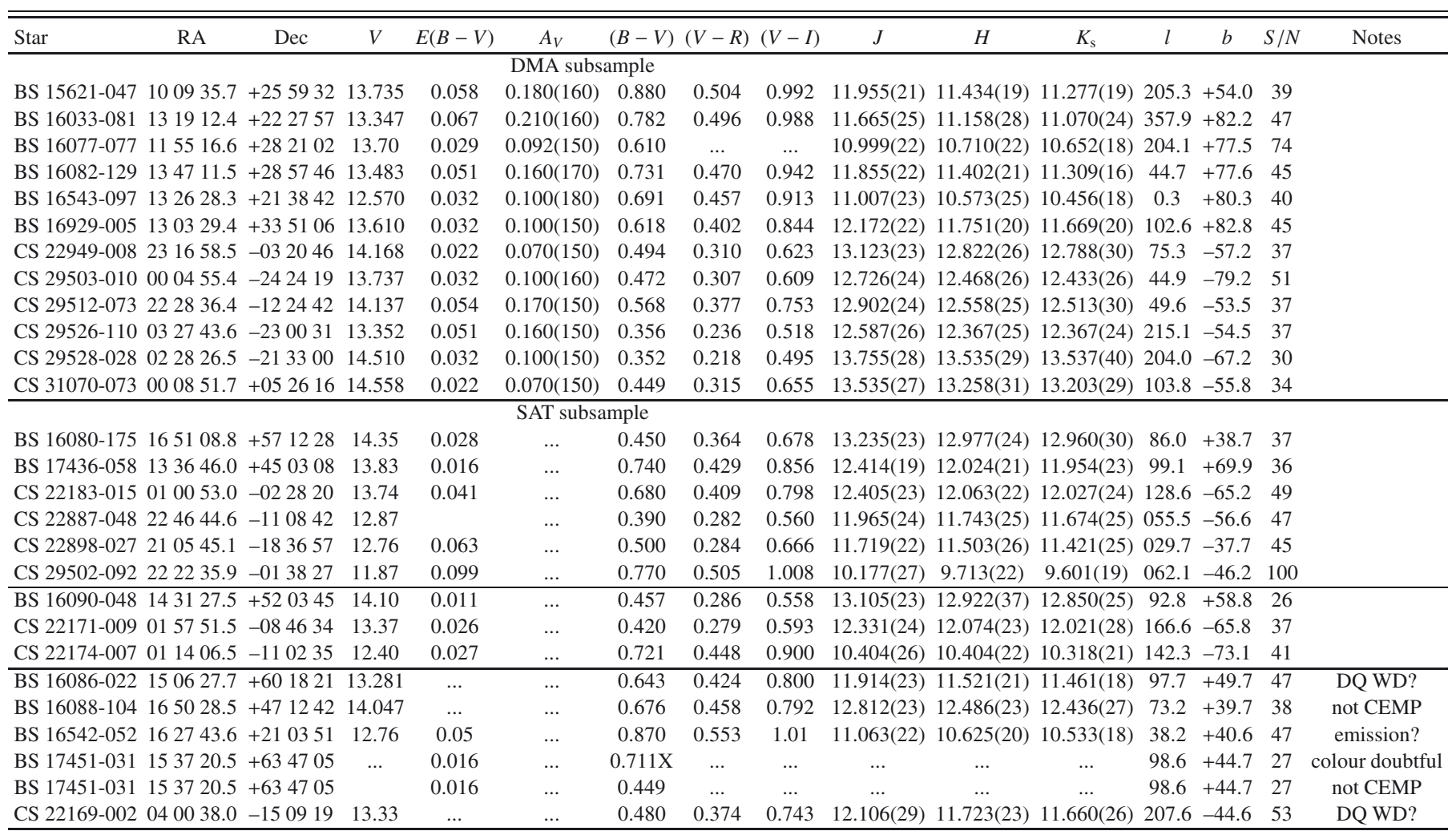

Notes. The last four columns are the Galactic coordinates, the $\mathrm{S} / \mathrm{N}$ of the high-resolution spectra around $\lambda 4500$, and (for some stars) notes. A suffix " $\mathrm{X}$ " indicates that the value was not used. 
A\&A 548, A34 (2012)

Table 3. Temperatures derived from photometric data by using the final metallicity found for each star.

\begin{tabular}{|c|c|c|c|c|c|c|c|}
\hline Star & {$[\mathrm{Fe} / \mathrm{H}]$} & $T_{B V}$ & $T_{V R}$ & $T_{V I}$ & $T_{V K}$ & $T_{J K}$ & $T_{J H}$ \\
\hline \multicolumn{8}{|c|}{ DMA subsample } \\
\hline \multirow{2}{*}{ BS 15621-047 } & -2.29 & 4730 & 4860 & 4870 & 4770 & 4620 & 4740 \\
\hline & -2.35 & 4730 & 4870 & 4860 & 4780 & 4620 & 4740 \\
\hline \multirow{2}{*}{ BS 16033-081 } & -2.20 & 5170 & 5020 & 5020 & 5140 & 5090 & 5040 \\
\hline & -2.07 & 5180 & 5020 & 5010 & 5130 & 5090 & 5060 \\
\hline \multirow[t]{2}{*}{ BS 16077-077 } & -2.05 & $5440 X$ & $\ldots$ & $\ldots$ & $4220 \mathrm{X}$ & 5890 & 5830 \\
\hline & -2.00 & $5450 X$ & $\ldots$ & & $4220 X$ & 5890 & 5830 \\
\hline \multirow[t]{2}{*}{ BS 16082-129 } & -2.65 & 5090 & 4980 & 5010 & 5100 & 5050 & 4970 \\
\hline & -2.59 & 5100 & 4980 & 5010 & 5090 & 5050 & 4970 \\
\hline \multirow[t]{2}{*}{ BS 16543-097 } & -2.48 & 5170 & 5000 & 5030 & 5090 & 4990 & 5040 \\
\hline & -2.36 & 5170 & 5000 & 5020 & 5090 & 4990 & 5050 \\
\hline \multirow[t]{2}{*}{ BS 16929-005 } & -3.15 & 5400 & 5190 & 5350 & 5360 & 5180 & 4990 \\
\hline & -3.02 & 5390 & 5190 & 5340 & 5350 & 5180 & 5020 \\
\hline \multirow[t]{2}{*}{ CS 22949-008 } & -2.45 & 5740 & 5950 & 5920 & 5990 & 5960 & 5750 \\
\hline & -2.61 & 5740 & 5960 & 5920 & 6000 & 5960 & 5750 \\
\hline \multirow[t]{2}{*}{ CS 29503-010 } & -1.69 & 5990 & 5950 & 5840 & 6260 & 6220 & 6050 \\
\hline & -1.70 & 5990 & 5950 & 5840 & 6260 & 6220 & 6050 \\
\hline \multirow[t]{2}{*}{ CS 29512-073 } & -2.06 & 5680 & 5520 & 5460 & 5850 & 5750 & 5560 \\
\hline & -1.88 & 5690 & 5520 & 5460 & 5840 & 5750 & 5580 \\
\hline \multirow[t]{2}{*}{ CS 29526-110 } & -2.19 & 6600 & 6390 & 6470 & 7100 & 6790 & 6320 \\
\hline & -2.29 & 6600 & 6390 & 6480 & 7110 & 6790 & 6300 \\
\hline \multirow[t]{2}{*}{ CS 29528-028 } & -2.12 & 6500 & 6690 & 6790 & 6960 & 6840 & 6350 \\
\hline & -2.17 & 6500 & 6690 & 6790 & 6970 & 6840 & 6350 \\
\hline \multirow[t]{2}{*}{ CS 31070-073 } & -2.55 & 6020 & 5750 & 5800 & 6200 & 5950 & 5820 \\
\hline & -2.64 & 6020 & 5750 & 5810 & 6210 & 5950 & 5800 \\
\hline \multicolumn{8}{|c|}{ SAT subsample } \\
\hline BS $16080-175$ & -1.36 & 5942 & 6329 & 6247 & $\ldots$ & 6328 & 5970 \\
\hline BS 17436-058 & -1.90 & 4986 & 5246 & 5209 & $\ldots$ & 5416 & 5467 \\
\hline CS 22183-015 & -2.85 & 5291 & 5416 & 5468 & $\ldots$ & 5600 & 5588 \\
\hline CS 22887-048 & -1.70 & $\ldots$ & $\ldots$ & $\ldots$ & $\ldots$ & 6508 & 6581 \\
\hline CS 22898-027 & -2.30 & 6039 & 6562 & $\ldots$ & $\ldots$ & 6477 & 6363 \\
\hline CS 29502-092 & -3.05 & 5224 & 5064 & 5068 & $\ldots$ & 4978 & 5060 \\
\hline
\end{tabular}

Notes. For the DMA subsample, the first and second lines show the results for stellar parameters using $[\mathrm{FeI} / \mathrm{H}]$ and $[\mathrm{FeII} / \mathrm{H}]$, respectively. For the SAT subsample only one $[\mathrm{Fe} / \mathrm{H}]$ value is given since ionisation balance was forced in determining $\log g$. A suffix " $\mathrm{X}$ " indicates that the value was not used. 
D. M. Allen et al.: Elemental abundances and classification of CEMP stars

Table 4. Results for the stellar parameters, for the DMA (upper portion) and SAT (lower portion) subsamples.

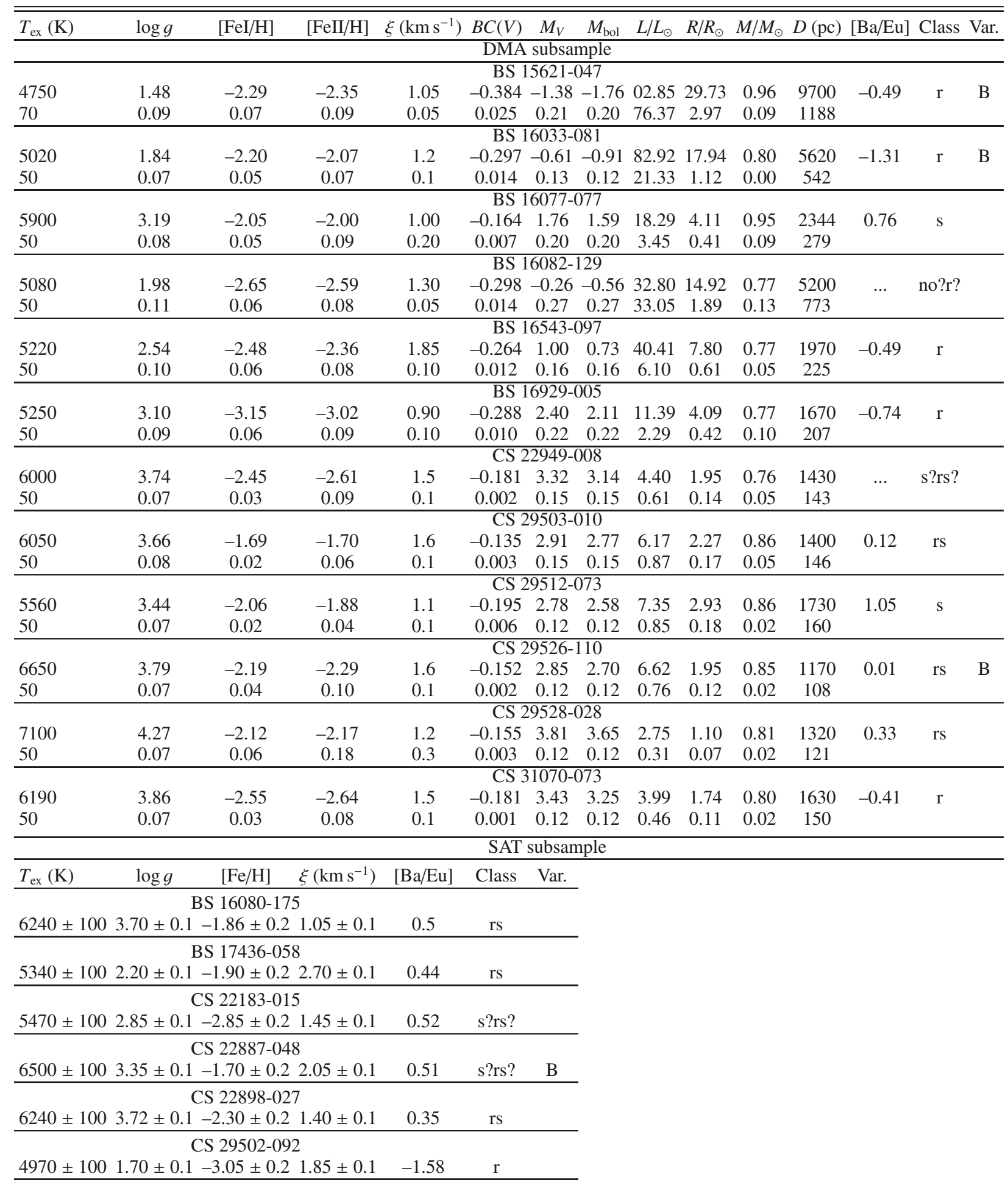

Notes. For the DMA subsample, $T_{\mathrm{ex}}$ is the excitation temperature, $M_{\mathrm{bol}}$ is the bolometric magnitude, $L$ is the luminosity, $R$ is the radii, $M$ the mass, $\pi$ the parallax. Uncertainties are shown in the second line. For $[\mathrm{Fe} / \mathrm{H}]$, the uncertainties are the standard error of the mean abundance, excluding the effects of errors on atmosphere parameters. SAT did not use isochrones, so did not determine values for $B C(V), M_{V}, M_{\mathrm{bol}}, L, R, M$ or $D$. The last column indicates whether the star is binary or not, according to Tsangarides (2005). 
Table 8. Average of abundances for the DMA subsample of CEMP stars, and solar abundances used as reference, as well as their sources.

\begin{tabular}{|c|c|c|c|c|c|c|c|c|c|c|c|c|c|c|}
\hline \multirow[b]{2}{*}{ el } & \multicolumn{2}{|c|}{ BS 15621-047 } & \multicolumn{2}{|c|}{ BS 16033-081 } & \multicolumn{2}{|c|}{ BS 16077-077 } & \multicolumn{2}{|c|}{ BS 16082-129 } & \multicolumn{2}{|c|}{ BS 16543-097 } & \multicolumn{2}{|c|}{ BS 16929-005 } & & \\
\hline & $\log \epsilon(\mathrm{X})$ & {$[\mathrm{X} / \mathrm{Fe}]$} & $\log \epsilon(\mathrm{X})$ & {$[\mathrm{X} / \mathrm{Fe}]$} & $\log \epsilon(\mathrm{X})$ & {$[\mathrm{X} / \mathrm{Fe}]$} & $\log \epsilon(\mathrm{X})$ & {$[\mathrm{X} / \mathrm{Fe}]$} & $\log \epsilon(\mathrm{X})$ & {$[\mathrm{X} / \mathrm{Fe}]$} & $\log \epsilon(\mathrm{X})$ & {$[\mathrm{X} / \mathrm{Fe}]$} & & \\
\hline $\mathrm{C}$ & 7.23 & $1.06(31)$ & 7.22 & $0.77(36)$ & 8.77 & $2.25(18)$ & 7.13 & $1.20(30)$ & 7.31 & $1.15(33)$ & 7.00 & $1.50(23)$ & & \\
\hline $\mathrm{Na}$ & 5.33 & $1.35(36)$ & 4.83 & $0.57(29)$ & $\ldots$ & $\ldots$ & $\ldots$ & $\ldots$ & $\ldots$ & $\ldots$ & 3.83 & $0.52(29)$ & & \\
\hline $\mathrm{Mg}$ & 6.08 & $0.85(25)$ & 5.58 & $0.07(32)$ & 6.08 & $0.50(19)$ & $\ldots$ & $\ldots$ & 5.78 & $0.56(20)$ & 5.28 & $0.72(20)$ & & \\
\hline $\mathrm{Sc}$ & 1.37 & $0.55(37)$ & 1.49 & $0.39(29)$ & 1.67 & $0.50(16)$ & $\ldots$ & $\ldots$ & $\ldots$ & $\ldots$ & $\ldots$ & $\ldots$ & & \\
\hline $\mathrm{Ti}$ & 3.02 & $0.35(26)$ & 3.41 & $0.46(22)$ & 3.76 & $0.74(14)$ & 3.02 & $0.59(26)$ & 3.12 & $0.46(18)$ & 2.72 & $0.72(22)$ & & \\
\hline $\mathrm{Cr}$ & 3.67 & $0.35(14)$ & 4.12 & $0.52(21)$ & 4.07 & $0.40(13)$ & 3.67 & $0.59(20)$ & 3.17 & $-0.14(17)$ & 3.17 & $0.52(18)$ & & \\
\hline $\mathrm{Cu}$ & $\ldots$ & $\ldots$ & $\ldots$ & $\ldots$ & $\ldots$ & $\ldots$ & $\ldots$ & $\ldots$ & $\ldots$ & $\ldots$ & $\ldots$ & $\ldots$ & & \\
\hline $\mathrm{Zn}$ & 3.86 & $1.61(48)$ & 2.84 & $0.31(58)$ & 3.18 & $0.58(30)$ & 2.60 & $0.59(72)$ & 2.60 & $0.36(48)$ & $\ldots$ & $\ldots$ & & \\
\hline Sr I & 1.87 & $1.25(37)$ & 0.97 & $0.07(29)$ & $\ldots$ & $\ldots$ & $\ldots$ & $\ldots$ & 1.47 & $0.86(22)$ & $\ldots$ & $\ldots$ & & \\
\hline Sr II & 0.86 & $0.24(20)$ & 0.77 & $-0.13(24)$ & 0.91 & $-0.06(16)$ & -0.03 & $-0.41(30)$ & 0.79 & $0.18(20)$ & 0.47 & $0.52(23)$ & & \\
\hline Y & 0.40 & $0.51(15)$ & -0.02 & $-0.19(19)$ & 0.12 & $-0.12(13)$ & -0.26 & $0.09(26)$ & 0.36 & $0.48(15)$ & 0.24 & $1.02(18)$ & & \\
\hline $\mathrm{Zr}$ & 1.41 & $1.16(69)$ & 0.60 & $0.07(19)$ & 0.58 & $-0.02(30)$ & 0.60 & $0.59(70)$ & 1.10 & $0.86(38)$ & 1.10 & $1.52(50)$ & & \\
\hline $\mathrm{Ba}$ & 0.13 & $0.35(21)$ & -0.87 & $-0.93(18)$ & 0.88 & $0.75(13)$ & -0.87 & $-0.41(21)$ & 0.13 & $0.36(16)$ & -0.62 & $0.27(18)$ & & \\
\hline $\mathrm{La}$ & -0.72 & $0.50(34)$ & -0.83 & $0.11(35)$ & -0.29 & $0.58(21)$ & $\ldots$ & $\ldots$ & -0.59 & $0.64(27)$ & -0.53 & $1.36(38)$ & & \\
\hline $\mathrm{Ce}$ & 0.62 & $1.27(37)$ & -0.15 & $0.22(29)$ & 0.30 & $0.60(16)$ & -0.22 & $0.67(37)$ & -0.10 & $0.56(22)$ & $\ldots$ & $\ldots$ & & \\
\hline $\mathrm{Nd}$ & 0.32 & $1.22(16)$ & -0.31 & $0.31(15)$ & 0.05 & $0.60(12)$ & -0.50 & $0.64(16)$ & 0.20 & $1.11(14)$ & 0.00 & $1.57(15)$ & & \\
\hline $\mathrm{Sm}$ & 0.19 & $1.53(30)$ & $\ldots$ & $\ldots$ & $\ldots$ & $\ldots$ & $\ldots$ & $\ldots$ & $\ldots$ & $\ldots$ & $\ldots$ & $\ldots$ & & \\
\hline $\mathrm{Eu}$ & -0.99 & $0.84(28)$ & -1.17 & $0.38(25)$ & -1.49 & $-0.01(20)$ & $\ldots$ & $\ldots$ & -0.99 & $0.85(22)$ & -1.49 & $1.01(25)$ & & \\
\hline $\mathrm{Gd}$ & -0.06 & $1.17(29)$ & -0.38 & $0.57(31)$ & -0.88 & $0.00(21)$ & $\ldots$ & $\ldots$ & -0.88 & $0.36(28)$ & $\ldots$ & $\ldots$ & & \\
\hline \multirow[t]{2}{*}{ Dy } & 0.25 & $1.40(36)$ & -0.36 & $0.51(29)$ & $\ldots$ & $\ldots$ & $\ldots$ & $\ldots$ & $\ldots$ & $\ldots$ & $\ldots$ & $\ldots$ & & \\
\hline & \multicolumn{2}{|c|}{ CS 22949-008 } & \multicolumn{2}{|c|}{ CS 29503-010 } & \multicolumn{2}{|c|}{ CS 29512-073 } & \multicolumn{2}{|c|}{ CS 29526-110 } & \multicolumn{2}{|c|}{ CS 29528-028 } & \multicolumn{2}{|c|}{ CS 31070-073 } & \multicolumn{2}{|c|}{ SUN } \\
\hline el & $\log \epsilon(\mathrm{X})$ & {$[\mathrm{X} / \mathrm{Fe}]$} & $\log \epsilon(\mathrm{X})$ & {$[\mathrm{X} / \mathrm{Fe}]$} & $\log \epsilon(\mathrm{X})$ & {$[\mathrm{X} / \mathrm{Fe}]$} & $\log \epsilon(\mathrm{X})$ & {$[\mathrm{X} / \mathrm{Fe}]$} & $\log \epsilon(\mathrm{X})$ & {$[\mathrm{X} / \mathrm{Fe}]$} & $\log \epsilon(\mathrm{X})$ & {$[\mathrm{X} / \mathrm{Fe}]$} & $\log \epsilon(\mathrm{X})$ & Ref. \\
\hline $\mathrm{C}$ & 7.91 & $2.00(25)$ & 8.47 & $1.65(20)$ & 8.04 & $1.40(25)$ & 8.61 & $2.38(20)$ & 9.11 & $2.76(30)$ & 7.22 & $1.34(22)$ & $8.52(6)$ & 1 \\
\hline $\mathrm{Na}$ & $\ldots$ & $\ldots$ & 5.44 & $0.81(22)$ & $\ldots$ & $\ldots$ & $\ldots$ & $\ldots$ & $\ldots$ & $\ldots$ & $\ldots$ & $\ldots$ & $6.33(3)$ & 1 \\
\hline $\mathrm{Mg}$ & $\ldots$ & $\ldots$ & 6.08 & $0.20(20)$ & 6.08 & $0.38(20)$ & $\ldots$ & $\ldots$ & $\ldots$ & $\ldots$ & 5.58 & $0.64(20)$ & $7.58(5)$ & 1 \\
\hline $\mathrm{Sc}$ & $\ldots$ & $\ldots$ & 2.27 & $0.80(22)$ & 1.67 & $0.38(37)$ & $\ldots$ & $\ldots$ & $\ldots$ & $\ldots$ & $\ldots$ & $\ldots$ & $3.17(0)$ & 1 \\
\hline $\mathrm{Ti}$ & 3.02 & $0.61(22)$ & 4.05 & $0.73(18)$ & 3.52 & $0.38(26)$ & $\ldots$ & $\ldots$ & $\ldots$ & $\ldots$ & $\ldots$ & $\ldots$ & $5.02(6)$ & 1 \\
\hline $\mathrm{Cr}$ & 3.17 & $0.11(18)$ & 4.17 & $0.20(15)$ & $\ldots$ & $\ldots$ & $\ldots$ & $\ldots$ & $\ldots$ & $\ldots$ & $\ldots$ & $\ldots$ & $5.37(3)$ & 1 \\
\hline $\mathrm{Cu}$ & $\ldots$ & $\ldots$ & 2.61 & $0.10(22)$ & $\ldots$ & $\ldots$ & $\ldots$ & $\ldots$ & $\ldots$ & $\ldots$ & $\ldots$ & $\ldots$ & $4.21(4)$ & 1 \\
\hline $\mathrm{Zn}$ & $\ldots$ & $\ldots$ & 3.54 & $0.64(30)$ & 3.10 & $0.38(41)$ & $\ldots$ & $\ldots$ & $\ldots$ & $\ldots$ & $\ldots$ & $\ldots$ & $4.60(8)$ & 1 \\
\hline Sr I & $\ldots$ & $\ldots$ & 2.47 & $1.20(22)$ & 1.97 & $0.88(37)$ & $\ldots$ & $\ldots$ & 2.97 & $2.17(29)$ & 2.07 & $1.74(29)$ & 2.97(7) & 1 \\
\hline $\mathrm{Sr}$ II & 0.19 & $-0.17(25)$ & 2.32 & $1.05(18)$ & 1.71 & $0.62(20)$ & 0.97 & $0.29(19)$ & 2.07 & $1.27(27)$ & 0.29 & $-0.04(21)$ & 2.97(7) & 1 \\
\hline Y & 0.88 & $1.25(18)$ & 1.63 & $1.09(12)$ & 0.96 & $0.60(16)$ & 1.24 & $1.29(20)$ & 2.06 & $1.99(26)$ & 1.56 & $1.96(20)$ & $2.24(3)$ & 1 \\
\hline $\mathrm{Zr}$ & 1.60 & $1.61(60)$ & 2.16 & $1.26(35)$ & 1.31 & $0.59(50)$ & 2.10 & $1.79(50)$ & 2.60 & $2.17(60)$ & 1.92 & $1.96(60)$ & $2.60(2)$ & 1 \\
\hline $\mathrm{Ba}$ & 0.50 & $0.98(18)$ & 2.24 & $1.81(16)$ & 1.67 & $1.42(21)$ & 2.13 & $2.29(16)$ & 2.45 & $2.49(18)$ & 1.91 & $2.42(18)$ & $2.13(5)$ & 1 \\
\hline $\mathrm{La}$ & $\ldots$ & $\ldots$ & 1.59 & $2.16(20)$ & 0.67 & $1.42(30)$ & 1.41 & $2.57(30)$ & 1.17 & $2.21(45)$ & 1.09 & $2.60(24)$ & $1.13(3)$ & 2 \\
\hline $\mathrm{Ce}$ & 0.58 & $1.49(29)$ & 2.05 & $2.05(22)$ & 1.45 & $1.63(37)$ & 1.70 & $2.29(22)$ & 2.00 & $2.47(29)$ & 1.71 & $2.65(29)$ & $1.70(4)$ & 3 \\
\hline $\mathrm{Nd}$ & 0.82 & $1.98(15)$ & 2.06 & $2.31(14)$ & 1.14 & $1.57(16)$ & 1.35 & $2.19(14)$ & 1.82 & $2.54(15)$ & 1.33 & $2.52(15)$ & $1.45(1)$ & 4 \\
\hline $\mathrm{Sm}$ & -0.99 & $0.61(30)$ & 1.65 & $2.34(15)$ & 1.01 & $1.88(37)$ & $\ldots$ & $\ldots$ & $\ldots$ & $\ldots$ & 0.71 & $2.34(30)$ & $1.01(6)$ & 5 \\
\hline $\mathrm{Eu}$ & $\ldots$ & $\ldots$ & 0.51 & $1.69(22)$ & -0.99 & $0.37(28)$ & 0.51 & $2.28(22)$ & 0.51 & $2.16(25)$ & 0.71 & $2.83(25)$ & $0.52(1)$ & 6 \\
\hline $\mathrm{Gd}$ & $\ldots$ & $\ldots$ & $\ldots$ & $\ldots$ & 0.62 & $1.38(39)$ & $\ldots$ & $\ldots$ & $\ldots$ & $\ldots$ & $\ldots$ & $\ldots$ & $1.12(4)$ & 1 \\
\hline Dy & $\ldots$ & $\ldots$ & 0.55 & $1.05(22)$ & 0.64 & $1.32(36)$ & $\ldots$ & $\ldots$ & $\ldots$ & $\ldots$ & $\ldots$ & $\ldots$ & $1.20(6)$ & 7 \\
\hline
\end{tabular}

Notes. Numbers in parenthesis are the errors in the last decimals.

References. (1) Grevesse \& Sauval (1998); (2) Lawler et al. (2001a); (3) Palmeri et al. (2000); (4) Hartog et al. (2003); (5) Biémont et al. (1989); (6) Lawler et al. (2001b); (7) Biémont \& Lowe (1993). 
D. M. Allen et al.: Elemental abundances and classification of CEMP stars

Table 9. Average of abundances for the SAT subsample of CEMP stars.

\begin{tabular}{|c|c|c|c|c|c|c|c|c|c|c|}
\hline \multirow[b]{2}{*}{ el } & \multicolumn{2}{|c|}{ BS 16080-175 } & \multicolumn{2}{|c|}{ BS 17436-058 } & \multicolumn{2}{|c|}{ CS 22183-015 } & \multicolumn{2}{|c|}{ CS 22887-048 } & \multicolumn{2}{|c|}{ CS 22898-027 } \\
\hline & $\log \epsilon(\mathrm{X})$ & {$[\mathrm{X} / \mathrm{Fe}]$} & $\log \epsilon(\mathrm{X})$ & {$[\mathrm{X} / \mathrm{Fe}]$} & $\log \epsilon(\mathrm{X})$ & {$[\mathrm{X} / \mathrm{Fe}]$} & $\log \epsilon(\mathrm{X})$ & {$[\mathrm{X} / \mathrm{Fe}]$} & $\log \epsilon(\mathrm{X})$ & {$[\mathrm{X} / \mathrm{Fe}]$} \\
\hline $\mathrm{C}$ & -0.01 & 1.75 & -0.28 & 1.50 & -0.51 & 2.34 & 0.14 & 1.84 & 0.04 & 2.34 \\
\hline $\mathrm{N}$ & $<-1.06$ & $<0.80$ & -0.28 & 1.25 & -1.06 & 1.79 & $<-0.41$ & $<1.29$ & -1.06 & 1.24 \\
\hline TiI & -1.22 & 0.64 & -1.59 & 0.19 & -2.38 & 0.47 & $\ldots$ & $\ldots$ & $\ldots$ & $\ldots$ \\
\hline TilI & -1.56 & 0.30 & -1.32 & 0.46 & -2.63 & 0.22 & -1.22 & 0.48 & -1.98 & 0.32 \\
\hline $\mathrm{Zn}$ & -1.66 & 0.20 & -1.77 & 0.01 & $<-2.51$ & $<0.34$ & $<-0.93$ & $<0.77$ & -1.76 & 0.54 \\
\hline $\mathrm{Sr}$ & -0.82 & 1.04 & -0.83 & 0.95 & -2.31 & 0.54 & -0.70 & 1.00 & -1.71 & 0.59 \\
\hline $\mathrm{Y}$ & -0.79 & 1.07 & -1.05 & 0.73 & -2.31 & 0.54 & -0.71 & 0.99 & -1.70 & 0.60 \\
\hline $\mathrm{Zr}$ & -0.57 & 1.29 & -0.85 & 0.93 & -2.11 & 0.74 & -0.47 & 1.23 & -1.02 & 1.28 \\
\hline $\mathrm{Ba}$ & -0.31 & 1.55 & -0.17 & 1.61 & -0.96 & 1.89 & 0.30 & 2.00 & -0.04 & 2.26 \\
\hline $\mathrm{La}$ & -0.21 & 1.65 & -0.29 & 1.49 & -1.32 & 1.53 & 0.03 & 1.73 & -0.11 & 2.19 \\
\hline $\mathrm{Eu}$ & -0.81 & 1.05 & -0.61 & 1.17 & -1.48 & 1.37 & -0.21 & 1.49 & -0.39 & 1.91 \\
\hline \multirow[t]{2}{*}{$\mathrm{Pb}$} & 0.74 & 2.60 & 0.48 & 2.26 & 0.15 & 3.00 & 1.70 & 3.40 & 0.59 & 2.89 \\
\hline & \multicolumn{2}{|c|}{ CS 29502-092 } & & & \multicolumn{2}{|c|}{ BS 16090-048 } & \multicolumn{2}{|c|}{ CS 22171-009 } & \multicolumn{2}{|c|}{ CS 22174-007 } \\
\hline el & $\log \epsilon(\mathrm{X})$ & {$[\mathrm{X} / \mathrm{Fe}]$} & & & $\overline{\log \epsilon(\mathrm{X})}$ & {$[\mathrm{X} / \mathrm{Fe}]$} & $\log \epsilon(\mathrm{X})$ & {$[\mathrm{X} / \mathrm{Fe}]$} & $\log \epsilon(\mathrm{X})$ & {$[\mathrm{X} / \mathrm{Fe}]$} \\
\hline $\mathrm{C}$ & -1.86 & 1.18 & & & -0.70 & 0.69 & $<-1.53$ & $<1.03$ & -2.46 & 0.25 \\
\hline $\mathrm{N}$ & -1.76 & 1.28 & & & -0.55 & 0.84 & $<-0.03$ & $<2.53$ & $<-2.11$ & $<0.60$ \\
\hline TiI & -2.98 & 0.06 & & & -1.14 & 0.25 & $\ldots$ & $\ldots$ & -2.43 & 0.28 \\
\hline TiII & -2.95 & 0.09 & & & -0.93 & 0.46 & -2.27 & 0.29 & -2.33 & 0.38 \\
\hline $\mathrm{Zn}$ & -2.86 & 0.18 & & & $\ldots$ & $\ldots$ & $<-2.02$ & $<0.54$ & -2.56 & 0.15 \\
\hline $\mathrm{Sr}$ & -3.54 & -0.50 & & & $\ldots$ & $\ldots$ & -2.60 & 0.04 & -2.93 & -0.22 \\
\hline $\mathrm{Y}$ & -3.54 & -0.50 & & & $\ldots$ & $\ldots$ & $<-2.29$ & $<0.27$ & -3.02 & -0.31 \\
\hline $\mathrm{Zr}$ & $<-3.41$ & $<-0.37$ & & & $\ldots$ & $\ldots$ & $<-1.76$ & $<0.80$ & -2.67 & 0.04 \\
\hline $\mathrm{Ba}$ & -4.41 & -1.37 & & & $\ldots$ & $\ldots$ & -2.83 & -0.27 & -2.75 & -0.04 \\
\hline $\mathrm{La}$ & $<-3.10$ & $<0.06$ & & & $\ldots$ & $\ldots$ & $<-1.58$ & $<0.98$ & -2.75 & -0.04 \\
\hline $\mathrm{Eu}$ & $<-2.83$ & $<0.21$ & & & $\ldots$ & $\ldots$ & $<-0.73$ & $<1.83$ & -2.41 & 0.30 \\
\hline $\mathrm{Pb}$ & $<-1.51$ & $<1.53$ & & & $\ldots$ & $\ldots$ & $<-0.49$ & $<2.07$ & $<-1.43$ & $<1.28$ \\
\hline
\end{tabular}

Table 10. Comparison between results from this work and from the literature.

\begin{tabular}{|c|c|c|c|c|c|c|c|c|c|c|c|}
\hline Star & $T_{\mathrm{eff}}(\mathrm{K})$ & $\log g$ & {$[\mathrm{FeI} / \mathrm{H}]$} & {$[\mathrm{FeII} / \mathrm{H}]$} & $\xi\left(\mathrm{km} \mathrm{s}^{-1}\right)$ & {$[\mathrm{C} / \mathrm{Fe}]$} & {$[\mathrm{Ba} / \mathrm{Fe}]$} & {$[\mathrm{Eu} / \mathrm{Fe}]$} & {$[\mathrm{Ba} / \mathrm{Eu}]$} & class & Ref. \\
\hline \multirow[t]{2}{*}{ BS 16082-129 } & 4900 & 1.8 & -2.86 & . & 1.6 & 0.29 & -0.97 & $\ldots$ & $\ldots$ & & 1 \\
\hline & 5080 & 1.98 & -2.65 & -2.59 & 1.30 & 1.20 & -0.87 & $\ldots$ & $\ldots$ & & DMA \\
\hline \multirow[t]{3}{*}{ BS 16929-005 } & 5270 & 2.7 & -3.09 & $\ldots$ & 1.3 & 0.92 & -0.59 & $\ldots$ & $\ldots$ & & 1 \\
\hline & 5250 & 2.8 & -3.2 & $\ldots$ & 2.3 & 1.08 & -0.48 & 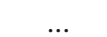 & $\ldots$ & & 2 \\
\hline & 5250 & 3.10 & -3.15 & -3.02 & 0.90 & 1.50 & 0.27 & 1.01 & -0.74 & $\mathrm{r}$ & DMA \\
\hline \multirow[t]{2}{*}{ CS 29503-010 } & 6500 & 4.5 & -1.2 & $\ldots$ & 1.9 & 1.07 & 1.50 & $\ldots$ & $\ldots$ & & 2 \\
\hline & 6050 & 3.66 & -1.69 & -1.70 & 1.6 & 1.65 & 1.81 & 1.69 & 0.12 & rs & DMA \\
\hline \multirow[t]{3}{*}{ CS 29526-110 } & 6500 & 3.2 & -2.38 & $\ldots$ & 1.6 & 2.20 & 2.11 & 1.73 & 0.38 & rs & 3,8 \\
\hline & 6800 & 4.1 & -2.1 & $\ldots$ & 2.1 & 2.08 & 2.39 & $\ldots$ & $\ldots$ & & 4 \\
\hline & 6650 & 3.79 & -2.19 & -2.29 & 1.6 & 2.38 & 2.29 & 2.28 & 0.01 & rs & DMA \\
\hline \multirow[t]{2}{*}{ CS 29528-028 } & 6800 & 4.0 & -2.9 & $\ldots$ & 1.9 & 2.77 & 3.27 & $\ldots$ & $\ldots$ & & 2 \\
\hline & 7100 & 4.27 & -2.12 & -2.17 & 1.2 & 2.76 & 2.49 & 2.16 & 0.33 & rs & DMA \\
\hline \multirow[t]{2}{*}{ CS 22183-015 } & 5200 & 2.0 & -3.12 & $\ldots$ & 1.5 & $\ldots$ & 2.09 & 1.39 & 0.70 & $\mathrm{~s}$ & 5 \\
\hline & 5470 & 2.85 & -2.85 & $\ldots$ & 1.45 & 2.34 & 1.89 & 1.37 & 0.52 & rs & SAT \\
\hline \multirow[t]{4}{*}{ CS 22898-027 } & 6250 & 3.7 & -2.26 & $\ldots$ & 1.5 & 2.2 & 2.23 & 1.88 & 0.35 & rs & 3,8 \\
\hline & 6300 & 4.0 & -2.0 & $\ldots$ & 2.0 & 1.95 & 2.27 & 1.94 & 0.33 & rs & 6 \\
\hline & 6000 & 3.6 & -2.36 & $\ldots$ & 1.42 & 1.90 & 2.67 & 2.04 & 0.58 & $\mathrm{~s}$ & 9 \\
\hline & 6240 & 3.72 & -2.30 & $\ldots$ & 1.40 & 2.34 & 2.26 & 1.91 & 0.35 & rs & SAT \\
\hline \multirow[t]{2}{*}{ CS 29502-092 } & 5000 & 2.1 & -2.76 & $\ldots$ & 1.8 & 1.0 & -0.82 & $>0.4$ & -1.22 & no & 7 \\
\hline & 4970 & 1.70 & -3.05 & $\ldots$ & 1.85 & 1.18 & -1.37 & $<0.21$ & $>-1.58$ & no & SAT \\
\hline
\end{tabular}

References. 1 - Honda et al. (2004); 2 - Aoki et al. (2007); 3 - Aoki et al. (2002d); 4 - Aoki et al. (2008); 5 - Johnson \& Bolte (2002); 6 - Preston \& Sneden (2001); 7 - Aoki et al. (2002a); 8 - Aoki et al. (2002c); 9 - McWilliam et al. (1995). 
Table A.1. Diference between the output value of the synthesis program $\left(\log A_{\mathrm{p}}\right)$ and the output value with $1 \sigma$ of diference in temperature $\left(\Delta_{\mathrm{T}}\right), \log g\left(\Delta_{\mathrm{lg}}\right)$, metallicity $\left(\Delta_{\text {feh }}\right)$, velocity of microturbulent $\left(\Delta_{\xi}\right)$, observational $\left(\Delta_{\mathrm{Obs}}\right)$, and macroturbulence $\Delta_{m u}$.

\begin{tabular}{|c|c|c|c|c|c|c|}
\hline \multicolumn{7}{|c|}{ DMA subsample } \\
\hline Species & $\Delta_{\mathrm{T}}$ & $\Delta_{\mathrm{lg}}$ & $\Delta_{\text {feh }}$ & $\Delta_{\xi}$ & $\Delta_{\text {Obs }}$ & \\
\hline $\mathrm{C}$ & 0.03 & 0.01 & 0.01 & 0.01 & 0.20 & \\
\hline $\mathrm{Na}$ & 0.02 & 0.01 & 0.01 & 0.01 & 0.30 & \\
\hline $\mathrm{Mg}$ & 0.01 & 0.01 & 0.01 & 0.01 & 0.09 & \\
\hline $\mathrm{Sc}$ & 0.01 & 0.02 & 0.02 & 0.01 & 0.40 & \\
\hline $\mathrm{Ti}$ & 0.02 & 0.01 & 0.02 & 0.01 & 0.12 & \\
\hline $\mathrm{Cr}$ & 0.03 & 0.01 & 0.01 & 0.01 & 0.08 & \\
\hline $\mathrm{Cu}$ & 0.02 & 0.01 & 0.01 & 0.01 & 0.40 & \\
\hline $\mathrm{Zn}$ & 0.01 & 0.01 & 0.01 & 0.01 & 0.30 & \\
\hline $\mathrm{Sr}$ & 0.01 & 0.01 & 0.01 & 0.01 & 0.15 & \\
\hline $\mathrm{Y}$ & 0.01 & 0.04 & 0.01 & 0.01 & 0.14 & \\
\hline $\mathrm{Zr}$ & 0.03 & 0.01 & 0.01 & 0.01 & 0.40 & \\
\hline $\mathrm{Ba}$ & 0.02 & 0.03 & 0.01 & 0.02 & 0.10 & \\
\hline $\mathrm{La}$ & 0.01 & 0.03 & 0.01 & 0.01 & 0.25 & \\
\hline $\mathrm{Ce}$ & 0.00 & 0.02 & 0.01 & 0.01 & 0.60 & \\
\hline $\mathrm{Nd}$ & 0.02 & 0.03 & 0.01 & 0.01 & 0.08 & \\
\hline $\mathrm{Sm}$ & 0.01 & 0.02 & 0.01 & 0.01 & 0.70 & \\
\hline Eu & 0.02 & 0.02 & 0.01 & 0.01 & 0.15 & \\
\hline $\mathrm{Gd}$ & 0.10 & 0.03 & 0.01 & 0.01 & 0.50 & \\
\hline Dy & 0.01 & 0.01 & 0.01 & 0.01 & 0.80 & \\
\hline \multicolumn{7}{|c|}{ SAT subsample } \\
\hline Species & $\Delta_{\mathrm{T}}$ & $\Delta_{\mathrm{lg}}$ & $\Delta_{\text {feh }}$ & $\Delta_{\xi}$ & $\Delta_{\mu}$ & $\sigma$ \\
\hline $\mathrm{C}$ & 0.20 & -0.05 & -0.07 & 0.05 & 0.05 & 0.21 \\
\hline $\mathrm{N}$ & 0.10 & 0.05 & 0.05 & 0.05 & 0.05 & 0.13 \\
\hline TiI & 0.11 & 0.04 & 0.05 & 0.01 & 0.00 & 0.10 \\
\hline TilI & 0.11 & 0.07 & -0.04 & 0.02 & 0.00 & 0.09 \\
\hline $\mathrm{Zn}$ & 0.10 & 0.05 & 0.05 & 0.05 & 0.05 & 0.18 \\
\hline $\mathrm{Sr}$ & 0.20 & 0.10 & 0.10 & -0.09 & 0.05 & 0.24 \\
\hline Y & 0.07 & 0.03 & 0.10 & -0.05 & 0.03 & 0.10 \\
\hline $\mathrm{Zr}$ & 0.13 & 0.04 & 0.03 & -0.02 & 0.02 & 0.13 \\
\hline $\mathrm{Ba}$ & 0.13 & 0.02 & 0.03 & 0.05 & 0.05 & 0.14 \\
\hline $\mathrm{La}$ & 0.07 & 0.04 & 0.02 & -0.06 & 0.01 & 0.08 \\
\hline $\mathrm{Eu}$ & 0.09 & 0.04 & 0.02 & -0.06 & 0.05 & 0.09 \\
\hline $\mathrm{Pb}$ & 0.10 & -0.05 & -0.02 & -0.05 & 0.03 & 0.15 \\
\hline
\end{tabular}

Notes. The last column of SAT subsample is the typical uncertainties for each element. 


\section{Appendix B: Data from the literature}

Table B.1. Abundances $[\mathrm{X} / \mathrm{Fe}]$ of light elements for CEMP stars.

\begin{tabular}{|c|c|c|c|c|c|c|c|c|c|c|c|c|c|c|c|c|c|c|c|c|}
\hline Star & $\begin{array}{c}T_{\text {eff }} \\
\mathrm{K}\end{array}$ & $\log g$ & {$[\mathrm{Fe} / \mathrm{H}]$} & $\begin{array}{c}\xi \\
\mathrm{km} \mathrm{s}^{-1}\end{array}$ & $\mathrm{~A}(\mathrm{Li})$ & $\mathrm{C}$ & $\mathrm{N}$ & $\mathrm{O}$ & $\mathrm{Na}$ & $\mathrm{Mg}$ & $\mathrm{Al}$ & $\mathrm{Si}$ & S & $\mathrm{K}$ & $\mathrm{Ca}$ & BM & EM & $\mathrm{BE}$ & Cls. & Ref. \\
\hline BS 16929-005 & 5270 & 2.7 & $\begin{array}{l}-3.09 \\
\end{array}$ & 1.3 & $\ldots$ & 0.92 & & $\ldots$ & $\ldots$ & 0.38 & -0.85 & 0.38 & $\ldots$ & $\ldots$ & 0.46 & & & & & 22 \\
\hline BS 16929-005 & 5250 & 2.8 & 3.17 & 2.3 & 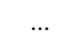 & 1.08 & $<2.39$ & 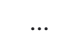 & -0.06 & 0.49 & & & $\ldots .$. & $\ldots$ & 0.13 & & & & & 37 \\
\hline 16929-005 & 5250 & 2.8 & -3.17 & 2.3 & $\ldots$ & 1.08 & $<2.39$ & $\ldots$ & -0.06 & 0.49 & -0.85 & 0.38 & $\ldots$ & $\ldots$ & 0.13 & $\ldots$ & $\ldots$ & $\ldots$ & no & adopted \\
\hline $17435-532$ & 5200 & 2.15 & -2.2 & 2.0 & 2.06 & 0.68 & $\ldots$ & 1.06 & 0.69 & 0.42 & $\ldots$ & 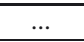 & $\ldots$ & 0.44 & 0.43 & 0.44 & 0.06 & 0.38 & rs & 43 \\
\hline 22166-016 & 5250 & 2.0 & -2.40 & 2.2 & 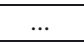 & 1.02 & $\ldots$ & $\ldots$ & 0.37 & 0.68 & $\ldots$ & 0.22 & $\ldots$ & $\ldots$ & .50 & -1.05 & $\ldots$ & $\ldots$ & no & 7 \\
\hline $522877-001$ & 5100 & 2.2 & 2.72 & 2.0 & $<1.2$ & 1.0 & 0.0 & $\ldots$ & -0.24 & 0.29 & -0.72 & & $\ldots$ & $\ldots$ & 0.42 & & & & & 10 \\
\hline S 22877-001 & 5000 & 1.5 & 2.82 & 2.3 & $\ldots$ & 1.80 & $\ldots$ & $\ldots$ & -0.47 & 0.14 & 0.14 & 0.08 & $\ldots$ & $\ldots$ & 0.31 & & & & & 7 \\
\hline CS 22877-001 & 5100 & 2.2 & -2.72 & 2.0 & $<1.2$ & 1.0 & 0.0 & $\ldots$ & -0.24 & 0.29 & -0.72 & $\ldots$ & $\ldots$ & $\ldots$ & 0.42 & -0.78 & 0.31 & -1.09 & no & adopted \\
\hline S 22880-074 & 6050 & 4.0 & -1.76 & 1.9 & $\ldots$ & 1.51 & 0.2 & $\ldots$ & -0.17 & 0.06 & $\ldots$ & $\ldots$ & $\ldots$ & $\ldots$ & 0.2 & & & & & 8 \\
\hline CS 22880-074 & 5850 & 3.8 & -1.93 & 1.4 & $\ldots$ & 1.3 & -0.1 & $\ldots$ & $\ldots$ & 0.46 & -0.66 & $\ldots$ & $\ldots$ & $\ldots$ & 0.67 & & & & & 12 \\
\hline CS 22880-074 & 5950 & 3.9 & -1.85 & 1.7 & $\ldots$ & 1.41 & 0.05 & $\ldots$ & -0.17 & 0.26 & -0.66 & $\ldots$ & $\ldots$ & $\ldots$ & 0.44 & 1.07 & 0.27 & 0.8 & $\mathrm{~s}$ & adopted \\
\hline S 22881-036 & 6200 & 4.0 & -2.06 & 2.2 & $\ldots$ & 1.96 & 1.0 & $\ldots$ & 0.16 & 0.40 & $\ldots$ & $\ldots$ & $\ldots$ & $\ldots$ & 0.62 & 1.53 & 0.6 & 0.93 & $\mathrm{~s}$ & 8 \\
\hline S 22885-096 & 5050 & 1.9 & -3.66 & $\ldots$ & $\ldots$ & 0.60 & $\ldots$ & $\ldots$ & $\ldots$ & 0.52 & -0.78 & 0.44 & $\ldots$ & $\ldots$ & 0.28 & -1.96 & 0.16 & -2.12 & no & 6 \\
\hline S 22891-171 & 5100 & 1.60 & -2.25 & $\ldots$ & $\ldots$ & 1.56 & 1.67 & $<0.79$ & $\ldots$ & 0.70 & $\ldots$ & $\ldots$ & $\ldots$ & $\ldots$ & $\ldots$ & 1.78 & $\ldots$ & $\ldots$ & $\mathrm{b}+$ & 46 \\
\hline S 22892-052 & 4790 & 1.6 & -2.92 & 1.8 & $\ldots$ & 0.91 & & $\ldots$ & $\ldots$ & 0.27 & -0.61 & 0.24 & $\ldots$ & $\ldots$ & 0.26 & & & & & 22 \\
\hline S 22892-052 & 4884 & 1.81 & -2.95 & 1.67 & $\ldots$ & 1.00 & $\ldots$ & $\ldots$ & $\ldots$ & 0.12 & -0.72 & $\ldots$ & $\ldots$ & $\ldots$ & 0.22 & & & & & 26 \\
\hline $92-052$ & 4850 & 1.5 & -2.97 & 2.5 & $\ldots$ & 1.10 & 1.00 & $\ldots$ & $\ldots$ & 0.42 & -0.54 & $\ldots$ & $\ldots$ & $\ldots$ & 0.33 & & & & & 3 \\
\hline-052 & 4760 & 1.3 & -3.04 & 2.29 & $\ldots$ & 0.98 & $\ldots$ & $\ldots$ & 0.11 & 0.32 & -0.57 & 0.79 & $\ldots$ & $\ldots$ & 42 & & & & & 2 \\
\hline & 4800 & 1.5 & -3.1 & 1.95 & 0.15 & 0.88 & 1.01 & 0.72 & -0.19 & 0.30 & -0 . & 0.36 & $\ldots$ & 0.46 & 30 & & & & & 18 \\
\hline 2-052 & 4820 & 1.54 & -3.00 & 1.54 & 0.15 & 0.97 & 1.01 & 0.72 & 0.04 & 0.27 & -0.60 & 0.46 & $\ldots$ & 0.46 & 31 & 0.69 & 1.27 & -0.58 & $\mathrm{r}$ & adopted \\
\hline 3-027 & 6300 & 4.0 & -2.15 & 2.0 & $\ldots$ & 1.95 & 1.20 & $\ldots$ & 0.17 & 0.13 & $\ldots$ & $\ldots$ & $\ldots$ & $\ldots$ & & & & & & 8 \\
\hline 27 & 6250 & 3.7 & -2.26 & 1 & $\ldots$ & 2. & 0.9 & $\ldots$ & $\ldots$ & & -0.86 & $\ldots$ & $\ldots$ & $\ldots$ & & & & & & 12 \\
\hline 027 & 6000 & 3.6 & -2.36 & 1.4 & $\ldots$ & 1.90 & $\ldots$ & $\ldots$ & & 0.09 & -0 & $\ldots$ & $\ldots$ & $\ldots$ & 37 & & & & & 2 \\
\hline 98-027 & 6180 & 3.8 & -2.26 & 1.64 & $\ldots$ & 2.02 & 1.05 & $\ldots$ & 0.32 & 0.21 & -0.66 & $\ldots$ & $\ldots$ & $\ldots$ & 0.39 & 2.18 & 1.74 & 0.44 & rs & adopted \\
\hline 42-019 & 5000 & 2.4 & 2.64 & 2.1 & $\ldots$ & 2.0 & 0.8 & $\ldots$ & $\ldots$ & 0.58 & -0.35 & $\ldots$ & $\ldots$ & $\ldots$ & 0.68 & & & & & 12 \\
\hline-019 & 4900 & 1.8 & 2.67 & 2.0 & $\ldots$ & 2.2 & 0. & $\ldots$ & 1.44 & 0.77 & $\ldots$ & $\ldots$ & $\ldots$ & $\ldots$ & 0.3 & & & & & 8 \\
\hline 942-019 & 5100 & 2.50 & 2.43 & $\ldots$ & $\ldots$ & 2.14 & 1.15 & 0.97 & $\ldots$ & 0.60 & $\ldots$ & $\ldots$ & $\ldots$ & $\ldots$ & $\ldots$ & & & & & 46 \\
\hline S 22942-019 & 4820 & 2.20 & -2.60 & 2.0 & $\ldots$ & 2.1 & 0.9 & 0.97 & 1.44 & 0.65 & -0.35 & $\ldots$ & $\ldots$ & $\ldots$ & 0.68 & 1.08 & 0.15 & 0.93 & $\mathrm{~s}$ & adopted \\
\hline CS 22945-017 & 6400 & 3.80 & -2.52 & $\ldots$ & $\ldots$ & 2.28 & 2.24 & $<2.36$ & $\ldots$ & 0.61 & $\ldots$ & $\ldots$ & $\ldots$ & $\ldots$ & $\ldots$ & -0.06 & $\ldots$ & $\ldots$ & b- & 46 \\
\hline S 22947-187 & 5160 & 1.3 & -2.49 & 2.26 & $\ldots$ & 1.03 & $\ldots$ & $\ldots$ & 0.52 & 0.52 & -0.07 & -0.10 & $\ldots$ & $\ldots$ & 0.49 & 0.66 & 0.21 & 0.45 & $\mathrm{rs}$ & 2 \\
\hline CS 22948-027 & 5000 & 1.9 & -2.21 & 2.0 & $\ldots$ & 2.12 & 2.43 & $\ldots$ & 0.92 & 0.55 & & $\ldots$ & $\ldots$ & $\ldots$ & 0.57 & & & & & 37 \\
\hline S 22948-027 & 4800 & 1.8 & -2.47 & 1.5 & $\ldots$ & 2.43 & 1.75 & $\ldots$ & 0.57 & 0.31 & -0.15 & $\ldots$ & $\ldots$ & $\ldots$ & 0.54 & & & & & 29 \\
\hline-027 & 4800 & 1.8 & -2.47 & 1.2 & $\ldots$ & 2.05 & 1.8 & $\ldots$ & $<0.56$ & 0.39 & $\ldots$ & $\ldots$ & $\ldots$ & $\ldots$ & $\ldots$ & & & & & 5 \\
\hline-027 & 4600 & 0.8 & 2.57 & & $\ldots$ & 2.1 & & . & & 0.35 & $\ldots$ & $\ldots$ & $\ldots$ & $\ldots$ & $\ldots$ & & & & & 8 \\
\hline-027 & 4600 & 1.0 & -2.57 & 2.2 & $<1.0$ & 2.0 & 1 & $\ldots$ & & 0.59 & $\ldots$ & $\ldots$ & $\ldots$ & $\ldots$ & 0.53 & & & & & 10 \\
\hline 48-027 & 4760 & 1.5 & -2.46 & 1.9 & $<1.0$ & 2.14 & 1.78 & $\ldots$ & 0.73 & 0.44 & -0.15 & $\ldots$ & $\ldots$ & $\ldots$ & .55 & 1.63 & 1.41 & 0.22 & rs & adopted \\
\hline-037 & 4900 & 1.7 & -3.79 & 2.0 & $\ldots$ & 1.05 & 2.70 & $\ldots$ & $\ldots$ & 1.22 & -0.43 & 1.04 & $\cdots$ & $\ldots$ & 0.45 & & & & & 6 \\
\hline & 4900 & 1.7 & -3.79 & $\ldots$ & $\ldots$ & & & $\ldots$ & $\ldots$ & $\ldots$ & & $\ldots$ & $\ldots$ & $\ldots$ & $\ldots$ & & & & & 15 \\
\hline-037 & 4900 & 1.7 & -4.0 & 2.0 & $\ldots$ & 1.17 & 2.57 & 1.98 & & 1.58 & -0.16 & 0.72 & $<1.78$ & $<-0.09$ & 0.35 & & & & & 14 \\
\hline-037 & 4915 & 1.7 & 3.79 & 2. & $\ldots$ & 0.97 & 2.1 & 1.96 & & 1.47 & 0.4 & 0.56 & $\ldots$ & $\ldots$ & 0.31 & & & & & 40 \\
\hline S 22949-037 & 4903 & 1.7 & -3.84 & 2.0 & $\ldots$ & 1.06 & 2.43 & 1.97 & 1.77 & 1.42 & -0.04 & 0.77 & $<1.78$ & $<-0.09$ & 0.37 & -2.11 & -0.85 & -1.26 & no & adopted \\
\hline S 22956-028 & 6700 & 3.50 & -2.33 & $\ldots$ & $\ldots$ & 1.84 & 1.85 & $<2.47$ & $\ldots$ & 0.58 & $\ldots$ & $\ldots$ & $\ldots$ & $\ldots$ & $\ldots$ & -0.42 & $\ldots$ & $\ldots$ & b- & 46 \\
\hline CS 22957-027 & 5050 & 2.0 & 2.97 & 2.0 & $\ldots$ & 2.2 & $1 .($ & $\ldots$ & 0.77 & 0.21 & $\cdots$ & $\ldots$ & $\ldots$ & $\ldots$ & $\ldots$ & & & & & 8 \\
\hline S $22957-027$ & 5205 & 2.5 & -3.07 & 1.8 & $\ldots$ & 2.14 & $1.8 \mathrm{~s}$ & $\ldots$ & $\ldots$ & 0.36 & 0.2 & $\ldots$ & $\ldots$ & $\ldots$ & 0.71 & & & & & 31 \\
\hline $957-027$ & 5100 & 1.9 & -3.12 & 1. & $\ldots$ & 2.37 & 1.62 & $\cdots$ & $\ldots$ & 0.69 & -0.77 & $\ldots$ & $\ldots$ & $\ldots$ & 0.14 & & & & & 11 \\
\hline S2957-027 & 5100 & 1.9 & -3.12 & 1. & $\ldots$ & 2.4 & 1.6 & $\cdots$ & $\ldots$ & 0.69 & -0.77 & $\ldots$ & $\ldots$ & $\ldots$ & 0.14 & & & & & 12 \\
\hline S 22957-027 & 5110 & 2.1 & -3.07 & 1.6 & $\ldots$ & 2.28 & 1.68 & $\ldots$ & 0.77 & 0.49 & -0.43 & $\ldots$ & $\ldots$ & $\ldots$ & 0.33 & -1.83 & 0.48 & -2.31 & no & adopted \\
\hline CS 22958-042 & 6250 & 3.5 & -2.85 & 1.5 & $\ldots$ & 3.15 & 2.15 & 1.35 & 2.85 & 0.32 & -0.85 & 0.15 & $\ldots$ & $\ldots$ & 0.36 & -0.85 & $\ldots$ & $\ldots$ & no & 33 \\
\hline S 22960-053 & 5200 & 2.1 & -3.14 & 2.1 & $\ldots$ & 2.05 & 3.06 & $\ldots$ & $\ldots$ & 0.65 & $\ldots$ & $\ldots$ & $\ldots$ & $\ldots$ & 0.43 & 0.21 & $\ldots$ & $\ldots$ & b- & 37 \\
\hline S 22964-161 & 6050 & 3.7 & -2.43 & 1.2 & 2.09 & 1.21 & $\ldots$ & $\ldots$ & 0.00 & 0.36 & -0.90 & 0.14 & $\ldots$ & $\ldots$ & 0.37 & 0.9 & 0.33 & 0.57 & $\mathrm{~s}$ & 42 \\
\hline CS 29497-030 & 7000 & 4.1 & -2.57 & 1.9 & $\ldots$ & 2.47 & 2.12 & 1.48 & 0.58 & 0.44 & $<-0.07$ & 0.03 & $\ldots$ & 1.07 & 0.67 & & & & & 27 \\
\hline CS 29497-030 & 6650 & 3.5 & -2.77 & 2.0 & $<2.7$ & 2.69 & 1.88 & 1.67 & 0.52 & 0.54 & -0.67 & -0.05 & $\ldots$ & $<0.7$ & 0.33 & & & & & 21 \\
\hline CS 29497-030 & 6825 & 3.8 & -2.67 & 1.9 & $\ldots$ & 2.58 & 2.00 & 1.58 & 0.55 & 0.49 & -0.67 & -0.01 & $\ldots$ & 1.07 & 0.50 & 1.76 & 1.23 & 0.53 & $\mathrm{~s}$ & adopted \\
\hline CS 29497-034 & 4800 & 1.8 & -2.90 & 1.5 & $\ldots$ & 2.63 & 2.38 & $\ldots$ & 1.18 & 0.72 & -0.01 & $\ldots$ & $\ldots$ & $\ldots$ & 0.45 & & & & & 29 \\
\hline S 29497-034 & 4800 & 1.8 & -2.91 & 1.5 & $\ldots$ & 2.50 & 2.3 & $\ldots$ & 30 & 0.62 & $\ldots$ & $\ldots$ & $\ldots$ & $\ldots$ & $\ldots$ & & & & & 5 \\
\hline CS 29497-034 & 4900 & 1.5 & -2.91 & 2.2 & $\ldots$ & 2.72 & 2.63 & $\ldots$ & 1.78 & 1.31 & $\ldots$ & $\ldots$ & $\ldots$ & $\ldots$ & 0.52 & & & & & 37 \\
\hline CS 29497-034 & 4830 & 1.7 & -2.90 & 1.7 & $\ldots$ & 2.68 & 2.51 & $\ldots$ & 1.48 & 1.02 & -0.01 & $\ldots$ & $\ldots$ & $\ldots$ & 0.48 & 1.11 & 0.78 & 0.33 & rs & adopted \\
\hline CS 29498-043 & 4600 & 1.2 & -3.54 & 2.4 & $\ldots$ & 2.09 & 2.27 & 2.43 & 1.47 & 1.75 & 0.27 & 0.82 & $\ldots$ & $\ldots$ & 0.16 & & & & & 25 \\
\hline CS 29498-043 & 4400 & 0.6 & -3.75 & 2.3 & $\ldots$ & 1.90 & 2.28 & $\ldots$ & $\ldots$ & 1.81 & 0.34 & 1.07 & $\cdots$ & $\ldots$ & 0.11 & & & & & 11 \\
\hline 8-043 & 4400 & 0.6 & -3.75 & 2.3 & $\ldots$ & 1.9 & 2.3 & $\ldots$ & $\ldots$ & 1.81 & 0.3 & 1.07 & $\ldots$ & $\ldots$ & 0.11 & & & & & 12 \\
\hline S 29498-043 & 4600 & 1.2 & -3.54 & 2.4 & $\ldots$ & 2.09 & 2.27 & 2.43 & 1.47 & 1.75 & 0.27 & 0.82 & $\ldots$ & $\ldots$ & 0.16 & -2.21 & $\ldots$ & $\ldots$ & no & adopted \\
\hline CS 29502-092 & 5000 & 2.1 & -2.76 & 1.8 & $<1.2$ & 1.0 & 0.7 & $\ldots$ & -0.01 & 0.37 & -0.77 & 0.84 & $\ldots$ & $\ldots$ & 0.27 & -1.19 & 0.03 & -1.22 & no & 10 \\
\hline
\end{tabular}


Table B.1. continued.

\begin{tabular}{|c|c|c|c|c|c|c|c|c|c|c|c|c|c|c|c|c|c|c|c|c|}
\hline Star & $\begin{array}{c}T_{\text {eff }} \\
\mathrm{K}\end{array}$ & $\log g$ & {$[\mathrm{Fe} / \mathrm{H}]$} & $\begin{array}{c}\xi \\
\mathrm{km} \mathrm{s}^{-1}\end{array}$ & $\mathrm{~A}(\mathrm{Li})$ & $\mathrm{C}$ & $\mathrm{N}$ & $\mathrm{O}$ & $\mathrm{Na}$ & $\mathrm{Mg}$ & $\mathrm{Al}$ & $\mathrm{Si}$ & S & K & $\mathrm{Ca}$ & $\mathrm{BM}$ & EM & $\mathrm{BE}$ & Cls. & Ref. \\
\hline CS 29503-010 & 6500 & 4.5 & -1.06 & 1.9 & - & 1.07 & $<1.28$ & $\ldots$ & 0.16 & 36 & $\ldots$ & $\ldots$ & $\ldots$ & $\ldots$ & 0.16 & 1.14 & - & $\ldots$ & $\mathrm{b+}$ & 37 \\
\hline $29526-110$ & 6800 & 4.1 & & 2.1 & $<2.3$ & 57 & 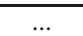 & - & 14 & 22 & & & $\ldots$ & $\ldots$ & 19 & & & & & 41 \\
\hline $26-110$ & 00 & .2 & & 1 & 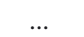 & 2 & 1.4 & & 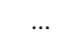 & & -0.78 & & & $\ldots$ & 36 & & & & & 12 \\
\hline $526-110$ & 6800 & 4.1 & 2.07 & 2.1 & $<2.3$ & 2.07 & 1.4 & & 0.14 & .22 & -0.78 & 0.08 & 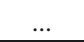 & $\ldots$ & 0.19 & 2.17 & 1.51 & 0.66 & $\mathrm{~s}$ & adopted \\
\hline $28-028$ & 6800 & 4.0 & 2.86 & 1.9 & $\ldots$ & 77 & $<3.58$ & $\ldots$ & 2.68 & 1.69 & $\ldots$ & 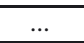 & - & $\ldots$ & 46 & 1.58 & $\ldots$ & $\ldots$ & $\mathrm{b}+$ & 37 \\
\hline $28-041$ & 150 & 4.0 & .30 & 1.3 & & 1.59 & 3.07 & 1.40 & 1.20 & 40 & -0.85 & -0.20 & 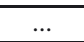 & $\ldots$ & 40 & 0.57 & & & $\mathrm{~b}+$ & 33 \\
\hline-015 & 4750 & 0.8 & .64 & .2 & & 1.6 & 1.7 & 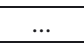 & & 0.86 & 0.15 & $\ldots$ & & 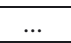 & 77 & 0.59 & -0.66 & 1.25 & $\mathrm{~s}$ & 12 \\
\hline 067 & 4400 & 0.7 & .85 & 2.5 & $<0.6$ & 0.5 & 1.2 & - & -0.08 & .42 & -0.10 & 0.80 & & - & 22 & -0.99 & -0.92 & -0.07 & no & 10 \\
\hline 023 & 4300 & 1.0 & 3.25 & 3.3 & & 0.56 & 2.47 & & 1.04 & 0.54 & & 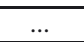 & & - & 30 & 0.05 & 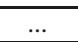 & $\ldots$ & b- & 37 \\
\hline 089 & 5000 & 2.1 & 2.45 & 1.7 & & 2.06 & 1.27 & - & 73 & 0.48 & 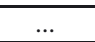 & $\ldots$ & $\ldots$ & $\ldots$ & 51 & 1.74 & & & $\mathrm{~b}+$ & 37 \\
\hline 12 & 6250 & 4.5 & .55 & 1.5 & & 2.1 & 1.2 & & $\ldots$ & 0.45 & -0.68 & $\ldots$ & $\ldots$ & $\ldots$ & & & & & & 12 \\
\hline & 6000 & 3.8 & 74 & & & 2.15 & 1.8 & & $\ldots$ & 0.45 & -0.67 & $\ldots$ & & $\ldots$ & & & & & & 3 \\
\hline & 6000 & 3.8 & 74 & 1.3 & . & 15 & 1.80 & & $\ldots$ & $\ldots$ & $\ldots$ & $\ldots$ & $\ldots$ & $\ldots$ & $\ldots$ & & & & & 9 \\
\hline & 6200 & 4.3 & .53 & 1.4 & 2.3 & 2.14 & $\ldots$ & & 1.12 & 0.42 & $\ldots$ & $\ldots$ & $\ldots$ & $\ldots$ & 0.22 & & & & & 41 \\
\hline 012 & 6200 & 4.3 & -2.53 & 1.4 & 2.3 & 2.14 & 1.2 & . & 1.12 & 0.42 & -0.68 & $\ldots$ & $\ldots$ & $\ldots$ & 0.22 & 1.66 & 1.2 & 0.46 & rs & adopted \\
\hline 550 & 5600 & 3.0 & -2.31 & 1.3 & $\ldots$ & 2.0 & 1.2 & $\ldots$ & $\ldots$ & 0.60 & -0.38 & $\ldots$ & & $\ldots$ & 0.85 & & & & & 12 \\
\hline & 5500 & 2.7 & -2.3 & $\ldots$ & $\ldots$ & $\ldots$ & $\ldots$ & $\ldots$ & $\ldots$ & $\ldots$ & $\ldots$ & $\ldots$ & $\ldots$ & $\ldots$ & $\ldots$ & & & & & 34 \\
\hline & 5500 & 2.70 & 2.42 & 1.3 & $\ldots$ & $\ldots$ & $\ldots$ & $\ldots$ & $\ldots$ & 0.84 & $\ldots$ & $\ldots$ & $\ldots$ & $\ldots$ & 0.49 & & & & & 24 \\
\hline $31062-050$ & 5530 & 2.8 & 2.37 & 1.3 & 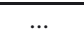 & 2.0 & 1.2 & $\ldots$ & $\ldots$ & 0.72 & -0.38 & $\ldots$ & $\ldots$ & $\ldots$ & 0.67 & 1.98 & 1.13 & 0.85 & $\mathrm{~s}$ & adopted \\
\hline$\overline{095}$ & 6050 & 4.5 & -2.85 & 1.0 & 1.73 & 2.69 & 0.70 & 2.35 & -0.28 & 0.65 & -0.95 & 0.05 & $\ldots$ & $\ldots$ & .17 & -0.6 & $\ldots$ & $\ldots$ & b- & 33 \\
\hline 77-61 & 4000 & 5.05 & 4.03 & 0.1 & $<1$ & 2.6 & 2.6 & $\ldots$ & 0.60 & 0.49 & $\ldots$ & $\ldots$ & $\ldots$ & 1.21 & .37 & 0.51 & 2.51 & -2 & li & 28 \\
\hline 5223 & 4500 & 1.0 & 2.06 & 2.0 & $\ldots$ & 1.57 & $\ldots$ & $\ldots$ & 0.46 & 0.58 & $\cdots$ & $\ldots$ & $\ldots$ & $\ldots$ & 0.10 & 1.24 & $\ldots$ & & $\mathrm{b}+$ & 30 \\
\hline D187216 & 3500 & 0.4 & -2.48 & 3 & 0.00 & 1.30 & $\ldots$ & $\ldots$ & 0.00 & 0.1 & $\begin{array}{l}-0.3 \\
\end{array}$ & $\ldots$ & $\ldots$ & $\ldots$ & 1.20 & 2.4 & $\ldots$ & $\ldots$ & $\mathrm{b+}$ & 1 \\
\hline 7861 & 4600 & 1.70 & -2.36 & $\ldots$ & $\ldots$ & 2.02 & 2.18 & 1.40 & $\ldots$ & 0.37 & 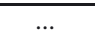 & $\ldots$ & $\ldots$ & $\ldots$ & & 1.02 & $\ldots$ & . & $\mathrm{b}+$ & 46 \\
\hline & 5250 & 1.8 & 2.25 & 1.7 & $\ldots$ & 1.2 & 1.3 & $\ldots$ & $\ldots$ & 0.42 & -0.34 & $\ldots$ & & $\ldots$ & 0.33 & & & & & 12 \\
\hline & 5250 & 1.7 & -2.4 & 2.0 & $\ldots$ & $\ldots$ & $\ldots$ & $\ldots$ & $\ldots$ & $\ldots$ & $\ldots$ & $\ldots$ & $\ldots$ & $\ldots$ & $\ldots$ & & & & & 20 \\
\hline & 5250 & 70 & 2.19 & . & $\ldots$ & 1.30 & 1.41 & 0.63 & $\ldots$ & 0.56 & $\ldots$ & $\ldots$ & $\ldots$ & $\ldots$ & $\ldots$ & & & & & 46 \\
\hline & 5250 & 1.7 & 2.30 & 1.8 & $\ldots$ & 1.25 & 1.35 & 0.63 & $\ldots$ & 0.49 & -0.34 & $\ldots$ & $\ldots$ & $\ldots$ & 0.33 & 0.67 & -0.32 & 0.99 & $\mathrm{~s}$ & adopted \\
\hline & 4500 & 2.0 & $\begin{array}{l}-1.92 \\
\end{array}$ & 2.0 & $\ldots$ & 1.25 & $\ldots$ & $\ldots$ & 0.15 & 0.17 & $\ldots$ & $\ldots$ & $\ldots$ & $\ldots$ & 0.08 & 1.53 & 1.18 & 0.35 & rs & 44 \\
\hline & 4900 & 2.00 & -2.06 & $\ldots$ & $\ldots$ & 1.77 & 1.88 & 1.10 & $\ldots$ & 0.76 & $\ldots$ & $\ldots$ & $\ldots$ & $\ldots$ & $\ldots$ & 1.43 & $\ldots$ & $\ldots$ & $\mathrm{b}+$ & 46 \\
\hline 1441 & 5730 & 3.5 & 2.52 & 1.6 & $\ldots$ & 1.59 & 0.64 & 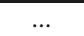 & $\ldots$ & 0.91 & $\ldots$ & $\ldots$ & $\ldots$ & $\ldots$ & 0.42 & 0.24 & & $\ldots$ & $\mathrm{b}+$ & 31 \\
\hline 523 & 6625 & 4.3 & 2.72 & 1.4 & $\ldots$ & 2.6 & 2.1 & 0.40 & -0.17 & 0.73 & -0.35 & 0.34 & $\ldots$ & $\ldots$ & 66 & 0.73 & 0.37 & 0.36 & rs & 17 \\
\hline & 5620 & 3.4 & 2.75 & 1.6 & $\ldots$ & 1.92 & 1.77 & $\ldots$ & $\ldots$ & 0.54 & 0.34 & 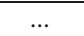 & $\ldots$ & $\ldots$ & 0.96 & 1.5 & 1.16 & 0.34 & rs & 31 \\
\hline & 5100 & 2.2 & 5.30 & 2.2 & $<1.12$ & 4.00 & 2.28 & & 0.81 & 0.15 & $<-0.26$ & $<0.32$ & $<5.06$ & $\ldots$ & $\begin{array}{c}-0.09 \\
\end{array}$ & & & & & 23 \\
\hline & 5100 & 2.2 & -5.30 & & 1.12 & 4.00 & 2.3 & . & 0.80 & 0.20 & $\ldots$ & $\ldots$ & $\ldots$ & $\ldots$ & 0.40 & & & & & 16 \\
\hline & 5100 & 2.2 & -5.30 & 2.2 & $<1.12$ & 4.00 & 2.28 & $\ldots$ & 0.81 & 0.15 & $<-0.26$ & $<0.32$ & $<5.06$ & $\ldots$ & -0.09 & 0.67 & 2.63 & -1.96 & li & dopted \\
\hline 953 & 5928 & 3.83 & 2.71 & 1.06 & $\ldots$ & 2.45 & $\ldots$ & $\ldots$ & $\ldots$ & 0.30 & -0.96 & $\ldots$ & $\ldots$ & $\ldots$ & 0.37 & 1.9 & 1.32 & 0.58 & $\mathrm{~s}$ & 26 \\
\hline 4441 & 240 & 3.7 & 2.31 & 1.6 & $\ldots$ & 1.98 & 1.73 & $\ldots$ & $\ldots$ & 0.63 & -0.22 & $\ldots$ & $\ldots$ & $\ldots$ & 43 & 1.69 & 0.83 & 0.86 & $\mathrm{~s}$ & 31 \\
\hline 204 & 5280 & 1.65 & 1.98 & 2.47 & $\ldots$ & 1.16 & $\ldots$ & $\ldots$ & $\ldots$ & -0.01 & -0.55 & $\ldots$ & $\ldots$ & $\ldots$ & 26 & 1.42 & 0.5 & 0.92 & $\mathrm{~s}$ & 26 \\
\hline & 5200 & 2.7 & 2.09 & 2.0 & $\ldots$ & 2.10 & 1.61 & $\ldots$ & 0.74 & 0.52 & $\ldots$ & $\ldots$ & $\ldots$ & $\ldots$ & 11 & 1.45 & $\ldots$ & $\ldots$ & $\mathrm{b}+$ & 37 \\
\hline 0557 & 5075 & 2.15 & 3.27 & 1.8 & $\ldots$ & 1.74 & 1.09 & $\ldots$ & $\ldots$ & 0.04 & 0.01 & $\ldots$ & $\ldots$ & $\ldots$ & .14 & 2.14 & $\ldots$ & $\ldots$ & $\mathrm{b}+$ & 31 \\
\hline 4016 & 5972 & 3.59 & 2.08 & 1.67 & $\ldots$ & 1.36 & $\ldots$ & $\ldots$ & $\ldots$ & 0.22 & -1.09 & $\ldots$ & $\ldots$ & $\ldots$ & 36 & 1.25 & $\ldots$ & $\ldots$ & $\mathrm{b}+$ & 26 \\
\hline+0113 & 5700 & 3.5 & $\begin{array}{l}-2.68 \\
\end{array}$ & 1.6 & $\ldots$ & 2.25 & 1.60 & $\ldots$ & $\ldots$ & 1.04 & 0.34 & $\ldots$ & $\ldots$ & $\ldots$ & 0.42 & 1.59 & 0.14 & 1.45 & $\mathrm{~s}$ & 31 \\
\hline & 6160 & 4.13 & 2.42 & 1.13 & $\cdots$ & 2.13 & $\ldots$ & $\ldots$ & $\ldots$ & 0.30 & $\begin{array}{l}-0.88 \\
\end{array}$ & $\ldots$ & $\cdots$ & $\ldots$ & 0.38 & & & & & 32 \\
\hline & 6162 & 09 & 2.41 & & . & 2.07 & . & $\ldots$ & $\ldots$ & & -0.69 & & & $\ldots$ & 37 & & & & & 26 \\
\hline & 6160 & 4.10 & 2.41 & 1.23 & $\ldots$ & 2.10 & $\ldots$ & $\ldots$ & $\ldots$ & 0.34 & -0.78 & $\ldots$ & $\cdots$ & $\ldots$ & 37 & 2.07 & 1.57 & 0.5 & rs & adopted \\
\hline & 5600 & 3.5 & 1.73 & 2.2 & $\ldots$ & 1.14 & 2.75 & $\ldots$ & 0.71 & 0.62 & $\ldots$ & $\ldots$ & $\ldots$ & $\ldots$ & 18 & 1.02 & $\ldots$ & $\ldots$ & $b+$ & 37 \\
\hline-4404 & 6214 & 4.27 & 2.07 & 1.41 & $\ldots$ & 1.44 & $\ldots$ & $\ldots$ & $\ldots$ & 0.29 & -0.97 & $\ldots$ & $\ldots$ & $\ldots$ & 33 & 1.33 & $\ldots$ & $\ldots$ & $b+$ & 26 \\
\hline-0652 & 4900 & 1.4 & 2.47 & 2.3 & $\ldots$ & 1.38 & 0.89 & $\ldots$ & 0.72 & 0.35 & $\ldots$ & $\ldots$ & $\ldots$ & $\ldots$ & 31 & 0.76 & $\ldots$ & $\ldots$ & $\mathrm{b}+$ & 37 \\
\hline & 5000 & 2.4 & 1.38 & 2.0 & $\ldots$ & 1.29 & 0.80 & $\ldots$ & 0.43 & 0.19 & $\ldots$ & $\ldots$ & $\ldots$ & $\ldots$ & 58 & 1.7 & $\ldots$ & $\ldots$ & $\mathrm{b}+$ & 37 \\
\hline $7-4840$ & 4900 & 2.2 & -4.75 & 1.8 & $\ldots$ & 1.65 & $<1.47$ & $<3.09$ & -0.16 & 0.25 & -0.61 & $\ldots$ & $\ldots$ & $\ldots$ & 0.25 & -0.22 & 1.79 & -2.01 & li & 38 \\
\hline-0243 & 5000 & 2.00 & 2.88 & $\ldots$ & $\ldots$ & 1.59 & 1.20 & $<1.92$ & $\ldots$ & 0.37 & $\ldots$ & $\ldots$ & $\ldots$ & $\ldots$ & $\ldots$ & 0.04 & $\ldots$ & $\ldots$ & $\mathrm{b}+$ & 46 \\
\hline-1439 & 5000 & 1.9 & -3.17 & 2.0 & $\ldots$ & 2.48 & 1.79 & $\ldots$ & 1.19 & 0.60 & $\ldots$ & $\ldots$ & $\cdots$ & $\ldots$ & 57 & 0.46 & $\ldots$ & $\ldots$ & $\mathrm{b}+$ & 37 \\
\hline-1540 & 5620 & 3.40 & -3.43 & 1.6 & $\ldots$ & 2.22 & 1.25 & 2.25 & 1.21 & 1.88 & 0.93 & 1.07 & $\ldots$ & $\ldots$ & .57 & -2.17 & -0.26 & -1.91 & no & 40 \\
\hline 0020 & 5080 & 2.2 & -3.86 & 1.6 & $\ldots$ & 1.63 & 2.48 & $\ldots$ & $\ldots$ & 0.50 & 0.88 & $\ldots$ & $\ldots$ & $\ldots$ & 12 & 0.71 & 0.37 & 0.34 & rs & 31 \\
\hline+0027 & 6132 & 3.45 & $\begin{array}{l}-2.42 \\
\end{array}$ & 1.52 & $\ldots$ & 2.00 & $\ldots$ & $\ldots$ & $\ldots$ & 0.47 & -0.89 & $\ldots$ & $\ldots$ & $\ldots$ & 47 & 1.98 & 1.34 & 0.64 & $\mathrm{~s}$ & 26 \\
\hline+0139 & 5487 & 1.80 & 2.33 & 2.66 & $\ldots$ & 1.19 & $\ldots$ & $\ldots$ & $\ldots$ & 0.33 & -0.89 & $\ldots$ & $\ldots$ & $\ldots$ & .38 & 0.8 & 0 & 0.8 & $\mathrm{~s}$ & 26 \\
\hline-0344 & 6154 & 4.03 & 2.63 & 1.17 & $\ldots$ & 1.03 & & $\ldots$ & $\ldots$ & $\ldots$ & -1.26 & $\ldots$ & $\ldots$ & $\ldots$ & 27 & $\ldots$ & $\ldots$ & $\ldots$ & $\mathrm{N}$ & 26 \\
\hline 0428 & 5200 & 2.55 & -3.30 & 1.6 & $\cdots$ & 2.37 & 2.52 & $\ldots$ & $\ldots$ & 0.34 & $\cdots$ & $\ldots$ & $\ldots$ & $\ldots$ & .03 & -0.95 & 1.11 & -2.06 & no & 31 \\
\hline-0518 & 4900 & 2.0 & -2.34 & 2.0 & $\ldots$ & 2.15 & 1.56 & $\ldots$ & 0.74 & 0.50 & & $\ldots$ & $\ldots$ & $\ldots$ & .16 & 1.64 & 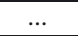 & $\ldots$ & $\mathrm{b}+$ & 37 \\
\hline-1948 & 6083 & 3.81 & -3.36 & 1.65 & $\ldots$ & 1.42 & $\cdots$ & $\ldots$ & $\ldots$ & 0.80 & -0.72 & $\cdots$ & $\ldots$ & $\ldots$ & 81 & $\ldots$ & $\ldots$ & $\ldots$ & $\mathrm{N}$ & 26 \\
\hline & 5373 & 3.40 & -3.23 & 1.58 & $\ldots$ & 1.86 & & $\ldots$ & $\ldots$ & 0.26 & & & $\cdots$ & $\ldots$ & 0.38 & & $\ldots$ & $\ldots$ & $\mathrm{N}$ & 26 \\
\hline & 5632 & 3.37 & & 1.3 & & 1.23 & $<0.71$ & 1.69 & -0.49 & .32 & & & & & & & & & & 40 \\
\hline & 5450 & 3.2 & -3.53 & 1.54 & 1.06 & 0.78 & $<0.62$ & 1.16 & -0.25 & 0.60 & & 0.87 & $\cdots$ & $\ldots$ & & & & & & 36 \\
\hline HE $1300+0157$ & 5411 & 3.38 & -3.76 & 1.43 & $\ldots$ & 1.17 & $\ldots$ & $\ldots$ & $\ldots$ & 0.40 & -0.83 & $\ldots$ & $\ldots$ & $\ldots$ & 0.47 & & & & & 26 \\
\hline
\end{tabular}


D. M. Allen et al.: Elemental abundances and classification of CEMP stars

Table B.1. continued.

\begin{tabular}{|c|c|c|c|c|c|c|c|c|c|c|c|c|c|c|c|c|c|c|c|c|}
\hline Star & $\begin{array}{c}T_{\text {eff }} \\
\mathrm{K}\end{array}$ & $\log g$ & {$[\mathrm{Fe} / \mathrm{H}]$} & $\begin{array}{c}\xi \\
\mathrm{km} \mathrm{s}^{-1}\end{array}$ & $\mathrm{~A}(\mathrm{Li})$ & $\mathrm{C}$ & $\mathrm{N}$ & $\mathrm{O}$ & $\mathrm{Na}$ & $\mathrm{Mg}$ & $\mathrm{Al}$ & $\mathrm{Si}$ & $\mathrm{S}$ & $\mathrm{K}$ & $\mathrm{Ca}$ & BM & EM & $\mathrm{BE}$ & Cls. & Ref. \\
\hline HE $1300+0157$ & 5500 & 3.32 & -3.56 & 1.42 & 1.06 & 1.06 & $<0.65$ & 1.43 & -0.37 & 0.44 & -0.37 & 0.68 & $\ldots$ & $\ldots$ & 0.43 & -1.1 & -2 & 0.9 & li & adopted \\
\hline HE 1300-0641 & 5308 & 2.96 & -3.14 & 1.59 & $\ldots$ & 1.29 & $\ldots$ & $\ldots$ & $\ldots$ & & -1.21 & $\ldots$ & $\ldots$ & $\ldots$ & .01 & -0.81 & $\ldots$ & $\ldots$ & no & 26 \\
\hline $1300-2201$ & 6332 & 4.64 & -2.61 & 1.34 & $\ldots$ & 1.01 & $\ldots$ & $\ldots$ & & & -0.92 & $\ldots$ & 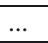 & $\ldots$ & 29 & -0.33 & & $\ldots$ & no & 26 \\
\hline $1305+0007$ & 4750 & 2.0 & -2.03 & 2.0 & 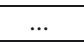 & 1.84 & & $\ldots$ & 0.26 & 0.25 & $\ldots$ & $\ldots$ & - & $\ldots$ & 13 & 2.07 & 1.72 & 0.35 & rs & 30 \\
\hline 1305-0331 & 6081 & 4.22 & -3.26 & 1.58 & & 1.13 & & $\ldots$ & $\ldots$ & $\ldots$ & -0.72 & $\ldots$ & - & $\ldots$ & 0.40 & $\ldots$ & $\ldots$ & $\ldots$ & $\mathrm{N}$ & 26 \\
\hline 19-1935 & 4600 & 1.1 & -1.74 & 2.0 & & 1.45 & 0.46 & 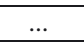 & & 0.47 & $\ldots$ & $\ldots$ & - & $\ldots$ & .50 & 1.42 & & $\ldots$ & $\mathrm{b}+$ & 37 \\
\hline $27-2326$ & 6180 & 3.7 & -5.66 & 1.7 & $<1.6$ & 4.26 & 4.56 & $<4.0$ & 2.15 & 1.66 & 1.73 & $\ldots$ & & $\ldots$ & 0.30 & & & & & 35 \\
\hline 326 & 6180 & 3.7 & -5.96 & 1.7 & $<0.62$ & 3.78 & 4.28 & 3.42 & 2.73 & 1.97 & 1.4 & $\ldots$ & & $\ldots$ & 0.44 & & & & & 39 \\
\hline 326 & 6180 & 3.7 & -5.96 & 1.7 & $<0.62$ & 3.78 & 4.28 & 3.42 & 2.73 & 1.97 & 1.46 & $\ldots$ & $\ldots$ & $\ldots$ & 0.44 & -0.57 & 2.67 & -3.24 & li & adopted \\
\hline $30-0354$ & 6257 & 4.13 & -2.29 & 1.49 & $\ldots$ & 1.05 & $\ldots$ & $\ldots$ & $\ldots$ & 0.32 & -0.93 & $\ldots$ & $\ldots$ & $\ldots$ & 0.40 & -0.79 & $\ldots$ & $\ldots$ & no & 26 \\
\hline 049 & 5204 & 2.85 & 3.46 & 1.48 & $\ldots$ & 1.55 & $\ldots$ & $\ldots$ & $\ldots$ & 0.30 & -0.77 & $\ldots$ & $\ldots$ & $\ldots$ & 32 & -0.17 & $\ldots$ & $\ldots$ & b- & 26 \\
\hline $0-0004$ & 5605 & 3.5 & -3.02 & 1.6 & $<1.32$ & 1.99 & $\ldots$ & 1.18 & 0.48 & 0.58 & $\ldots$ & $\ldots$ & $\ldots$ & 0.71 & 0.11 & 0.48 & 1.82 & -1.34 & $\mathrm{r}$ & 31 \\
\hline 213 & 4985 & 2.0 & -2.16 & 1.8 & $\begin{array}{c}\ldots \\
\end{array}$ & 1.73 & 1.78 & $\ldots$ & $\ldots$ & 0.1 & $\ldots$ & $\ldots$ & & $\ldots$ & $\ldots$ & & & & & 31 \\
\hline 213 & 4800 & 2.00 & .52 & $\ldots$ & $\ldots$ & 2.33 & 2.94 & 2.56 & $\ldots$ & 0.33 & $\ldots$ & $\ldots$ & & $\ldots$ & $\ldots$ & & & & & 46 \\
\hline 213 & 4890 & 2.00 & 2.34 & 1.8 & $\ldots$ & 2.03 & 2.36 & 2.56 & $\ldots$ & 0.25 & $\ldots$ & $\ldots$ & $\ldots$ & $\ldots$ & $\ldots$ & -0.19 & $\ldots$ & $\ldots$ & b- & adopted \\
\hline $13-1954$ & 6533 & 4.59 & -3.22 & 1.40 & $\ldots$ & 1.45 & $\ldots$ & $\ldots$ & $\ldots$ & $\ldots$ & $\ldots$ & $\ldots$ & $\ldots$ & $\ldots$ & 0.33 & $\ldots$ & $\ldots$ & $\ldots$ & $\mathrm{N}$ & 26 \\
\hline 324 & 4900 & 1.80 & -3.05 & $\ldots$ & $\ldots$ & 1.76 & 1.47 & $<1.19$ & $\ldots$ & 0.53 & $\ldots$ & $\ldots$ & $\ldots$ & $\ldots$ & $\ldots$ & 0.35 & $\ldots$ & $\ldots$ & b- & 46 \\
\hline $29-0551$ & 4700 & 1.5 & -2.47 & 2.0 & $\ldots$ & 2.28 & 1.39 & $\ldots$ & 0.95 & 0.52 & $\ldots$ & $\ldots$ & $\ldots$ & $\ldots$ & 0.70 & 1.05 & $\ldots$ & $\ldots$ & $\mathrm{b}+$ & 37 \\
\hline $30-1123$ & 5915 & 3.75 & -2.71 & 1.40 & $\ldots$ & 1.84 & $\ldots$ & $\ldots$ & $\ldots$ & 0.35 & -0.91 & $\ldots$ & $\ldots$ & $\ldots$ & 0.47 & 1.47 & $\ldots$ & $\ldots$ & $\mathrm{b}+$ & 26 \\
\hline HE 1434-1442 & 5420 & 3.15 & -2.39 & 1.6 & $\ldots$ & 1.95 & 1.40 & $\ldots$ & 0.03 & 0.30 & $\ldots$ & 0.74 & $\ldots$ & $\ldots$ & 0.24 & 0.93 & $\ldots$ & $\ldots$ & $\mathrm{b}+$ & 31 \\
\hline HE $1443+0113$ & 4945 & 1.95 & -2.07 & 1.8 & $\ldots$ & 1.84 & $\ldots$ & $\ldots$ & 0.37 & 0.37 & $\ldots$ & $\ldots$ & $\ldots$ & $\ldots$ & $\ldots$ & 1.03 & $\ldots$ & $\ldots$ & $\mathrm{b}+$ & 31 \\
\hline E 1447+0102 & 5100 & 1.7 & -2.47 & 1.8 & $\ldots$ & 2.48 & 1.39 & $\ldots$ & 1.07 & 1.43 & $\ldots$ & $\ldots$ & $\ldots$ & $\ldots$ & 0.88 & 1.27 & $\ldots$ & $\ldots$ & $\mathrm{b}+$ & 37 \\
\hline 99-0806 & 5185 & 2.5 & -2.91 & 1.6 & $\ldots$ & 1.98 & 2.23 & $\ldots$ & $\ldots$ & 0.64 & 0.28 & $\ldots$ & $\ldots$ & $\ldots$ & 0.55 & 1.29 & 0.29 & 1 & $\mathrm{~s}$ & 31 \\
\hline $3-1155$ & 4800 & 1.6 & -2.15 & 1.8 & $\ldots$ & 1.86 & 1.67 & $\cdots$ & $\ldots$ & 0.62 & $\ldots$ & $\ldots$ & $\ldots$ & $\ldots$ & 0.46 & 1.1 & $\ldots$ & $\ldots$ & $\mathrm{b}+$ & 37 \\
\hline-0409 & 5000 & 1.8 & -2.61 & 1.8 & $\ldots$ & 2.42 & 2.03 & $\ldots$ & 1.13 & 0.83 & $\ldots$ & $\ldots$ & $\ldots$ & $\ldots$ & 1.04 & 1.47 & $\ldots$ & $\ldots$ & $\mathrm{b}+$ & 37 \\
\hline 48-1247 & 6380 & 3.9 & -2.30 & 1.7 & $\ldots$ & 1.91 & 1.65 & $\ldots$ & $\ldots$ & 0.50 & -0.76 & 0.69 & $\ldots$ & $\ldots$ & 0.45 & 1.86 & 1.48 & 0.38 & rs & 19 \\
\hline $0-0825$ & 5960 & 3.67 & -1.98 & 1.57 & $\ldots$ & 1.35 & $\ldots$ & $\ldots$ & $\ldots$ & 0.36 & -1.09 & $\ldots$ & $\ldots$ & $\ldots$ & 0.46 & 1.34 & $\ldots$ & $\ldots$ & $\mathrm{b}+$ & 26 \\
\hline 58-0348 & 5215 & 2.5 & -2.70 & 1.6 & $\ldots$ & 1.87 & 1.52 & $\ldots$ & $\ldots$ & 0.68 & 0.47 & $\ldots$ & $\ldots$ & $\ldots$ & 0.82 & 0.91 & 0.12 & 0.79 & $\mathrm{~s}$ & 31 \\
\hline $221-0453$ & 4400 & 0.4 & -2.22 & 2.0 & $\ldots$ & 1.83 & 0.84 & $\ldots$ & $\ldots$ & 0.80 & $\ldots$ & $\ldots$ & $\ldots$ & $\ldots$ & 0.82 & 0.95 & $\ldots$ & $\ldots$ & $\mathrm{b}+$ & 37 \\
\hline $228-0706$ & 5100 & 2.6 & -2.41 & 1.6 & $\ldots$ & 2.32 & 1.13 & $\ldots$ & $\ldots$ & 0.67 & $\ldots$ & $\ldots$ & $\ldots$ & $\ldots$ & 0.47 & 1.83 & $\ldots$ & $\ldots$ & $\mathrm{b}+$ & 37 \\
\hline $232-0603$ & 5750 & 3.5 & -1.85 & 1.6 & $\ldots$ & 1.22 & 0.47 & $\ldots$ & $\ldots$ & 0.85 & 0.26 & $\ldots$ & $\ldots$ & $\ldots$ & 0.35 & 0.56 & $\ldots$ & $\ldots$ & $\mathrm{b}+$ & 31 \\
\hline $0-0412$ & 5852 & 4.33 & -2.20 & 1.30 & $\ldots$ & 1.35 & $\ldots$ & $\ldots$ & $\ldots$ & 0.28 & -0.76 & $\ldots$ & $\ldots$ & $\ldots$ & 0.23 & 0.7 & $\ldots$ & $\ldots$ & $\mathrm{b}+$ & 26 \\
\hline 0555 & 4900 & 1.7 & -2.78 & 1.8 & $\ldots$ & 2.09 & 1.00 & $\ldots$ & 0.97 & 0.67 & $\ldots$ & $\ldots$ & $\ldots$ & $\ldots$ & 0.42 & 0.94 & $\ldots$ & $\ldots$ & $\mathrm{b+}$ & 37 \\
\hline $\begin{array}{l}5-44 \\
\end{array}$ & 5500 & 2.8 & -2.68 & 1.0 & $\ldots$ & 1.95 & 1.65 & $\ldots$ & $\ldots$ & 0.82 & -0.24 & $\ldots$ & $\ldots$ & $\ldots$ & 0.61 & & & & & 3 \\
\hline & 5500 & 2.5 & -2.70 & ??? & $\ldots$ & $\ldots$ & $\ldots$ & $\ldots$ & $\ldots$ & $\ldots$ & $\ldots$ & $\ldots$ & $\ldots$ & $\ldots$ & $\ldots$ & & & & & 34 \\
\hline & 5500 & 2.8 & 2.71 & 1.6 & $\ldots$ & 2.1 & 1.0 & $\ldots$ & $\ldots$ & $\ldots$ & .. & .. & .. & .. & $\ldots$ & & & & & 9 \\
\hline & 5500 & 2.8 & -2.71 & 1.6 & $\ldots$ & $\ldots$ & $\ldots$ & 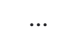 & $\ldots$ & $\ldots$ & $\ldots$ & $\ldots$ & $\ldots$ & $\ldots$ & $\ldots$ & & & & & 4 \\
\hline-44 & 5500 & 2.7 & -2.70 & 1.4 & & 2.1 & 1.0 & $\ldots$ & $\ldots$ & 0.82 & -0.24 & $\ldots$ & $\ldots$ & $\ldots$ & 0.61 & 2.04 & 0.94 & 1.1 & $\mathrm{~s}$ & adopted \\
\hline SSS 0036-10 & 6500 & 4.5 & -2.42 & 1.5 & $<2.0$ & 2.32 & $\ldots$ & $\ldots$ & 0.78 & 0.25 & $\ldots$ & $\ldots$ & $\ldots$ & $\ldots$ & 0.26 & 0.04 & $\ldots$ & $\ldots$ & b- & 41 \\
\hline $26+06$ & 6600 & 4.1 & -3.11 & 2.0 & $<2.2$ & 2.92 & $\ldots$ & $\ldots$ & 0.69 & 0.61 & $\ldots$ & $\ldots$ & $\ldots$ & $\ldots$ & $\ldots$ & 2.14 & $\ldots$ & $\ldots$ & $\mathrm{b}+$ & 41 \\
\hline $17+26$ & 6300 & 4.0 & -3.16 & 1.5 & $<2.3$ & $<2.2$ & $\ldots$ & $\ldots$ & $\ldots$ & 0.43 & $\ldots$ & $\ldots$ & $\ldots$ & $\ldots$ & $\ldots$ & 0.34 & $\ldots$ & $\ldots$ & b- & 41 \\
\hline S $0912+02$ & 6500 & 4.5 & -2.5 & 1.5 & $\ldots$ & 2.17 & 1.75 & $\ldots$ & 0.38 & 0.21 & 0.18 & $\ldots$ & $\ldots$ & $\ldots$ & 0.42 & 1.28 & 0.99 & 0.29 & rs & 45 \\
\hline $24+40$ & 6200 & 4.0 & -2.55 & 1.4 & $<2.0$ & 2.72 & $\ldots$ & $\ldots$ & 1.31 & 0.52 & $\ldots$ & $\ldots$ & $\ldots$ & $\ldots$ & 0.28 & 1.29 & -0.52 & 1.81 & $\mathrm{~b}+$ & 41 \\
\hline SDSS $1036+12$ & 6000 & 4.0 & -3.2 & 1.4 & 2.21 & 1.47 & 1.29 & $\ldots$ & 0.43 & 0.00 & 0.04 & $\ldots$ & $\ldots$ & $\ldots$ & 0.38 & $\ldots$ & $\ldots$ & -0.09 & rs & 45 \\
\hline SDSS 1349-02 & 6200 & 4.0 & -3.0 & 1.5 & $\ldots$ & 2.82 & 1.60 & 1.88 & 1.49 & 0.57 & 0.11 & $\ldots$ & $\ldots$ & $\ldots$ & 0.40 & 1.6 & 1.05 & 0.55 & $\mathrm{~s}$ & 45 \\
\hline SDSS $1707+58$ & 6700 & 4.2 & -2.49 & 1.5 & $<2.5$ & 2.1 & $\ldots$ & $\ldots$ & 2.71 & 1.13 & $\ldots$ & $\ldots$ & $\ldots$ & $\ldots$ & 0.79 & 2.27 & $\ldots$ & $\ldots$ & $\mathrm{b}+$ & 41 \\
\hline SDSS $2047+00$ & 6600 & 4.5 & -2.05 & 1.3 & $<2.3$ & 2.00 & $\ldots$ & $\ldots$ & 0.33 & 0.27 & $\ldots$ & $\ldots$ & $\ldots$ & $\ldots$ & 0.32 & -0.03 & $\ldots$ & $\ldots$ & b- & 41 \\
\hline
\end{tabular}

Notes. The $\mathrm{Li}$ abundance is $\mathrm{A}(\mathrm{Li})=\log \epsilon(\mathrm{Li})+12.0$. The last 5 columns are: $\mathrm{BM}=[\mathrm{Ba} / \mathrm{Mg}] ; \mathrm{EM}=[\mathrm{Eu} / \mathrm{Mg}] ; \mathrm{BE}=[\mathrm{Ba} / \mathrm{Eu}] ; \mathrm{Cls}$. $=$ classification of CEMP stars according to Beers \& Christlieb (2005): $\mathrm{s}=$ CEMP-s, $r=$ CEMP-r, rs $=$ CEMP-rs, no $=$ CEMP-no, $b+=$ stars with $[\mathrm{Ba} / \mathrm{Fe}]>1$ with no Eu abundance, $\mathrm{b}-=$ stars with $0<[\mathrm{Ba} / \mathrm{Fe}]<1$ with no Eu abundance, $\mathrm{N}=$ stars with no $\mathrm{Ba}$ and Eu abundances, li = stars with only an upper limit for both, Eu and Ba abundances; Ref. = abundance references, as enumerated below. The word "adopted" for stars with more than one reference indicates that the adopted value is the average or one of the references above, according to criteria explained in the text. Some stars are found in the literature with different IDs: HE 2148-1247 = CS 22944-0068, HE 0058-0244 = CS 22183-0015, CS 31062-012 = LP 706-7, G77-61 = HE 0330+0148, CS 31062-050 = HE 0027-1221, CS 29497-034 = HE 0039-2635, CS 22957-027 = HE 2356-0410, CS 22948-027 = HE 21343940, CS 22949-037 = HE 2323-0256, CS 22942-019 = HE 0054-2542, CS 22892-052 = HE 2214-1654, BS 17435-0532 = HKII $17435-00532$.

References. (1) Kipper \& Jorgensen (1994); (2) McWilliam et al. (1995); (3) Norris et al. (1997); (4) Aoki et al. (2000); (5) Hill et al. (2000); (6) Norris et al. (2001); (7) Giridhar et al. (2001); (8) Preston \& Sneden (2001); (9) Aoki et al. (2001); (10) Aoki et al. (2002a); (11) Aoki et al. (2002b); (12) Aoki et al. (2002c); (13) Aoki et al. (2002d); (14) Depagne et al. (2002); (15) Norris et al. (2002); (16) Christlieb et al. (2002); (17) Lucatello et al. (2003); (18) Sneden et al. (2003); (19) Cohen et al. (2003); (20) Van Eck et al. (2003); (21) Sivarani et al. (2004); (22) Honda et al. (2004); (23) Christlieb et al. (2004); (24) Johnson \& Bolte (2004); (25) Aoki et al. (2004); (26) Barklem et al. (2005); (27) Ivans et al. (2005); (28) Plez \& Cohen (2005); (29) Barbuy et al. (2005); (30) Goswami et al. (2006); (31) Cohen et al. (2006); (32) Jonsell et al. (2006); (33) Sivarani et al. (2006); (34) Aoki et al. (2006a); (35) Aoki et al. (2006b); (36) Frebel et al. (2007); (37) Aoki et al. (2007); (38) Norris et al. (2007); (39) Frebel et al. (2008); (40) Cohen et al. (2008); (41) Aoki et al. (2008); (42) Thompson et al. (2008); (43) Roederer et al. (2008); (44) Goswami \& Aoki (2010); (45) Behara et al. (2010); (46) Masseron et al. (2010). 
A\&A 548, A34 (2012)

Table B.2. Abundances $[\mathrm{X} / \mathrm{Fe}]$ of iron-peak elements for CEMP stars.

\begin{tabular}{|c|c|c|c|c|c|c|c|c|c|c|c|}
\hline Star & {$[\mathrm{Fe} / \mathrm{H}]$} & $\mathrm{Sc}$ & $\mathrm{Ti}$ & V & $\mathrm{Cr}$ & $\mathrm{Mn}$ & $\mathrm{Co}$ & $\mathrm{Ni}$ & $\mathrm{Cu}$ & $\mathrm{Zn}$ & Ref. \\
\hline BS 16929-005 & -3.09 & -0.53 & 0.42 & $\ldots$ & & -0.74 & 0.36 & -0.09 & $\ldots$ & $\ldots$ & 22 \\
\hline BS 16929-005 & -3.17 & & $0.44 *$ & $\ldots$ & -0.34 & & & & $\ldots$ & $\ldots$ & 37 \\
\hline BS 16929-005 & -3.17 & -0.53 & 0.42 & $\ldots$ & -0.34 & -0.74 & 0.36 & -0.09 & $\ldots$ & $\ldots$ & adopted \\
\hline BS 17435-532 & -2.2 & 0.20 & 0.22 & $\ldots$ & -0.15 & -0.31 & $\ldots$ & 0.11 & $\ldots$ & $\ldots$ & 43 \\
\hline CS 22166-016 & -2.40 & 0.48 & 0.18 & $\ldots$ & -0.85 & $\ldots$ & $\ldots$ & 0.17 & $\ldots$ & $\ldots$ & 7 \\
\hline CS 22877-001 & -2.72 & -0.04 & 0.15 & $\ldots$ & -0.29 & -0.38 & 0.39 & -0.25 & $\ldots$ & $\ldots$ & 10 \\
\hline CS 22877-001 & -2.82 & -0.13 & 0.16 & $\ldots$ & -0.18 & $\ldots$ & 0.35 & -0.07 & $\ldots$ & $\ldots$ & 7 \\
\hline CS 22877-001 & -2.72 & -0.04 & 0.15 & $\ldots$ & -0.29 & -0.38 & 0.39 & -0.25 & $\ldots$ & $\ldots$ & adopted \\
\hline CS 22880-074 & -1.76 & $\ldots$ & 0.10 & $\ldots$ & & & $\ldots$ & & $\ldots$ & $\ldots$ & 8 \\
\hline $80-074$ & -1.93 & $\ldots$ & 0.41 & $\ldots$ & 0.20 & -0.60 & $\ldots$ & 0.13 & $\ldots$ & $\ldots$ & 12 \\
\hline CS 22880-074 & -1.85 & $\ldots$ & 0.26 & $\ldots$ & 0.20 & -0.60 & $\ldots$ & 0.13 & $\ldots$ & $\ldots$ & adopted \\
\hline CS 22881-036 & -2.06 & $\ldots$ & 0.33 & $\ldots$ & $\ldots$ & $\ldots$ & $\ldots$ & $\ldots$ & $\ldots$ & $\ldots$ & 8 \\
\hline CS 22885-096 & -3.66 & 0.15 & 0.12 & $\ldots$ & -0.59 & -0.79 & 0.59 & 0.18 & $\ldots$ & $\ldots$ & 6 \\
\hline CS 22891-171 & -2.25 & $\ldots$ & $\ldots$ & $\ldots$ & $\ldots$ & $\ldots$ & $\ldots$ & $\ldots$ & $\ldots$ & $\ldots$ & 46 \\
\hline CS 22892-052 & -2.92 & -0.08 & 0.08 & -0.01 & & -0.33 & 0.12 & -0.28 & $\ldots$ & $\ldots$ & 22 \\
\hline $92-052$ & -2.95 & -0.01 & 0.05 & $\ldots$ & -0.47 & -0.67 & 0.02 & 0.09 & $\ldots$ & $\ldots$ & 26 \\
\hline 392-052 & -2.97 & -0.20 & 0.19 & $\ldots$ & -0.74 & -0.81 & 0.29 & 0.20 & $\ldots$ & $\ldots$ & 3 \\
\hline $\mathrm{CS} 2$ & -3.04 & -0.12 & 0.25 & $\ldots$ & -0.23 & -0.28 & 0.14 & 0.14 & $\ldots$ & $\ldots$ & 2 \\
\hline CS 2 & -3.1 & -0.22 & 0.20 & -0.05 & -0.24 & -0.53 & 0.20 & -0.07 & -0.66 & 0.09 & 18 \\
\hline CS 22 & -3.00 & -0.13 & 0.15 & -0.03 & -0.42 & -0.52 & 0.15 & -0.02 & -0.66 & 0.09 & adopted \\
\hline$\overline{C S} 2$ & -2.15 & $\ldots$ & 0.23 & $\ldots$ & & 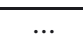 & $\ldots$ & 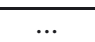 & $\ldots$ & $\ldots$ & 8 \\
\hline $\mathrm{CS} 2$ & -2.26 & $\ldots$ & 0.41 & $\ldots$ & -0.10 & -0.58 & $\ldots$ & 0.02 & $\ldots$ & $\ldots$ & 12 \\
\hline CS 22898-027 & -2.36 & 0.24 & 0.79 & $\ldots$ & -0.42 & -0.62 & 0.20 & 0.53 & $\ldots$ & $\cdots$ & 2 \\
\hline CS 22898-027 & -2.26 & 0.24 & 0.48 & $\ldots$ & -0.26 & -0.60 & 0.20 & 0.28 & $\ldots$ & $\ldots$ & adopted \\
\hline CS 22942-019 & -2.64 & $\ldots$ & 0.39 & $\ldots$ & $\ldots$ & $\ldots$ & $\ldots$ & $\ldots$ & $\ldots$ & 0.41 & 12 \\
\hline CS 22942-019 & -2.67 & $\ldots$ & 0.15 & $\ldots$ & $\ldots$ & $\ldots$ & $\ldots$ & $\ldots$ & $\ldots$ & $\ldots$ & 8 \\
\hline $\mathrm{CS} 2$ & -2.43 & $\ldots$ & 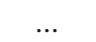 & $\ldots$ & $\ldots$ & $\ldots$ & $\ldots$ & $\ldots$ & $\ldots$ & $\ldots$ & 46 \\
\hline CS 22942-019 & -2.66 & $\ldots$ & 0.27 & $\ldots$ & $\ldots$ & $\ldots$ & $\ldots$ & $\ldots$ & $\ldots$ & 0.41 & adopted \\
\hline CS 22945-017 & -2.52 & $\ldots$ & $\ldots$ & $\ldots$ & $\ldots$ & $\ldots$ & $\ldots$ & $\ldots$ & $\ldots$ & $\ldots$ & 46 \\
\hline CS 22947-187 & -2.49 & -0.08 & 0.37 & 0.39 & 0.05 & -0.15 & -0.04 & 0.22 & $\ldots$ & $\ldots$ & 2 \\
\hline CS 22948-027 & -2.21 & $\ldots$ & 0.60 & $\ldots$ & -0.12 & $\ldots$ & $\ldots$ & $\ldots$ & $\ldots$ & 0.31 & 37 \\
\hline CS 22948-027 & -2.47 & $\ldots$ & 0.34 & $\ldots$ & -0.15 & $\ldots$ & $\ldots$ & -0.01 & $\ldots$ & 0.36 & 29 \\
\hline $\mathrm{CS} 2$ & -2.47 & $\ldots$ & 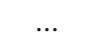 & $\ldots$ & $\ldots$ & $\ldots$ & $\ldots$ & $\ldots$ & $\ldots$ & $\ldots$ & 5 \\
\hline CS 22948-027 & -2.57 & $\ldots$ & 0.15 & $\ldots$ & $\ldots$ & $\ldots$ & $\ldots$ & $\ldots$ & $\ldots$ & $\ldots$ & 8 \\
\hline $948-027$ & -2.57 & $\ldots$ & $\cdots$ & $\ldots$ & 0.22 & $\ldots$ & $\ldots$ & $\ldots$ & $\ldots$ & $\ldots$ & 10 \\
\hline CS 22948-027 & -2.46 & $\ldots$ & 0.36 & $\ldots$ & -0.02 & $\ldots$ & $\ldots$ & -0.01 & $\ldots$ & 0.34 & adopted \\
\hline CS 22949-037 & -3.79 & 0.13 & 0.35 & $\ldots$ & -0.55 & -0.92 & 0.58 & 0.06 & $\ldots$ & $\cdots$ & 6 \\
\hline $\mathrm{CS} 22$ & -3.79 & $\ldots$ & $\ldots$ & $\ldots$ & $\ldots$ & $\ldots$ & $\ldots$ & $\ldots$ & $\ldots$ & $\ldots$ & 15 \\
\hline $\mathrm{CS} 2$ & -4.0 & 0.10 & 0.35 & $\ldots$ & -0.41 & -0.81 & 0.33 & -0.07 & $\ldots$ & 0.70 & 14 \\
\hline CS 2 & -3.79 & 0.12 & $<0.46$ & 0.09 & -0.54 & -0.97 & 0.42 & -0.26 & -0.78 & $\ldots$ & 40 \\
\hline $9-037$ & -3.84 & 0.12 & 0.35 & 0.09 & -0.50 & -0.90 & 0.44 & -0.09 & -0.78 & 0.70 & adopted \\
\hline CS 22956-028 & -2.33 & $\ldots$ & $\ldots$ & $\ldots$ & $\ldots$ & $\ldots$ & $\ldots$ & $\ldots$ & $\ldots$ & $\ldots$ & 46 \\
\hline CS 22957-027 & -2.97 & $\ldots$ & 0.15 & $\ldots$ & $\ldots$ & $\ldots$ & $\ldots$ & $\ldots$ & $\ldots$ & $\ldots$ & 8 \\
\hline $\mathrm{CS} 2$ & -3.07 & 0.48 & 0.25 & $\ldots$ & -0.36 & -0.10 & 0.18 & $\ldots$ & $\ldots$ & 0.51 & 31 \\
\hline 027 & -3.12 & $\ldots$ & 0.30 & $\ldots$ & -0.21 & -0.41 & $\ldots$ & -0.25 & $\ldots$ & $\ldots$ & 11 \\
\hline 027 & -3.12 & $\ldots$ & 0.30 & $\ldots$ & -0.21 & -0.41 & $\ldots$ & -0.25 & $\ldots$ & $\ldots$ & 12 \\
\hline CS 2295 & -3.07 & 0.48 & 0.25 & $\ldots$ & -0.26 & -0.31 & 0.18 & -0.25 & $\ldots$ & 0.51 & adopted \\
\hline CS 22958-042 & -2.85 & 0.05 & 0.43 & -0.05 & -0.15 & -0.21 & 0.20 & -0.09 & $\ldots$ & $\ldots$ & 33 \\
\hline CS 22960-053 & -3.14 & 0.49 & $0.54^{*}$ & $\ldots$ & -0.23 & $\ldots$ & $\ldots$ & $\ldots$ & $\ldots$ & $\ldots$ & 37 \\
\hline CS 22964-161 & -2.43 & $\ldots$ & $0.60^{*}$ & $\ldots$ & 0.04 & -0.71 & $\ldots$ & 0.07 & $\ldots$ & $\ldots$ & 42 \\
\hline CS 29497-030 & -2.57 & 0.67 & 0.64 & $\ldots$ & 0.03 & -0.35 & $<1.67$ & 0.04 & $\ldots$ & $\ldots$ & 27 \\
\hline CS 29 & -2.77 & 0.30 & 0.16 & $\ldots$ & -0.17 & -0.19 & 0.42 & -0.21 & $\ldots$ & $<-0.10$ & 21 \\
\hline CS 29497-030 & -2.67 & 0.49 & 0.40 & $\ldots$ & -0.07 & -0.27 & 0.42 & -0.09 & $\ldots$ & $<-0.10$ & adopted \\
\hline CS 29497-034 & -2.90 & $\ldots$ & 0.29 & $\ldots$ & -0.23 & $\ldots$ & $\ldots$ & 0.01 & $\ldots$ & 0.46 & 29 \\
\hline CS 29497-034 & -2.91 & $\ldots$ & 0.52 & $\ldots$ & -0.15 & $\ldots$ & $\ldots$ & $\ldots$ & $\ldots$ & $\ldots$ & 37 \\
\hline 497-034 & -2.91 & $\ldots$ & $\ldots$ & $\ldots$ & $\ldots$ & $\ldots$ & $\ldots$ & $\ldots$ & $\ldots$ & $\ldots$ & 5 \\
\hline CS 29497-034 & -2.90 & $\ldots$ & 0.40 & $\ldots$ & -0.19 & $\ldots$ & $\ldots$ & 0.01 & $\ldots$ & 0.46 & adopted \\
\hline CS 29498-043 & -3.54 & -0.03 & 0.22 & $\ldots$ & -0.38 & -1.09 & 0.06 & -0.36 & $\ldots$ & $<0.5$ & 25 \\
\hline CS 29498-043 & -3.75 & $\ldots$ & 0.12 & .. & -0.32 & -0.68 & $\ldots$ & $\ldots$ & $\ldots$ & $\ldots$ & 12 \\
\hline $98-043$ & -3.75 & 0.13 & 0.12 & $\ldots$ & -0.32 & -0.68 & $\ldots$ & $\ldots$ & $\ldots$ & $\ldots$ & 11 \\
\hline CS 29498-043 & -3.54 & -0.03 & 0.22 & $\ldots$ & -0.38 & -1.09 & 0.06 & -0.36 & $\ldots$ & $<0.5$ & adopted \\
\hline CS 29502-092 & -2.76 & -0.02 & 0.19 & $\ldots$ & $\ldots$ & -0.59 & 0.27 & 0.16 & $\ldots$ & $\ldots$ & 10 \\
\hline CS 29503-010 & -1.06 & 0.31 & 0.39 & $\ldots$ & -0.12 & $\ldots$ & $\ldots$ & 0.01 & $\ldots$ & 0.32 & 37 \\
\hline CS 29 & -2.07 & $\ldots$ & 0.54 & $\cdots$ & -0.05 & .. &. & 0.35 & $\cdots$ & $\cdots$ & 41 \\
\hline CS 29526-110 & -2.38 & $\ldots$ & $0.12 *$ & $\ldots$ & -0.33 & -0.92 & $\ldots$ & -0.11 & $\ldots$ & $\ldots$ & 12 \\
\hline
\end{tabular}


D. M. Allen et al.: Elemental abundances and classification of CEMP stars

Table B.2. continued.

\begin{tabular}{|c|c|c|c|c|c|c|c|c|c|c|c|}
\hline Star & {$[\mathrm{Fe} / \mathrm{H}]$} & $\mathrm{Sc}$ & $\mathrm{Ti}$ & V & $\mathrm{Cr}$ & Mn & Co & $\mathrm{Ni}$ & $\mathrm{Cu}$ & $\mathrm{Zn}$ & Ref. \\
\hline CS 29526-110 & -2.07 & 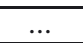 & 0.54 & $\ldots$ & -0.05 & -0.92 & $\ldots$ & 0.35 & $\ldots$ & $\ldots$ & adopted \\
\hline CS 29528-028 & -2.86 & 0.59 & $0.87 *$ & $\ldots$ & $\ldots$ & $\ldots$ & $\ldots$ & 0.26 & $\ldots$ & $\ldots$ & 37 \\
\hline CS 29528-041 & -3.30 & 0.26 & 0.40 & 0.00 & -0.17 & -0.50 & 0.00 & 0.00 & $\ldots$ & 工 & 33 \\
\hline CS 30301-015 & -2.64 & $\ldots$ & 0.23 & $\ldots$ & $\ldots$ & $\ldots$ & $\ldots$ & $\ldots$ & $\ldots$ & 0.33 & 12 \\
\hline CS 30314-067 & -2.85 & 0.02 & 0.12 & $\ldots$ & -0.38 & -0.69 & -0.08 & -0.10 & $\ldots$ & $\ldots$ & 10 \\
\hline CS 30322-023 & -3.25 & 0.28 & 0.07 & $\ldots$ & -0.36 & $\ldots$ & $\ldots$ & $\ldots$ & $\ldots$ & & 37 \\
\hline CS 30338-089 & -2.45 & 1.26 & 0.33 & $\ldots$ & -0.01 & $\ldots$ & $\ldots$ & $\ldots$ & $\ldots$ & 0.46 & 37 \\
\hline CS 31062-012 & -2.55 & & 0.36 & & -0.23 & -0.68 & & -0.02 & $\cdots$ & ... & 12 \\
\hline CS 31062-012 & -2.74 & -0.16 & 0.41 & $\ldots$ & -0.04 & -0.63 & 0.14 & -0.11 & $\ldots$ & $\ldots$ & 3 \\
\hline CS 31062-012 & -2.74 & . & . & $\ldots$ & $\ldots$ & $\ldots$ & . & $\ldots$ & $\ldots$ & & 9 \\
\hline CS 31062-012 & -2.53 & 0.20 & 0.55 & $\ldots$ & -0.07 & $\ldots$ & 0.21 & 0.07 & $\ldots$ & 0.00 & 41 \\
\hline CS 31062-012 & -2.53 & 0.20 & 0.55 & $\ldots$ & -0.07 & -0.68 & 0.21 & 0.07 & $\ldots$ & 0.00 & adopted \\
\hline CS 31062-050 & -2.31 & $\ldots$ & 0.42 & $\ldots$ & -0.02 & -0.21 & $\ldots$ & $\ldots$ & $\ldots$ & $\ldots$ & 12 \\
\hline CS 31062-050 & -2.3 & $\ldots$ & $\ldots$ & $\ldots$ & $\ldots$ & $\ldots$ & $\ldots$ & $\ldots$ & $\ldots$ & & 34 \\
\hline CS 31062-050 & -2.42 & $\ldots$ & 0.32 & -0.17 & 0.08 & -0.43 & 0.10 & -0.16 & -1.19 & 0.06 & 24 \\
\hline CS 31062-050 & -2.37 & $\ldots$ & 0.37 & -0.17 & 0.03 & -0.33 & 0.10 & -0.16 & -1.19 & 0.06 & adopted \\
\hline CS 31080-095 & -2.85 & -0.02 & $\overline{0.42}$ & 0.00 & 0.02 & -0.21 & 0.31 & 0.09 & $\ldots$ & 0.58 & 33 \\
\hline G77-61 & -4.03 & $\ldots$ & $\ldots$ & $\ldots$ & 0.36 & -0.06 & $\ldots$ & $\ldots$ & $\ldots$ & $<2.7$ & 28 \\
\hline HD 5223 & -2.06 & $\ldots$ & 0.49 & $\ldots$ & $\ldots$ & $\ldots$ & $\ldots$ & -0.47 & $\ldots$ & $\ldots$ & 30 \\
\hline HD 187216 & -2.48 & 1.60 & -0.50 & -0.30 & -1.00 & 0.90 & 0.10 & 0.40 & $\ldots$ & $\ldots$ & 1 \\
\hline HD 187861 & -2.36 & $\ldots$ & $\ldots$ & $\ldots$ & $\ldots$ & $\ldots$ & $\ldots$ & $\ldots$ & $\ldots$ & $\ldots$ & 46 \\
\hline HD 196944 & -2.25 & $\ldots$ & 0.27 & $\ldots$ & -0.13 & -0.05 & 0.12 & 0.02 & $\ldots$ & 0.09 & 12 \\
\hline HD 196944 & -2.4 & $\ldots$ & $\ldots$ & $\ldots$ & $\ldots$ & $\ldots$ & $\ldots$ & $\ldots$ & $\ldots$ & $\ldots$ & 20 \\
\hline HD 196944 & -2.19 & $\ldots$ & $\ldots$ & $\ldots$ & $\ldots$ & $\ldots$ & $\ldots$ & $\ldots$ & $\ldots$ & $\ldots$ & 46 \\
\hline HD 196944 & -2.33 & $\ldots$ & 0.27 & $\ldots$ & -0.13 & -0.05 & 0.12 & 0.02 & $\ldots$ & 0.09 & adopted \\
\hline HD 209621 & -1.92 & 0.79 & $0.72 *$ & $\ldots$ & -0.20 & $\ldots$ & $\ldots$ & -0.01 & $\ldots$ & 0.24 & 44 \\
\hline HD 224959 & -2.06 & $\ldots$ & $\ldots$ & $\ldots$ & $\ldots$ & $\ldots$ & $\ldots$ & $\ldots$ & $\ldots$ & $\ldots$ & 46 \\
\hline HE 0012-1441 & -2.52 & $\ldots$ & 0.03 & $\ldots$ & -0.18 & $\ldots$ & $\ldots$ & $\ldots$ & $\ldots$ & $\ldots$ & 31 \\
\hline HE 0024-2523 & -2.72 & 0.37 & 0.15 & $\ldots$ & -0.41 & -0.26 & $\ldots$ & $\ldots$ & $\ldots$ & $\ldots$ & 17 \\
\hline HE 0058-0244 & -2.75 & 0.56 & 0.57 & $\ldots$ & -0.35 & -0.39 & 0.17 & -0.33 & $\ldots$ & $\ldots$ & 31 \\
\hline HE 0107-5240 & -5.30 & $\ldots$ & -0.40 & $\ldots$ & $\ldots$ & $\ldots$ & & -0.40 & $\ldots$ & $<2.70$ & 16 \\
\hline HE 0107-5240 & -5.30 & $<0.61$ & -0.36 & $\ldots$ & $<0.26$ & $<0.36$ & $<1.22$ & -0.37 & $\ldots$ & $<2.65$ & 23 \\
\hline HE 0107-5240 & -5.30 & $<0.61$ & -0.36 & $\ldots$ & $<0.26$ & $<0.36$ & $<1.22$ & -0.37 & $\ldots$ & $<2.65$ & adopted \\
\hline HE 0131-3953 & -2.71 & 0.59 & 0.13 & $\ldots$ & -0.21 & -0.53 & $\ldots$ & -0.28 & $\ldots$ & $\ldots$ & 26 \\
\hline HE 0143-0441 & -2.31 & 0.67 & 0.54 & $\ldots$ & -0.38 & -0.72 & 0.47 & -0.31 & $\ldots$ & 0.46 & 31 \\
\hline HE 0202-2204 & -1.98 & -0.04 & -0.06 & $\ldots$ & -0.40 & -0.33 & 0.03 & 0.04 & $\ldots$ & 0.57 & 26 \\
\hline HE 0206-1916 & -2.09 & $\ldots$ & 0.41 & $\ldots$ & 0.00 & $\ldots$ & $\ldots$ & $\ldots$ & $\ldots$ & $\ldots$ & 37 \\
\hline HE 0212-0557 & -3.27 & $\ldots$ & 0.14 & $\ldots$ & -0.09 & -0.55 & $\ldots$ & $\ldots$ & $\ldots$ & $\ldots$ & 31 \\
\hline HE 0231-4016 & -2.08 & -0.01 & 0.25 & $\ldots$ & -0.11 & -0.28 & -0.12 & -0.14 & $\ldots$ & $\ldots$ & 26 \\
\hline HE $0336+0113$ & -2.68 & $\ldots$ & 0.39 & $\ldots$ & -0.26 & -0.21 & 0.15 & $\ldots$ & $\ldots$ & $\ldots$ & 31 \\
\hline HE 0338-3945 & -2.42 & 0.53 & 0.37 & 0.19 & -0.12 & -0.49 & 0.23 & 0.01 & .. & $\ldots$ & 32 \\
\hline HE 0338-3945 & -2.41 & 0.48 & 0.41 & $\ldots$ & -0.04 & -0.48 & $\ldots$ & -0.08 & $\ldots$ & $\ldots$ & 26 \\
\hline HE 0338-3945 & -2.41 & 0.50 & 0.39 & 0.19 & -0.08 & -0.48 & 0.23 & -0.04 & $\ldots$ & $\ldots$ & adopted \\
\hline HE 0400-2030 & -1.73 & 0.32 & 0.27 & $\ldots$ & -0.08 & $\ldots$ & $\ldots$ & -0.10 & $\ldots$ & -0.20 & 37 \\
\hline HE 0430-4404 & -2.07 & 0.19 & 0.32 & $\ldots$ & -0.02 & -0.47 & 0.10 & 0.01 & $\ldots$ & $\ldots$ & 26 \\
\hline HE 0441-0652 & -2.47 & 0.14 & 0.34 & $\ldots$ & -0.26 & $\ldots$ & $\ldots$ & 0.12 & $\ldots$ & 0.17 & 37 \\
\hline HE 0507-1653 & -1.38 & 0.20 & 0.47 & $\ldots$ & 0.07 & $\ldots$ & $\ldots$ & 0.25 & $\ldots$ & 0.12 & 37 \\
\hline HE 0557-4840 & -4.75 & 0.31 & $0.35^{*}$ & $\ldots$ & -0.70 & $<-0.63$ & 0.04 & -0.22 & $\ldots$ & $\ldots$ & 38 \\
\hline HE 1001-0243 & -2.88 & $\ldots$ & $\ldots$ & $\ldots$ & $\ldots$ & $\ldots$ & $\ldots$ & $\ldots$ & $\ldots$ & $\ldots$ & 46 \\
\hline HE 1005-1439 & -3.17 & $\ldots$ & 0.48 & $\ldots$ & -0.38 & $\ldots$ & $\ldots$ & $\ldots$ & $\ldots$ & $\ldots$ & 37 \\
\hline HE 1012-1540 & -3.43 & $\ldots$ & $<0.74$ & $\ldots$ & -0.31 & -0.55 & 0.19 & -0.32 & -0.63 & $\ldots$ & 40 \\
\hline HE 1031-0020 & -3.86 & $\ldots$ & 0.46 & $\ldots$ & -0.38 & 0.03 & $\ldots$ & $\ldots$ & $\ldots$ & $\ldots$ & 31 \\
\hline HE $1105+0027$ & -2.42 & 0.28 & 0.32 & $\ldots$ & 0.05 & -0.51 & $\ldots$ & -0.29 & $\ldots$ & $\ldots$ & 26 \\
\hline HE $1135+0139$ & -2.33 & 0.15 & 0.14 & 0.03 & -0.24 & -0.44 & 0.14 & 0.01 & $\ldots$ & $\ldots$ & 26 \\
\hline HE $1135-0344$ & -2.63 & 0.18 & 0.45 & $\ldots$ & -0.22 & -0.67 & 0.30 & -0.14 & $\ldots$ & $\ldots$ & 26 \\
\hline HE 1150-0428 & -3.30 & $\ldots$ & 0.49 & $\ldots$ & -0.70 & $\ldots$ & $\ldots$ & $\ldots$ & $\ldots$ & $\ldots$ & 31 \\
\hline HE $1157-0518$ & -2.34 & $\ldots$ & 0.10 & $\ldots$ & -0.28 & $\ldots$ & $\ldots$ & $\ldots$ & $\ldots$ & $\ldots$ & 37 \\
\hline HE 1221-1948 & -3.36 & 0.29 & 0.52 & $\ldots$ & -0.19 & $\ldots$ & $\ldots$ & -0.10 & $\ldots$ & $\ldots$ & 26 \\
\hline HE 1249-3121 & -3.23 & 0.59 & 0.43 & $\ldots$ & -0.28 & -0.49 & 0.34 & -0.03 & $\ldots$ & $\ldots$ & 26 \\
\hline HE $1300+0157$ & -3.39 & 0.17 & $0.12 *$ & $\ldots$ & -0.53 & -0.86 & 0.39 & -0.02 & 0.13 & $\cdots$ & 40 \\
\hline HE $1300+0157$ & -3.53 & 0.46 & 0.64 & $<1.03$ & -0.11 & -0.46 & 0.76 & 0.26 & $\ldots$ & $<0.91$ & 36 \\
\hline HE $1300+0157$ & -3.76 & 0.26 & 0.34 & $\ldots$ & -0.37 & $\ldots$ & 0.50 & -0.04 & $\ldots$ & $\ldots$ & 26 \\
\hline HE $1300+0157$ & -3.46 & 0.29 & 0.49 & $<1.03$ & -0.34 & -0.66 & 0.55 & 0.07 & 0.13 & $<0.91$ & adopted \\
\hline HE 1300-0641 & -3.14 & -0.04 & -0.01 & $\ldots$ & -0.17 & -0.44 & 0.12 & 0.30 & $\ldots$ & $\ldots$ & 26 \\
\hline HE 1300-2201 & -2.61 & 0.19 & 0.38 & $\ldots$ & -0.11 & $\ldots$ & 0.39 & -0.07 & $\ldots$ & $\ldots$ & 26 \\
\hline
\end{tabular}


Table B.2. continued.

\begin{tabular}{|c|c|c|c|c|c|c|c|c|c|c|c|}
\hline Star & {$[\mathrm{Fe} / \mathrm{H}]$} & $\mathrm{Sc}$ & $\mathrm{Ti}$ & V & $\mathrm{Cr}$ & $\mathrm{Mn}$ & $\mathrm{Co}$ & $\mathrm{Ni}$ & $\mathrm{Cu}$ & $\mathrm{Zn}$ & Ref. \\
\hline HE $1305+0007$ & -2.03 & 0.09 & $0.79 *$ & $\ldots$ & & 0.14 & $\ldots$ & -0.25 & $\ldots$ & $\ldots$ & 30 \\
\hline HE 1305-0331 & -3.26 & 0.41 & 0.53 & $\ldots$ & -0.17 & $\ldots$ & $\ldots$ & -0.01 & $\ldots$ & $\ldots$ & 26 \\
\hline HE 1319-1935 & -1.74 & $\ldots$ & 0.10 & $\ldots$ & 0.75 & $\ldots$ & $\ldots$ & $\ldots$ & $\ldots$ & $\ldots$ & 37 \\
\hline HE $1327-2326$ & -5.66 & $\ldots$ & $0.52^{*}$ & $\ldots$ & $\ldots$ & $<1.14$ & $<2.08$ & $<0.59$ & $\ldots$ & $<3.07$ & 35 \\
\hline HE $1327-2326$ & -5.96 & $<1.11$ & $0.91 *$ & $<3.32$ & $<0.58$ & $<1.12$ & $<1.35$ & 0.18 & $\ldots$ & $<3.01$ & 39 \\
\hline HE $1327-2326$ & -5.96 & $<1.11$ & $0.91 *$ & $<3.32$ & $<0.58$ & $<1.12$ & $<1.35$ & 0.18 & $\begin{array}{l}\cdots \\
\ldots\end{array}$ & $<3.01$ & adopted \\
\hline HE 1330-0354 & -2.29 & 0.36 & 0.54 & $\ldots$ & -0.05 & -0.55 & $\ldots$ & -0.08 & $\ldots$ & $\ldots$ & 26 \\
\hline HE 1351-1049 & -3.46 & 0.28 & 0.30 & $\ldots$ & -0.28 & -0.63 & 0.48 & 0.30 & $\ldots$ & $\ldots$ & 26 \\
\hline HE 1410-0004 & -3.02 & $\ldots$ & 0.38 & $\ldots$ & -0.19 & -0.61 & $\ldots$ & $\ldots$ & $\ldots$ & $<0.90$ & 31 \\
\hline HE $1410+0213$ & -2.16 & $\ldots$ & 0.29 & $\ldots$ & -0.55 & $\ldots$ & $\ldots$ & $\ldots$ & $\ldots$ & $\ldots$ & 31 \\
\hline HE $1410+0213$ & -2.52 & $\ldots$ & & $\ldots$ & & $\ldots$ & $\ldots$ & $\ldots$ & $\ldots$ & $\ldots$ & 46 \\
\hline HE $1410+0213$ & -2.34 & $\ldots$ & 0.29 & $\ldots$ & -0.55 & $\ldots$ & $\ldots$ & $\ldots$ & $\ldots$ & $\ldots$ & adopted \\
\hline HE 1413-1954 & -3.22 & $\ldots$ & $\ldots$ & $\ldots$ & $\ldots$ & $\ldots$ & $\ldots$ & $\ldots$ & $\ldots$ & $\ldots$ & 26 \\
\hline HE 1419-1324 & -3.05 & $\ldots$ & $\ldots$ & $\ldots$ & $\ldots$ & $\ldots$ & $\ldots$ & $\ldots$ & $\ldots$ & $\ldots$ & 46 \\
\hline HE 1429-0551 & -2.47 & $\ldots$ & 0.23 & $\ldots$ & $\ldots$ & $\ldots$ & $\ldots$ & $\ldots$ & $\ldots$ & $\ldots$ & 37 \\
\hline HE $1430-1123$ & -2.71 & 0.37 & 0.25 & $\ldots$ & 0.00 & -0.57 & 0.39 & -0.21 & $\ldots$ & $\ldots$ & 26 \\
\hline HE $1434-1442$ & -2.39 & 0.18 & 0.31 & $\ldots$ & -0.30 & -0.40 & $<1.53$ & 0.76 & $\ldots$ & $\ldots$ & 31 \\
\hline HE $1443+0113$ & -2.07 & $\ldots$ & $\ldots$ & $\ldots$ & $\ldots$ & $\ldots$ & $\ldots$ & $\ldots$ & $\ldots$ & $\ldots$ & 31 \\
\hline HE $1447+0102$ & -2.47 & $\ldots$ & 0.46 & $\ldots$ & $\ldots$ & $\ldots$ & $\ldots$ & $\ldots$ & $\ldots$ & $\ldots$ & 37 \\
\hline HE 1509-0806 & -2.91 & $\ldots$ & 0.28 & $\ldots$ & -0.08 & -0.05 & 0.10 & $\ldots$ & $\ldots$ & $\ldots$ & 31 \\
\hline HE $1523-1155$ & -2.15 & $\ldots$ & 0.32 & $\ldots$ & $\ldots$ & $\ldots$ & $\ldots$ & $\ldots$ & $\ldots$ & $\ldots$ & 37 \\
\hline HE 1528-0409 & -2.61 & $\ldots$ & $\ldots$ & $\ldots$ & $\ldots$ & $\ldots$ & $\ldots$ & $\ldots$ & $\ldots$ & $\ldots$ & 37 \\
\hline HE 2148-1247 & -2.30 & 0.59 & 0.55 & $\ldots$ & -0.35 & -0.61 & 0.21 & 0.06 & $\ldots$ & $\ldots$ & 19 \\
\hline HE 2150-0825 & -1.98 & 0.22 & 0.31 & $\ldots$ & 0.07 & -0.37 & 0.02 & -0.27 & $\ldots$ & $\ldots$ & 26 \\
\hline HE 2158-0348 & -2.70 & $\ldots$ & 0.43 & $\ldots$ & -0.66 & -0.19 & -0.06 & $\ldots$ & $\ldots$ & $\ldots$ & 31 \\
\hline HE 2221-0453 & -2.22 & $\ldots$ & 0.54 & $\ldots$ & $\ldots$ & $\ldots$ & $\ldots$ & $\ldots$ & $\ldots$ & 0.49 & 37 \\
\hline HE 2228-0706 & -2.41 & $\ldots$ & 0.64 & $\ldots$ & 0.16 & $\ldots$ & $\ldots$ & $\ldots$ & $\ldots$ & 0.44 & 37 \\
\hline HE 2232-0603 & -1.85 & 0.05 & 0.35 & $\ldots$ & -0.06 & -0.41 & 0.02 & -0.65 & $\ldots$ & $\ldots$ & 31 \\
\hline HE 2240-0412 & -2.20 & 0.12 & 0.25 & $\ldots$ & -0.16 & -0.60 & 0.19 & -0.01 & $\ldots$ & $\ldots$ & 26 \\
\hline HE 2330-0555 & -2.78 & 0.25 & 0.31 & $\ldots$ & -0.10 & $\ldots$ & $\ldots$ & $\ldots$ & $\ldots$ & $\ldots$ & 37 \\
\hline LP 625-44 & -2.68 & 1.13 & 0.98 & $\cdots$ & -0.02 & -0.68 & -0.04 & 0.72 & $\cdots$ & & 3 \\
\hline LP 625-44 & -2.70 & $\ldots$ & $\ldots$ & $\ldots$ & $\ldots$ & $\ldots$ & $\ldots$ & $\ldots$ & $\ldots$ & $\ldots$ & 34 \\
\hline LP 625-44 & -2.71 & $\ldots$ & $\ldots$ & $\cdots$ & $\ldots$ & $\ldots$ & $\ldots$ & $\ldots$ & $\ldots$ & $\ldots$ & 4 \\
\hline LP 625-44 & -2.71 & & & 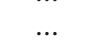 & & & $\ldots$ & & $\ldots$ & $\ldots$ & 9 \\
\hline LP $625-44$ & -2.70 & 1.13 & 0.98 & $\ldots$ & -0.02 & -0.68 & -0.04 & 0.72 & $\ldots$ & $\ldots$ & adopted \\
\hline SDSS 0036-10 & -2.42 & $\ldots$ & $0.51 *$ & $\ldots$ & -0.18 & $\ldots$ & 0.22 & -0.17 & $\ldots$ & $\ldots$ & 41 \\
\hline SDSS 0126+06 & -3.11 & $\ldots$ & $0.66^{*}$ & $\ldots$ & $\ldots$ & $\ldots$ & $\ldots$ & $\ldots$ & $\ldots$ & $\ldots$ & 41 \\
\hline SDSS 0817+26 & -3.16 & $\ldots$ & $\ldots$ & $\cdots$ & $\ldots$ & $\ldots$ & $\ldots$ & $\ldots$ & $\ldots$ & $\ldots$ & 41 \\
\hline SDSS 0912+02 & -2.5 & 0.28 & $0.51^{*}$ & $\cdots$ & -0.16 & -0.55 & 0.31 & 0.07 & $\ldots$ & $\ldots$ & 45 \\
\hline SDSS 0924+40 & -2.55 & 0.35 & $0.40^{*}$ & $\ldots$ & -0.29 & $\ldots$ & $\ldots$ & 0.05 & $\ldots$ & $\ldots$ & 41 \\
\hline SDSS $1036+12$ & -3.2 & 0.11 & $0.75^{*}$ & $\ldots$ & -0.12 & $\ldots$ & 0.57 & 0.28 & $\ldots$ & $\ldots$ & 45 \\
\hline SDSS 1349-02 & -3.0 & 0.01 & $0.55^{*}$ & $\ldots$ & -0.02 & -0.68 & 0.33 & 0.26 & $\ldots$ & $\ldots$ & 45 \\
\hline SDSS $1707+58$ & -2.49 & $\ldots$ & $0.60^{*}$ & $\ldots$ & $\ldots$ & $\ldots$ & $\ldots$ & $\ldots$ & $\ldots$ & $\ldots$ & 41 \\
\hline SDSS $2047+00$ & -2.05 & $\ldots$ & 0.80 & $\ldots$ & -0.10 & $\ldots$ & $\ldots$ & 0.08 & $\ldots$ & $\ldots$ & 41 \\
\hline
\end{tabular}

Notes. References are the same as in Table B.1. Ti abundances are of Ti I, and the symbol * indicates Ti II. See notes in Table B.1 for different IDs. 
D. M. Allen et al.: Elemental abundances and classification of CEMP stars

Table B.3. Abundances $[\mathrm{X} / \mathrm{Fe}]$ of heavy elements for CEMP stars.

\begin{tabular}{|c|c|c|c|c|c|c|c|c|c|c|c|c|c|c|c|c|c|c|c|c|}
\hline Star & {$[\mathrm{Fe} / \mathrm{H}]$} & $\mathrm{Ga}$ & $\mathrm{Ge}$ & $\mathrm{Sr}$ & $\mathrm{Y}$ & $\mathrm{Zr}$ & $\mathrm{Nb}$ & Mo & $\mathrm{Ru}$ & $\mathrm{Rh}$ & $\mathrm{Pd}$ & $\mathrm{Ag}$ & $\mathrm{Cd}$ & Sn & $\mathrm{Ba}$ & $\mathrm{La}$ & $\mathrm{Ce}$ & $\operatorname{Pr}$ & $\mathrm{Nd}$ & Ref. \\
\hline BS 16929-005 & -3.09 & $\ldots$ & $\ldots$ & 0.28 & 0.16 & $\ldots$ & $\ldots$ & $\ldots$ & $\ldots$ & $\ldots$ & $\ldots$ & $\ldots$ & $\ldots$ & $\ldots$ & -0.59 & $\cdots$ & $\ldots$ & $\ldots$ & $\ldots$ & 22 \\
\hline BS 16929-005 & -3.17 & $\ldots$ & $\ldots$ & $\ldots$ & $\ldots$ & $\ldots$ & $\ldots$ & $\ldots$ & $\ldots$ & $\ldots$ & $\ldots$ & $\ldots$ & $\ldots$ & $\ldots$ & -1.48 & $\ldots$ & $\ldots$ & $\ldots$ & $\ldots$ & 37 \\
\hline BS 16929-005 & -3.17 & $\ldots$ & $\ldots$ & 0.28 & 0.16 & $\ldots$ & $\ldots$ & $\ldots$ & $\ldots$ & $\ldots$ & $\ldots$ & $\ldots$ & $\ldots$ & $\ldots$ & -1.48 & $\ldots$ & $\ldots$ & $\ldots$ & $\ldots$ & adopted \\
\hline BS 17435-532 & -2.2 & $\ldots$ & $\ldots$ & 0.36 & 0.17 & 0.77 & $\ldots$ & $\ldots$ & $\ldots$ & $\ldots$ & $\ldots$ & $\ldots$ & $\ldots$ & $\ldots$ & 0.86 & 0.78 & 1.17 & 1.10 & 1.04 & 43 \\
\hline CS 22166-016 & -2.40 & $\ldots$ & $\ldots$ & -1.01 & $\ldots$ & $\ldots$ & $\ldots$ & $\ldots$ & $\ldots$ & $\ldots$ & $\ldots$ & $\ldots$ & $\ldots$ & $\ldots$ & -0.37 & $\ldots$ & $\ldots$ & $\ldots$ & $\ldots$ & 7 \\
\hline CS 22877-001 & -2.72 & $\ldots$ & $\ldots$ & -0.12 & 0.16 & $\ldots$ & $\ldots$ & $\ldots$ & $\ldots$ & $\ldots$ & $\ldots$ & $\ldots$ & $\ldots$ & $\ldots$ & -0.49 & $\ldots$ & $\ldots$ & $\ldots$ & $\ldots$ & 10 \\
\hline CS 22877-001 & -2.82 & $\ldots$ & $\ldots$ & -0.38 & -0.27 & $\ldots$ & $\ldots$ & $\ldots$ & $\ldots$ & $\ldots$ & $\ldots$ & $\ldots$ & $\ldots$ & $\ldots$ & -0.52 & $\ldots$ & $\ldots$ & $\ldots$ & $\ldots$ & 7 \\
\hline CS 22877-001 & -2.72 & $\ldots$ & $\ldots$ & -0.12 & 0.16 & $\ldots$ & $\ldots$ & $\ldots$ & $\ldots$ & $\ldots$ & $\ldots$ & $\ldots$ & $\ldots$ & $\ldots$ & -0.49 & $\ldots$ & $\ldots$ & $\ldots$ & $\ldots$ & adopted \\
\hline CS 22880-074 & -1.76 & $\ldots$ & $\ldots$ & 0.14 & 0.6 & 0.73 & $\ldots$ & $\ldots$ & $\ldots$ & $\ldots$ & $\ldots$ & $\ldots$ & $\ldots$ & $\ldots$ & 1.34 & 1.24 & $\ldots$ & $\ldots$ & $\ldots$ & 8 \\
\hline CS 22880-074 & -1.93 & $\ldots$ & $\ldots$ & 0.39 & 0.16 & $\ldots$ & $\ldots$ & $\ldots$ & $\ldots$ & $\ldots$ & $\ldots$ & $\ldots$ & $\ldots$ & $\ldots$ & 1.31 & 1.07 & 1.22 & $\ldots$ & 1.20 & 13 \\
\hline CS 22880-074 & -1.85 & $\ldots$ & $\ldots$ & 0.27 & 0.11 & 0.73 & $\ldots$ & $\ldots$ & $\ldots$ & $\ldots$ & $\ldots$ & $\ldots$ & $\ldots$ & $\ldots$ & 1.33 & 1.16 & 1.22 & $\ldots$ & 1.20 & adopted \\
\hline CS 22881-036 & -2.06 & $\ldots$ & $\ldots$ & 0.59 & 1.01 & 0.95 & $\ldots$ & $\ldots$ & $\ldots$ & $\ldots$ & $\ldots$ & $\ldots$ & $\ldots$ & $\ldots$ & 1.93 & 1.59 & $\ldots$ & $\ldots$ & 2.04 & 8 \\
\hline CS 22885-096 & -3.66 & $\ldots$ & $\ldots$ & -1.59 & $<0.54$ & $\ldots$ & $\ldots$ & $\ldots$ & $\ldots$ & $\ldots$ & $\ldots$ & $\ldots$ & $\ldots$ & $\ldots$ & -1.44 & $\ldots$ & $\ldots$ & $\ldots$ & $\ldots$ & 6 \\
\hline CS 22891-171 & -2.25 & $\ldots$ & $\ldots$ & $\ldots$ & $\ldots$ & $\ldots$ & $\ldots$ & $\ldots$ & $\ldots$ & $\ldots$ & $\ldots$ & $\ldots$ & $\ldots$ & $\ldots$ & 2.48 & 2.12 & 2.06 & $\ldots$ & $\ldots$ & 46 \\
\hline CS 22892-052 & -2.92 & $\ldots$ & $\ldots$ & 0.44 & 0.46 & 0.60 & $\ldots$ & $\ldots$ & 1.22 & $\ldots$ & $\ldots$ & $\ldots$ & $\ldots$ & $\ldots$ & 0.92 & 0.86 & 0.91 & 1.03 & 1.09 & 22 \\
\hline CS 22892-052 & -2.95 & $\ldots$ & $\ldots$ & 0.61 & 0.45 & $\ldots$ & $\ldots$ & $\ldots$ & $\ldots$ & $\ldots$ & $\ldots$ & $\ldots$ & $\ldots$ & $\ldots$ & 1.19 & 1.02 & . & $\ldots$ & 1.14 & 26 \\
\hline CS 22892-052 & -2.97 & $\ldots$ & $\ldots$ & 0.17 & 0.28 & 0.59 & $\ldots$ & $\ldots$ & $\ldots$ & $\ldots$ & $\ldots$ & $\ldots$ & $\ldots$ & $\ldots$ & 0.55 & 0.96 & 1.00 & $\ldots$ & 1.25 & 3 \\
\hline CS 22892-052 & -3.04 & $\ldots$ & $\ldots$ & 0.68 & 0.34 & 0.61 & $\ldots$ & $\ldots$ & $\ldots$ & $\ldots$ & $\ldots$ & $\ldots$ & $\ldots$ & $\ldots$ & 1.13 & 0.83 & 0.92 & $\ldots$ & 1.19 & 2 \\
\hline CS 22892-052 & -3.1 & $<0.2$ & $<-0.5$ & 0.58 & 0.44 & 0.73 & 0.88 & 0.78 & 1.34 & 1.43 & 1.12 & 0.98 & $<1.3$ & $<1.1$ & 0.99 & 1.09 & 1.02 & 1.30 & 1.33 & 18 \\
\hline CS 22892-052 & -3.00 & $<0.2$ & $<-0.5$ & 0.50 & 0.39 & 0.63 & 0.88 & 0.78 & 1.28 & 1.43 & 1.12 & 0.98 & $<1.3$ & $<1.1$ & 0.96 & 0.95 & 0.96 & 1.16 & 1.20 & adopted \\
\hline CS 22898-027 & -2.15 & $\ldots$ & $\ldots$ & 0.6 & 0.95 & 1.39 & $\ldots$ & $\ldots$ & $\ldots$ & $\ldots$ & $\ldots$ & $\ldots$ & $\ldots$ & $\ldots$ & 2.27 & 2.28 & 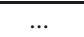 & $\ldots$ & 2.00 & 8 \\
\hline CS 22898-027 & -2.26 & $\ldots$ & $\ldots$ & 0.92 & 0.73 & 1.01 & $\ldots$ & $\ldots$ & $\ldots$ & $\ldots$ & $\ldots$ & $\ldots$ & $\ldots$ & $\ldots$ & 2.23 & 2.13 & 2.13 & $\ldots$ & 2.23 & 13 \\
\hline CS 22898-027 & -2.36 & $\ldots$ & $\ldots$ & 0.97 & $\ldots$ & $\ldots$ & $\ldots$ & $\ldots$ & $\ldots$ & $\ldots$ & $\ldots$ & $\ldots$ & $\ldots$ & $\ldots$ & 2.67 & 2.49 & 2.08 & $\ldots$ & 2.24 & 2 \\
\hline CS 22898-027 & -2.26 & $\ldots$ & $\ldots$ & 0.83 & 0.84 & 1.20 & $\ldots$ & $\ldots$ & $\ldots$ & $\ldots$ & $\ldots$ & $\ldots$ & $\ldots$ & $\ldots$ & 2.39 & 2.30 & 2.11 & $\ldots$ & 2.16 & adopted \\
\hline CS 22942-019 & -2.64 & $\ldots$ & $\ldots$ & 1.7 & 1.58 & 1.69 & $\ldots$ & $\ldots$ & $\ldots$ & $\ldots$ & $\ldots$ & $\ldots$ & $\ldots$ & $\ldots$ & 1.92 & 1.20 & 1.54 & $\ldots$ & 1.26 & 13 \\
\hline CS 22942-019 & -2.67 & $\ldots$ & $\ldots$ & 1.4 & $\ldots$ & $\ldots$ & $\ldots$ & $\ldots$ & $\ldots$ & $\ldots$ & $\ldots$ & $\ldots$ & $\ldots$ & $\ldots$ & 1.50 & 1.85 & $\ldots$ & $\ldots$ & $\ldots$ & 8 \\
\hline CS 22942-019 & -2.43 & $\ldots$ & $\ldots$ & $\ldots$ & $\ldots$ & $\ldots$ & $\ldots$ & $\ldots$ & $\ldots$ & $\ldots$ & $\ldots$ & $\ldots$ & $\ldots$ & $\ldots$ & 1.76 & 1.50 & 1.75 & $\ldots$ & $\ldots$ & 46 \\
\hline CS 22942-019 & -2.60 & $\ldots$ & $\ldots$ & 1.6 & 1.58 & 1.69 & $\ldots$ & $\ldots$ & $\ldots$ & $\ldots$ & $\ldots$ & $\ldots$ & $\ldots$ & $\ldots$ & 1.73 & 1.52 & 1.64 & $\ldots$ & 1.26 & adopted \\
\hline CS 22945-017 & -2.52 & $\ldots$ & $\ldots$ & $\ldots$ & $\ldots$ & $\ldots$ & $\ldots$ & $\ldots$ & $\ldots$ & $\ldots$ & $\ldots$ & $\ldots$ & $\ldots$ & $\ldots$ & 0.55 & 0.99 & $<1.24$ & $\ldots$ & $\ldots$ & 46 \\
\hline CS 22947-187 & -2.49 & $\ldots$ & $\ldots$ & 0.57 & 0.06 & 0.24 & $\ldots$ & $\ldots$ & $\ldots$ & $\ldots$ & $\ldots$ & $\ldots$ & $\ldots$ & $\ldots$ & 1.18 & 0.55 & 0.74 & $\ldots$ & 0.91 & 2 \\
\hline CS 22948-027 & -2.21 & $\ldots$ & $\ldots$ & $\ldots$ & $\ldots$ & $\ldots$ & $\ldots$ & $\ldots$ & $\ldots$ & $\ldots$ & $\ldots$ & $\ldots$ & $\ldots$ & $\ldots$ & 2.31 & $\ldots$ & $\ldots$ & $\ldots$ & $\ldots$ & 37 \\
\hline CS 22948-027 & -2.47 & $\ldots$ & $\ldots$ & 0.90 & 1.00 & $\ldots$ & $\ldots$ & $\ldots$ & $\ldots$ & $\ldots$ & $\ldots$ & $\ldots$ & $\ldots$ & $\ldots$ & 2.26 & 2.32 & 2.20 & 1.87 & 2.22 & 29 \\
\hline CS 22948-027 & -2.47 & $\ldots$ & $\ldots$ & 0.90 & 1.00 & $\ldots$ & $\ldots$ & $\ldots$ & $\ldots$ & $\ldots$ & $\ldots$ & $\ldots$ & $\ldots$ & $\ldots$ & 2.26 & 2.32 & 2.20 & 1.65 & 2.22 & 5 \\
\hline CS 22948-027 & -2.57 & $\ldots$ & $\ldots$ & $\ldots$ & $\ldots$ & $\ldots$ & $\ldots$ & $\ldots$ & $\ldots$ & $\ldots$ & $\ldots$ & $\ldots$ & $\ldots$ & $\ldots$ & 1.67 & $\ldots$ & $\ldots$ & $\ldots$ & $\ldots$ & 8 \\
\hline CS 22948-027 & -2.57 & $\ldots$ & $\ldots$ & $\ldots$ & 0.80 & $\ldots$ & $\ldots$ & $\ldots$ & $\ldots$ & $\ldots$ & $\ldots$ & $\ldots$ & $\ldots$ & $\ldots$ & 1.85 & 1.91 & 1.99 & 1.85 & 1.69 & 10 \\
\hline CS 22948-027 & -2.46 & $\ldots$ & $\ldots$ & 0.90 & 0.90 & $\ldots$ & $\ldots$ & $\ldots$ & $\ldots$ & $\ldots$ & $\ldots$ & $\ldots$ & $\ldots$ & $\ldots$ & 2.07 & 2.18 & 2.13 & 1.79 & 2.04 & adopted \\
\hline CS 22949-037 & $\begin{array}{l}-3.79 \\
\end{array}$ & $\ldots$ & $\ldots$ & 0.10 & 0.19 & $\ldots$ & $\ldots$ & $\ldots$ & $\ldots$ & $\ldots$ & $\ldots$ & $\ldots$ & $\ldots$ & $\ldots$ & $\begin{array}{c}-0.84 \\
\end{array}$ & $\ldots$ & $\ldots$ & 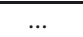 & $\ldots$ & 6 \\
\hline CS 22949-037 & -3.79 & $\ldots$ & $\ldots$ & $\ldots$ & $\ldots$ & $\ldots$ & $\ldots$ & $\ldots$ & $\ldots$ & $\ldots$ & $\ldots$ & $\ldots$ & $\ldots$ & $\ldots$ & $\ldots$ & $\ldots$ & $\ldots$ & $\ldots$ & $\ldots$ & 15 \\
\hline CS 22949-037 & -4.0 & $\ldots$ & $\ldots$ & 0.33 & -0.07 & $\ldots$ & $\ldots$ & $\ldots$ & $\ldots$ & $\ldots$ & $\ldots$ & $\ldots$ & $\ldots$ & $\ldots$ & -0.58 & $\ldots$ & $\ldots$ & $\ldots$ & $\ldots$ & 14 \\
\hline CS 22949-037 & -3.79 & $\ldots$ & $\ldots$ & 0.18 & $\ldots$ & $\ldots$ & $\ldots$ & $\ldots$ & $\ldots$ & $\ldots$ & $\ldots$ & $\ldots$ & $\ldots$ & $\ldots$ & -0.66 & $\ldots$ & $\ldots$ & $\ldots$ & $\ldots$ & 40 \\
\hline CS 22949-037 & -3.84 & $\ldots$ & $\ldots$ & 0.20 & 0.06 & $\ldots$ & $\ldots$ & $\ldots$ & $\ldots$ & $\ldots$ & $\ldots$ & $\ldots$ & $\ldots$ & $\ldots$ & -0.69 & $\ldots$ & $\ldots$ & $\ldots$ & $\ldots$ & adopted \\
\hline CS 22956-028 & -2.33 & $\ldots$ & $\ldots$ & $\ldots$ & $\ldots$ & $\ldots$ & $\ldots$ & $\ldots$ & $\ldots$ & $\ldots$ & $\ldots$ & $\ldots$ & $\ldots$ & $\ldots$ & 0.16 & $<0.50$ & 0.85 & $\ldots$ & $\ldots$ & 46 \\
\hline CS 22957-027 & -2.97 & $\ldots$ & $\ldots$ & -0.7 & $\ldots$ & $\ldots$ & $\ldots$ & $\ldots$ & $\ldots$ & $\ldots$ & $\ldots$ & $\ldots$ & $\ldots$ & $\ldots$ & -2.0 & $\ldots$ & $\ldots$ & $\ldots$ & $\ldots$ & 8 \\
\hline CS 22957-027 & -3.07 & $\ldots$ & $\ldots$ & -0.98 & $<-0.01$ & $\ldots$ & $\ldots$ & $\ldots$ & $\ldots$ & $\ldots$ & $\ldots$ & $\ldots$ & $\ldots$ & $\ldots$ & -0.78 & $<0.60$ & $<1.04$ & $<1.20$ & $\ldots$ & 31 \\
\hline CS 22957-027 & -3.12 & $\ldots$ & $\ldots$ & -0.56 & $\ldots$ & $\ldots$ & $\ldots$ & $\ldots$ & $\ldots$ & $\ldots$ & $\ldots$ & $\ldots$ & $\ldots$ & $\ldots$ & -1.23 & $\ldots$ & $\ldots$ & $\ldots$ & $\ldots$ & 11 \\
\hline CS 22957-027 & -3.12 & $\ldots$ & $\ldots$ & $\ldots$ & $\ldots$ & $\ldots$ & $\ldots$ & $\ldots$ & $\ldots$ & $\ldots$ & $\ldots$ & $\ldots$ & $\ldots$ & $\ldots$ & $\ldots$ & $\ldots$ & $\ldots$ & $\ldots$ & $\ldots$ & 12 \\
\hline CS 22957-027 & -3.07 & $\ldots$ & $\ldots$ & -0.75 & $<-0.01$ & $\ldots$ & $\ldots$ & $\ldots$ & $\ldots$ & $\ldots$ & $\ldots$ & $\ldots$ & $\ldots$ & $\ldots$ & -1.34 & $<0.60$ & $<1.04$ & $<1.20$ & $\ldots$ & adopted \\
\hline CS 22958-042 & -2.85 & $\ldots$ & $\ldots$ & -0.20 & $\ldots$ & $\ldots$ & $\ldots$ & $\ldots$ & $\ldots$ & $\ldots$ & $\ldots$ & $\ldots$ & $\ldots$ & $\ldots$ & $<-0.53$ & $\ldots$ & $\ldots$ & $\ldots$ & $\ldots$ & 33 \\
\hline CS 22960-053 & -3.14 & $\ldots$ & $\ldots$ & $\ldots$ & $\ldots$ & $\ldots$ & $\ldots$ & $\ldots$ & $\ldots$ & $\ldots$ & $\ldots$ & $\ldots$ & $\ldots$ & $\ldots$ & 0.86 & $\ldots$ & $\ldots$ & $\ldots$ & $\ldots$ & 37 \\
\hline CS 22964-161 & -2.43 & $\ldots$ & $\ldots$ & 0.52 & 0.29 & 0.69 & $\ldots$ & $\ldots$ & $\ldots$ & $\ldots$ & $\ldots$ & $\ldots$ & $\ldots$ & $\ldots$ & 1.26 & 1.07 & 1.29 & $\ldots$ & 1.01 & 42 \\
\hline CS 29497-030 & -2.57 & $<1.32$ & $\ldots$ & 1.34 & 0.97 & 1.40 & 1.67 & $\ldots$ & $\ldots$ & $\ldots$ & $\ldots$ & $<2.03$ & $\ldots$ & $\ldots$ & 2.32 & 2.22 & 2.10 & $\ldots$ & 2.14 & 27 \\
\hline CS 29497-030 & -2.77 & $\ldots$ & $\ldots$ & 0.84 & 0.71 & 1.43 & $\ldots$ & $\ldots$ & $\ldots$ & $\ldots$ & $\ldots$ & $\ldots$ & $\ldots$ & $\ldots$ & 2.17 & 2.10 & 2.14 & $\ldots$ & 1.85 & 21 \\
\hline CS 29497-030 & -2.67 & $<1.32$ & $\ldots$ & 1.09 & 0.84 & 1.42 & 1.67 & $\ldots$ & $\ldots$ & $\ldots$ & $\ldots$ & $<2.03$ & $\ldots$ & $\ldots$ & 2.25 & 2.16 & 2.12 & $\ldots$ & 2.00 & adopted \\
\hline CS 29497-034 & -2.90 & $\ldots$ & $\ldots$ & 1.00 & 1.10 & $\ldots$ & $\ldots$ & $\ldots$ & $\ldots$ & $\ldots$ & $\ldots$ & $\ldots$ & $\ldots$ & $\ldots$ & 2.03 & 2.12 & 1.95 & 1.82 & 2.09 & 29 \\
\hline CS 29497-034 & -2.91 & $\ldots$ & $\ldots$ & 1.00 & 1.10 & $\ldots$ & $\ldots$ & $\ldots$ & $\ldots$ & $\ldots$ & $\ldots$ & $\ldots$ & $\ldots$ & $\ldots$ & 2.03 & 2.12 & 1.95 & 1.65 & 2.09 & 5 \\
\hline CS 29497-034 & -2.91 & $\ldots$ & $\ldots$ & $\ldots$ & $\ldots$ & $\ldots$ & $\ldots$ & $\ldots$ & $\ldots$ & $\ldots$ & $\ldots$ & $\ldots$ & $\ldots$ & $\ldots$ & 2.23 & $\ldots$ & $\ldots$ & $\ldots$ & $\ldots$ & 37 \\
\hline CS 29497-034 & -2.90 & $\ldots$ & $\ldots$ & 1.00 & 1.10 & $\ldots$ & $\ldots$ & $\ldots$ & $\ldots$ & $\ldots$ & $\ldots$ & $\ldots$ & $\ldots$ & $\ldots$ & 2.13 & 2.12 & 1.95 & 1.82 & 2.09 & 29 \\
\hline CS 29498-043 & -3.54 & $\ldots$ & $\ldots$ & -0.47 & $\ldots$ & $\ldots$ & $\ldots$ & $\ldots$ & $\ldots$ & $\ldots$ & $\ldots$ & $\ldots$ & $\ldots$ & $\ldots$ & -0.46 & $\ldots$ & $\ldots$ & $\ldots$ & $\ldots$ & 25 \\
\hline CS 29498-043 & -3.75 & $\ldots$ & $\ldots$ & -0.35 & $\ldots$ & $\ldots$ & $\ldots$ & $\ldots$ & $\ldots$ & $\ldots$ & $\ldots$ & $\ldots$ & $\ldots$ & $\ldots$ & -0.45 & $\ldots$ & $\ldots$ & $\ldots$ & $\ldots$ & 11 \\
\hline CS 29498-043 & -3.75 & $\ldots$ & $\ldots$ & $\ldots$ & $\ldots$ & $\ldots$ & $\ldots$ & $\ldots$ & $\ldots$ & $\ldots$ & $\ldots$ & $\ldots$ & $\ldots$ & $\ldots$ & $\ldots$ & $\ldots$ & $\ldots$ & $\ldots$ & $\ldots$ & 12 \\
\hline CS 29498-043 & -3.54 & $\ldots$ & $\ldots$ & -0.47 & $\ldots$ & $\ldots$ & $\ldots$ & $\ldots$ & $\ldots$ & $\ldots$ & $\ldots$ & $\ldots$ & $\ldots$ & $\ldots$ & -0.46 & $\ldots$ & $\ldots$ & $\ldots$ & $\ldots$ & adopted \\
\hline 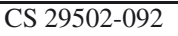 & -2.76 & $\ldots$ & $\ldots$ & -0.40 & -0.23 & $\ldots$ & $\ldots$ & $\ldots$ & $\ldots$ & $\ldots$ & $\ldots$ & $\ldots$ & $\ldots$ & $\ldots$ & -0.82 & $\ldots$ & $\ldots$ & $\ldots$ & $\ldots$ & 10 \\
\hline CS 29503-010 & -1.06 & $\ldots$ & $\ldots$ & $\ldots$ & $\ldots$ & $\ldots$ & $\ldots$ & $\ldots$ & $\ldots$ & $\ldots$ & $\ldots$ & $\ldots$ & $\ldots$ & $\ldots$ & 1.50 & $\ldots$ & $\ldots$ & $\ldots$ & $\ldots$ & 37 \\
\hline CS 29526-110 & -2.06 & $\ldots$ & $\ldots$ & 0.77 & 1.34 & 1.26 & $\ldots$ & $\ldots$ & $\ldots$ & $\ldots$ & $\ldots$ & $\ldots$ & $\ldots$ & $\ldots$ & 2.39 & 2.09 & $\ldots$ & $\ldots$ & $\ldots$ & 41 \\
\hline CS 29526-110 & -2.38 & $\ldots$ & $\ldots$ & 0.88 & $\ldots$ & 1.11 & $\ldots$ & $\ldots$ & $\ldots$ & $\ldots$ & $\ldots$ & $\ldots$ & $\ldots$ & $\ldots$ & 2.11 & 1.69 & 2.01 & $\ldots$ & 2.01 & 13 \\
\hline CS 29526-110 & -2.06 & $\ldots$ & $\ldots$ & 0.77 & 1.34 & 1.26 & $\ldots$ & $\ldots$ & $\ldots$ & $\ldots$ & $\ldots$ & $\ldots$ & $\ldots$ & $\ldots$ & 2.39 & 2.09 & 2.01 & $\ldots$ & 2.01 & adopted \\
\hline
\end{tabular}


Table B.3. continued.

\begin{tabular}{|c|c|c|c|c|c|c|c|c|c|c|c|c|c|c|c|c|c|c|c|c|}
\hline Star & {$[\mathrm{Fe} / \mathrm{H}]$} & $\mathrm{Ga}$ & $\mathrm{Ge}$ & $\mathrm{Sr}$ & $\mathrm{Y}$ & $\mathrm{Zr}$ & $\mathrm{Nb}$ & Mo & $\mathrm{Ru}$ & $\mathrm{Rh}$ & $\mathrm{Pd}$ & $\mathrm{Ag}$ & $\mathrm{Cd}$ & $\mathrm{Sn}$ & $\mathrm{Ba}$ & $\mathrm{La}$ & $\mathrm{Ce}$ & $\operatorname{Pr}$ & $\mathrm{Nd}$ & Ref. \\
\hline CS 29528-028 & -2.86 & $\ldots$ & $\ldots$ & $\ldots$ & $\ldots$ & $\ldots$ & $\ldots$ & $\ldots$ & $\ldots$ & $\ldots$ & $\ldots$ & $\ldots$ & $\ldots$ & $\ldots$ & 3.27 & $\ldots$ & $\ldots$ & $\ldots$ & $\ldots$ & 37 \\
\hline CS 29528-041 & -3.30 & $\ldots$ & $\ldots$ & -0.20 & $\ldots$ & $\ldots$ & $\ldots$ & $\ldots$ & $\ldots$ & $\ldots$ & $\ldots$ & $\ldots$ & $\ldots$ & $\ldots$ & 0.97 & $\ldots$ & $\ldots$ & $\ldots$ & $\ldots$ & 33 \\
\hline CS 30301-015 & -2.64 & $\ldots$ & $\ldots$ & 0.3 & 0.29 & $\ldots$ & $\ldots$ & $\ldots$ & $\ldots$ & $\ldots$ & $\ldots$ & $\ldots$ & $\ldots$ & $\ldots$ & 1.45 & 0.84 & 1.16 & $\ldots$ & 1.25 & 13 \\
\hline CS 30314-067 & -2.85 & $\ldots$ & $\ldots$ & -0.37 & -0.67 & 0.34 & $\ldots$ & $\ldots$ & $\ldots$ & $\ldots$ & $\ldots$ & $\ldots$ & $\ldots$ & $\ldots$ & -0.57 & $\ldots$ & $\ldots$ & $\ldots$ & $\ldots$ & 10 \\
\hline CS 30322-023 & -3.25 & $\ldots$ & $\ldots$ & $\ldots$ & $\ldots$ & $\ldots$ & $\ldots$ & $\ldots$ & $\ldots$ & $\ldots$ & $\ldots$ & $\ldots$ & $\ldots$ & $\ldots$ & 0.59 & $\ldots$ & $\ldots$ & $\ldots$ & $\ldots$ & 37 \\
\hline CS 30338-089 & -2.45 & $\ldots$ & $\ldots$ & $\ldots$ & $\ldots$ & $\ldots$ & $\ldots$ & $\ldots$ & $\ldots$ & $\ldots$ & $\ldots$ & $\ldots$ & $\ldots$ & $\ldots$ & 2.22 & $\ldots$ & $\ldots$ & $\ldots$ & $\ldots$ & 37 \\
\hline CS 31062-012 & -2.55 & $\ldots$ & $\ldots$ & 0.30 & 0.59 & $\ldots$ & $\ldots$ & $\ldots$ & $\ldots$ & $\ldots$ & $\ldots$ & $\ldots$ & $\ldots$ & $\ldots$ & 1.98 & 2.02 & 2.12 & $\ldots$ & 1.79 & 13 \\
\hline CS 31062-012 & -2.74 & $\ldots$ & $\ldots$ & 0.15 & 0.25 & $<1.16$ & $\ldots$ & $\ldots$ & $\ldots$ & $\ldots$ & $\ldots$ & $\ldots$ & $\ldots$ & $\ldots$ & 2.01 & 1.81 & 1.86 & $\ldots$ & 2.01 & 9 \\
\hline CS 31062-012 & -2.74 & $\ldots$ & $\ldots$ & 0.15 & 0.25 & $<1.16$ & $\ldots$ & $\ldots$ & $\ldots$ & $\ldots$ & $\ldots$ & $\ldots$ & $\ldots$ & $\ldots$ & 2.01 & 1.81 & 1.86 & $\ldots$ & 2.01 & 3 \\
\hline CS 31062-012 & -2.53 & $\ldots$ & $\ldots$ & 0.08 & $\ldots$ & $\ldots$ & $\ldots$ & $\ldots$ & $\ldots$ & $\ldots$ & $\ldots$ & $\ldots$ & $\ldots$ & $\ldots$ & 2.08 & 1.92 & $\ldots$ & $\ldots$ & $\ldots$ & 41 \\
\hline CS 31062-012 & -2.53 & $\ldots$ & $\ldots$ & 0.08 & 0.59 & $<1.16$ & $\ldots$ & $\ldots$ & $\ldots$ & $\ldots$ & $\ldots$ & $\ldots$ & $\ldots$ & $\ldots$ & 2.08 & 1.92 & 2.12 & $\ldots$ & 1.79 & adopted \\
\hline CS 31062-050 & -2.31 & $\ldots$ & $\ldots$ & 0.91 & $\ldots$ & 1.02 & $\ldots$ & $\ldots$ & $\ldots$ & $\ldots$ & $\ldots$ & $\ldots$ & $\ldots$ & $\ldots$ & 2.30 & 2.44 & 2.10 & $\ldots$ & 2.24 & 13 \\
\hline CS 31062-050 & -2.3 & $\ldots$ & $\ldots$ & $\ldots$ & $\ldots$ & $\ldots$ & $\ldots$ & $\ldots$ & $\ldots$ & $\ldots$ & $\ldots$ & $\ldots$ & $\ldots$ & $\ldots$ & 2.60 & 2.24 & $\ldots$ & $\ldots$ & $\ldots$ & 34 \\
\hline CS 31062-050 & -2.42 & $\ldots$ & $\ldots$ & $\ldots$ & 0.48 & 0.85 & $\ldots$ & $\ldots$ & $\ldots$ & $\ldots$ & 0.98 & $\ldots$ & $\ldots$ & $\ldots$ & 2.80 & 2.12 & 2.02 & 1.74 & 1.99 & 24 \\
\hline CS 31062-050 & -2.37 & $\ldots$ & $\ldots$ & 0.91 & 0.48 & 0.93 & $\ldots$ & $\ldots$ & $\ldots$ & $\ldots$ & 0.98 & $\ldots$ & $\ldots$ & $\ldots$ & 2.70 & 2.18 & 2.06 & 1.74 & 2.12 & adopted \\
\hline CS 31080-095 & -2.85 & $\ldots$ & $\ldots$ & -0.29 & -0.96 & $\ldots$ & $\ldots$ & $\ldots$ & $\ldots$ & $\ldots$ & $\ldots$ & $\ldots$ & $\ldots$ & $\ldots$ & 0.05 & $\ldots$ & $\ldots$ & $\ldots$ & $\ldots$ & 33 \\
\hline G77-61 & -4.03 & $\ldots$ & $\ldots$ & $<0$ & $\ldots$ & $\ldots$ & $\ldots$ & $\ldots$ & $\ldots$ & $\ldots$ & $\ldots$ & $\ldots$ & $\ldots$ & $\ldots$ & $<<1$ & $\ldots$ & $\ldots$ & $\ldots$ & $\ldots$ & 28 \\
\hline HD 5223 & -2.06 & $\ldots$ & $\ldots$ & 1.39 & 0.63 & 1.57 & $\ldots$ & $\ldots$ & $\ldots$ & $\ldots$ & $\ldots$ & $\ldots$ & $\ldots$ & $\ldots$ & 1.82 & 1.76 & 1.87 & $\ldots$ & 1.54 & 30 \\
\hline HD 187216 & -2.48 & $\ldots$ & $\ldots$ & $\ldots$ & 1.50 & 1.30 & 1.60 & 1.70 & 1.60 & $\ldots$ & $\ldots$ & $\ldots$ & $\ldots$ & $\ldots$ & 2.50 & 2.70 & 3.10 & 3.00 & 3.00 & 1 \\
\hline HD 187861 & -2.36 & $\ldots$ & $\ldots$ & $\ldots$ & $\ldots$ & $\ldots$ & $\ldots$ & $\ldots$ & $\ldots$ & $\ldots$ & $\ldots$ & $\ldots$ & $\ldots$ & $\ldots$ & 1.39 & 1.73 & 1.37 & $\ldots$ & $\ldots$ & 46 \\
\hline HD 196944 & -2.25 & $\ldots$ & $\ldots$ & 0.84 & 0.56 & 0.66 & $\ldots$ & $\ldots$ & $\ldots$ & $\ldots$ & $\ldots$ & $\ldots$ & $\ldots$ & $\ldots$ & 1.10 & 0.91 & 1.01 & $\ldots$ & 0.86 & 13 \\
\hline HD 196944 & -2.4 & $\ldots$ & $\ldots$ & $\ldots$ & $\ldots$ & 0.6 & $\ldots$ & $\ldots$ & $\ldots$ & $\ldots$ & $\ldots$ & $\ldots$ & $\ldots$ & $\ldots$ & $\ldots$ & 1.0 & 1.1 & $\ldots$ & 0.7 & 20 \\
\hline HD 196944 & -2.19 & $\ldots$ & $\ldots$ & $\ldots$ & $\ldots$ & $\ldots$ & $\ldots$ & $\ldots$ & $\ldots$ & $\ldots$ & $\ldots$ & $\ldots$ & $\ldots$ & $\ldots$ & 1.22 & 0.86 & 0.99 & $\ldots$ & $\ldots$ & 46 \\
\hline HD 196944 & -2.30 & $\ldots$ & $\ldots$ & 0.84 & 0.56 & 0.63 & $\ldots$ & $\ldots$ & $\ldots$ & $\ldots$ & $\ldots$ & $\ldots$ & $\ldots$ & $\ldots$ & 1.16 & 0.92 & 1.00 & $\ldots$ & 0.78 & adopted \\
\hline HD 209621 & -1.92 & $\ldots$ & $\ldots$ & 1.02 & 0.36 & 1.80 & $\ldots$ & $\ldots$ & $\ldots$ & $\ldots$ & $\ldots$ & $\ldots$ & $\ldots$ & $\ldots$ & 1.70 & 2.41 & 2.04 & 2.16 & 1.87 & 44 \\
\hline HD 224959 & -2.06 & $\ldots$ & $\ldots$ & $\ldots$ & $\ldots$ & $\ldots$ & $\ldots$ & $\ldots$ & $\ldots$ & $\ldots$ & $\ldots$ & $\ldots$ & $\ldots$ & $\ldots$ & 2.19 & 2.03 & 1.91 & $\ldots$ & $\ldots$ & 46 \\
\hline HE 0012-1441 & -2.52 & $\ldots$ & $\ldots$ & $\ldots$ & $\ldots$ & $\ldots$ & $\ldots$ & $\ldots$ & $\ldots$ & $\ldots$ & $\ldots$ & $\ldots$ & $\ldots$ & $\ldots$ & 1.15 & $\ldots$ & $\ldots$ & $\ldots$ & $\ldots$ & 31 \\
\hline HE 0024-2523 & -2.72 & $\ldots$ & $\ldots$ & 0.34 & $<0.91$ & $<1.22$ & $\ldots$ & $\ldots$ & $\ldots$ & $\ldots$ & $\ldots$ & $\ldots$ & $\ldots$ & $\ldots$ & 1.46 & 1.80 & $\ldots$ & $\ldots$ & $\ldots$ & 17 \\
\hline HE 0058-0244 & -2.75 & $\ldots$ & $\ldots$ & 0.34 & 0.52 & $\ldots$ & $\ldots$ & $\ldots$ & $\ldots$ & $\ldots$ & $\ldots$ & $\ldots$ & $\ldots$ & $\ldots$ & 2.04 & 1.70 & 1.88 & $\ldots$ & 1.91 & 31 \\
\hline HE 0107-5240 & -5.30 & $\ldots$ & $\ldots$ & $<-0.52$ & $\ldots$ & $\ldots$ & $\ldots$ & $\ldots$ & $\ldots$ & $\ldots$ & $\ldots$ & $\ldots$ & $\ldots$ & $\ldots$ & $<0.82$ & $\ldots$ & $\ldots$ & $\ldots$ & $\ldots$ & 23 \\
\hline HE $0107-5240$ & -5.30 & $\ldots$ & $\ldots$ & $<-0.5$ & $\ldots$ & $\ldots$ & $\ldots$ & $\ldots$ & $\ldots$ & $\ldots$ & $\ldots$ & $\ldots$ & $\ldots$ & $\ldots$ & $<0.8$ & $\ldots$ & $\ldots$ & $\ldots$ & $\ldots$ & 16 \\
\hline HE $0107-5240$ & -5.30 & $\ldots$ & $\ldots$ & $<-0.52$ & $\ldots$ & $\ldots$ & $\ldots$ & $\ldots$ & $\ldots$ & $\ldots$ & $\ldots$ & $\ldots$ & $\ldots$ & $\ldots$ & $<0.82$ & $\ldots$ & $\ldots$ & $\ldots$ & $\ldots$ & adopted \\
\hline HE 0131-3953 & -2.71 & $\ldots$ & $\ldots$ & 0.46 & $\ldots$ & $\ldots$ & $\ldots$ & $\ldots$ & $\ldots$ & $\ldots$ & $\ldots$ & $\ldots$ & $\ldots$ & $\ldots$ & 2.20 & 1.94 & 1.93 & $\ldots$ & 1.76 & 26 \\
\hline HE 0143-0441 & -2.31 & $\ldots$ & $\ldots$ & 0.86 & 0.59 & 1.05 & $\ldots$ & $\ldots$ & $\ldots$ & $\ldots$ & $\ldots$ & $\ldots$ & $\ldots$ & $\ldots$ & 2.32 & 1.78 & 1.93 & $\ldots$ & 2.17 & 31 \\
\hline HE 0202-2204 & -1.98 & $\ldots$ & $\ldots$ & 0.41 & 0.41 & 0.47 & $\ldots$ & $\ldots$ & $\ldots$ & $\ldots$ & $\ldots$ & $\ldots$ & $\ldots$ & $\ldots$ & 1.41 & 1.36 & 1.30 & $\ldots$ & 0.15 & 26 \\
\hline HE 0206-1916 & -2.09 & $\ldots$ & $\ldots$ & $\ldots$ & $\ldots$ & $\ldots$ & $\ldots$ & $\ldots$ & $\ldots$ & $\ldots$ & $\ldots$ & $\ldots$ & $\ldots$ & $\ldots$ & 1.97 & $\ldots$ & $\ldots$ & $\ldots$ & $\ldots$ & 37 \\
\hline HE 0212-0557 & -3.27 & $\ldots$ & $\ldots$ & -0.05 & 0.55 & $\ldots$ & $\ldots$ & $\ldots$ & $\ldots$ & $\ldots$ & $\ldots$ & $\ldots$ & $\ldots$ & $\ldots$ & 2.18 & 2.28 & 2.14 & 2.37 & 1.90 & 31 \\
\hline HE 0231-4016 & -2.08 & $\ldots$ & $\ldots$ & 0.67 & 0.72 & $\ldots$ & $\ldots$ & $\ldots$ & $\ldots$ & $\ldots$ & $\ldots$ & $\ldots$ & $\ldots$ & $\ldots$ & 1.47 & 1.22 & 1.53 & $\ldots$ & 1.35 & 26 \\
\hline HE $0336+0113$ & -2.68 & $\ldots$ & $\ldots$ & 1.68 & 1.40 & $\ldots$ & $\ldots$ & $\ldots$ & $\ldots$ & $\ldots$ & $\ldots$ & $\ldots$ & $\ldots$ & $\ldots$ & 2.63 & 1.93 & 2.30 & $\ldots$ & 2.12 & 31 \\
\hline HE 0338-3945 & -2.42 & $\ldots$ & $\ldots$ & 0.74 & 0.83 & 1.20 & $\ldots$ & $\ldots$ & $\ldots$ & $\ldots$ & $\ldots$ & $\ldots$ & $\ldots$ & $\ldots$ & 2.41 & 2.28 & $\ldots$ & $\ldots$ & 2.30 & 32 \\
\hline HE 0338-3945 & -2.41 & $\ldots$ & $\ldots$ & 0.73 & 0.73 & $\ldots$ & $\ldots$ & $\ldots$ & $\ldots$ & $\ldots$ & $\ldots$ & $\ldots$ & $\ldots$ & $\ldots$ & 2.41 & 2.26 & 2.21 & $\ldots$ & 2.09 & 26 \\
\hline HE 0338-3945 & -2.41 & $\ldots$ & $\ldots$ & 0.73 & 0.78 & 1.20 & $\ldots$ & $\ldots$ & $\ldots$ & $\ldots$ & $\ldots$ & $\ldots$ & $\ldots$ & $\ldots$ & 2.41 & 2.27 & 2.21 & $\ldots$ & 2.19 & adopted \\
\hline HE 0400-2030 & -1.73 & $\ldots$ & $\ldots$ & $\ldots$ & $\ldots$ & $\ldots$ & $\ldots$ & $\ldots$ & $\ldots$ & $\ldots$ & $\ldots$ & $\ldots$ & $\ldots$ & $\ldots$ & 1.64 & $\ldots$ & $\ldots$ & $\ldots$ & $\ldots$ & 37 \\
\hline HE 0430-4404 & -2.07 & $\ldots$ & $\ldots$ & 0.56 & 0.60 & $\ldots$ & $\ldots$ & $\ldots$ & $\ldots$ & $\ldots$ & $\ldots$ & $\ldots$ & $\ldots$ & $\ldots$ & 1.62 & 1.41 & $\ldots$ & $\ldots$ & $\ldots$ & 26 \\
\hline HE 0441-0652 & -2.47 & $\ldots$ & $\ldots$ & $\ldots$ & $\ldots$ & $\ldots$ & $\ldots$ & $\ldots$ & $\ldots$ & $\ldots$ & $\ldots$ & $\ldots$ & $\ldots$ & $\ldots$ & 1.11 & $\ldots$ & $\ldots$ & $\ldots$ & $\ldots$ & 37 \\
\hline HE 0507-1653 & -1.38 & $\ldots$ & $\ldots$ & $\ldots$ & $\ldots$ & $\ldots$ & $\ldots$ & $\ldots$ & $\ldots$ & $\ldots$ & $\ldots$ & $\ldots$ & $\ldots$ & $\ldots$ & 1.89 & $\ldots$ & $\ldots$ & $\ldots$ & $\ldots$ & 37 \\
\hline HE 0557-4840 & -4.75 & $\ldots$ & $\ldots$ & $<-1.07$ & $<0.74$ & $<2.27$ & $\ldots$ & $\ldots$ & $\ldots$ & $\ldots$ & $\ldots$ & $\ldots$ & $\ldots$ & $\ldots$ & $<0.03$ & $\ldots$ & $\ldots$ & $\ldots$ & $\ldots$ & 38 \\
\hline HE 1001-0243 & -2.88 & $\ldots$ & $\ldots$ & $\ldots$ & $\ldots$ & $\ldots$ & $\ldots$ & $\ldots$ & $\ldots$ & $\ldots$ & $\ldots$ & $\ldots$ & $\ldots$ & $\ldots$ & 0.41 & 0.55 & 0.80 & $\ldots$ & $\ldots$ & 46 \\
\hline HE 1005-1439 & -3.17 & $\ldots$ & $\ldots$ & $\ldots$ & $\ldots$ & $\ldots$ & $\ldots$ & $\ldots$ & $\ldots$ & $\ldots$ & $\ldots$ & $\ldots$ & $\ldots$ & $\ldots$ & 1.06 & $\ldots$ & $\ldots$ & $\ldots$ & $\ldots$ & 37 \\
\hline HE 1012-1540 & -3.43 & $\ldots$ & $\ldots$ & -0.54 & $\ldots$ & $\ldots$ & $\ldots$ & $\ldots$ & $\ldots$ & $\ldots$ & $\ldots$ & $\ldots$ & $\ldots$ & $\ldots$ & -0.29 & $\ldots$ & $\ldots$ & $\ldots$ & $\ldots$ & 40 \\
\hline HE 1031-0020 & -3.86 & $\ldots$ & $\ldots$ & 0.31 & 0.25 & $\ldots$ & $\ldots$ & $\ldots$ & $\ldots$ & $\ldots$ & $\ldots$ & $\ldots$ & $\ldots$ & $\ldots$ & 1.21 & 1.16 & 1.40 & $\ldots$ & 1.72 & 31 \\
\hline HE $1105+0027$ & -2.42 & $\ldots$ & $\ldots$ & 0.73 & 0.75 & $\ldots$ & $\ldots$ & $\ldots$ & $\ldots$ & $\ldots$ & $\ldots$ & $\ldots$ & $\ldots$ & $\ldots$ & 2.45 & 2.10 & $\ldots$ & $\ldots$ & 2.06 & 26 \\
\hline HE $1135+0139$ & -2.33 & $\ldots$ & $\ldots$ & 0.66 & 0.36 & 0.46 & $\ldots$ & $\ldots$ & $\ldots$ & $\ldots$ & $\ldots$ & $\ldots$ & $\ldots$ & $\ldots$ & 1.13 & 0.93 & 1.17 & $\ldots$ & 0.77 & 26 \\
\hline HE $1135-0344$ & -2.63 & $\ldots$ & $\ldots$ & 0.38 & $\ldots$ & $\ldots$ & $\ldots$ & $\ldots$ & $\ldots$ & $\ldots$ & $\ldots$ & $\ldots$ & $\ldots$ & $\ldots$ & $\ldots$ & $\ldots$ & $\ldots$ & $\ldots$ & $\ldots$ & 26 \\
\hline HE $1150-0428$ & -3.30 & $\ldots$ & $\ldots$ & -0.39 & $<0.23$ & $\ldots$ & $\ldots$ & $\ldots$ & $\ldots$ & $\ldots$ & $\ldots$ & $\ldots$ & $\ldots$ & $\ldots$ & -0.61 & $<1.16$ & $<2.04$ & $\ldots$ & $<1.59$ & 31 \\
\hline HE 1157-0518 & -2.34 & $\ldots$ & $\ldots$ & $\ldots$ & $\ldots$ & $\ldots$ & $\ldots$ & $\ldots$ & $\ldots$ & $\ldots$ & $\ldots$ & $\ldots$ & $\ldots$ & $\ldots$ & 2.14 & $\ldots$ & $\ldots$ & $\ldots$ & $\ldots$ & 37 \\
\hline HE 1221-1948 & -3.36 & $\ldots$ & $\ldots$ & $\ldots$ & $\ldots$ & $\ldots$ & $\ldots$ & $\ldots$ & $\ldots$ & $\ldots$ & $\ldots$ & $\ldots$ & $\ldots$ & $\ldots$ & $\ldots$ & $\ldots$ & $\ldots$ & $\ldots$ & $\ldots$ & 26 \\
\hline HE 1249-3121 & -3.23 & $\ldots$ & $\ldots$ & -0.98 & $\ldots$ & $\ldots$ & $\ldots$ & $\ldots$ & $\ldots$ & $\ldots$ & $\ldots$ & $\ldots$ & $\ldots$ & $\ldots$ & $\ldots$ & $\ldots$ & $\ldots$ & $\ldots$ & $\ldots$ & 26 \\
\hline HE $1300+0157$ & -3.39 & $\ldots$ & $\ldots$ & -1.55 & $\ldots$ & $\ldots$ & $\ldots$ & $\ldots$ & $\ldots$ & $\ldots$ & $\ldots$ & $\ldots$ & $\ldots$ & $\ldots$ & $<-0.63$ & $\ldots$ & $\ldots$ & $\ldots$ & $\ldots$ & 40 \\
\hline HE $1300+0157$ & -3.53 & $\ldots$ & $\ldots$ & $<-1.38$ & $<0.74$ & $<1.22$ & $\ldots$ & $\ldots$ & $\ldots$ & $\ldots$ & $\ldots$ & $\ldots$ & $\ldots$ & $\ldots$ & $<-0.70$ & $\ldots$ & $\ldots$ & $\ldots$ & $\ldots$ & 36 \\
\hline HE $1300+0157$ & -3.76 & $\ldots$ & $\ldots$ & $\ldots$ & 0.56 & $\ldots$ & $\ldots$ & $\ldots$ & $\ldots$ & $\ldots$ & $\ldots$ & $\ldots$ & $\ldots$ & $\ldots$ & $\ldots$ & $\ldots$ & $\ldots$ & $\ldots$ & $\ldots$ & 26 \\
\hline HE $1300+0157$ & -3.56 & $\ldots$ & $\ldots$ & -1.55 & 0.56 & $<1.22$ & $\ldots$ & $\ldots$ & $\ldots$ & $\ldots$ & $\ldots$ & $\ldots$ & $\ldots$ & $\ldots$ & $<-0.66$ & $\ldots$ & $\ldots$ & $\ldots$ & $\ldots$ & adopted \\
\hline HE 1300-0641 & -3.14 & $\ldots$ & $\ldots$ & -0.59 & $\ldots$ & $\ldots$ & $\ldots$ & $\ldots$ & $\ldots$ & $\ldots$ & $\ldots$ & $\ldots$ & $\ldots$ & $\ldots$ & -0.77 & $\ldots$ & $\ldots$ & $\ldots$ & $\ldots$ & 26 \\
\hline HE 1300-2201 & -2.61 & $\ldots$ & $\ldots$ & 0.28 & $\ldots$ & $\ldots$ & $\ldots$ & $\ldots$ & $\ldots$ & $\ldots$ & $\ldots$ & $\ldots$ & $\ldots$ & $\ldots$ & -0.04 & $\ldots$ & $\ldots$ & $\ldots$ & $\ldots$ & 26 \\
\hline HE $1305+0007$ & -2.03 & $\ldots$ & $\ldots$ & 0.86 & 0.73 & 2.09 & $\ldots$ & $\ldots$ & $\ldots$ & $\ldots$ & $\ldots$ & $\ldots$ & $\ldots$ & $\ldots$ & 2.32 & 2.56 & 2.53 & 2.38 & 2.59 & 30 \\
\hline
\end{tabular}


D. M. Allen et al.: Elemental abundances and classification of CEMP stars

Table B.3. continued.

\begin{tabular}{|c|c|c|c|c|c|c|c|c|c|c|c|c|c|c|c|c|c|c|c|c|}
\hline Star & {$[\mathrm{Fe} / \mathrm{H}]$} & $\mathrm{Ga}$ & $\mathrm{Ge}$ & $\mathrm{Sr}$ & $\mathrm{Y}$ & $\mathrm{Zr}$ & $\mathrm{Nb}$ & Mo & $\mathrm{Ru}$ & $\mathrm{Rh}$ & $\mathrm{Pd}$ & $\mathrm{Ag}$ & $\mathrm{Cd}$ & $\mathrm{Sn}$ & $\mathrm{Ba}$ & $\mathrm{La}$ & $\mathrm{Ce}$ & $\operatorname{Pr}$ & $\mathrm{Nd}$ & Ref. \\
\hline HE 1305-0331 & -3.26 & $\ldots$ & $\ldots$ & -0.17 & $\ldots$ & $\ldots$ & $\ldots$ & $\ldots$ & $\ldots$ & $\ldots$ & $\ldots$ & $\ldots$ & $\ldots$ & $\ldots$ & $\ldots$ & $\ldots$ & $\ldots$ & $\ldots$ & $\ldots$ & 26 \\
\hline HE 1319-1935 & -1.74 & $\ldots$ & $\ldots$ & $\ldots$ & $\ldots$ & $\ldots$ & $\ldots$ & $\ldots$ & $\ldots$ & $\ldots$ & $\ldots$ & $\ldots$ & $\ldots$ & $\ldots$ & 1.89 & $\ldots$ & $\ldots$ & $\ldots$ & $\ldots$ & 37 \\
\hline HE $1327-2326$ & -5.66 & $\ldots$ & $\ldots$ & 1.07 & $\ldots$ & $\ldots$ & $\ldots$ & $\ldots$ & $\ldots$ & $\ldots$ & $\ldots$ & $\ldots$ & $\ldots$ & $\ldots$ & $<1.46$ & $\ldots$ & $\ldots$ & $\ldots$ & $\ldots$ & 35 \\
\hline HE $1327-2326$ & -5.96 & $\ldots$ & $\ldots$ & 1.17 & $\ldots$ & $\ldots$ & $\ldots$ & $\ldots$ & $\ldots$ & $\ldots$ & $\ldots$ & $\ldots$ & $\ldots$ & $\ldots$ & $<1.40$ & $\ldots$ & $\ldots$ & $\ldots$ & $\ldots$ & 39 \\
\hline HE $1327-2326$ & -5.96 & $\ldots$ & $\ldots$ & 1.17 & $\ldots$ & $\ldots$ & $\ldots$ & $\ldots$ & $\ldots$ & $\ldots$ & $\ldots$ & $\ldots$ & $\ldots$ & $\ldots$ & $<1.40$ & $\ldots$ & $\ldots$ & $\ldots$ & $\ldots$ & adopted \\
\hline HE 1330-0354 & -2.29 & $\ldots$ & $\ldots$ & 0.01 & $\ldots$ & $\ldots$ & $\ldots$ & $\ldots$ & $\ldots$ & $\ldots$ & $\ldots$ & $\ldots$ & $\ldots$ & $\ldots$ & -0.47 & $\ldots$ & $\ldots$ & $\ldots$ & $\ldots$ & 26 \\
\hline HE 1351-1049 & -3.46 & $\ldots$ & $\ldots$ & 0.03 & $\ldots$ & $\ldots$ & $\ldots$ & $\ldots$ & $\ldots$ & $\ldots$ & $\ldots$ & $\ldots$ & $\ldots$ & $\ldots$ & 0.13 & $\ldots$ & $\ldots$ & $\ldots$ & $\ldots$ & 26 \\
\hline HE 1410-0004 & -3.02 & $\ldots$ & $\ldots$ & 0.18 & $\ldots$ & $\ldots$ & $\ldots$ & $\ldots$ & $\ldots$ & $\ldots$ & $\ldots$ & $\ldots$ & $\ldots$ & $\ldots$ & 1.06 & $\ldots$ & $\ldots$ & $\ldots$ & $\ldots$ & 31 \\
\hline HE $1410+0213$ & -2.16 & $\ldots$ & $\ldots$ & $\ldots$ & $\ldots$ & $\ldots$ & $\ldots$ & $\ldots$ & $\ldots$ & $\ldots$ & $\ldots$ & $\ldots$ & $\ldots$ & $\ldots$ & 0.07 & $\ldots$ & $\ldots$ & $\ldots$ & $\ldots$ & 31 \\
\hline HE $1410+0213$ & -2.52 & $\ldots$ & $\ldots$ & $\ldots$ & $\ldots$ & $\ldots$ & $\ldots$ & $\ldots$ & $\ldots$ & $\ldots$ & $\ldots$ & $\ldots$ & $\ldots$ & $\ldots$ & 0.05 & -0.41 & 0.14 & $\ldots$ & $\ldots$ & 46 \\
\hline HE $1410+0213$ & -2.34 & $\ldots$ & $\ldots$ & $\ldots$ & $\ldots$ & $\ldots$ & $\ldots$ & $\ldots$ & $\ldots$ & $\ldots$ & $\ldots$ & $\ldots$ & $\ldots$ & $\ldots$ & 0.06 & -0.41 & 0.14 & $\ldots$ & $\ldots$ & adopted \\
\hline HE 1413-1954 & -3.22 & $\ldots$ & $\ldots$ & -0.47 & $\ldots$ & $\ldots$ & $\ldots$ & $\ldots$ & $\ldots$ & $\ldots$ & $\ldots$ & $\ldots$ & $\ldots$ & $\ldots$ & $\ldots$ & $\ldots$ & $\ldots$ & $\ldots$ & $\ldots$ & 26 \\
\hline HE 1419-1324 & -3.05 & $\ldots$ & $\ldots$ & $\ldots$ & $\ldots$ & $\ldots$ & $\ldots$ & $\ldots$ & $\ldots$ & $\ldots$ & $\ldots$ & $\ldots$ & $\ldots$ & $\ldots$ & 0.88 & 0.82 & 0.83 & $\ldots$ & $\ldots$ & 46 \\
\hline HE 1429-0551 & -2.47 & $\ldots$ & $\ldots$ & $\ldots$ & $\ldots$ & $\ldots$ & $\ldots$ & $\ldots$ & $\ldots$ & $\ldots$ & $\ldots$ & $\ldots$ & $\ldots$ & $\ldots$ & 1.57 & $\ldots$ & $\ldots$ & $\ldots$ & $\ldots$ & 37 \\
\hline HE 1430-1123 & -2.71 & $\ldots$ & $\ldots$ & 0.24 & 0.50 & $\ldots$ & $\ldots$ & $\ldots$ & $\ldots$ & $\ldots$ & $\ldots$ & $\ldots$ & $\ldots$ & $\ldots$ & 1.82 & $\ldots$ & $\ldots$ & $\ldots$ & 1.72 & 26 \\
\hline HE 1434-1442 & -2.39 & $\ldots$ & $\ldots$ & $\ldots$ & 0.37 & $\ldots$ & $\ldots$ & $\ldots$ & $\ldots$ & $\ldots$ & $\ldots$ & $\ldots$ & $\ldots$ & $\ldots$ & 1.23 & $\ldots$ & $\ldots$ & $\ldots$ & 1.70 & 31 \\
\hline HE $1443+0113$ & -2.07 & $\ldots$ & $\ldots$ & $\ldots$ & $\ldots$ & $\ldots$ & $\ldots$ & $\ldots$ & $\ldots$ & $\ldots$ & $\ldots$ & $\ldots$ & $\ldots$ & $\ldots$ & 1.40 & $\ldots$ & $\ldots$ & $\ldots$ & $\ldots$ & 31 \\
\hline HE $1447+0102$ & -2.47 & $\ldots$ & $\ldots$ & $\ldots$ & $\ldots$ & $\ldots$ & $\ldots$ & $\ldots$ & $\ldots$ & $\ldots$ & $\ldots$ & $\ldots$ & $\ldots$ & $\ldots$ & 2.70 & $\ldots$ & $\ldots$ & $\ldots$ & $\ldots$ & 37 \\
\hline HE 1509-0806 & -2.91 & $\ldots$ & $\ldots$ & 1.12 & 0.95 & $\ldots$ & $\ldots$ & $\ldots$ & $\ldots$ & $\ldots$ & $\ldots$ & $\ldots$ & $\ldots$ & $\ldots$ & 1.93 & 1.67 & 1.89 & $\ldots$ & 2.18 & 31 \\
\hline HE 1523-1155 & -2.15 & $\ldots$ & $\ldots$ & $\ldots$ & $\ldots$ & $\ldots$ & $\ldots$ & $\ldots$ & $\ldots$ & $\ldots$ & $\ldots$ & $\ldots$ & $\ldots$ & $\ldots$ & 1.72 & $\ldots$ & $\ldots$ & $\ldots$ & $\ldots$ & 37 \\
\hline HE 1528-0409 & -2.61 & $\ldots$ & $\ldots$ & $\ldots$ & $\ldots$ & $\ldots$ & $\ldots$ & $\ldots$ & $\ldots$ & $\ldots$ & $\ldots$ & $\ldots$ & $\ldots$ & $\ldots$ & 2.30 & $\ldots$ & $\ldots$ & $\ldots$ & $\ldots$ & 37 \\
\hline HE 2148-1247 & -2.30 & $\ldots$ & $\ldots$ & 0.76 & 0.83 & 1.47 & $\ldots$ & $\ldots$ & $\ldots$ & $\ldots$ & $\ldots$ & $\ldots$ & $\ldots$ & $\ldots$ & 2.36 & 2.38 & 2.28 & 2.52 & 2.27 & 19 \\
\hline HE 2150-0825 & -1.98 & $\ldots$ & $\ldots$ & 0.66 & 0.85 & 0.97 & $\ldots$ & $\ldots$ & $\ldots$ & $\ldots$ & $\ldots$ & $\ldots$ & $\ldots$ & $\ldots$ & 1.70 & 1.41 & 1.48 & $\ldots$ & 1.42 & 26 \\
\hline HE 2158-0348 & -2.70 & $\ldots$ & $\ldots$ & 0.52 & 0.87 & 1.74 & $\ldots$ & $\ldots$ & $\ldots$ & $\ldots$ & $\ldots$ & $\ldots$ & $\ldots$ & $\ldots$ & 1.59 & 1.55 & 1.89 & $\ldots$ & 1.51 & 31 \\
\hline HE 2221-0453 & -2.22 & $\ldots$ & $\ldots$ & $\ldots$ & $\ldots$ & $\ldots$ & $\ldots$ & $\ldots$ & $\ldots$ & $\ldots$ & $\ldots$ & $\ldots$ & $\ldots$ & $\ldots$ & 1.75 & $\ldots$ & $\ldots$ & $\ldots$ & $\ldots$ & 37 \\
\hline HE 2228-0706 & -2.41 & $\ldots$ & $\ldots$ & $\ldots$ & $\ldots$ & $\ldots$ & $\ldots$ & $\ldots$ & $\ldots$ & $\ldots$ & $\ldots$ & $\ldots$ & $\ldots$ & $\ldots$ & 2.50 & $\ldots$ & $\ldots$ & $\ldots$ & $\ldots$ & 37 \\
\hline HE 2232-0603 & -1.85 & $\ldots$ & $\ldots$ & 0.55 & 0.60 & $\ldots$ & $\ldots$ & $\ldots$ & $\ldots$ & $\ldots$ & $\ldots$ & $\ldots$ & $\ldots$ & $\ldots$ & 1.41 & 1.23 & 1.45 & $\ldots$ & $\ldots$ & 31 \\
\hline HE 2240-0412 & -2.20 & $\ldots$ & $\ldots$ & 0.24 & $\ldots$ & $\ldots$ & $\ldots$ & $\ldots$ & $\ldots$ & $\ldots$ & $\ldots$ & $\ldots$ & $\ldots$ & $\ldots$ & 1.37 & $\ldots$ & $\ldots$ & $\ldots$ & $\ldots$ & 26 \\
\hline HE 2330-0555 & -2.78 & $\ldots$ & $\ldots$ & $\ldots$ & $\ldots$ & $\ldots$ & $\ldots$ & $\ldots$ & $\ldots$ & $\ldots$ & $\ldots$ & $\ldots$ & $\ldots$ & $\ldots$ & 1.22 & $\ldots$ & $\ldots$ & $\ldots$ & $\ldots$ & 37 \\
\hline LP 625-44 & -2.68 & $\ldots$ & $\ldots$ & 0.73 & 1.38 & 1.62 & $\ldots$ & $\ldots$ & $\ldots$ & $\ldots$ & $\ldots$ & $\ldots$ & $\ldots$ & $\ldots$ & 2.57 & 2.56 & 2.70 & $\ldots$ & 2.61 & 3 \\
\hline LP 625-44 & -2.70 & $\ldots$ & $\ldots$ & $\ldots$ & $\ldots$ & $\ldots$ & $\ldots$ & $\ldots$ & $\ldots$ & $\ldots$ & $\ldots$ & $\ldots$ & $\ldots$ & $\ldots$ & 2.86 & 2.50 & $\ldots$ & $\ldots$ & $\ldots$ & 34 \\
\hline LP 625-44 & -2.71 & $\ldots$ & $\ldots$ & 1.15 & 0.92 & 1.31 & $\ldots$ & $\ldots$ & $\ldots$ & $\ldots$ & $\ldots$ & $\ldots$ & $\ldots$ & $\ldots$ & 2.74 & 2.50 & 2.27 & 2.45 & 2.22 & 4 \\
\hline LP 625-44 & -2.71 & $\ldots$ & $\ldots$ & 1.15 & 0.99 & 1.34 & $\ldots$ & $\ldots$ & $\ldots$ & $\ldots$ & $\ldots$ & $\ldots$ & $\ldots$ & $\ldots$ & 2.74 & 2.46 & 2.27 & 2.45 & 2.30 & 9 \\
\hline LP 625-44 & -2.70 & $\ldots$ & $\ldots$ & 1.15 & 0.99 & 1.34 & $\ldots$ & $\ldots$ & $\ldots$ & $\ldots$ & $\ldots$ & $\ldots$ & $\ldots$ & $\ldots$ & 2.86 & 2.50 & 2.27 & 2.45 & 2.22 & adopted \\
\hline SDSS 0036-10 & -2.42 & $\ldots$ & $\ldots$ & -0.27 & $\ldots$ & $\ldots$ & $\ldots$ & $\ldots$ & $\ldots$ & $\ldots$ & $\ldots$ & $\ldots$ & $\ldots$ & $\ldots$ & 0.29 & $\ldots$ & $\ldots$ & $\ldots$ & $\ldots$ & 41 \\
\hline SDSS 0126+06 & -3.11 & $\ldots$ & $\ldots$ & 1.35 & $\ldots$ & 1.93 & $\ldots$ & $\ldots$ & $\ldots$ & $\ldots$ & $\ldots$ & $\ldots$ & $\ldots$ & $\ldots$ & 2.75 & 2.46 & $\ldots$ & $\ldots$ & $\ldots$ & 41 \\
\hline SDSS $0817+26$ & -3.16 & $\ldots$ & $\ldots$ & 0.14 & $\ldots$ & $\ldots$ & $\ldots$ & $\ldots$ & $\ldots$ & $\ldots$ & $\ldots$ & $\ldots$ & $\ldots$ & $\ldots$ & 0.77 & $\ldots$ & $\ldots$ & $\ldots$ & $\ldots$ & 41 \\
\hline SDSS 0912+02 & -2.5 & $\ldots$ & $\ldots$ & 0.57 & 0.61 & 1.08 & $\ldots$ & $\ldots$ & 2.61 & $\ldots$ & $\ldots$ & $\ldots$ & $\ldots$ & $\ldots$ & 1.49 & 1.35 & 2.17 & 2.25 & 1.12 & 45 \\
\hline SDSS 0924+40 & -2.55 & $\ldots$ & $\ldots$ & 0.60 & $\ldots$ & $\ldots$ & $\ldots$ & $\ldots$ & $\ldots$ & $\ldots$ & $\ldots$ & $\ldots$ & $\ldots$ & $\ldots$ & 1.81 & $\ldots$ & $\ldots$ & $\ldots$ & $\ldots$ & 41 \\
\hline SDSS $1036+12$ & -3.2 & $\ldots$ & $\ldots$ & -0.56 & 0.24 & 1.02 & $\ldots$ & $\ldots$ & $\ldots$ & $\ldots$ & 2.40 & $\ldots$ & $\ldots$ & $\ldots$ & 1.17 & 2.39 & 2.32 & 2.45 & 2.08 & 45 \\
\hline SDSS 1349-02 & -3.0 & $\ldots$ & $\ldots$ & 1.30 & 1.29 & 1.56 & $\ldots$ & $\ldots$ & $\ldots$ & $\ldots$ & $\ldots$ & $\ldots$ & $\ldots$ & $\ldots$ & 2.17 & 1.74 & 2.63 & 2.87 & 1.91 & 45 \\
\hline SDSS $1707+58$ & -2.49 & $\ldots$ & $\ldots$ & 2.25 & $\ldots$ & $\ldots$ & $\ldots$ & $\ldots$ & $\ldots$ & $\ldots$ & $\ldots$ & $\ldots$ & $\ldots$ & $\ldots$ & 3.40 & $\ldots$ & $\ldots$ & $\ldots$ & $\ldots$ & 41 \\
\hline SDSS $2047+00$ & -2.05 & $\ldots$ & $\ldots$ & 0.68 & 0.79 & 0.96 & $\ldots$ & $\ldots$ & $\ldots$ & $\ldots$ & $\ldots$ & $\ldots$ & $\ldots$ & $\ldots$ & 0.24 & $\ldots$ & $\ldots$ & $\ldots$ & $\ldots$ & 41 \\
\hline
\end{tabular}

Notes. References are the same as in Table B.1. See notes in Table B.1 for different IDs. 
Table B.4. Abundances $[\mathrm{X} / \mathrm{Fe}]$ of heavy elements for CEMP stars.

\begin{tabular}{|c|c|c|c|c|c|c|c|c|c|c|c|c|c|c|c|c|c|c|c|c|c|c|}
\hline Star & {$[\mathrm{Fe} / \mathrm{H}]$} & $\mathrm{Sm}$ & $\mathrm{Eu}$ & $\mathrm{Gd}$ & $\mathrm{Tb}$ & Dy & Ho & Er & $\mathrm{Tm}$ & $\mathrm{Yb}$ & $\mathrm{Lu}$ & $\mathrm{Hf}$ & W & Os & Ir & $\mathrm{Pt}$ & $\mathrm{Au}$ & $\mathrm{Pb}$ & $\mathrm{Bi}$ & Th & $\mathrm{U}$ & Ref. \\
\hline BS 16929-005 & -3.09 & $\ldots$ & $\ldots$ & $\ldots$ & $\ldots$ & $\ldots$ & $\ldots$ & $\ldots$ & $\ldots$ & $\ldots$ & $\cdots$ & $\ldots$ & $\ldots$ & $\ldots$ & $\ldots$ & $\ldots$ & $\ldots$ & $\ldots$ & $\ldots$ & $\ldots$ & $\ldots$ & 22 \\
\hline BS 16929-005 & -3.17 & $\ldots$ & $\ldots$ & $\ldots$ & $\ldots$ & $\ldots$ & $\ldots$ & $\ldots$ & $\ldots$ & $\ldots$ & $\ldots$ & $\ldots$ & $\ldots$ & $\ldots$ & $\ldots$ & $\ldots$ & $\ldots$ & $\ldots$ & $\ldots$ & $\ldots$ & $\ldots$ & 37 \\
\hline BS 16929-005 & -3.17 & $\ldots$ & $\ldots$ & $\ldots$ & $\ldots$ & $\ldots$ & $\ldots$ & $\ldots$ & $\ldots$ & $\ldots$ & $\ldots$ & $\ldots$ & $\ldots$ & $\ldots$ & $\ldots$ & $\ldots$ & $\ldots$ & $\ldots$ & $\ldots$ & $\ldots$ & $\ldots$ & adopted \\
\hline BS 17435-532 & -2.2 & 0.73 & 0.48 & $\ldots$ & $\ldots$ & $\ldots$ & $\ldots$ & $\ldots$ & $\ldots$ & $\ldots$ & $\ldots$ & $\ldots$ & $\ldots$ & $\ldots$ & $\ldots$ & $\ldots$ & $\ldots$ & $\ldots$ & $\ldots$ & $\ldots$ & $\ldots$ & 43 \\
\hline CS 22166-016 & -2.40 & $\ldots$ & $\ldots$ & $\ldots$ & $\ldots$ & $\ldots$ & $\ldots$ & $\ldots$ & $\ldots$ & $\ldots$ & $\ldots$ & $\ldots$ & $\ldots$ & $\ldots$ & $\ldots$ & $\ldots$ & $\ldots$ & $\ldots$ & $\ldots$ & $\ldots$ & $\ldots$ & 7 \\
\hline$\overline{C S} 22877-001$ & -2.72 & $\ldots$ & $<0.6$ & $\ldots$ & $\ldots$ & $\ldots$ & $\ldots$ & $\ldots$ & $\ldots$ & $\ldots$ & $\ldots$ & $\ldots$ & $\ldots$ & $\ldots$ & $\ldots$ & $\ldots$ & $\ldots$ & $\ldots$ & $\ldots$ & $\ldots$ & $\ldots$ & 10 \\
\hline CS 22877-001 & -2.82 & $\ldots$ & $\ldots$ & $\ldots$ & $\ldots$ & $\ldots$ & $\ldots$ & $\ldots$ & $\ldots$ & $\ldots$ & $\ldots$ & $\ldots$ & $\ldots$ & $\ldots$ & $\ldots$ & $\ldots$ & $\ldots$ & $\ldots$ & $\ldots$ & $\ldots$ & $\ldots$ & 7 \\
\hline CS 22877-001 & -2.72 & $\ldots$ & $<0.6$ & $\ldots$ & $\ldots$ & $\ldots$ & $\ldots$ & $\ldots$ & $\ldots$ & $\ldots$ & $\ldots$ & $\ldots$ & $\ldots$ & $\ldots$ & $\ldots$ & $\ldots$ & $\ldots$ & $\ldots$ & $\ldots$ & $\ldots$ & $\ldots$ & adopted \\
\hline CS 22880-074 & -1.76 & $\ldots$ & 0.55 & $\ldots$ & $\ldots$ & & $\ldots$ & $\ldots$ & $\ldots$ & $\ldots$ & $\ldots$ & $\ldots$ & $\ldots$ & $\ldots$ & $\ldots$ & $\ldots$ & $\ldots$ & 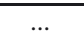 & $\ldots$ & $\ldots$ & $\ldots$ & 8 \\
\hline CS 22880-074 & -1.93 & $\ldots$ & 0.5 & $\ldots$ & $\ldots$ & 0.60 & $\ldots$ & 1.41 & $\ldots$ & $\ldots$ & $\ldots$ & $\ldots$ & $\ldots$ & $\ldots$ & $\ldots$ & $\ldots$ & $\ldots$ & 1.9 & $\ldots$ & $\ldots$ & $\ldots$ & 13 \\
\hline CS 22880-074 & -1.85 & $\ldots$ & 0.53 & $\ldots$ & $\ldots$ & 0.60 & $\ldots$ & 1.41 & $\ldots$ & $\ldots$ & $\ldots$ & $\ldots$ & $\ldots$ & $\ldots$ & $\ldots$ & $\ldots$ & $\ldots$ & 1.9 & $\ldots$ & $\ldots$ & $\ldots$ & adopted \\
\hline CS 22881-036 & -2.06 & $\ldots$ & 1.00 & $\ldots$ & $\ldots$ & $\ldots$ & $\ldots$ & $\ldots$ & $\ldots$ & $\ldots$ & $\ldots$ & $\ldots$ & $\ldots$ & $\ldots$ & $\ldots$ & $\ldots$ & $\ldots$ & $\ldots$ & $\ldots$ & $\ldots$ & $\ldots$ & 8 \\
\hline CS 22885-096 & -3.66 & $\ldots$ & $<0.68$ & $\ldots$ & $\ldots$ & $\ldots$ & $\ldots$ & $\ldots$ & $\ldots$ & $\ldots$ & $\ldots$ & $\ldots$ & $\ldots$ & $\ldots$ & $\ldots$ & $\ldots$ & $\ldots$ & $\ldots$ & $\ldots$ & $\ldots$ & $\ldots$ & 6 \\
\hline CS 22891-171 & -2.25 & 1.73 & $\ldots$ & $\ldots$ & $\ldots$ & $\ldots$ & $\ldots$ & $\ldots$ & $\ldots$ & $\ldots$ & $\ldots$ & $\ldots$ & $\ldots$ & $\ldots$ & $\ldots$ & $\ldots$ & $\ldots$ & 1.85 & $\ldots$ & $\ldots$ & $\ldots$ & 46 \\
\hline CS 22892-052 & -2.92 & 1.29 & 1.51 & 1.43 & 1.26 & 1.54 & $\ldots$ & 1.501 & 1.36 & 1.29 & $\ldots$ & $\ldots$ & $\ldots$ & $\ldots$ & $\ldots$ & $\ldots$ & $\ldots$ & $\ldots$ & $\ldots$ & 1.41 & $<1.50$ & 22 \\
\hline 2892-052 & -2.95 & $\ldots$ & 1.54 & $\ldots$ & $\ldots$ & & $\ldots$ & $\ldots$ & $\ldots$ & $\ldots$ & $\ldots$ & $\ldots$ & $\ldots$ & $\ldots$ & $\ldots$ & $\ldots$ & $\ldots$ & $\ldots$ & $\ldots$ & $\ldots$ & $\ldots$ & 26 \\
\hline $892-052$ & -2.97 & 1.35 & 1.52 & $\ldots$ & $\ldots$ & 1.30 & $\ldots$ & $\ldots$ & $\ldots$ & $\ldots$ & $\ldots$ & $\ldots$ & $\ldots$ & $\ldots$ & $\ldots$ & $\ldots$ & $\ldots$ & $\ldots$ & $\ldots$ & $\ldots$ & $\ldots$ & 3 \\
\hline CS 22892-052 & -3.04 & 1.55 & 1.48 & 1.44 & $\ldots$ & 1.82 & $\ldots$ & $\ldots$ & $\ldots$ & $\ldots$ & $\ldots$ & $\ldots$ & $\ldots$ & $\ldots$ & $\ldots$ & $\ldots$ & $\ldots$ & $\ldots$ & $\ldots$ & $\ldots$ & $\ldots$ & 2 \\
\hline CS 22892-052 & -3.1 & 1.55 & 1.64 & 1.46 & 1.62 & 1.73 & 1.66 & 1.701 & 1.58 & 1.42 & 1.87 & 1.24 & $\ldots$ & 1.67 & 1.65 & 1.57 & 0.85 & $<1.20$ & $\ldots$ & 1.36 & $<0.9$ & 18 \\
\hline CS 22892-052 & -3.00 & 1.43 & 1.54 & 1.44 & 1.44 & 1.60 & 1.66 & 1.601 & 1.47 & 1.36 & 1.87 & 1.24 & $\ldots$ & 1.67 & 1.65 & 1.57 & 0.85 & $<1.20$ & $\ldots$ & 1.39 & $<1.2$ & adopted \\
\hline $\begin{array}{l}\text { CS 22898-027 } \\
\end{array}$ & -2.15 & $\ldots$ & 1.94 & $\ldots$ & $\ldots$ & & $\ldots$ & $\ldots$ & $\ldots$ & $\ldots$ & $\ldots$ & $\ldots$ & $\ldots$ & $\ldots$ & $\ldots$ & $\ldots$ & $\ldots$ & $\ldots$ & $\ldots$ & $\ldots$ & $\ldots$ & 8 \\
\hline CS 22898-027 & -2.26 & 2.08 & 1.88 & $\ldots$ & $\ldots$ & 1.78 & $\ldots$ & 2.40 & $\ldots$ & $\ldots$ & $\ldots$ & $\ldots$ & $\ldots$ & $\ldots$ & $\ldots$ & $\ldots$ & $\ldots$ & 2.84 & $\ldots$ & $\ldots$ & $\ldots$ & 13 \\
\hline CS 22898-027 & -2.36 & $\ldots$ & 2.04 & $\ldots$ & $\ldots$ & $\ldots$ & $\ldots$ & $\ldots$ & $\ldots$ & $\ldots$ & $\ldots$ & $\ldots$ & $\ldots$ & $\ldots$ & $\ldots$ & $\ldots$ & $\ldots$ & $\ldots$ & $\ldots$ & $\ldots$ & $\ldots$ & 2 \\
\hline CS 22898-027 & -2.26 & 2.08 & 1.95 & $\ldots$ & $\ldots$ & 1.78 & $\ldots$ & 2.40 & $\ldots$ & $\ldots$ & $\ldots$ & $\ldots$ & $\ldots$ & $\ldots$ & $\ldots$ & $\ldots$ & $\ldots$ & 2.84 & $\ldots$ & $\ldots$ & $\ldots$ & adopted \\
\hline$\overline{C S} 22942-019$ & -2.64 & 1.64 & 0.79 & $\ldots$ & $\ldots$ & 0.84 & $\ldots$ & $\ldots$ & $\ldots$ & $\ldots$ & $\ldots$ & $\ldots$ & $\ldots$ & $\ldots$ & $\ldots$ & $\ldots$ & $\ldots$ & $<1.6$ & $\ldots$ & $\ldots$ & $\ldots$ & 13 \\
\hline $42-019$ & -2.67 & . & 0.8 & $\ldots$ & $\ldots$ & $\ldots$ & $\ldots$ & $\ldots$ & $\ldots$ & $\ldots$ & $\ldots$ & $\ldots$ & $\ldots$ & $\ldots$ & $\ldots$ & $\ldots$ & $\ldots$ & $\ldots$ & $\ldots$ & $\ldots$ & $\ldots$ & 8 \\
\hline CS 22942-019 & -2.43 & 0.66 & $\ldots$ & $\ldots$ & $\ldots$ & $\ldots$ & $\ldots$ & $\ldots$ & $\ldots$ & $\ldots$ & $\ldots$ & $\ldots$ & $\ldots$ & $\ldots$ & $\ldots$ & $\ldots$ & $\ldots$ & $<2.03$ & $\ldots$ & $\ldots$ & $\ldots$ & 46 \\
\hline CS 22942-019 & -2.60 & 1.15 & 0.80 & $\ldots$ & $\ldots$ & 0.84 & $\ldots$ & $\ldots$ & $\ldots$ & $\ldots$ & $\ldots$ & $\ldots$ & $\ldots$ & $\ldots$ & $\ldots$ & $\ldots$ & $\ldots$ & $<1.81$ & $\ldots$ & $\ldots$ & $\ldots$ & adopted \\
\hline CS 22945-017 & -2.52 & $<1.20$ & $\ldots$ & $\ldots$ & $\ldots$ & $\ldots$ & $\ldots$ & $\ldots$ & $\ldots$ & $\ldots$ & $\ldots$ & $\ldots$ & $\ldots$ & $\ldots$ & $\ldots$ & $\ldots$ & $\ldots$ & $<2.22$ & $\ldots$ & $\ldots$ & $\ldots$ & 46 \\
\hline CS 22947-187 & -2.49 & $\ldots$ & 0.73 & 1.31 & $\ldots$ & $\ldots$ & $\ldots$ & $\ldots$ & $\ldots$ & $\ldots$ & $\ldots$ & $\ldots$ & $\ldots$ & $\ldots$ & $\ldots$ & $\ldots$ & $\ldots$ & $\ldots$ & $\ldots$ & $\ldots$ & $\ldots$ & 2 \\
\hline CS 22948-027 & -2.21 & $\ldots$ & $\ldots$ & $\ldots$ & $\ldots$ & $\ldots$ & $\ldots$ & $\ldots$ & $\ldots$ & $\ldots$ & $\ldots$ & $\ldots$ & $\ldots$ & $\ldots$ & $\ldots$ & $\ldots$ & $\ldots$ & $\ldots$ & $\ldots$ & $\ldots$ & $\ldots$ & 37 \\
\hline CS 22948-027 & -2.47 & $\ldots$ & 1.88 & $\ldots$ & $\ldots$ & 1.60 & $\ldots$ & $\ldots$ & $\ldots$ & $\ldots$ & $\ldots$ & $\ldots$ & $\ldots$ & $\ldots$ & $\ldots$ & $\ldots$ & $\ldots$ & 2.72 & $\ldots$ & $\ldots$ & $\ldots$ & 29 \\
\hline CS 22948-027 & -2.47 & $\ldots$ & 2.10 & $\ldots$ & $\ldots$ & 1.60 & $\ldots$ & $\ldots$ & $\ldots$ & $\ldots$ & $\ldots$ & $\ldots$ & $\ldots$ & $\ldots$ & $\ldots$ & $\ldots$ & $\ldots$ & $\ldots$ & $\ldots$ & $\ldots$ & $\ldots$ & 5 \\
\hline CS 22948-027 & -2.57 & $\ldots$ & $\ldots$ & $\ldots$ & $\ldots$ & $\ldots$ & $\ldots$ & $\ldots$ & $\ldots$ & $\ldots$ & $\ldots$ & $\ldots$ & $\ldots$ & $\ldots$ & $\ldots$ & $\ldots$ & $\ldots$ & $\ldots$ & $\ldots$ & $\ldots$ & $\ldots$ & 8 \\
\hline CS 22948-027 & -2.57 & $\ldots$ & 1.57 & $\ldots$ & $\ldots$ & $\ldots$ & $\ldots$ & $\ldots$ & $\ldots$ & $\ldots$ & $\ldots$ & $\ldots$ & $\ldots$ & $\ldots$ & $\ldots$ & $\ldots$ & $\ldots$ & $\ldots$ & $\ldots$ & $\ldots$ & $\ldots$ & 10 \\
\hline CS 22948-027 & -2.46 & $\ldots$ & 1.85 & $\ldots$ & $\ldots$ & 1.60 & $\ldots$ & $\ldots$ & $\ldots$ & $\ldots$ & $\ldots$ & $\ldots$ & $\ldots$ & $\ldots$ & $\ldots$ & $\ldots$ & $\ldots$ & 2.72 & $\ldots$ & $\ldots$ & $\ldots$ & adopted \\
\hline $\begin{array}{l}\text { CS 22949-037 } \\
\end{array}$ & -3.79 & $\ldots$ & $<0.93$ & $\ldots$ & $\ldots$ & $\ldots$ & $\ldots$ & $\ldots$ & $\ldots$ & $\ldots$ & $\ldots$ & $\ldots$ & $\ldots$ & $\ldots$ & $\ldots$ & $\ldots$ & $\ldots$ & $\ldots$ & $\ldots$ & $\ldots$ & $\ldots$ & 6 \\
\hline CS 22949-037 & -3.79 & $\ldots$ & $\ldots$ & $\ldots$ & $\ldots$ & $\ldots$ & $\ldots$ & $\ldots$ & $\ldots$ & $\ldots$ & $\ldots$ & $\ldots$ & $\ldots$ & $\ldots$ & $\ldots$ & $\ldots$ & $\ldots$ & $\ldots$ & $\ldots$ & $\ldots$ & $\ldots$ & 15 \\
\hline 9-037 & -4.0 & $<1.14$ & $<0.04$ & $\ldots$ & $\ldots$ & $\ldots$ & $\ldots$ & $\ldots$ & $\ldots$ & $\ldots$ & $\ldots$ & $\ldots$ & $\ldots$ & $\ldots$ & $\ldots$ & $\ldots$ & $\ldots$ & $\ldots$ & $\ldots$ & $\ldots$ & $\ldots$ & 14 \\
\hline 49-037 & -3.79 & $\ldots$ & $<0.73$ & $\ldots$ & $\ldots$ & $\ldots$ & $\ldots$ & $\ldots$ & $\ldots$ & $\ldots$ & $\ldots$ & $\ldots$ & $\ldots$ & $\ldots$ & $\ldots$ & $\ldots$ & $\ldots$ & $\ldots$ & $\ldots$ & $\ldots$ & $\ldots$ & 40 \\
\hline CS 22949-037 & -3.84 & $<1.14$ & $<0.57$ & $\ldots$ & $\ldots$ & $\ldots$ & $\ldots$ & $\ldots$ & $\ldots$ & $\ldots$ & $\ldots$ & $\ldots$ & $\ldots$ & $\ldots$ & $\ldots$ & $\ldots$ & $\ldots$ & $\ldots$ & $\ldots$ & $\ldots$ & $\ldots$ & adopted \\
\hline CS 22956-028 & -2.33 & $<0.91$ & $\ldots$ & $\ldots$ & $\ldots$ & $\ldots$ & $\ldots$ & $\ldots$ & $\ldots$ & $\ldots$ & $\ldots$ & $\ldots$ & $\ldots$ & $\ldots$ & $\ldots$ & $\ldots$ & $\ldots$ & $<1.33$ & $\ldots$ & $\ldots$ & $\ldots$ & 46 \\
\hline-027 & -2.97 & $\ldots$ & $\ldots$ & $\ldots$ & $\ldots$ & $\ldots$ & $\ldots$ & $\ldots$ & $\ldots$ & $\ldots$ & $\ldots$ & $\ldots$ & $\ldots$ & $\ldots$ & $\ldots$ & $\ldots$ & $\ldots$ & $\ldots$ & $\ldots$ & $\ldots$ & $\ldots$ & 8 \\
\hline 7-027 & -3.07 & $\ldots$ & $<0.97$ & $\ldots$ & $\ldots$ & $\ldots$ & $\ldots$ & $\ldots$ & $\ldots$ & $\ldots$ & $\ldots$ & $\ldots$ & $\ldots$ & $\ldots$ & $\ldots$ & $\ldots$ & $\ldots$ & $\ldots$ & $\ldots$ & $\ldots$ & $\ldots$ & 31 \\
\hline CS $22957-027$ & -3.12 & $\ldots$ & $\ldots$ & $\ldots$ & $\ldots$ & $\ldots$ & $\ldots$ & $\ldots$ & $\ldots$ & $\ldots$ & $\ldots$ & $\ldots$ & $\ldots$ & $\ldots$ & $\ldots$ & $\ldots$ & $\ldots$ & $\ldots$ & $\ldots$ & $\ldots$ & $\ldots$ & 11 \\
\hline CS 22957-027 & -3.12 & $\ldots$ & $\ldots$ & $\ldots$ & $\ldots$ & $\ldots$ & $\ldots$ & $\ldots$ & $\ldots$ & $\ldots$ & $\ldots$ & $\ldots$ & $\ldots$ & $\ldots$ & $\ldots$ & $\ldots$ & $\ldots$ & $\ldots$ & $\ldots$ & $\ldots$ & $\ldots$ & 12 \\
\hline CS 22957-027 & -3.07 & $\ldots$ & $<0.97$ & $\ldots$ & $\ldots$ & $\ldots$ & $\ldots$ & $\ldots$ & $\ldots$ & $\ldots$ & $\ldots$ & $\ldots$ & $\ldots$ & $\ldots$ & $\ldots$ & $\ldots$ & $\ldots$ & $\ldots$ & $\ldots$ & $\ldots$ & $\ldots$ & adopted \\
\hline CS 22958-042 & -2.85 & $\ldots$ & $\ldots$ & $\ldots$ & $\ldots$ & $\ldots$ & $\ldots$ & $\ldots$ & $\ldots$ & $\ldots$ & $\ldots$ & $\ldots$ & $\ldots$ & $\ldots$ & $\ldots$ & $\ldots$ & $\ldots$ & $\ldots$ & $\ldots$ & $\ldots$ & $\ldots$ & 33 \\
\hline$\overline{C S} 22960-053$ & -3.14 & $\ldots$ & $\ldots$ & $\ldots$ & $\ldots$ & $\ldots$ & $\ldots$ & $\ldots$ & $\ldots$ & $\ldots$ & $\ldots$ & $\ldots$ & $\ldots$ & $\ldots$ & $\ldots$ & $\ldots$ & $\ldots$ & 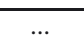 & $\ldots$ & $\ldots$ & $\ldots$ & 37 \\
\hline CS 22964-161 & -2.43 & $\ldots$ & 0.69 & $\ldots$ & $\ldots$ & $\ldots$ & $\ldots$ & $\ldots$ & $\ldots$ & 0.64 & $\ldots$ & $\ldots$ & $\ldots$ & $\ldots$ & $\ldots$ & $\ldots$ & $\ldots$ & 2.19 & $\ldots$ & $\ldots$ & $\ldots$ & 42 \\
\hline CS 29497-030 & -2.57 & $\ldots$ & 1.99 & 2.09 & $\ldots$ & 1.78 & 1.87 & 2.08 & $\ldots$ & 2.30 & $\ldots$ & 2.32 & $\ldots$ & $<2.52$ & $<2.52$ & $<2.27$ & $\ldots$ & 3.65 & 3.37 & $\ldots$ & $\ldots$ & 27 \\
\hline CS 29497-030 & -2.77 & $\ldots$ & 1.44 & $\ldots$ & $\ldots$ & $\ldots$ & $\ldots$ & $\ldots$ & $\ldots$ & $\ldots$ & $\ldots$ & $\ldots$ & $\ldots$ & $\ldots$ & $\ldots$ & $\ldots$ & $\ldots$ & 3.55 & $\ldots$ & $\ldots$ & $\ldots$ & 21 \\
\hline CS 29497-030 & -2.67 & $\ldots$ & 1.72 & 2.09 & $\ldots$ & 1.78 & 1.87 & 2.08 & $\ldots$ & 2.30 & $\ldots$ & 2.32 & $\ldots$ & $<2.52$ & $<2.52$ & $<2.27$ & $\ldots$ & 3.60 & 3.37 & $\ldots$ & $\ldots$ & adopted \\
\hline CS 29497-034 & -2.90 & $\ldots$ & 1.80 & $\ldots$ & $\ldots$ & 1.50 & $\ldots$ & $\ldots$ & $\ldots$ & $\ldots$ & $\ldots$ & $\ldots$ & $\ldots$ & $\ldots$ & $\ldots$ & $\ldots$ & $\ldots$ & 2.95 & $\ldots$ & $\ldots$ & $\ldots$ & 29 \\
\hline CS 29497-034 & -2.91 & $\ldots$ & 2.25 & $\ldots$ & $\ldots$ & 1.50 & $\ldots$ & $\ldots$ & $\ldots$ & $\ldots$ & $\ldots$ & $\ldots$ & $\ldots$ & $\ldots$ & $\ldots$ & $\ldots$ & $\ldots$ & $\ldots$ & $\ldots$ & $\ldots$ & $\ldots$ & 5 \\
\hline CS 29497-034 & -2.91 & $\ldots$ & $\ldots$ & $\ldots$ & $\ldots$ & $\ldots$ & $\ldots$ & $\ldots$ & $\ldots$ & $\ldots$ & $\ldots$ & $\ldots$ & $\ldots$ & $\ldots$ & $\ldots$ & $\ldots$ & $\ldots$ & $\ldots$ & $\ldots$ & $\ldots$ & $\ldots$ & 37 \\
\hline CS 29497-034 & -2.90 & $\ldots$ & 1.80 & $\ldots$ & $\ldots$ & 1.50 & $\ldots$ & $\ldots$ & $\ldots$ & $\ldots$ & $\ldots$ & $\ldots$ & $\ldots$ & $\ldots$ & $\ldots$ & $\ldots$ & $\ldots$ & 2.95 & $\ldots$ & $\ldots$ & $\ldots$ & adopted \\
\hline$\overline{C S} 29498-043$ & -3.54 & $\ldots$ & $\ldots$ & $\ldots$ & $\ldots$ & $\ldots$ & $\ldots$ & $\ldots$ & $\ldots$ & $\ldots$ & $\ldots$ & $\ldots$ & $\ldots$ & $\ldots$ & $\ldots$ & $\ldots$ & $\ldots$ & $\ldots$ & $\ldots$ & $\ldots$ & $\ldots$ & 25 \\
\hline CS 29498-043 & -3.75 & $\ldots$ & $\ldots$ & $\ldots$ & $\ldots$ & $\ldots$ & $\ldots$ & $\ldots$ & $\ldots$ & $\ldots$ & $\ldots$ & $\ldots$ & $\ldots$ & $\ldots$ & $\ldots$ & $\ldots$ & $\ldots$ & $\ldots$ & $\ldots$ & $\ldots$ & $\ldots$ & 11 \\
\hline CS 29498-043 & -3.75 & $\ldots$ & $\ldots$ & $\ldots$ & $\ldots$ & $\ldots$ & $\ldots$ & $\ldots$ & $\ldots$ & $\ldots$ & $\ldots$ & $\ldots$ & $\ldots$ & $\ldots$ & $\ldots$ & $\ldots$ & $\ldots$ & $\ldots$ & $\ldots$ & $\ldots$ & $\ldots$ & 12 \\
\hline CS 29498-043 & -3.54 & $\ldots$ & $\ldots$ & $\ldots$ & $\ldots$ & $\ldots$ & $\ldots$ & $\ldots$ & $\ldots$ & $\ldots$ & $\ldots$ & $\ldots$ & $\ldots$ & $\ldots$ & $\ldots$ & $\ldots$ & $\ldots$ & $\ldots$ & $\ldots$ & $\ldots$ & $\ldots$ & adopted \\
\hline CS 29502-092 & -2.76 & $\ldots$ & 0.4 & $\ldots$ & $\ldots$ & $\ldots$ & $\ldots$ & $\ldots$ & $\ldots$ & $\ldots$ & $\ldots$ & $\ldots$ & $\ldots$ & $\ldots$ & $\ldots$ & $\ldots$ & $\ldots$ & $\ldots$ & $\ldots$ & $\ldots$ & $\ldots$ & 10 \\
\hline CS 29503-010 & -1.06 & $\ldots$ & $\ldots$ & $\ldots$ & $\ldots$ & $\ldots$ & $\ldots$ & $\ldots$ & $\ldots$ & $\ldots$ & $\ldots$ & $\ldots$ & $\ldots$ & $\ldots$ & $\ldots$ & $\ldots$ & $\ldots$ & $\ldots$ & $\ldots$ & $\ldots$ & $\ldots$ & 37 \\
\hline CS 29526-110 & -2.06 & $\ldots$ & $\ldots$ & $\ldots$ & $\ldots$ & $\ldots$ & $\ldots$ & $\ldots$ & $\ldots$ & $\ldots$ & $\ldots$ & $\ldots$ & & $\ldots$ & $\ldots$ & $\ldots$ & $\ldots$ & 3.16 & $\ldots$ & $\ldots$ & $\ldots$ & 41 \\
\hline CS 29526-110 & -2.38 & $\ldots$ & 1.73 & $\ldots$ & $\ldots$ & $\ldots$ & $\ldots$ & $\ldots$ & $\ldots$ & $\ldots$ & $\ldots$ & $\ldots$ & & $\ldots$ & $\ldots$ & $\ldots$ & $\ldots$ & 3.3 & $\ldots$ & $\ldots$ & $\ldots$ & 13 \\
\hline CS 29526-110 & -2.06 & $\ldots$ & 1.73 & $\ldots$ & $\ldots$ & $\ldots$ & $\ldots$ & $\ldots$ & $\ldots$ & $\ldots$ & $\ldots$ & $\ldots$ & $\ldots$ & $\ldots$ & $\ldots$ & $\ldots$ & $\ldots$ & 3.16 & $\ldots$ & $\ldots$ & $\ldots$ & adopted \\
\hline
\end{tabular}


D. M. Allen et al.: Elemental abundances and classification of CEMP stars

Table B.4. continued.

\begin{tabular}{|c|c|c|c|c|c|c|c|c|c|c|c|c|c|c|c|c|c|c|c|c|c|c|}
\hline Star & {$[\mathrm{Fe} / \mathrm{H}]$} & $\mathrm{Sm}$ & $\mathrm{Eu}$ & $\mathrm{Gd}$ & $\mathrm{Tb}$ & Dy & Ho & $\mathrm{Er}$ & $\mathrm{Tm}$ & $\mathrm{Yb}$ & $\mathrm{Lu}$ & Hf & W & Os & $\mathrm{Ir}$ & $\mathrm{Pt}$ & $\mathrm{Au}$ & $\mathrm{Pb}$ & $\mathrm{Bi}$ & Th & $\mathrm{U}$ & Ref. \\
\hline CS 29528-028 & -2.86 & $\ldots$ & $\ldots$ & $\ldots$ & $\ldots$ & $\ldots$ & $\ldots$ & $\ldots$ & $\ldots$ & $\ldots$ & $\ldots$ & $\ldots$ & $\ldots$ & $\ldots$ & $\ldots$ & $\ldots$ & $\ldots$ & $\ldots$ & $\ldots$ & $\ldots$ & $\ldots$ & 37 \\
\hline CS 29528-041 & -3.30 & $\ldots$ & $\ldots$ & $\ldots$ & $\ldots$ & $\ldots$ & $\ldots$ & $\ldots$ & $\ldots$ & $\ldots$ & $\ldots$ & $\ldots$ & $\ldots$ & $\ldots$ & $\ldots$ & $\ldots$ & $\ldots$ & $\ldots$ & $\ldots$ & $\ldots$ & $\ldots$ & 33 \\
\hline$\overline{C S} 30301-015$ & -2.64 & 0.85 & 0.2 & $\ldots$ & $\ldots$ & 0.57 & $\ldots$ & $\ldots$ & $\ldots$ & $\ldots$ & $\ldots$ & $\ldots$ & $\ldots$ & $\ldots$ & $\ldots$ & $\ldots$ & $\ldots$ & 1.7 & $\ldots$ & $\ldots$ & $\ldots$ & 13 \\
\hline CS 30314-067 & -2.85 & $\ldots$ & $<-0.5$ & $\ldots$ & $\ldots$ & $\ldots$ & $\ldots$ & $\ldots$ & $\ldots$ & $\ldots$ & $\ldots$ & $\ldots$ & $\ldots$ & $\ldots$ & $\ldots$ & $\ldots$ & $\ldots$ & $\ldots$ & $\ldots$ & $\ldots$ & $\ldots$ & 10 \\
\hline CS 30322-023 & -3.25 & $\ldots$ & $\ldots$ & $\ldots$ & $\ldots$ & $\ldots$ & $\ldots$ & $\ldots$ & $\ldots$ & $\ldots$ & $\ldots$ & $\ldots$ & $\ldots$ & $\ldots$ & $\ldots$ & $\ldots$ & $\ldots$ & $\ldots$ & $\ldots$ & $\ldots$ & $\ldots$ & 37 \\
\hline CS 30338-089 & -2.45 & $\ldots$ & $\ldots$ & $\ldots$ & $\ldots$ & $\ldots$ & $\ldots$ & $\ldots$ & $\ldots$ & $\ldots$ & $\ldots$ & $\ldots$ & $\ldots$ & $\ldots$ & $\ldots$ & $\ldots$ & $\ldots$ & $\ldots$ & $\ldots$ & $\ldots$ & $\ldots$ & 37 \\
\hline$\overline{C S} 31062-012$ & -2.55 & $\ldots$ & 1.62 & $\ldots$ & $\ldots$ & $\ldots$ & $\ldots$ & $\ldots$ & $\ldots$ & $\ldots$ & $\ldots$ & $\ldots$ & $\ldots$ & $\ldots$ & $\ldots$ & $\ldots$ & $\ldots$ & 2.4 & $\ldots$ & $\ldots$ & $\ldots$ & 13 \\
\hline CS 31062-012 & -2.74 & $<2.21$ & 1.40 & $\ldots$ & $\ldots$ & $\ldots$ & $\ldots$ & $\ldots$ & $\ldots$ & $\ldots$ & $\ldots$ & $\ldots$ & $\ldots$ & $\ldots$ & $\ldots$ & $\ldots$ & $\ldots$ & 2.28 & $\ldots$ & $\ldots$ & $\ldots$ & 9 \\
\hline CS 31062-012 & -2.74 & $<2.21$ & 1.40 & $\ldots$ & $\ldots$ & $\ldots$ & $\ldots$ & $\ldots$ & $\ldots$ & $\ldots$ & $\ldots$ & $\ldots$ & $\ldots$ & $\ldots$ & $\ldots$ & $\ldots$ & $\ldots$ & $\ldots$ & $\ldots$ & $\ldots$ & $\ldots$ & 3 \\
\hline CS 31062-012 & -2.53 & $\ldots$ & $\ldots$ & $\ldots$ & $\ldots$ & $\ldots$ & $\ldots$ & $\ldots$ & $\ldots$ & $\ldots$ & $\ldots$ & $\ldots$ & $\ldots$ & $\ldots$ & $\ldots$ & $\ldots$ & $\ldots$ & 2.53 & $\ldots$ & $\ldots$ & $\ldots$ & 41 \\
\hline CS 31062-012 & -2.53 & $<2.21$ & 1.62 & $\ldots$ & $\ldots$ & $\ldots$ & $\ldots$ & $\ldots$ & $\ldots$ & $\ldots$ & $\ldots$ & $\ldots$ & $\ldots$ & $\ldots$ & $\ldots$ & $\ldots$ & $\ldots$ & 2.53 & $\ldots$ & $\ldots$ & $\ldots$ & adopted \\
\hline CS 31062-050 & -2.31 & 2.15 & 1.84 & $\ldots$ & $\ldots$ & 2.08 & $\ldots$ & $\ldots$ & $\ldots$ & $\ldots$ & $\ldots$ & $\ldots$ & $\ldots$ & $\ldots$ & $\ldots$ & $\ldots$ & $\ldots$ & 2.9 & $\ldots$ & $\ldots$ & $\ldots$ & 13 \\
\hline CS 31062-050 & -2.3 & $\ldots$ & 1.91 & $\ldots$ & $\ldots$ & $\ldots$ & $\ldots$ & $\ldots$ & $\ldots$ & 1.8 & $\ldots$ & 2.21 & $\ldots$ & 1.72 & 1.39 & $\ldots$ & $\ldots$ & 2.87 & $\ldots$ & $\ldots$ & $\ldots$ & 34 \\
\hline CS 31062-050 & -2.42 & 1.96 & 1.79 & 1.83 & 1.50 & 1.63 & 1.55 & 2.22 & 1.97 & 2.21 & 2.18 & 2.33 & $\ldots$ & $\ldots$ & $\ldots$ & $\ldots$ & $\ldots$ & 2.81 & $\ldots$ & $\ldots$ & $\ldots$ & 24 \\
\hline CS 31062-050 & -2.37 & 2.06 & 1.85 & 1.83 & 1.50 & 1.86 & 1.55 & 2.22 & 1.97 & 2.00 & 2.18 & 2.27 & $\ldots$ & 1.72 & 1.39 & $\ldots$ & $\ldots$ & 2.84 & $\ldots$ & $\ldots$ & $\ldots$ & adopted \\
\hline$\overline{C S} 31080-095$ & -2.85 & $\ldots$ & $\ldots$ & $\ldots$ & $\ldots$ & $\ldots$ & $\ldots$ & $\ldots$ & $\ldots$ & $\ldots$ & $\ldots$ & $\ldots$ & $\ldots$ & $\ldots$ & $\ldots$ & $\ldots$ & $\ldots$ & $\ldots$ & $\ldots$ & $\ldots$ & $\ldots$ & 33 \\
\hline G77-61 & -4.03 & $\ldots$ & $<3$ & $\ldots$ & $\ldots$ & $\ldots$ & $\ldots$ & $\ldots$ & $\ldots$ & $\ldots$ & $\ldots$ & $\ldots$ & $\ldots$ & $\ldots$ & $\ldots$ & $\ldots$ & $\ldots$ & $\ldots$ & $\ldots$ & $\ldots$ & $\ldots$ & 28 \\
\hline HD 5223 & -2.06 & 1.68 & $\ldots$ & $\ldots$ & $\ldots$ & $\ldots$ & $\ldots$ & $\ldots$ & $\ldots$ & $\ldots$ & $\ldots$ & $\ldots$ & $\ldots$ & $\ldots$ & $\ldots$ & $\ldots$ & $\ldots$ & 2.21 & $\ldots$ & $\ldots$ & $\ldots$ & 30 \\
\hline HD 187216 & -2.48 & 3.00 & $\ldots$ & 3.00 & $\ldots$ & $\ldots$ & $\ldots$ & $\ldots$ & $\ldots$ & $\ldots$ & $\ldots$ & $\ldots$ & $\ldots$ & $\ldots$ & $\ldots$ & $\ldots$ & $\ldots$ & $\ldots$ & $\ldots$ & $\ldots$ & $\ldots$ & 1 \\
\hline HD 187861 & -2.36 & 1.34 & $\ldots$ & $\ldots$ & $\ldots$ & $\ldots$ & $\ldots$ & $\ldots$ & $\ldots$ & $\ldots$ & $\ldots$ & $\ldots$ & $\ldots$ & $\ldots$ & $\ldots$ & $\ldots$ & $\ldots$ & 2.86 & $\ldots$ & $\ldots$ & $\ldots$ & 46 \\
\hline HD 196944 & -2.25 & 0.78 & 0.17 & $\ldots$ & $\ldots$ & 0.46 & $\ldots$ & 0.81 & $\ldots$ & $\ldots$ & $\ldots$ & $\ldots$ & $\ldots$ & $\ldots$ & $\ldots$ & $\ldots$ & $\ldots$ & 1.9 & $\ldots$ & $\ldots$ & $\ldots$ & 13 \\
\hline HD 196944 & -2.4 & 0.6 & $\ldots$ & $\ldots$ & $\ldots$ & $\ldots$ & $\ldots$ & $\ldots$ & $\ldots$ & $\ldots$ & $\ldots$ & $\ldots$ & $\ldots$ & $\ldots$ & $\ldots$ & $\ldots$ & $\ldots$ & 2.1 & $\ldots$ & $\ldots$ & $\ldots$ & 20 \\
\hline HD 196944 & -2.19 & 0.22 & $\ldots$ & $\ldots$ & $\ldots$ & $\ldots$ & $\ldots$ & $\ldots$ & $\ldots$ & $\ldots$ & $\ldots$ & $\ldots$ & $\ldots$ & $\ldots$ & $\ldots$ & $\ldots$ & $\ldots$ & 1.99 & $\ldots$ & $\ldots$ & $\ldots$ & 46 \\
\hline HD 196944 & -2.30 & 0.53 & 0.17 & $\ldots$ & $\ldots$ & 0.46 & $\ldots$ & 0.81 & $\ldots$ & $\ldots$ & $\ldots$ & $\ldots$ & $\ldots$ & $\ldots$ & $\ldots$ & $\ldots$ & $\ldots$ & 2.0 & $\ldots$ & $\ldots$ & $\ldots$ & adopted \\
\hline HD 209621 & -1.92 & 1.46 & 1.35 & $\ldots$ & $\ldots$ & $\ldots$ & $\ldots$ & 2.06 & $\ldots$ & $\ldots$ & $\ldots$ & $\ldots$ & 2.61 & $\ldots$ & $\ldots$ & $\ldots$ & $\ldots$ & 1.88 & $\ldots$ & $\ldots$ & $\ldots$ & 44 \\
\hline HD 224959 & -2.06 & 1.74 & $\ldots$ & $\ldots$ & $\ldots$ & $\ldots$ & $\ldots$ & $\ldots$ & $\ldots$ & $\ldots$ & $\ldots$ & $\ldots$ & $\ldots$ & $\ldots$ & $\ldots$ & $\ldots$ & $\ldots$ & 3.06 & $\ldots$ & $\ldots$ & $\ldots$ & 46 \\
\hline HE 0012-1441 & -2.52 & $\ldots$ & $\ldots$ & $\ldots$ & $\ldots$ & $\ldots$ & $\ldots$ & $\ldots$ & $\ldots$ & $\ldots$ & $\ldots$ & $\ldots$ & $\ldots$ & $\ldots$ & $\ldots$ & $\ldots$ & $\ldots$ & $<1.92$ & $\ldots$ & $\ldots$ & $\ldots$ & 31 \\
\hline HE 0024-2523 & -2.72 & $\ldots$ & $<1.1$ & $\ldots$ & $\ldots$ & $\ldots$ & $\ldots$ & $\ldots$ & $\ldots$ & $\ldots$ & $\ldots$ & $\ldots$ & $\ldots$ & $\ldots$ & $\ldots$ & $\ldots$ & $\ldots$ & 3.3 & $\ldots$ & $\ldots$ & $\ldots$ & 17 \\
\hline HE 0058-0244 & -2.75 & $\ldots$ & 1.70 & $\ldots$ & $\ldots$ & $\ldots$ & $\ldots$ & $\ldots$ & $\ldots$ & $\ldots$ & $\ldots$ & $\ldots$ & $\ldots$ & $\ldots$ & $\ldots$ & $\ldots$ & $\ldots$ & 2.79 & $\ldots$ & $\ldots$ & $\ldots$ & 31 \\
\hline HE 0107-5240 & -5.30 & $\ldots$ & $<2.78$ & $\ldots$ & $\ldots$ & $\ldots$ & $\ldots$ & $\ldots$ & $\ldots$ & $\ldots$ & $\ldots$ & $\ldots$ & $\ldots$ & $\ldots$ & $\ldots$ & $\ldots$ & $\ldots$ & $\ldots$ & $\ldots$ & $\ldots$ & $\ldots$ & 23 \\
\hline HE 0107-5240 & -5.30 & $\ldots$ & $<2.8$ & $\ldots$ & $\ldots$ & $\ldots$ & $\ldots$ & $\ldots$ & $\ldots$ & $\ldots$ & $\ldots$ & $\ldots$ & $\ldots$ & $\ldots$ & $\ldots$ & $\ldots$ & $\ldots$ & $\ldots$ & $\ldots$ & $\ldots$ & $\ldots$ & 16 \\
\hline HE $0107-5240$ & -5.30 & $\ldots$ & $<2.78$ & $\ldots$ & $\ldots$ & $\ldots$ & $\ldots$ & $\ldots$ & $\ldots$ & $\ldots$ & $\ldots$ & $\ldots$ & $\ldots$ & $\ldots$ & $\ldots$ & $\ldots$ & $\ldots$ & $\ldots$ & $\ldots$ & $\ldots$ & $\ldots$ & adopted \\
\hline HE 0131-3953 & -2.71 & $\ldots$ & 1.62 & $\ldots$ & $\ldots$ & $\ldots$ & $\ldots$ & $\ldots$ & $\ldots$ & $\ldots$ & $\ldots$ & $\ldots$ & $\ldots$ & $\ldots$ & $\ldots$ & $\ldots$ & $\ldots$ & $\ldots$ & $\ldots$ & $\ldots$ & $\ldots$ & 26 \\
\hline HE 0143-0441 & -2.31 & $\ldots$ & 1.46 & $\ldots$ & $\ldots$ & $\ldots$ & $\ldots$ & $\ldots$ & $\ldots$ & $\ldots$ & $\ldots$ & $\ldots$ & $\ldots$ & $\ldots$ & $\ldots$ & $\ldots$ & $\ldots$ & 3.11 & $\ldots$ & $\ldots$ & $\ldots$ & 31 \\
\hline HE 0202-2204 & -1.98 & 1.03 & 0.49 & $\ldots$ & $\ldots$ & $\ldots$ & $\ldots$ & $\ldots$ & $\ldots$ & $\ldots$ & $\ldots$ & $\ldots$ & $\ldots$ & $\ldots$ & $\ldots$ & $\ldots$ & $\ldots$ & 3.11 & $\ldots$ & $\ldots$ & $\ldots 26$ & \\
\hline HE 0206-1916 & -2.09 & $\ldots$ & $\ldots$ & $\ldots$ & $\ldots$ & $\ldots$ & $\ldots$ & $\ldots$ & $\ldots$ & $\ldots$ & $\ldots$ & $\ldots$ & $\ldots$ & $\ldots$ & $\ldots$ & $\ldots$ & $\ldots$ & $\ldots$ & $\ldots$ & $\ldots$ & $\ldots$ & 37 \\
\hline HE 0212-0557 & -3.27 & $\ldots$ & $\ldots$ & $\ldots$ & $\ldots$ & $\ldots$ & $\ldots$ & $\ldots$ & $\ldots$ & $\ldots$ & $\ldots$ & $\ldots$ & $\ldots$ & $\ldots$ & $\ldots$ & $\ldots$ & $\ldots$ & $\ldots$ & $\ldots$ & $\ldots$ & $\ldots$ & 31 \\
\hline HE 0231-4016 & -2.08 & $\ldots$ & $\ldots$ & $\ldots$ & $\ldots$ & $\ldots$ & $\ldots$ & $\ldots$ & $\ldots$ & $\ldots$ & $\ldots$ & $\ldots$ & $\ldots$ & $\ldots$ & $\ldots$ & $\ldots$ & $\ldots$ & $\ldots$ & $\ldots$ & $\ldots$ & $\ldots$ & 26 \\
\hline HE 0336+0113 & -2.68 & $\ldots$ & 1.18 & $\ldots$ & $\ldots$ & $\ldots$ & $\ldots$ & $\ldots$ & $\ldots$ & $\ldots$ & $\ldots$ & $\ldots$ & $\ldots$ & $\ldots$ & $\ldots$ & $\ldots$ & $\ldots$ & $<2.28$ & $\ldots$ & $\ldots$ & $\ldots$ & 31 \\
\hline HE 0338-3945 & -2.42 & $\ldots$ & 1.94 & $\ldots$ & $\ldots$ & $\ldots$ & $\ldots$ & $\ldots$ & $\ldots$ & $\ldots$ & $\ldots$ & $\ldots$ & $\ldots$ & $\ldots$ & $\ldots$ & $\ldots$ & $\ldots$ & $\ldots$ & $\ldots$ & $\ldots$ & $\ldots$ & 32 \\
\hline HE 0338-3945 & -2.41 & $\ldots$ & 1.89 & $\ldots$ & $\ldots$ & $\ldots$ & $\ldots$ & $\ldots$ & $\ldots$ & $\ldots$ & $\ldots$ & $\ldots$ & $\ldots$ & $\ldots$ & $\ldots$ & $\ldots$ & $\ldots$ & $\ldots$ & $\ldots$ & $\ldots$ & $\ldots$ & 26 \\
\hline HE 0338-3945 & -2.41 & $\ldots$ & 1.91 & $\ldots$ & $\ldots$ & $\ldots$ & $\ldots$ & $\ldots$ & $\ldots$ & $\ldots$ & $\ldots$ & $\ldots$ & $\ldots$ & $\ldots$ & $\ldots$ & $\ldots$ & $\ldots$ & $\ldots$ & $\ldots$ & $\ldots$ & $\ldots$ & adopted \\
\hline HE 0400-2030 & -1.73 & $\ldots$ & $\ldots$ & $\ldots$ & $\ldots$ & $\ldots$ & $\ldots$ & $\ldots$ & $\ldots$ & $\ldots$ & $\ldots$ & $\ldots$ & $\ldots$ & $\ldots$ & $\ldots$ & $\ldots$ & $\ldots$ & $\ldots$ & $\ldots$ & $\ldots$ & $\ldots$ & 37 \\
\hline HE 0430-4404 & -2.07 & $\ldots$ & $\ldots$ & $\ldots$ & $\ldots$ & $\ldots$ & $\ldots$ & $\ldots$ & $\ldots$ & $\ldots$ & $\ldots$ & $\ldots$ & $\ldots$ & $\ldots$ & $\ldots$ & $\ldots$ & $\ldots$ & $\ldots$ & $\ldots$ & $\ldots$ & $\ldots$ & 26 \\
\hline HE 0441-0652 & -2.47 & $\ldots$ & $\ldots$ & $\ldots$ & $\ldots$ & $\ldots$ & $\ldots$ & $\ldots$ & $\ldots$ & $\ldots$ & $\ldots$ & $\ldots$ & $\ldots$ & $\ldots$ & $\ldots$ & $\ldots$ & $\ldots$ & $\ldots$ & $\ldots$ & $\ldots$ & $\ldots$ & 37 \\
\hline HE 0507-1653 & -1.38 & $\ldots$ & $\ldots$ & $\ldots$ & $\ldots$ & $\ldots$ & $\ldots$ & $\ldots$ & $\ldots$ & $\ldots$ & $\ldots$ & $\ldots$ & $\ldots$ & $\ldots$ & $\ldots$ & $\ldots$ & $\ldots$ & $\ldots$ & $\ldots$ & $\ldots$ & $\ldots$ & 37 \\
\hline HE 0557-4840 & -4.75 & $\ldots$ & $<2.04$ & $\ldots$ & $\ldots$ & $\ldots$ & $\ldots$ & $\ldots$ & $\ldots$ & $\ldots$ & $\ldots$ & $\ldots$ & $\ldots$ & $\ldots$ & $\ldots$ & $\ldots$ & $\ldots$ & $\ldots$ & $\ldots$ & $\ldots$ & $\ldots$ & 38 \\
\hline HE 1001-0243 & -2.88 & -0.04 & $\ldots$ & $\ldots$ & $\ldots$ & $\ldots$ & $\ldots$ & $\ldots$ & $\ldots$ & $\ldots$ & $\ldots$ & $\ldots$ & $\ldots$ & $\ldots$ & $\ldots$ & $\ldots$ & $\ldots$ & $<1.38$ & $\ldots$ & $\ldots$ & $\ldots$ & 46 \\
\hline HE 1005-1439 & -3.17 & $\ldots$ & $\ldots$ & $\ldots$ & $\ldots$ & $\ldots$ & $\ldots$ & $\ldots$ & $\ldots$ & $\ldots$ & $\ldots$ & $\ldots$ & $\ldots$ & $\ldots$ & $\ldots$ & $\ldots$ & $\ldots$ & $\ldots$ & $\ldots$ & $\ldots$ & $\ldots$ & 37 \\
\hline HE 1012-1540 & -3.43 & $\ldots$ & $<1.62$ & $\ldots$ & $\ldots$ & $\ldots$ & $\ldots$ & $\ldots$ & $\ldots$ & $\ldots$ & $\ldots$ & $\ldots$ & $\ldots$ & $\ldots$ & $\ldots$ & $\ldots$ & $\ldots$ & $\ldots$ & $<2.93$ & $\ldots$ & $\ldots$ & 40 \\
\hline HE 1031-0020 & -3.86 & $\ldots$ & $<0.87$ & $\ldots$ & $\ldots$ & $\ldots$ & $\ldots$ & $\ldots$ & $\ldots$ & $\ldots$ & $\ldots$ & $\ldots$ & $\ldots$ & $\ldots$ & $\ldots$ & $\ldots$ & $\ldots$ & 2.66 & $\ldots$ & $\ldots$ & $\ldots$ & 31 \\
\hline HE $1105+0027$ & -2.42 & $\ldots$ & 1.81 & $\ldots$ & $\ldots$ & $\ldots$ & $\ldots$ & $\ldots$ & $\ldots$ & $\ldots$ & $\ldots$ & $\ldots$ & $\ldots$ & $\ldots$ & $\ldots$ & $\ldots$ & $\ldots$ & $\ldots$ & $\ldots$ & $\ldots$ & $\ldots$ & 26 \\
\hline HE $1135+0139$ & -2.33 & $\ldots$ & 0.33 & $\ldots$ & $\ldots$ & $\ldots$ & $\ldots$ & $\ldots$ & $\ldots$ & $\ldots$ & $\ldots$ & $\ldots$ & $\ldots$ & $\ldots$ & $\ldots$ & $\ldots$ & $\ldots$ & $\ldots$ & $\ldots$ & $\ldots$ & $\ldots$ & 26 \\
\hline HE 1135-0344 & -2.63 & $\ldots$ & $\ldots$ & $\ldots$ & $\ldots$ & $\ldots$ & $\ldots$ & $\ldots$ & $\ldots$ & $\ldots$ & $\ldots$ & $\ldots$ & $\ldots$ & $\ldots$ & $\ldots$ & $\ldots$ & $\ldots$ & $\ldots$ & $\ldots$ & $\ldots$ & $\ldots$ & 26 \\
\hline HE 1150-0428 & -3.30 & $\ldots$ & $<1.45$ & $\ldots$ & $\ldots$ & $\ldots$ & $\ldots$ & $\ldots$ & $\ldots$ & $\ldots$ & $\ldots$ & $\ldots$ & $\ldots$ & $\ldots$ & $\ldots$ & $\ldots$ & $\ldots$ & $\ldots$ & $\ldots$ & $\ldots$ & $\ldots$ & 31 \\
\hline HE 1157-0518 & -2.34 & $\ldots$ & $\ldots$ & $\ldots$ & $\ldots$ & $\ldots$ & $\ldots$ & $\ldots$ & $\ldots$ & $\ldots$ & $\ldots$ & $\ldots$ & $\ldots$ & $\ldots$ & $\ldots$ & $\ldots$ & $\ldots$ & $\ldots$ & $\ldots$ & $\ldots$ & $\ldots$ & 37 \\
\hline HE 1221-1948 & -3.36 & $\ldots$ & $\ldots$ & $\ldots$ & $\ldots$ & $\ldots$ & $\ldots$ & $\ldots$ & $\ldots$ & $\ldots$ & $\ldots$ & $\ldots$ & $\ldots$ & $\ldots$ & $\ldots$ & $\ldots$ & $\ldots$ & $\ldots$ & $\ldots$ & $\ldots$ & $\ldots$ & 26 \\
\hline HE 1249-3121 & -3.23 & $\ldots$ & $\ldots$ & $\ldots$ & $\ldots$ & $\ldots$ & $\ldots$ & $\ldots$ & $\ldots$ & $\ldots$ & $\ldots$ & $\ldots$ & $\ldots$ & $\ldots$ & $\ldots$ & $\ldots$ & $\ldots$ & $\ldots$ & $\ldots$ & $\ldots$ & $\ldots$ & 26 \\
\hline HE $1300+0157$ & -3.39 & $\ldots$ & $\ldots$ & $\ldots$ & $\ldots$ & $\ldots$ & $\ldots$ & $\ldots$ & $\ldots$ & $\ldots$ & $\ldots$ & $\ldots$ & $\ldots$ & $\ldots$ & $\ldots$ & $\ldots$ & $\ldots$ & $\ldots$ & $\ldots$ & $\ldots$ & $\ldots$ & 40 \\
\hline HE $1300+0157$ & -3.53 & $\ldots$ & $<-1.56$ & $\ldots$ & $\ldots$ & $\ldots$ & $\ldots$ & $\ldots$ & $\ldots$ & $\ldots$ & $\ldots$ & $\ldots$ & $\ldots$ & $\ldots$ & $\ldots$ & $\ldots$ & $\ldots$ & $<2.78$ & $\ldots$ & $\ldots$ & $\ldots$ & 36 \\
\hline HE $1300+0157$ & -3.76 & $\ldots$ & $\ldots$ & $\ldots$ & $\ldots$ & $\ldots$ & $\ldots$ & $\ldots$ & $\ldots$ & $\ldots$ & $\ldots$ & $\ldots$ & $\ldots$ & $\ldots$ & $\ldots$ & $\ldots$ & $\ldots$ & $\ldots$ & $\ldots$ & $\ldots$ & $\ldots$ & 26 \\
\hline HE $1300+0157$ & -3.56 & $\ldots$ & $<-1.56$ & $\ldots$ & $\ldots$ & $\ldots$ & $\ldots$ & $\ldots$ & $\ldots$ & $\ldots$ & $\ldots$ & $\ldots$ & $\ldots$ & $\ldots$ & $\ldots$ & $\ldots$ & $\ldots$ & $<2.78$ & $\ldots$ & $\ldots$ & $\ldots$ & adopted \\
\hline HE 1300-0641 & -3.14 & $\ldots$ & $\ldots$ & $\ldots$ & $\ldots$ & $\ldots$ & $\ldots$ & $\ldots$ & $\ldots$ & $\ldots$ & $\ldots$ & $\ldots$ & $\ldots$ & $\ldots$ & $\ldots$ & $\ldots$ & $\ldots$ & $\ldots$ & $\ldots$ & $\ldots$ & $\ldots$ & 26 \\
\hline HE 1300-2201 & -2.61 & $\ldots$ & $\ldots$ & $\ldots$ & $\ldots$ & $\ldots$ & $\ldots$ & $\ldots$ & $\ldots$ & $\ldots$ & $\ldots$ & $\ldots$ & $\ldots$ & $\ldots$ & $\ldots$ & $\ldots$ & $\ldots$ & $\ldots$ & $\ldots$ & $\ldots$ & $\ldots$ & 26 \\
\hline HE $1305+0007$ & -2.03 & 2.60 & 1.97 & $\ldots$ & $\ldots$ & $\ldots$ & $\ldots$ & $\ldots$ & $\ldots$ & $\ldots$ & $\ldots$ & $\ldots$ & $\ldots$ & $\ldots$ & $\ldots$ & $\ldots$ & $\ldots$ & 2.37 & $\ldots$ & $\ldots$ & $\ldots$ & 30 \\
\hline
\end{tabular}


Table B.4. continued.

\begin{tabular}{|c|c|c|c|c|c|c|c|c|c|c|c|c|c|c|c|c|c|c|c|c|c|c|}
\hline Star & {$[\mathrm{Fe} / \mathrm{H}]$} & $\mathrm{Sm}$ & $\mathrm{Eu}$ & Gd & $\mathrm{Tb}$ & Dy & Ho & $\mathrm{Er}$ & $\mathrm{Tm}$ & $\mathrm{Yb}$ & $\mathrm{Lu}$ & Hf & $\mathrm{W}$ & Os & $\mathrm{Ir}$ & $\mathrm{Pt}$ & $\mathrm{Au}$ & $\mathrm{Pb}$ & $\mathrm{Bi}$ & Th & $\mathrm{U}$ & Ref. \\
\hline HE 1305-0331 & -3.26 & $\ldots$ & $\ldots$ & $\ldots$ & $\ldots$ & $\ldots$ & $\ldots$ & $\ldots$ & $\ldots$ & $\ldots$ & $\ldots$ & $\ldots$ & $\ldots$ & $\ldots$ & $\ldots$ & $\ldots$ & $\ldots$ & $\ldots$ & $\ldots$ & $\ldots$ & $\ldots$ & 26 \\
\hline HE 1319-1935 & -1.74 & $\ldots$ & $\ldots$ & $\ldots$ & $\ldots$ & $\ldots$ & $\ldots$ & $\ldots$ & $\ldots$ & $\ldots$ & $\ldots$ & $\ldots$ & $\ldots$ & $\ldots$ & $\ldots$ & $\ldots$ & $\ldots$ & $\ldots$ & $\ldots$ & $\ldots$ & $\ldots$ & 37 \\
\hline HE $1327-2326$ & -5.66 & $\ldots$ & $\ldots$ & $\ldots$ & $\ldots$ & $\ldots$ & $\ldots$ & $\ldots$ & $\ldots$ & $\ldots$ & $\ldots$ & $\ldots$ & $\ldots$ & $\ldots$ & $\ldots$ & $\ldots$ & $\ldots$ & $\ldots$ & $\ldots$ & $\ldots$ & $\ldots$ & 35 \\
\hline HE $1327-2326$ & -5.96 & $\ldots$ & $<4.64$ & $\ldots$ & $\ldots$ & $\ldots$ & $\ldots$ & $\ldots$ & $\ldots$ & $\ldots$ & $\ldots$ & $\ldots$ & $\ldots$ & $\ldots$ & $\ldots$ & $\ldots$ & $\ldots$ & $\ldots$ & $\ldots$ & $\ldots$ & $\ldots$ & 39 \\
\hline HE $1327-2326$ & -5.96 & $\ldots$ & $<4.64$ & $\ldots$ & $\ldots$ & $\ldots$ & $\ldots$ & $\ldots$ & $\ldots$ & $\ldots$ & $\ldots$ & $\ldots$ & $\ldots$ & $\ldots$ & $\ldots$ & $\ldots$ & $\ldots$ & $\ldots$ & $\ldots$ & $\ldots$ & $\ldots$ & adopted \\
\hline HE 1330-0354 & -2.29 & $\ldots$ & $\ldots$ & $\ldots$ & $\ldots$ & $\ldots$ & $\ldots$ & $\ldots$ & $\ldots$ & $\ldots$ & $\ldots$ & $\ldots$ & $\ldots$ & $\ldots$ & $\ldots$ & $\ldots$ & $\ldots$ & $\ldots$ & $\ldots$ & $\ldots$ & $\ldots$ & 26 \\
\hline HE 1351-1049 & -3.46 & $\ldots$ & $\ldots$ & $\ldots$ & $\ldots$ & $\ldots$ & $\ldots$ & $\ldots$ & $\ldots$ & $\ldots$ & $\ldots$ & $\ldots$ & $\ldots$ & $\ldots$ & $\ldots$ & $\ldots$ & $\ldots$ & $\ldots$ & $\ldots$ & $\ldots$ & $\ldots$ & 26 \\
\hline HE 1410-0004 & -3.02 & $\ldots$ & $<2.40$ & $\ldots$ & $\ldots$ & $\ldots$ & $\ldots$ & $\ldots$ & $\ldots$ & $\ldots$ & $\ldots$ & $\ldots$ & $\ldots$ & $\ldots$ & $\ldots$ & $\ldots$ & $\ldots$ & $<3.17$ & $\ldots$ & $\ldots$ & $\ldots$ & 31 \\
\hline HE $1410+0213$ & -2.16 & $\ldots$ & $\ldots$ & $\ldots$ & $\ldots$ & $\ldots$ & $\ldots$ & $\ldots$ & $\ldots$ & $\ldots$ & $\ldots$ & $\ldots$ & $\ldots$ & $\ldots$ & $\ldots$ & $\ldots$ & $\ldots$ & $\ldots$ & $\ldots$ & $\ldots$ & $\ldots$ & 31 \\
\hline HE $1410+0213$ & -2.52 & $<0.60$ & $\ldots$ & $\ldots$ & $\ldots$ & $\ldots$ & $\ldots$ & $\ldots$ & $\ldots$ & $\ldots$ & $\ldots$ & $\ldots$ & $\ldots$ & $\ldots$ & $\ldots$ & $\ldots$ & $\ldots$ & $<1.52$ & $\ldots$ & $\ldots$ & $\ldots$ & 46 \\
\hline HE $1410+0213$ & -2.34 & $<0.60$ & $\ldots$ & $\ldots$ & $\ldots$ & $\ldots$ & $\ldots$ & $\ldots$ & $\ldots$ & $\ldots$ & $\ldots$ & $\ldots$ & $\ldots$ & $\ldots$ & $\ldots$ & $\ldots$ & $\ldots$ & $<1.52$ & $\ldots$ & $\ldots$ & $\ldots$ & adopted \\
\hline HE 1413-1954 & -3.22 & $\ldots$ & $\ldots$ & $\ldots$ & $\ldots$ & $\ldots$ & $\ldots$ & $\ldots$ & $\ldots$ & $\ldots$ & $\ldots$ & $\ldots$ & $\ldots$ & $\ldots$ & $\ldots$ & $\ldots$ & $\ldots$ & $\ldots$ & $\ldots$ & $\ldots$ & $\ldots$ & 26 \\
\hline HE 1419-1324 & -3.05 & 0.53 & $\ldots$ & $\ldots$ & $\ldots$ & $\ldots$ & $\ldots$ & $\ldots$ & $\ldots$ & $\ldots$ & $\ldots$ & $\ldots$ & $\ldots$ & $\ldots$ & $\ldots$ & $\ldots$ & $\ldots$ & 2.15 & $\ldots$ & $\ldots$ & $\ldots$ & 46 \\
\hline HE 1429-0551 & -2.47 & $\ldots$ & $\ldots$ & $\ldots$ & $\ldots$ & $\ldots$ & $\ldots$ & $\ldots$ & $\ldots$ & $\ldots$ & $\ldots$ & $\ldots$ & $\ldots$ & $\ldots$ & $\ldots$ & $\ldots$ & $\ldots$ & $\ldots$ & $\ldots$ & $\ldots$ & $\ldots$ & 37 \\
\hline HE 1430-1123 & -2.71 & $\ldots$ & $\ldots$ & $\ldots$ & $\ldots$ & $\ldots$ & $\ldots$ & $\ldots$ & $\ldots$ & $\ldots$ & $\ldots$ & $\ldots$ & $\ldots$ & $\ldots$ & $\ldots$ & $\ldots$ & $\ldots$ & $\ldots$ & $\ldots$ & $\ldots$ & $\ldots$ & 26 \\
\hline HE 1434-1442 & -2.39 & $\ldots$ & $\ldots$ & $\ldots$ & $\ldots$ & $\ldots$ & $\ldots$ & $\ldots$ & $\ldots$ & $\ldots$ & $\ldots$ & $\ldots$ & $\ldots$ & $\ldots$ & $\ldots$ & $\ldots$ & $\ldots$ & 2.18 & $\ldots$ & $\ldots$ & $\ldots$ & 31 \\
\hline HE $1443+0113$ & -2.07 & $\ldots$ & $\ldots$ & $\ldots$ & $\ldots$ & $\ldots$ & $\ldots$ & $\ldots$ & $\ldots$ & $\ldots$ & $\ldots$ & $\ldots$ & $\ldots$ & $\ldots$ & $\ldots$ & $\ldots$ & $\ldots$ & $\ldots$ & $\ldots$ & $\ldots$ & $\ldots$ & 31 \\
\hline HE $1447+0102$ & -2.47 & $\ldots$ & $\ldots$ & $\ldots$ & $\ldots$ & $\ldots$ & $\ldots$ & $\ldots$ & $\ldots$ & $\ldots$ & $\ldots$ & $\ldots$ & $\ldots$ & $\ldots$ & $\ldots$ & $\ldots$ & $\ldots$ & $\ldots$ & $\ldots$ & $\ldots$ & $\ldots$ & 37 \\
\hline HE 1509-0806 & -2.91 & $\ldots$ & $<0.93$ & $\ldots$ & $\ldots$ & $\ldots$ & $\ldots$ & $\ldots$ & $\ldots$ & $\ldots$ & $\ldots$ & $\ldots$ & $\ldots$ & $\ldots$ & $\ldots$ & $\ldots$ & $\ldots$ & 2.61 & $\ldots$ & $\ldots$ & $\ldots$ & 31 \\
\hline HE 1523-1155 & -2.15 & $\ldots$ & $\ldots$ & $\ldots$ & $\ldots$ & $\ldots$ & $\ldots$ & $\ldots$ & $\ldots$ & $\ldots$ & $\ldots$ & $\ldots$ & $\ldots$ & $\ldots$ & $\ldots$ & $\ldots$ & $\ldots$ & $\ldots$ & $\ldots$ & $\ldots$ & $\ldots$ & 37 \\
\hline HE 1528-0409 & -2.61 & $\ldots$ & $\ldots$ & $\ldots$ & $\ldots$ & $\ldots$ & $\ldots$ & $\ldots$ & $\ldots$ & $\ldots$ & $\ldots$ & $\ldots$ & $\ldots$ & $\ldots$ & $\ldots$ & $\ldots$ & $\ldots$ & $\ldots$ & $\ldots$ & $\ldots$ & $\ldots$ & 37 \\
\hline HE 2148-1247 & -2.30 & 1.99 & 1.98 & 2.23 & $\ldots$ & 2.16 & $\ldots$ & $\ldots$ & $\ldots$ & $\ldots$ & $\ldots$ & $\ldots$ & $\ldots$ & $\ldots$ & $\ldots$ & $\ldots$ & $\ldots$ & 3.12 & $\ldots$ & 1.73 & $\ldots$ & 19 \\
\hline HE $2150-0825$ & -1.98 & $\ldots$ & $\ldots$ & $\ldots$ & $\ldots$ & $\ldots$ & $\ldots$ & $\ldots$ & $\ldots$ & $\ldots$ & $\ldots$ & $\ldots$ & $\ldots$ & $\ldots$ & $\ldots$ & $\ldots$ & $\ldots$ & $\ldots$ & $\ldots$ & $\ldots$ & $\ldots$ & 26 \\
\hline HE 2158-0348 & -2.70 & $<2.40$ & 0.80 & $\ldots$ & $\ldots$ & $\ldots$ & $\ldots$ & $\ldots$ & $\ldots$ & $\ldots$ & $\ldots$ & $\ldots$ & $\ldots$ & $\ldots$ & $\ldots$ & $\ldots$ & $\ldots$ & 2.60 & $\ldots$ & $\ldots$ & $\ldots$ & 31 \\
\hline HE 2221-0453 & -2.22 & $\ldots$ & $\ldots$ & $\ldots$ & $\ldots$ & $\ldots$ & $\ldots$ & $\ldots$ & $\ldots$ & $\ldots$ & $\ldots$ & $\ldots$ & $\ldots$ & $\ldots$ & $\ldots$ & $\ldots$ & $\ldots$ & $\ldots$ & $\ldots$ & $\ldots$ & $\ldots$ & 37 \\
\hline HE 2228-0706 & -2.41 & $\ldots$ & $\ldots$ & $\ldots$ & $\ldots$ & $\ldots$ & $\ldots$ & $\ldots$ & $\ldots$ & $\ldots$ & $\ldots$ & $\ldots$ & $\ldots$ & $\ldots$ & $\ldots$ & $\ldots$ & $\ldots$ & $\ldots$ & $\ldots$ & $\ldots$ & $\ldots$ & 37 \\
\hline HE 2232-0603 & -1.85 & $\ldots$ & $\ldots$ & $\ldots$ & $\ldots$ & $\ldots$ & $\ldots$ & $\ldots$ & $\ldots$ & $\ldots$ & $\ldots$ & $\ldots$ & $\ldots$ & $\ldots$ & $\ldots$ & $\ldots$ & $\ldots$ & 1.55 & $\ldots$ & $\ldots$ & $\ldots$ & 31 \\
\hline HE 2240-0412 & -2.20 & $\ldots$ & $\ldots$ & $\ldots$ & $\ldots$ & $\ldots$ & $\ldots$ & $\ldots$ & $\ldots$ & $\ldots$ & $\ldots$ & $\ldots$ & $\ldots$ & $\ldots$ & $\ldots$ & $\ldots$ & $\ldots$ & $\ldots$ & $\ldots$ & $\ldots$ & $\ldots$ & 26 \\
\hline HE 2330-0555 & -2.78 & $\ldots$ & $\ldots$ & $\ldots$ & $\ldots$ & $\ldots$ & $\ldots$ & $\ldots$ & $\ldots$ & $\ldots$ & $\ldots$ & $\ldots$ & $\ldots$ & $\ldots$ & $\ldots$ & $\ldots$ & $\ldots$ & $\ldots$ & $\ldots$ & $\ldots$ & $\ldots$ & 37 \\
\hline LP 625-44 & -2.68 & 2.19 & 1.75 & $\ldots$ & $\ldots$ & 1.70 & $\ldots$ & $\ldots$ & $\ldots$ & $\ldots$ & $\ldots$ & $\ldots$ & $\ldots$ & $\ldots$ & $\ldots$ & $\ldots$ & $\ldots$ & $\ldots$ & $\ldots$ & $\ldots$ & $\ldots$ & 3 \\
\hline LP 625-44 & -2.70 & $\ldots$ & 1.76 & $\ldots$ & $\ldots$ & 1.30 & $\ldots$ & $\ldots$ & $\ldots$ & 1.9 & $\ldots$ & 2.39 & $\ldots$ & $<1.87$ & $<1.49$ & $\ldots$ & $\ldots$ & 2.67 & $\ldots$ & $\ldots$ & $\ldots$ & 34 \\
\hline LP 625-44 & -2.71 & 2.20 & 1.97 & 2.31 & $\ldots$ & 1.98 & $\ldots$ & 2.04 & 1.96 & $\ldots$ & $\ldots$ & 2.76 & $\ldots$ & $\ldots$ & $\ldots$ & $\ldots$ & $\ldots$ & 2.65 & $\ldots$ & $\ldots$ & $\ldots$ & 4 \\
\hline LP 625-44 & -2.71 & 2.21 & 1.97 & 2.31 & $\ldots$ & 1.64 & $\ldots$ & 2.04 & 1.96 & $\ldots$ & $\ldots$ & 2.76 & $\ldots$ & $\ldots$ & $\ldots$ & $\ldots$ & $\ldots$ & 2.55 & $\ldots$ & $\ldots$ & $\ldots$ & 9 \\
\hline LP 625-44 & -2.70 & 2.21 & 1.76 & 2.31 & $\ldots$ & 1.30 & $\ldots$ & 2.04 & 1.96 & 1.9 & $\ldots$ & 2.39 & $\ldots$ & $<1.87$ & $<1.49$ & $\ldots$ & $\ldots$ & 2.67 & $\ldots$ & $\ldots$ & $\ldots$ & adopted \\
\hline SDSS 0036-10 & -2.42 & $\ldots$ & $\ldots$ & $\ldots$ & $\ldots$ & $\ldots$ & $\ldots$ & $\ldots$ & $\ldots$ & $\ldots$ & $\ldots$ & $\ldots$ & $\ldots$ & $\ldots$ & $\ldots$ & $\ldots$ & $\ldots$ & $<2.72$ & $\ldots$ & $\ldots$ & $\ldots$ & 41 \\
\hline SDSS 0126+06 & -3.11 & $\ldots$ & $\ldots$ & $\ldots$ & $\ldots$ & $\ldots$ & $\ldots$ & $\ldots$ & $\ldots$ & $\ldots$ & $\ldots$ & $\ldots$ & $\ldots$ & $\ldots$ & $\ldots$ & $\ldots$ & $\ldots$ & 3.41 & $\ldots$ & $\ldots$ & $\ldots$ & 41 \\
\hline SDSS 0817+26 & -3.16 & $\ldots$ & $\ldots$ & $\ldots$ & $\ldots$ & $\ldots$ & $\ldots$ & $\ldots$ & $\ldots$ & $\ldots$ & $\ldots$ & $\ldots$ & $\ldots$ & $\ldots$ & $\ldots$ & $\ldots$ & $\ldots$ & $\ldots$ & $\ldots$ & $\ldots$ & $\ldots$ & 41 \\
\hline SDSS 0912+02 & -2.5 & 2.60 & 1.20 & 2.80 & 2.64 & 1.96 & $\ldots$ & 2.03 & $\ldots$ & $\ldots$ & $\ldots$ & 2.72 & $\ldots$ & $\ldots$ & $\ldots$ & $\ldots$ & $\ldots$ & 2.33 & $\ldots$ & $\ldots$ & $\ldots$ & 45 \\
\hline SDSS 0924+40 & -2.55 & $\ldots$ & $\ldots$ & $\ldots$ & $\ldots$ & $\ldots$ & $\ldots$ & $\ldots$ & $\ldots$ & $\ldots$ & $\ldots$ & $\ldots$ & $\ldots$ & $\ldots$ & $\ldots$ & $\ldots$ & $\ldots$ & 3.01 & $\ldots$ & $\ldots$ & $\ldots$ & 41 \\
\hline SDSS $1036+12$ & -3.2 & 2.92 & 1.26 & 2.62 & 2.90 & 2.46 & $\ldots$ & 2.86 & 2.78 & $\ldots$ & $\ldots$ & 2.35 & $\ldots$ & 2.11 & 2.00 & $\ldots$ & $\ldots$ & $\ldots$ & $\ldots$ & $\ldots$ & $\ldots$ & 45 \\
\hline SDSS 1349-02 & -3.0 & 2.35 & 1.62 & 2.50 & 2.69 & 2.39 & $\ldots$ & 2.73 & $\ldots$ & $\ldots$ & $\ldots$ & 3.14 & $\ldots$ & $\ldots$ & $\ldots$ & $\ldots$ & $\ldots$ & 3.09 & $\ldots$ & $\ldots$ & $\ldots$ & 45 \\
\hline SDSS $1707+58$ & -2.49 & $\ldots$ & $\ldots$ & $\ldots$ & $\ldots$ & $\ldots$ & $\ldots$ & $\ldots$ & $\ldots$ & $\ldots$ & $\ldots$ & $\ldots$ & $\ldots$ & $\ldots$ & $\ldots$ & $\ldots$ & $\ldots$ & $<3.69$ & $\ldots$ & $\ldots$ & $\ldots$ & 41 \\
\hline SDSS $2047+00$ & -2.05 & $\ldots$ & $\ldots$ & $\ldots$ & $\ldots$ & $\ldots$ & $\ldots$ & $\ldots$ & $\ldots$ & $\cdots$ & $\cdots$ & $\ldots$ & $\ldots$ & $\ldots$ & $\ldots$ & $\cdots$ & $\ldots$ & $\ldots$ & $\ldots$ & $\ldots$ & $\cdots$ & 41 \\
\hline
\end{tabular}

Notes. References are the same as in Table B.1. See notes in Table B.1 for different IDs. 